SAND96-2030 • UC-814

Unlimited Release

Printed September 1996

Yucca Mountain Site Charaçterization Project

\title{
Geology of the USW SD-9 Drill Hole, Yucca Mountain, Nevada
}

\author{
AECEVED \\ DEC O 9 1996 \\ OSTI
}

\section{A. Engstrom, Christopher A. Rautman}

Prepared by

Sandia National Laboratories

Albuquerque, New Mexico 87185 and Livermore, California 94550

for the United States Department of Energy

under Contract DE-AC04-94AL85000

Approved for public release, istribution is unlimited.

10 a
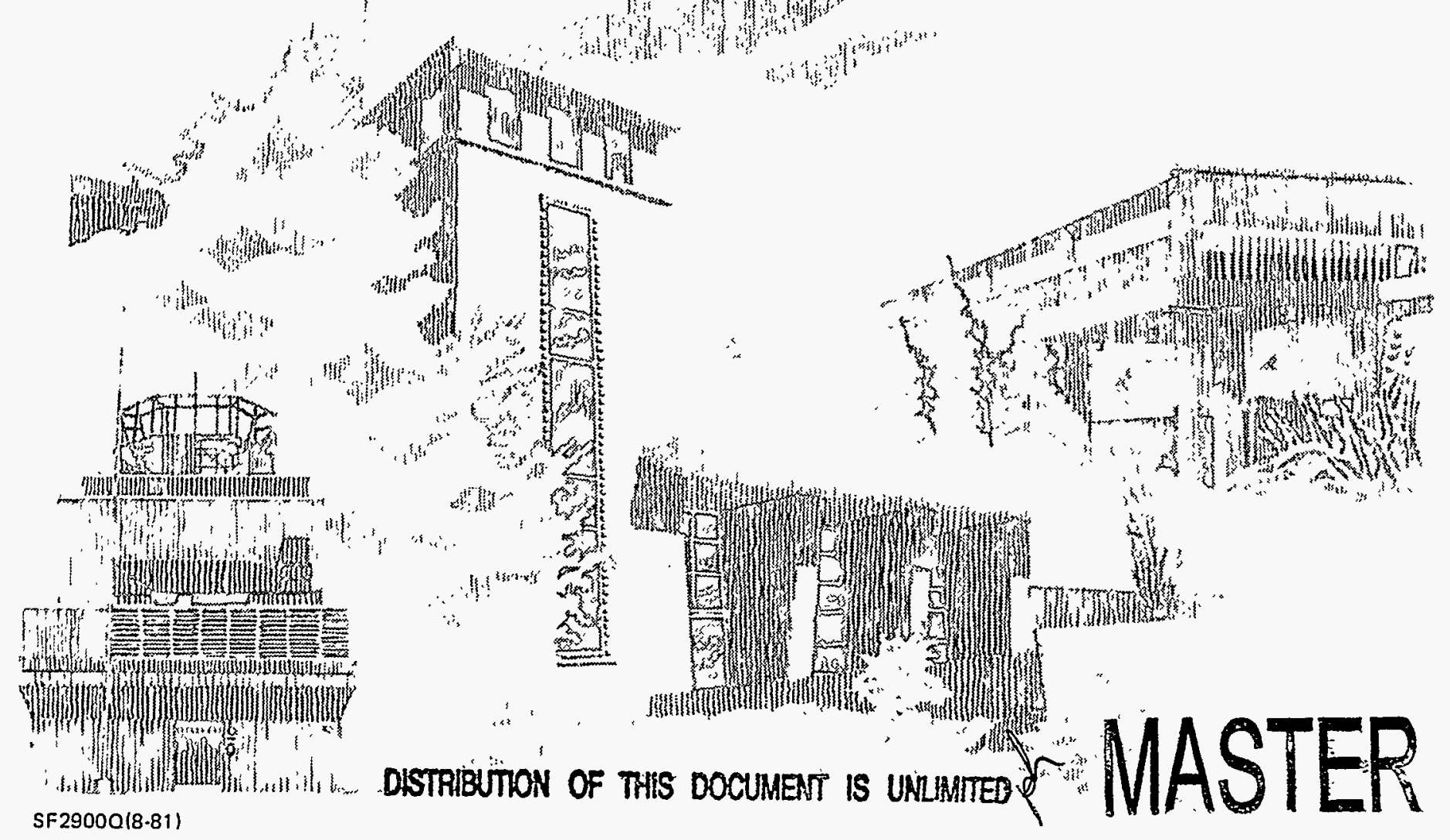
"Prepared by Yucca Mountain Site Characterization Project (YMSCP) participants as part of the Civilian Radioactive Waste Management Program (CRWM). The YMSCP is managed by the Yucca Mountain Project Office of the U.S. Department of Energy, DOE Field Office, Nevada (DOE/NV). YMSCP work is sponsored by the Office of Geologic Repositories (OGR) of the DOE Office of Civilian Radioactive Waste Management (OCRWM)."

Issued by Sandia National Laboratories, operated for the United States Department of Energy by Sandia Corporation.

NOTICE: This report was prepared as an account of work sponsored by an agency of the United States Government. Neither the United States Government nor any agency thereof, nor any of their employees, nor any of their contractors, subcontractors, or their employees, makes any warranty, express or implied, or assumes any legal liability or responsibility for the accuracy, completeness, or usefulness of any information, apparatus, product, or process disclosed, or represents that its use would not infringe privately owned rights. Reference herein to any specific commercial product, process, or service by trade name, trademark, manufacturer, or otherwise, does not necessarily constitute or imply its endorsement, recommendation, or favoring by the United States Government, any agency thereof or any of their contractors or subcontractors. The views and opinions expressed herein do not necessarily state or reflect those of the United States Government, any agency thereof or any of their contractors.

Printed in the United States of America. This report has been reproduced directly from the best available copy.

Available to DOE and DOE contractors from

Office of Scientific and Technical Information

PO Box 62

Oak Ridge, TN 37831

Prices available from (615) 576-8401, FTS 626-8401

Available to the public from

National Technical Information Service

US Department of Commerce

5285 Port Royal Rd

Springfield, VA 22161

NTIS price codes

Printed copy: A08

Microfiche copy: A01 
within and among the major formational-level stratigraphic units. Nonwelded intervals in general exhibit higher recoveries and more intact (higher) RQD values than welded intervals. The most intact, highest$\because$ RQD materials encountered within the Topopah Spring belong to the lower $33.3 \mathrm{ft}(10.15 \mathrm{~m})$ of the middle nonlithophysal zone. Estimation of lithophysal cavity abundances is complicated by the existence of cavities much larger than the core diameter; drilling through intervals of these large cavities produced extensive zones of "lost" core and rubble.

This report includes quantitative data for the framework material properties of porosity, bulk and particle density, and saturated hydraulic conductivity. Graphical analysis of variations in these laboratory hydrologic properties indicates first-order control of material properties by the degree of welding and the presence of zeolite minerals. Many major lithostratigraphic contacts are not well expressed in the materialproperty profiles; contacts of material-property units are related more to changes in the intensity of welding. Approximate in-situ saturation data of samples preserved immediately upon recovery from the hole are included in the data tabulation.

Geophysical data have been obtained for the upper approximately $1500 \mathrm{ft}(450 \mathrm{~m})$ of the USW SD-9 drill hole; the lower part of the hole below the Topopah Spring Tuff has not been logged. Geophysical logs include density, gamma-ray, epithermal-neutron porosity, electrical-resistivity, and caliper profiles down to the base of the Topopah Spring Tuff. The bulk-density log provides the most lithologic information, and many of the lithologic subdivisions of the Paintbrush Group tuffs can be tied to distinctive changes in the density trace. Discrimination of welded from nonwelded rock types and of lithophysal zones and nonlithophysal zones is immediately apparent in the density log. Material-property units identified using geophysical logs do not correspond in detail to the broader, genetic lithostratigraphic unit boundaries.

\section{Acknowledgments}

This work was performed for the U.S. Department of Energy, Office of Civilian Radioactive Waste Management, Yucca Mountain Site Characterization Project Office under contract EA9012M5X. Scientific investigations involving the Systematic Drilling Program are conducted under the descriptions of work contained in the Site Characterization Plan (DOE, 1988) and in Study Plan 8.3.1.4.3.1 (Rautman, 1993); the work-breakdown structure element is 1.2.3.2.2.2.1. The planning document that directed this work activity is WA-0301; prior to the effective date of WA-0301, work activities for this WBS element were conducted under WA-0014. The information and data documented in this report was conducted under a fully qualified quality assurance program. Full details associated with all reported data may be located in the Yucca Mountain Site Characterization Project records using the data-tracking numbers (DTNs) provided in the relevant sections of this report. 


\title{
Geology of the USW SD-9 Drill Hole, Yucca Mountain, Nevada
}

\author{
Dale A. Engstrom \\ Spectra Research Institute \\ Albuquerque, New Mexico 87106 \\ Christopher A. Rautman \\ Geohydrology Department \\ Sandia National Laboratories \\ Albuquerque, New Mexico 87185
}

\begin{abstract}
Drill hole USW SD-9 is one of several holes drilled under Site Characterization Plan Study 8.3.1.4.3.1, also known as the "Systematic Drilling Program," as part of the U.S. Department of Energy characterization program at Yucca Mountain, Nevada, which has been proposed as the potential location of a repository for high-level nuclear waste. The SD-9 drill hole is located in the northern part of the potential repository area, immediately to the west of the Main Test Level drift of Exploratory Studies Facility and south of the North Ramp decline. Drill hole USW SD-9 is $2223.1 \mathrm{ft}(677.57 \mathrm{~m})$ deep, and the core recovered essentially complete sections of ash-flow tuffs belonging to the Yucca Mountain, Pah Canyon, and Topopah Spring Tuffs of the Miocene Paintbrush Group. The hole cored the entire Calico Hills Formation, which underlies the Paintbrush Group, and all but the lowermost part of the Prow Pass Tuff of the Crater Flat Group.
\end{abstract}

The drill hole was collared low in the welded portion of the Tiva Canyon Tuff; only 38.7 (11.8 m) of this formation was recovered. The Yucca Mountain Tuff is approximately 45-ft (13.7-m) thick, and the interior portion of this ash flow is partially welded. The Yucca Mountain Tuff thins to extinction southward. The Pah Canyon Tuff is $69.4 \mathrm{ft}(21.15 \mathrm{~m})$ thick and is completely nonwelded in this drill hole. The Topopah Spring Tuff consists of $1211.5 \mathrm{ft}(369.25 \mathrm{~m})$ of generally densely welded material; this is one of the thickest known sections of welded Topopah Spring Tuff at or near Yucca Mountain. Lithophysae are well developed locally within the parts of the Topopah Spring, and large lithophysal cavities up to several feet (many tenths of a meter) in diameter are present throughout roughly the lower two-thirds of the unit. This somewhat anomalous occurrence of very large lithophysal cavities, which is in addition to the better known presence of zones containing smaller, inch-scale (cm-scale) lithophysae within the Topopah Spring, may be related genetically to the greater thickness of the unit at this geographic location. The Calico Hills Formation in drill hole SD-9 consists of $341 \mathrm{ft}(103.87 \mathrm{~m})$ of nonwelded and mostly zeolitized tuffaceous materials. The hole cored $402.4 \mathrm{ft}(122.65 \mathrm{~m})$ of rocks belonging to the ash-flow sequences of the Prow Pass Tuff. The drill hole was stopped short of the base of the lowermost known ash-flow unit of the Prow Pass.

Quantitative and semiquantitative data are included in this report for core recovery, rock-quality designation (RQD), lithophysal cavity abundance, and fracturing. These data are spatially variable, both 


\section{Contents}

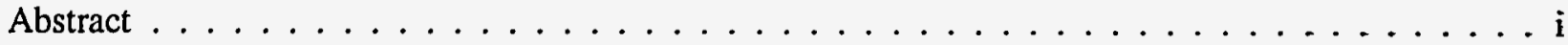

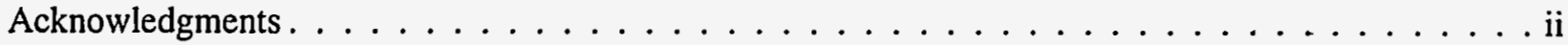

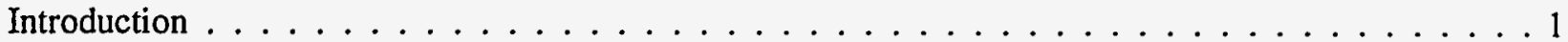

Purpose of the

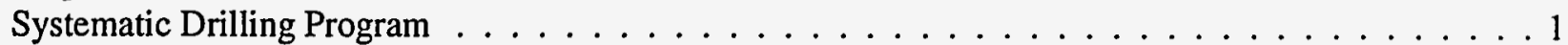

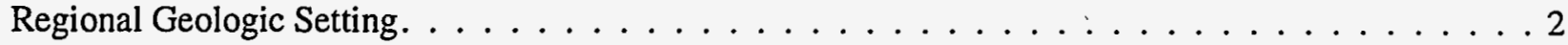

Volcanic Stratigraphy . . . . . . . . . . . . . . . . . . . 2

Petrogenesis and Zonation of Paintbrush Group Tuffs . . . . . . . . . . . . . . . . . 3

Subdivisions of the Calico Hills Formation and Prow Pass Tuff (Crater Flat Group) . . . . . . . 5

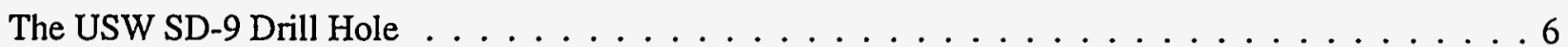

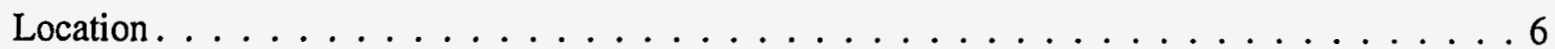

Drilling History . . . . . . . . . . . . . . . . . . .

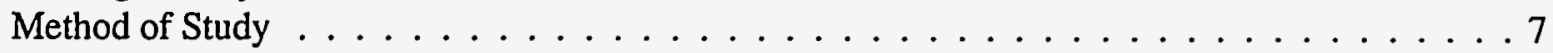

Geologic Logging and Core Description . . . . . . . . . . . . 7

Laboratory Material Properties . . . . . . . . . . . . . . . . . 8

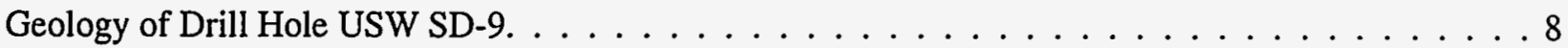

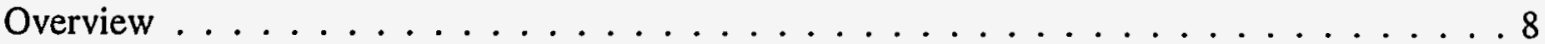

Thermal/Mechanical Units . . . . . . . . . . . . . . . . . . . . 11

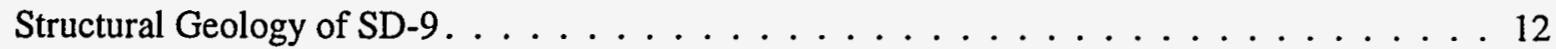

Lithophysal Zones. . . . . . . . . . . . . . . . . . . . . . 12

Rock Quality Considerations . . . . . . . . . . . . . . . . . . . . . . . 14

Core Recovery . . . . . . . . . . . . . . . . . . . . . . . . . 14

RQD (Rock Quality Designation) . . . . . . . . . . . . . . . . . . . 16

Measured Lithophysal Cavity Information . . . . . . . . . . . . . 18

Fracture Information . . . . . . . . . . . . . . . . . . . 19

Framework Hydrologic Properties . . . . . . . . . . . . . . . . 23

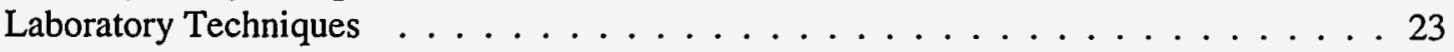

Material-Properties Data . . . . . . . . . . . . . . . . . 25

Geophysical $\log$ Data $\ldots \ldots \ldots \ldots \ldots$

Density $\log$ Response . . . . . . . . . . . . . . . . . . . . . 28

Gamma-Ray $\log$ Response . . . . . . . . . . . . . . . . . . . . . 30

Epithermal Neutron Porosity Log Response . . . . . . . . . . . . . . . . . . . 30

Dual-Induction $\log$ Response $\ldots \ldots \ldots \ldots$. . . . . . . . . . . 31

Caliper Log Response . . . . . . . . . . . . . . . . . . . . . . 31

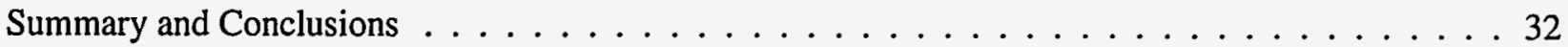

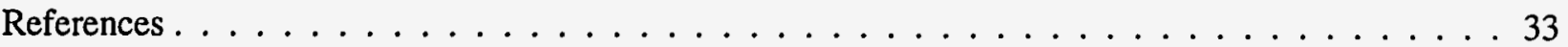

Appendix A: Detailed Lithologic Descriptions . . . . . . . . . . . . . . . 37

Tiva Canyon Tuff . . . . . . . . . . . . . . . . . . . 38

Yucca Mountain Tuff . . . . . . . . . . . . . . . . . . . . . . . 39

Pah Canyon Tuff . . . . . . . . . . . . . . . . . . . . . 39

Topopah Spring Tuff . . . . . . . . . . . . . . . . . 40

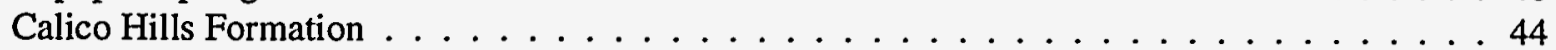

Prow Pass Tuff . . . . . . . . . . . . . . . . . . . . . . 45 
(This page intentionally left blank.) 


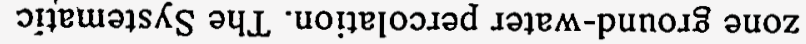

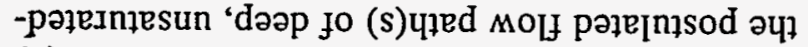

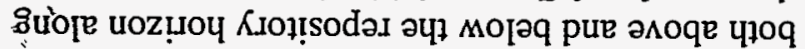

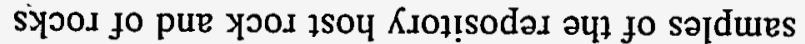
pue suo!̣d!̣osəp әp!̣

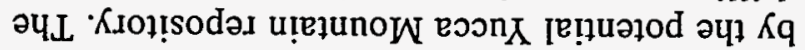

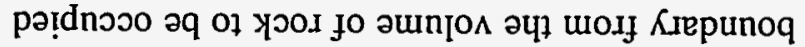

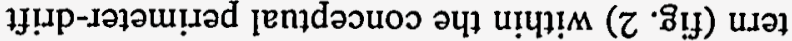

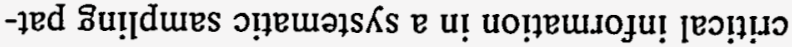

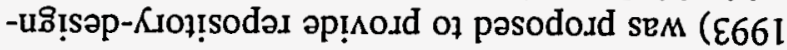

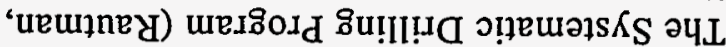

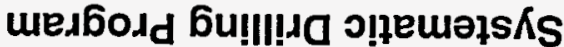 әчt 10 asodind}

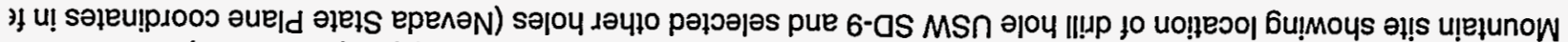

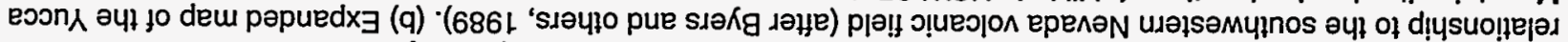

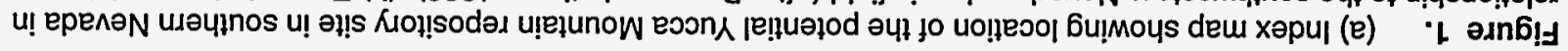

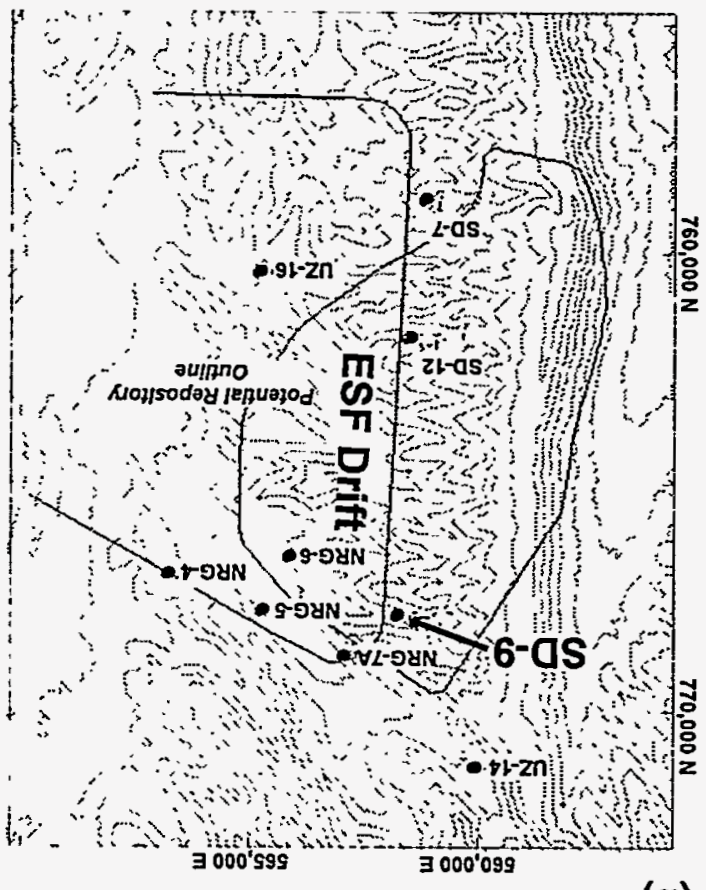

(q)

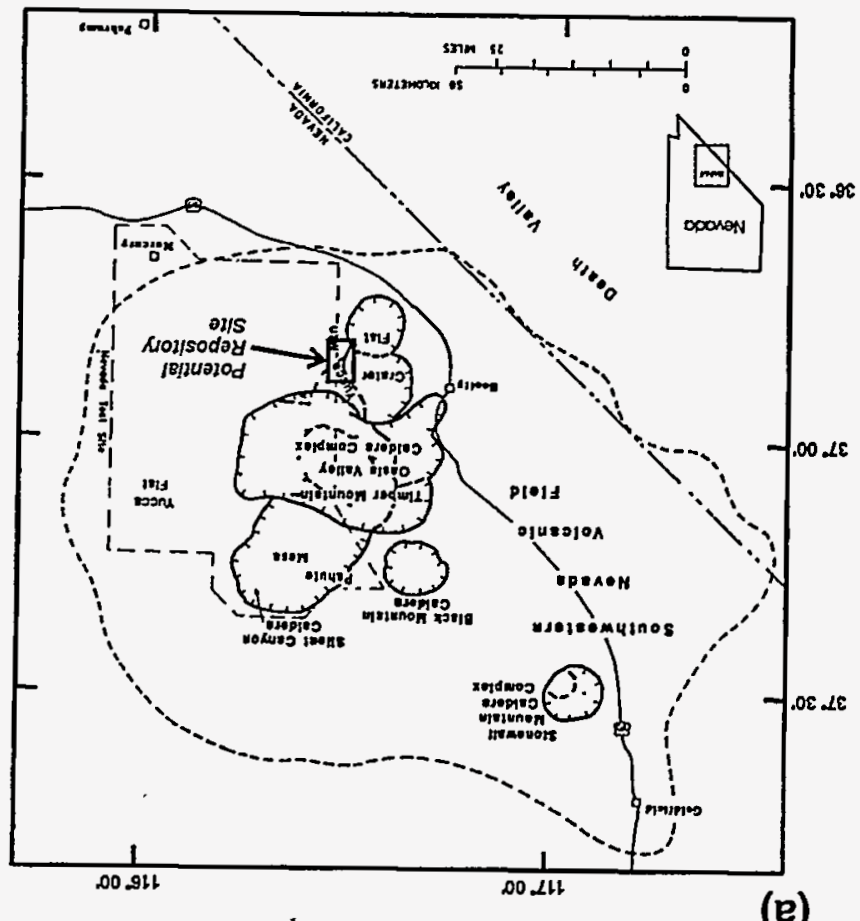

(e)

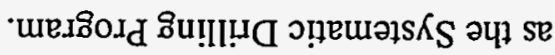

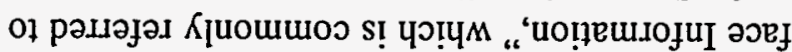

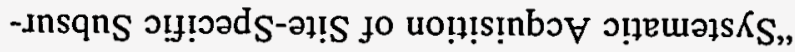

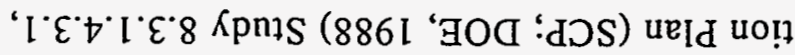

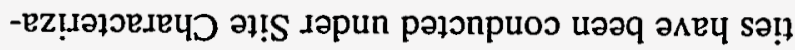

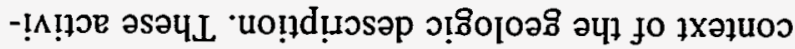

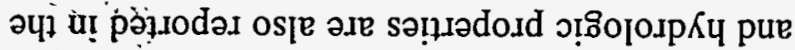

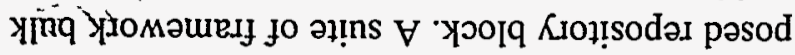

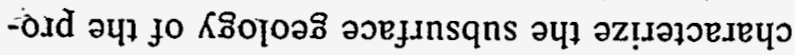

ol วl! u!̣]unow eoon

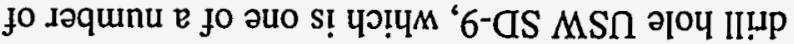

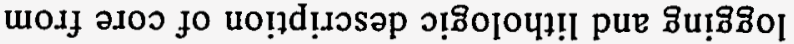

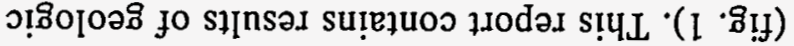

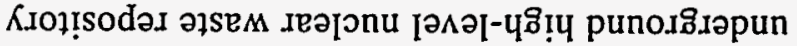

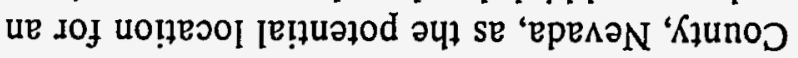

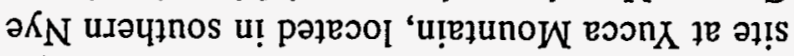

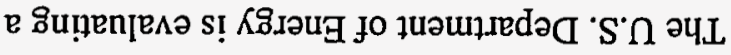

uo!̣onpodịu|

\section{epenəN 'u!̣ęunow eoon $\lambda$

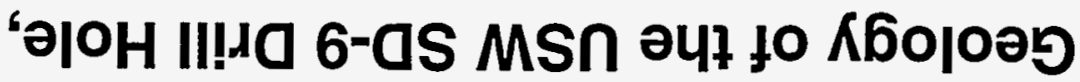


Drilling Program will also provide descriptive information and samples of rocks within the upper portion of the saturated zone, which include zeolitically altered materials that may act to retard radionuclides migrating away from a constructed repository.

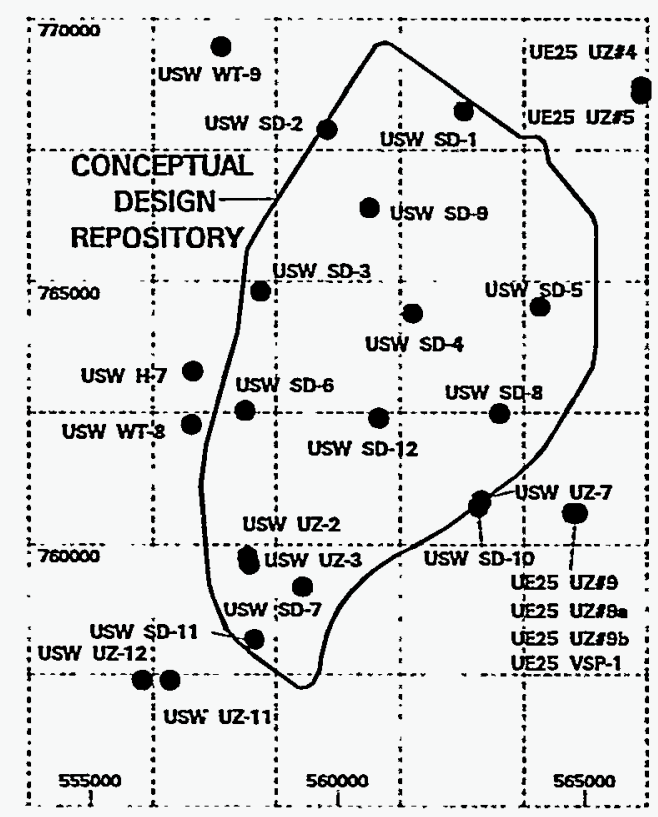

Figure 2. Gridded drilling pattem for the Systematic Drilling Pattern as proposed in Study Plan 8.3.1.4.3.1 (Rautman, 1993).

In addition to descriptive geologic information, core samples provide the raw material for quantitative measurements of thermal, mechanical, hydrologic, and geochemical material properties necessary for numerical modeling and regulatory evaluation of the waste-isolation performance of a potential nuclear-waste repository at Yucca Mountain. A basic set of framework material properties from USW SD-9 is included as part of this report. Other site-characterization studies (DOE, 1988) are also testing samples obtained from the USW SD-9 drill hole. Pore waters extracted from appropriately preserved core specimens and drill cuttings can provide isotopic evidence relevant to the age or residence time and source of the ground water, including data on the infiltration of water containing bomb-pulse isotopes from past atmospheric testing of nuclear weapons. The drill holes themselves provide access to the interior of Yucca
Mountain for geophysical logging, down-hole video examination of the borehole walls, air-permeability testing, water-table monitoring and geochemical sampling, and in-situ instrumentation for monitoring temperatures, gas pressures, and changes in gas chemistry with time.

\section{Regional Geologic Setting}

Yucca Mountain is located within the southern portion of the southwestern Nevada volcanic field (Christiansen and others, 1965 and 1977; Byers and others, 1976, 1989). The southwestern Nevada volcanic field (fig. 1) comprises a thick sequence of widely distributed, 7- to 15-million-year-old silicic volcanic rocks, centered around the Timber Mountain, Oasis Valley, and Silent Canyon caldera complexes (Noble and others, 1968).

Yucca Mountain itself consists of a series of north-trending, eastward-dipping structural blocks that are bounded by mostly west-dipping normal faults (W.J. Carr and others, 1986). These fault blocks are composed principally of thick, welded ash-flow tuff deposits that are separated by thinner, nonwelded ash-flow tuffs, silicic lavas, and tuffaceous sedimentary units, all derived from a caldera complex to the north. Previous drilling at Yucca Mountain has shown that Tertiary volcanic rocks are in excess of $6000 \mathrm{ft}(1829 \mathrm{~m})$ thick in the vicinity of the potential repository (M.D. Carr and others, 1986). Pre-Tertiary rocks underlying Yucca Mountain include thick carbonate and clastic assemblages varying in age from Precambrian to Mississippian. A Mesozoic or Tertiary pluton may lie beneath the Calico Hills to the northeast of the site (Carr, 1984).

\section{Volcanic Stratigraphy}

Yucca Mountain consists of a thick sequence of variably welded and nonwelded ash-flow tuffs intercalated with thinner intervals of bedded (reworked) and air-fall tuffs. The general sequence of stratigraphic units is illustrated in table 1. Surface exposures within the main repository block are formed by the several formations of the Miocene Paintbrush Group. In descending sequence, these are the Tiva Canyon, the Yucca Mountain, Pah Canyon, and Topopah Spring Tuffs (Sawyer and others, 1994). The Tiva Canyon and 


\section{DISCLAIMER}

Portions of this document may be illegible in electronic image products. Images are produced from the best available original document. 
Topopah Spring Tuffs are regionally extensive and generally densely welded. The Yucca Mountain and Pah Canyon Tuffs are generally nonwelded to only moderately welded and they are much less extensive laterally, thinning to extinction toward the south. Each formation-level unit of the Paintbrush Group is separated from its neighbors by thin nonwelded ash-flow tuffs, air-fall tuffs or pumicefall units, and reworked, bedded-tuffaceous deposits. These intervening tuffaceous materials are typically referred to collectively as "bedded tuff" without specific consideration of their actual lithologic character.

The Paintbrush Group in the general vicinity of the proposed repository typically is underlain by a heterogeneous sequence of rhyolitic rocks known as the Calico Hills Formation (Sawyer and others, 1994). Within the repository region itself, the Calico Hills consists of a downward sequence of five nonwelded ash-flow tuffs underlain by bedded-tuff unit and a basal tuffaceous sandstone unit (table 1) (Moyer and Geslin, 1995). Elsewhere in the Yucca Mountain region, the Calico Hills Formation consists of rhyolitic lava flows, ash-flow tuffs, air-fall tuffs, and tuffaceous sediments. Much of the Calico Hills Formation has been zeolitized; vitric tuffs are preserved principally in the southern portion of the Yucca Mountain site.

The Calico Hills Formation is underlain by the Crater Flat Group (Sawyer and others, 1994; Moyer and Geslin, 1995), which comprises, in descending sequence, the Prow Pass, Bullfrog, and Tram Tuffs. Each of these units represents a largevolume ash-flow eruption. Generally, the degree of welding in these units is much less than that exhibited by the tuffs of the Paintbrush Group, and the welded intervals may not be continuous in the subsurface. The greater part of each ash-flow sequence is nonwelded, with welded tuffs constrained to the interior of each unit. The three formation-level units are separated from one another by thin intervals of nonwelded tuff and tuffaceous sediments ("bedded tuff") in a manner similar to that of the Paintbrush Group.

Volcanic units underlying the Crater Flat Group are somewhat poorly known by comparison. They have been encountered at Yucca Mountain only in the deeper drill holes (for example: Spen- gler and others, 1981; Maldonado and Koether, 1983; Scott and Castellanos, 1984; Whitfield and others, 1984). None of these units was encountered in drill hole USW SD-9.

\section{Petrogenesis and Zonation of Paintbrush Group Tuffs}

Early field and petrologic descriptions of the stratigraphic units in the southwestern Nevada volcanic field include work by Lipman and Christiansen (1964) and Lipman and others (1966). In later work more directly focused on the potential Yucca Mountain repository site, the thick, welded intervals of the Tiva Canyon and Topopah Spring Tuffs were subdivided in geologic mapping by Scott and Bonk (1984) into a large number of informally named zones (table 1 ). This early zonation was based on a number of different characteristics, including weathering character and color, in addition to more exposure-independent lithologic characteristics such as phenocryst content, alteration phenomena, and rock type.

More recently, Buesch and others (1996) have redefined the zonation of the Paintbrush Group tuffs. These changes affect principally the thick, welded intervals of the Tiva Canyon and Topopah Spring Tuffs. According to Buesch and others, these two major ash-flow sheets are divided informally into crystal-rich upper members and crystalpoor lower members (table 2). This fundamental change in phenocryst content, which is paralleled by a downward change in chemical composition from quartz latite to rhyolite, originates in the eruption of these ash-flow sequences from a compositionally zoned magma chamber underlying the source calderas (Lipman and others, 1966). More differentiated, rhyolitic magma in the upper portions of the magma chamber erupted first, followed by less-differentiated magmatic material from lower levels as the eruption progressed. A gradational, compositional-transition zone is observed in both the Tiva Canyon and the Topopah Spring Tuffs, which exhibits attributes of both rock types.

Buesch and others further subdivide the crystal-rich and crystal poor members into a number of informal smaller zones and subzones (tables 1,2 ). Some of these zones are based on widespread petrogenetic phenomena, principally cooling pro- 
Table 1: Comparison of several stratigraphic subdivisions of volcanic rocks at Yucca Mountain and encountered on the Yucca Mountain Site Characterization Project. (no scale)

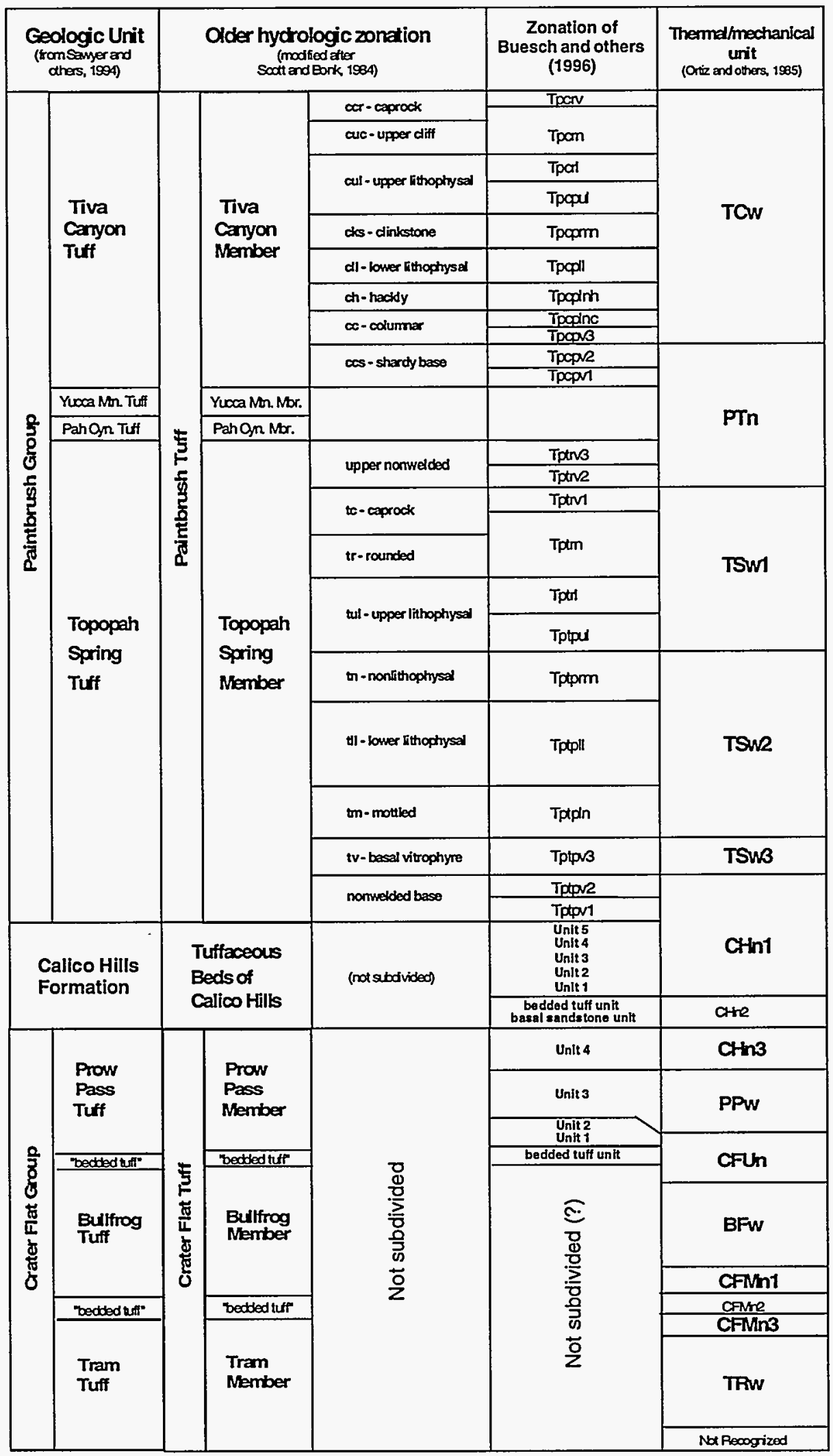


cesses, that affected the ash-flow tuffs during and shortly after deposition. Both the Tiva Canyon and Topopah Spring Tuffs exhibit quenched, nonwelded, vitric zones at the upper and lower margins, where the hot mass of glassy pyroclastic shards cooled rapidly from exposure to ambient air or to the relatively cold, preexisting topography. Welded vitric zones, usually expressed as vitrophyres that compacted, fused, and cooled before devitrification could begin, are found inside the nonwelded vitric zones. The vitrophyre zones are thicker and more laterally extensive at the base of each ash-flow sequence because of the weight of the overlying, progressively accumulating tuff deposit. The major part of both the Tiva Canyon and Topopah Spring Tuffs compacted and cooled slowly because of the insulating effect provided by the quenched and largely nonwelded upper and lower margins of the deposits. The interior parts of each ash-flow sheet thus consist of moderately to densely welded, devitrified tuff.

Buesch and others also define other zones and subzones (table 2) that are related more to alteration phenomena. Residual magmatic gasses exsolved from the compacting and devitrifying mass of glassy shards and these gasses produced vapor-phase alteration consisting principally of microcrystalline, open-space growths of high-temperature silica and feldspar minerals. These phases are distinct from the more "primary" assemblages of minerals resulting from devitrification of the originally glassy mass of shards. Locally, the vapor pressure of the exsolving gas was sufficient to inflate secondary "bubbles," known as lithophysal cavities, along crudely horizontal horizons where internal pressure exceeded the weight of the overlying column of compacting tuff. These lithophysal cavities are themselves rimmed by vapor-phase alteration minerals, and the alteration may extend some distance into the groundmass surrounding the cavity. The resulting, alternating lithophysae-bearing and non-lithophysae-bearing intervals figure prominently into the zonation of Buesch and others (table 2). Additional factors, such as presence and quantity of pumice, foreign lithic clasts, presence of spherulites, and fracturing habit, also have been used to define some of the subzones shown in table 2 .
The thin, tabular nature of a cooling and compacting ash-flow sheet forces most of the thermal and pressure gradients that cause alteration to be oriented essentially normal to the long dimensions of the deposit. Thus, the alteration phenomena of vapor-phase altered zones, intervals of lithophysal cavity development, and zones of strong, near-vertical cooling joint development tend to be subhorizontal and stratiform. However, because these features are the result of secondary alteration phenomena, they can-and do-cross-cut "primary" stratification features such as the crystal-rich/crystal-poor transition.

\section{Subdivisions of the Calico Hills Formation and Prow Pass Tuff (Crater Flat Group)}

Recent review by Moyer and Geslin (1995) of older samples, data, and published lithologic descriptions has led to a refined subdivision of both the Calico Hills Formation and the Prow Pass Tuff, as these units were redefined by Sawyer and others (1994). The names and sequence of the informal units described by Moyer and Geslin from the Calico Hills Formation and the Prow Pass Tuff are illustrated in table 1 .

Moyer and Geslin (1995) indicate that the Calico Hills Formation in the vicinity of Yucca Mountain comprises five pyroclastic units, a dominantly reworked "bedded-tuff" unit, and a basal volcaniclastic sandstone. Some of these units appear regionally discontinuous. The pyroclastic intervals are generally ash-flow tuff deposits separated by locally preserved air-fall tuff horizons; the content and composition of pumice clasts and lithic fragments are locally diagnostic of the different ashflow groupings. The Calico Hills Formation, in notable contrast to the tuffs of the entire Paintbrush Group, contains volumetrically significant quantities of quartz phenocrysts, whereas the Paintbrush Group Tuffs are virtually quartz-free. There are indications that the basal sandstone may represent material reworked from the Wahmonie Formation, a distinctive, more mafic volcanic assemblage (Sawyer and others, 1994) not generally present in the Yucca Mountain region.

Moyer and Geslin have concluded that the Prow Pass consists of four regionally correlative pyroclastic tuff units plus an underlying interval of 
Table 2: Zonation of the Tiva Canyon and Topopah Spring Tuffs According to Buesch and Others (1996) Showing Parallel Subdivisions

[Lithophysal intervals are shaded]

\begin{tabular}{|c|c|}
\hline Tiva Canyon Tuff (Tpc) & Topopah Spring Tuff (Tpt) \\
\hline crystal-rich member (Tpcr) & crystal-rich member (Tptr) \\
\hline vitric zone (Tpcrv) & vitric zone(Tptrv) \\
\hline non- to partially welded subzone (Tpcrv3) & non- to partially welded subzone (Tptrv3) \\
\hline moderately welded subzone (Tpcrv2) & moderately welded subzone (Tptrv2) \\
\hline vitrophyre subzone (Tpcrv1) & vitrophyre subzone (Tptrv1) \\
\hline nonlithophysal zone (Tpcrn) & nonlithophysal zone (Tptrn) \\
\hline \multirow{2}{*}{\multicolumn{2}{|c|}{$\begin{array}{l}\text { subvitrophyre transition subzone (Tpcrn4) } \\
\text { pumice-poor subzone (Tpcrn3) }\end{array}$}} \\
\hline & \\
\hline \multicolumn{2}{|l|}{ mixed pumice subzone (Tpcrn2) } \\
\hline crystal transition subzone (TpernI) & crystal transition subzone (TptrnI) \\
\hline lithophysal zone & lithophysal zone \\
\hline crystal transition subzone (Tpcrl1) & crystal transition subzone (Tptri1) \\
\hline crystal-poor member & crystal-poor member \\
\hline upper lithophysal zone & upper lithophysal zone \\
\hline spherulite-rich subzone (Tpcpul1) & cavernous lithophysae subzone (Tptpul2) \\
\hline & small lithophysae subzone (Tptpul1) \\
\hline middle nonlithophysal zone (Tpcpmn) & middle nonlithophysal zone (Tptpmn) \\
\hline upper subzone (Tpcpmn3) & upper subzone (Tptpmn3) \\
\hline lithophysae-bearing subzone (Tpcpmn2) & lithophysae-bearing subzone (Tptpmn2) \\
\hline lower subzone (Tpcpmn1) & lower subzone (TptpmnI) \\
\hline lower lithophysal zone (Tpcpll) & lower lithophysal zone (Tptpli) \\
\hline lower nonlithophysal zone (Tpcpln) & lower nonlithophysal zone (Tptpln) \\
\hline hackly subzone (Tpeplnh) & \\
\hline columnar subzone (Tpcplnc) & \\
\hline spherulitic pumice interval & \\
\hline (Tpcplnc3) & \\
\hline argillic pumice interval (Tpcplnc2) & \\
\hline vitric pumice interval (Tpcplnc1) & \\
\hline vitric zone (Tpcpv) & vitric zone (Tptpv) \\
\hline vitrophyre subzone (Tpcpv3) & vitrophyre subzone (Tptpv3) \\
\hline moderately welded subzone (Tpcpv2) & moderately welded subzone (Tptpv2) \\
\hline non-to partially welded subzone (Tpepv1) & non-to partially welded subzone (Tptpv1) \\
\hline Pre-Tiva Canyon Tuff bedded tuff (Ppbt2) & Pre-Topopah Spring Tuff bedded tuff (Tpbt1) \\
\hline
\end{tabular}

"bedded tuff." Separation of the different ash flows is based in part on differences in welding and in the proportions and types of phenocrysts, pumices, and lithic fragments. The Prow Pass Tuff is crystal rich in comparison with the volumetrically dominant crystal-poor lower members of the Topopah Spring and Tiva Canyon Tuffs. Also in contrast with the Paintbrush units, the Crater Flat Group tuffs are quartz-bearing.

\section{The USW SD-9 Drill Hole}

\section{Location}

Drill hole USW SD-9 is located at Nevada state plane coordinates ${ }^{\ddagger} 561,818.0$ East, $767,988.5$ North [fig 1(b)]. The collar of the hole is at an elevation of $4275 \mathrm{ft}(1303.35 \mathrm{~m})$. The hole is located approximately half-way up Wren Wash on the eastern side of Yucca Mountain. The hole is approximately $500 \mathrm{ft}(150 \mathrm{~m})$ west of the surface trace of 
the Ghost Dance Fault as mapped by Scott and Bonk (1984). The hole is also some $250 \mathrm{ft}(75 \mathrm{~m})$ to the west of the ESF main test level drift, as that drift was shown on design documents current when the hole was sited (fig. 3).

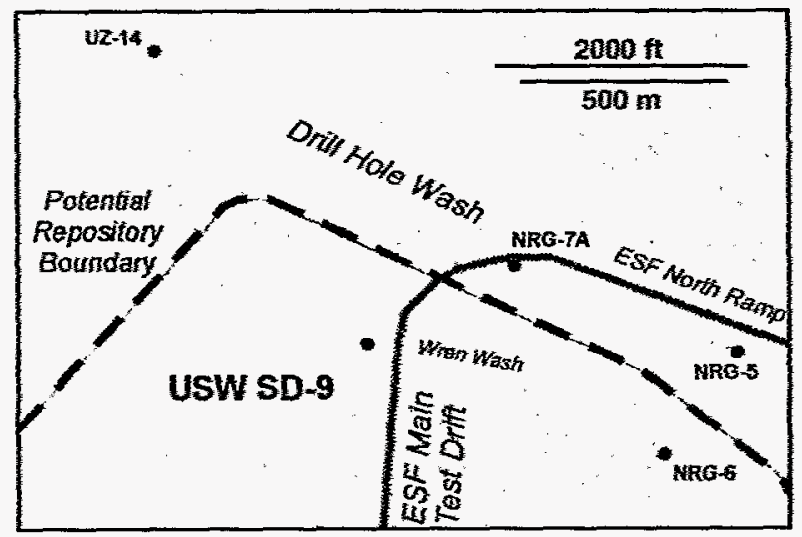

Figure 3. Location map of the potential repository region showing the USW SD-9 drill hole in Wren Wash and in relationship to nearby drill holes and the Exploratory Studies Facility.

\section{Drilling History}

Drill hole SD-9 was started on May 6, 1994, when the top of the borehole was augered to a depth of $8.65 \mathrm{ft}(2.64 \mathrm{~m})$ to set surface-conductor pipe. Bedrock was encountered at $52.6 \mathrm{ft}(16.04 \mathrm{~m})$ on May 25 beneath drill-pad fill and colluvial overburden. Continuous coring operations commenced using $\mathrm{PQ}$-sized tools (yielding 3.35-inch core), and the hole reached a depth of $1000-\mathrm{ft}(328 \mathrm{~m})$ during the last core run on June 16. Moist core was noted below a depth of $1308 \mathrm{ft}(398.78 \mathrm{~m})$ on June 27 , starting just above the basal vitrophyre of the Topopah Spring Tuff (unit Tptpv3, table 1). Perched water began flowing into the borehole at a slow rate at a depth of $1353 \mathrm{ft}(412.50 \mathrm{~m})$. The borehole was deepened to $1489.2 \mathrm{ft}(454.02 \mathrm{~m})$ and

\footnotetext{
Note: Nevada State Plane coordinates in feet are widely used on the Yucca Mountain Project. These coordinates are for the central zone of Nevada and are based on a Transverse Mercator projection. The origin of this projection for the central zone of Nevada is latitude $34^{\circ} 45^{\prime} \mathrm{N}$, and the central meridian is at longitude $116^{\circ} 40^{\circ} \mathrm{W}$. Metric conversions of Nevada State Plane Coordinates are distinctly separate from true metric coordinates obtained using the 10,000 metre Universal Transverse Mercator grid, Zone II.
}

borehole conditions were observed using a downhole video camera. Water samples were collected by several bailer runs for geochemical analysis. Geophysical logs were run from a depth of $1487 \mathrm{ft}$ $(453.35 \mathrm{~m})$ to the ground surface using gamma-ray, dual-induction, compensated-density, compensated epithermal-neutron, dielectric-propagation, and oriented-caliper tools.

The SD-9 drill hole was reamed to a diameter of 8-1/2 inches to a depth of $1487.6 \mathrm{ft}(453.54 \mathrm{~m})$ between July 26 to August 16, and 7-inch casing was placed in the borehole to prevent further inflows of perched water. Coring resumed on August 29, and the regional water table was encountered at $1877 \mathrm{ft}(572.26 \mathrm{~m})$ on September 10. A string of 4.5-inch casing was set to a depth of $1907 \mathrm{ft}(581.40 \mathrm{~m})$ to protect the unsaturated zone from contamination, and coring resumed using $\mathrm{HX}$ equipment (2.4-inch core). The hole was reached total depth at $2223.1 \mathrm{ft}(677.77 \mathrm{~m})$ on September 26,1994 . As of January 1996, no geophysical logs had been obtained from this lower portion of the SD-9 drill hole.

\section{Method of Study}

\section{Geologic Logging and Core Description}

Geologic logging and description of drill core is principally an interpretive activity. As such, the resulting geologic $\log$ is dependent upon the skill and experience of the individual performing the examination. The logging procedure used to describe core from drill hole USW SD-9 and other holes of the Systematic Drilling Program emphasizes physical description in an attempt to eliminate partially dependence on stratigraphic nomenclature that may change over time (compare Scott and Bonk, 1984; Buesch and others, 1996). A standardized geologic log form is used to record observations of lithology, composition, alteration, structure, and similar features, and of changes in those multiple characteristics with depth. The observations are thus effectively independent of the names applied to units of similar or contrasting character.

Interpretative geologic logging and core description consists of observing the rock in its intact, relatively undisturbed state. Core was laid 
out in continuous profile on examination tables at the Yucca Mountain Project Sample Management Facility. A graphical geologic log was prepared at a scale of $1: 120$ (one inch equals 10 feet) after macroscopic visual examination using a hand lens, binocular microscope, videotaped images and photographs of core intervals previously removed for laboratory measurement of selected material properties. The geologic log includes description of:

- contacts between geologic units

- degree of welding

- degree of devitrification

- size, type, and abundance of pumice

- size, type, and abundance of lithic clasts

- size, type, and abundance of phenocrysts

- size, type, and abundance of lithophysal cavities

- type, nature, and degree of alteration

- presence or absence of bedding or other depositional features

- fault zones or shear zones

- joints or fractures and fracture frequency

- percent core recovery

- RQD (rock quality designation)

Rock color descriptions follow the naming conventions prescribed in the rock-color chart published by the Geological Society of America (1991).

\section{Laboratory Material Properties}

A limited suite of framework material properties were measured in the laboratory for core samples taken from the USW SD-9 drill hole. Adjoining core samples were preserved at the drilling rig in sealed steel cans and plastic Lexan ${ }^{\mathrm{TM}}$ tubing. In-situ water contents were determined by gravimetry from the canned samples. Porosity, bulk density and particle density also were determined by gravimetry for the canned samples using Archimedes' principle. Initial water content and porosity were used to determine approximate insitu saturations. Machined core plugs were cut from the larger samples preserved in Lexan ${ }^{\mathrm{TM}}$ and used to determine saturated hydraulic conductivity using Darcy's law relating water flow and pressure drop; the corresponding porosity values for these plugs were also determined. The laboratory property determinations were a collaborative effort of
Sandia National Laboratories and the U.S. Geological Survey, Hydrologic Research Facility (USGS, 1991a).

\section{Geology of Drill Hole USW SD-9}

\section{Overview}

Drill hole USW SD-9 is located on a small divide between two washes draining the eastern slope of Yucca Mountain (fig. 3); this topographic position places the hole low within the Tiva Canyon stratigraphic section. Only the lowermost 38.7 $\mathrm{ft}$ of the Tiva Canyon Tuff, consisting of the lower nonlithophysal and the lower vitric zones, was encountered in the drill hole. A summary of geologic unit contacts is presented in table 3. Detailed lithologic descriptions for the rocks encountered in drill hole USW SD-9 are presented in Appendix A, and the corresponding, detailed geologic log sheets are in Appendix B.

The core begins in the Tiva Canyon Tuff with light-tan-gray, two-foot interval containing dark, vitric, pumice clasts and representing the lower part of the columnar subzone of the lower nonlithophysal zone. This unit is bounded below by a 1-1/ 2-inch-wide, low-angle fault filled with sandy clay gouge. Below this fault is $9.3 \mathrm{ft}(2.84 \mathrm{~m})$ of mostly nonwelded material belonging to the two lower vitric zones of the Tiva Canyon. Approximately ten $\mathrm{ft}$ ( $3 \mathrm{~m}$ ) of section appears to have been cut out by the fault, but the actual amount of movement along the fault is unknown. The lower vitrophyre of the Tiva Canyon Tuff (Tpcpv3) is not present, and the gradationally less welded sequence beneath the fault represents what has also been termed the "shardy base" of the Tiva Canyon Tuff (Istok and others, 1994). A sequence of essentially nonwelded units underlies the Tiva Canyon Tuff section. Named units include the Yucca Mountain Tuff and Pah Canyon Tuff, each of which is separated from its neighbors by "bedded tuff" units of mixed lithology.

The Topopah Spring Tuff section, which underlies the nonwelded units, has a total thickness of $1211.5 \mathrm{ft}(369.25 \mathrm{~m})$. The top of the upper nonwelded zone (Tptrv3) has been located at $252.6 \mathrm{ft}$ $(77.01 \mathrm{~m})$. Welding increases markedly at the upper contact of the "caprock" vitrophyre (Tptry). 
Table 3: Stratigraphic Unit Upper Contacts and Unit Thicknesses for the USW SD-9 Drill Hole

[All values in feet. Geologic names from nomenclature of Buesch and others (1996). Stratigraphic compendium, version of September 1995. Leaders (--): no difference in depth to contact; $n / a$ : contact not included in stratigraphic compendium]

\begin{tabular}{|c|c|c|c|c|}
\hline Unit & Abbreviation & $\begin{array}{l}\text { Depth to } \\
\text { Upper } \\
\text { contact }\end{array}$ & $\begin{array}{c}\text { Apparent } \\
\text { thickness } \\
\text { (ft) }\end{array}$ & $\begin{array}{l}\text { Depth from } \\
\text { Stratigraphic } \\
\text { Compendium }\end{array}$ \\
\hline \multicolumn{5}{|l|}{ Tiva Canyon Tuff (Tpc) $-38.7 \mathrm{ft}$ thick ${ }^{1}$} \\
\hline Crystal-poor lower nonlithophysal zone & Tpcplnc & $53.6^{1}$ & $2.1^{2}$ & 30.0 \\
\hline Crystal-poor vitric zone & Tpcpv & 55.7 & 36.6 & 57.2 \\
\hline moderately welded subzone & Tpcpv2 & 55.7 & $9.3^{2}$ & 57.2 \\
\hline nonwelded subzone & Tpcpv1 & 65.0 & 27.3 & $61.0^{3}$ \\
\hline Pre-Tiva Canyon bedded tuff & Tpcbt4 & 92.3 & 3.6 & 92.4 \\
\hline Yucca Mountain Tuff (Tpy) $-45.0 \mathrm{ft}$ thick & Tpy & 95.9 & 45.0 & -- \\
\hline Slightly welded zone & - & $121.7-133.7$ & 12.0 & $\mathrm{n} / \mathrm{a}$ \\
\hline Pre-Yucca Mountain bedded tuff & Tpbt3 & 140.9 & $16.8^{2}$ & 140.8 \\
\hline Pah Canyon Tuff (Tpp) $-69.4 \mathrm{ft}$ thick & Tpp & 157.7 & 69.4 & 156.5 \\
\hline Pre-Pah Canyon bedded tuff & Tpbt2 & 227.1 & 25.5 & \multirow[t]{2}{*}{226.6} \\
\hline Topopah Spring Tuff (Tpt) $-1211.50 \mathrm{ft}$ thick & Tpt & & & \\
\hline Crystal-rich vitric zone & Tptrv & 252.6 & 19.5 & 255.6 \\
\hline nonwelded subzone & Tptrv3 & 252.6 & 15.4 & 255.6 \\
\hline moderately welded subzone & Tptrv2 & 266.1 & 2.5 & 266.7 \\
\hline "caprock vitrophyre" subzone & Tptrv1 & 268.6 & 4.1 & $268.5^{3}$ \\
\hline Crystal-rich nonlithophysal zone & Tptrn & 272.1 & 167.1 & 272.2 \\
\hline Crystal-rich lithophysal zone & Tptrl & 439.2 & & -- \\
\hline Crystal transition interval & -- & $448.2-485.2$ & 37.0 & $\mathrm{n} / \mathrm{a}$ \\
\hline Compositional transition & -- & $454.7-468.6$ & 13.9 & $\mathrm{n} / \mathrm{a}$ \\
\hline Crystal-poor upper lithophysal zone & Tptpul & 485.2 & 289.6 & $484.2^{3}$ \\
\hline Crystal-poor middle nonlithophysal zone & Tptpmn & 728.8 & 117.0 & 736.8 \\
\hline lithophysae-bearing subzone & Tptpmn2 & $788.1-812.5$ & 24.4 & $\mathrm{n} / \mathrm{a}$ \\
\hline Crystal-poor lower lithophysal zone & Tptpll & 845.8 & 341.2 & -- \\
\hline Crystal-poor lower nonlithophysal zone & Tptpln & 1187.0 & 178.0 & $1185.8^{3}$ \\
\hline Crystal-poor vitric zone & Tptpv & 1365.0 & 99.1 & -- \\
\hline lower vitrophyre subzone & Tptpv3 & 1365.0 & 53.7 & -- \\
\hline moderately welded subzone & Tptpv2 & 1418.7 & 26.3 & $1418.4^{3}$ \\
\hline nonwelded subzone & Tptpv1 & 1445.0 & 19.0 & 1425.7 \\
\hline Pre-Topopah Spring bedded tuff & Tpbtl & 1464.1 & 15.8 & 1464.1 \\
\hline Calico Hills Formation (Tac) $-340.8 \mathrm{ft}$ thick & & & & \\
\hline unit 3 & Tac3 & 1479.9 & 106.2 & 1479.9 \\
\hline unit 2 & Tac2 & 1586.1 & 151.4 & $\mathrm{n} / \mathrm{a}$ \\
\hline unit 1 & Tac1 & 1737.5 & 26.9 & $\mathrm{n} / \mathrm{a}$ \\
\hline bedded tuff & Tacbt & 1764.4 & 39.0 & 1764.4 \\
\hline tuffaceous sandstone & Tacbs & 1803.4 & 17.3 & $\mathrm{n} / \mathrm{a}$ \\
\hline Prow Pass tuff (Tcp) $-402.4 \mathrm{ft}$ thick $^{1}$ & & & & \\
\hline unit 4 & Tcp4 & 1820.7 & 48.0 & 1820.7 \\
\hline unit 3 & Tcp3 & 1868.7 & $147.1^{2}$ & $\mathrm{n} / \mathrm{a}$ \\
\hline unit 2 & Tcp2 & 2015.8 & 79.5 & $\mathrm{n} / \mathrm{a}$ \\
\hline unit 1 & Tep1 & $2095.3^{1}$ & $127.8^{l}$ & $\mathrm{n} / \mathrm{a}$ \\
\hline
\end{tabular}

' entire unit not penetrated; partial thickness only

2 may not be true thickness because of faulting

${ }^{3}$ markedly gradational contact subject to interpretation 
Devitrification begins at $272.1 \mathrm{ft}(82.96 \mathrm{~m})$, defining the contact of the vitrophyre with the underlying upper nonlithophysal zone. The upper portion of the section is weakly, but progressively more lithophysal down to the upper contact of the upper lithophysal zone at $439.2 \mathrm{ft}(133.90 \mathrm{~m}){ }^{\dagger}$ A compositional-transition interval has been described approximately $200 \mathrm{ft}(60 \mathrm{~m})$ below the top of the unit where the Topopah Spring changes gradationally from quartz latite to rhyolite. This compositional-transitional interval is $13.9 \mathrm{ft}(4.24 \mathrm{~m})$ thick and was observed between 454.7 and $468.6 \mathrm{ft}$ (138.59-142.82 m). A somewhat overlapping transition interval, involving principally the abundance of phenocrysts, as been identified as a "crystaltransition" interval from about 448.2 to $485.2 \mathrm{ft}$ (136.60-147.88 m). The base of this crystal-transition interval essentially corresponds to the contact between the lower crystal-poor member and the overlying crystal-rich members of the Topopah Spring Tuff described by Buesch and others (1996). There is, however, no apparent physical or depositional break associated with this "contact."

Very large lithophysae within the upper lithophysal zone are represented in the core as broken zones or unrecovered intervals, and these large lithophysal cavities are visible in the downhole video logs beginning at a depth of $441.5 \mathrm{ft}(134.60$ $m)$. Although the number of smaller lithophysae diminishes beginning at $655.0 \mathrm{ft}(199.70 \mathrm{~m})$, isolated large lithophysal cavities are visible in videocamera logs down to about $760 \mathrm{ft}(231.71 \mathrm{~m})$, which is well into the middle nonlithophysal zone. The middle nonlithophysal zone is defined between depths of 728.8 and $845.8 \mathrm{ft}$ (222.20 $257.87 \mathrm{~m}$ ). A "lithophysal-bearing subzone" is identified within the middle nonlithophysal zone from 788.1 to $812.5 \mathrm{ft}(240.27$ to $247.71 \mathrm{~m})$. In contrast to the upper part of the middle nonlithophysal zone, the lower $33 \mathrm{ft}(10.06 \mathrm{~m})$ of this unit

\footnotetext{
${ }^{\dagger}$ Note: The issue of distinguishing lithophysal and nonlithophysal zones is complex and represents a long-standing issue of some contention within the Yucca Mountain Project ever since Ortiz and others (1985) used the abundance of lithophysae as a criterion for distinguishing subunits of the Topopah Spring Tuff; see see "Thermal/Mechanical Units" beginning on page 11. A brief discussion of the criteria used to separate informally named lithophysal zones from other lithophysaebearing units is presented beginning on page 12 .
}

is relatively intàct and exhibits a dense, compact, highly silicified (altered) texture.

The lower lithophysal zone was encountered at a depth of $845.8 \mathrm{ft}(257.87 \mathrm{~m})$, and large-diameter lithophysal cavities, intense fracturing, and numerous unrecovered zones were encountered beginning at about $860 \mathrm{ft}(262.20 \mathrm{~m})$. The large lithophysae continue well below the lower limit of the lower lithophysal zone at $1187.0 \mathrm{ft}(361.78 \mathrm{~m})$, extending almost to the depth of the lower vitrophyre. Intervals containing large, angular, rhyolite lithic fragments with clasts to $60.0 \mathrm{~mm}$ diameter are found at a number of depths from $1031.0 \mathrm{ft}$ $(314.33 \mathrm{~m})$ to $1267.8 \mathrm{ft}(386.52 \mathrm{~m})$. A lithic zone containing 4-5 percent fragments of mixed quartz latite and rhyolite composition is present from $1267.8 \mathrm{ft}$ to $1442.2 \mathrm{ft}(439.70 \mathrm{~m})$.

The top of the lower vitrophyre occurs at a depth of $1418.7 \mathrm{ft}(432.53 \mathrm{~m})$ and the unit is $53.7 \mathrm{ft}$ $(16.37 \mathrm{~m})$ thick. Below the lower vitrophyre, the moderately-to-partially welded vitric zone contains a lithic-rich interval from 1431.5 to $1442.2 \mathrm{ft}$ ( 436.43 to $439.70 \mathrm{~m}$ ) Zeolitized pumice and very weakly altered shard boundaries indicate incipient zeolitization beginning at a depth of $1442.2 \mathrm{ft}$ (439.70 m). A 3.8-ft (1.16 m) thick, pink, zeolitized interval from 1432.8 to $1436.6 \mathrm{ft}$ (436.83 to $437.99 \mathrm{~m}$ ), within the lithic-rich interval, may represent a large zeolitic block derived from deeper stratigraphic units. The basal nonwelded zone extends from 1445.0 to $1464.1 \mathrm{ft}$ ( 440.55 to 446.37 $\mathrm{m})$. The Topopah Spring Tuff is underlain by 15.8 $\mathrm{ft}(4.82 \mathrm{~m})$ of bedded tuff.

The Calico Hills Formation was encountered at a depth of $1479.9 \mathrm{ft}(451.05 \mathrm{~m})$ and the unit is $340.8 \mathrm{ft}(103.87 \mathrm{~m})$ thick. The Calico Hills in this drill hole has been subdivided into three ash-flow tuff units, a reworked bedded tuff unit, and a basal tuffaceous sandstone, following the usage of Moyer and Geslin (1995). The unit is essentially entirely zeolitic. Numerous intervals of prominent red-brown rhyolitic lithic fragments are typical within the ash-flow deposits of Calico Hills.

The Calico Hills Formation is underlain by the Prow Pass Tuff, beginning at a depth of $1820.7 \mathrm{ft}$ $(554.92 \mathrm{~m})$. This unit is subdivided into four ashflow tuff units (Moyer and Geslin, 1995) that are a 
minimum of $402.4 \mathrm{ft}(122.65 \mathrm{~m})$ thick in SD-9. This observed thickness is not adjusted for the unknown effects of a minor fault observed in ashflow unit 3. Drill hole USW SD-9 did not reach the base of ash-flow unit 1.

\section{Thermal/Mechanical Units}

A somewhat formalized thermal, mechanical, and hydrologic stratigraphy was defined originally by Ortiz and others (1985), based upon preliminary concepts put forward by Lappin and others (1982). The concept was to define coherent rock units for design and performance analyses based on rock properties, rather than on more classical geologic criteria. According to the original citation, "Two properties used to differentiate units are porosity and grain density" (p. 8). Further reading of the Ortiz reference indicates that this subdivision based on porosity and grain density translates to a first order subdivision between welded and nonwelded materials, with additional subdivisions determined by whether the rocks are still vitric, or whether they have been altered either to a devitrification mineral assemblage or to zeolites. The socalled thermal/mechanical units were correlated in table 1 of Ortiz and others with the more conventional geologic stratigraphy then in use; this correlation is essentially reproduced intact in table 1 of this report. The thermal/mechanical units, as originally described, also subdivided the Topopah Spring welded interval into a lithophysae-rich upper portion in contrast with the lower part, which was presumed to be relatively poor in lithophysae (p. 11). In fact, the distribution of lithophysal alteration and lithophysal cavities is more complex than was recognized by Ortiz and her coworkers.

It is important to note that the major changes in material properties recognized as the basis for subdividing the volcanic section at Yucca Mountain by Ortiz and others do not correspond to the boundary of the geologic units, which are identified principally by major breaks and changes in the genetic process that produced the rocks of the southwestern Nevada volcanic field. The descriptive but unfortunate use by Ortiz and her coworkers of the conventional geologic names as the "base" for the thermal/mechanical unit names can cause confusion if the critical distinction between propertybased and process-based nomenclature is not fully understood. Nevertheless, this physical-property subdivision that aggregates materials that behave in a similar manner has proven to be an enduring feature of the Yucca Mountain Project.

Table 4 presents the thermal/mechanical units identified from the SD-9 drill core. In keeping with Ortiz and others (1985), who presented a series of surfaces representing the bottom of each thermal/ mechanical unit, table 4 gives the depths to each basal contact as well as the apparent thickness of each unit.

Table 4: Basal Contacts and Thicknesses of Thermal/Mechanical Units [Definitions of thermal/mechanical units from Ortiz and others (1985), p. 11-12]

\begin{tabular}{clcc}
\hline \multicolumn{1}{c}{ Unit } & $\begin{array}{c}\text { Lower } \\
\text { Contact } \\
\text { (ft) }\end{array}$ & $\begin{array}{c}\text { Apparent } \\
\text { Thickness } \\
\text { (ft) }\end{array}$ \\
\hline TCw: & Tiva Canyon welded & 55.7 & -- \\
PTn: & Paintbrush nonwelded & 268.0 & 212.3 \\
TSw1: & Topopah Spring welded, "lithophysae rich" & 728.8 & 460.8 \\
TSw2: & Topopah Spring welded, "lithophysae poor" & 1365.0 & 636.2 \\
TSw3: & Topopah Spring welded, vitrophyre & 1418.7 & 53.7 \\
CHn1: & Calico Hills nonwelded—lower nonwelded part of & 1764.4 & 345.7 \\
& Topopah Spring Tuff plus ash-flow tuffs of Calico & & \\
& Hills Formation & & \\
CHn2: & Calico Hills nonwelded—basal reworked zone and & 1820.7 & 56.3 \\
& "bedded tuffs" of Calico Hills Formation & & \\
CHn3: & "Calico Hills" nonwelded-upper nonwelded ash- & $1910^{1}$ & 89.3 \\
& flow tuffs of the Prow Pass Tuff & & \\
\hline
\end{tabular}


Table 4: Basal Contacts and Thicknesses of Thermal/Mechanical Units (Continued) [Definitions of thermal/mechanical units from Ortiz and others (1985), p. 11-12]

\begin{tabular}{clcc}
\hline \multicolumn{1}{c}{ Unit } & $\begin{array}{c}\text { Lower } \\
\text { Contact } \\
\text { (ft) }\end{array}$ & $\begin{array}{c}\text { Apparent } \\
\text { Thickness } \\
\text { (ft) }\end{array}$ \\
\hline PPw: & $\begin{array}{l}\text { Prow Pass welded-welded ash-flow tuffs of the } \\
\text { Prow Pass Tuff }\end{array}$ & 2012.4 & 102.4 \\
CFUn $\quad \begin{array}{l}\text { Upper Crater Flat nonwelded-lower nonwelded } \\
\text { ash-flow tuffs of the Prow Pass Tuff }\end{array}$ & $(2223.1)^{2}$ & -- \\
\hline & & \\
${ }^{1}$ Gradational contact; exaction location somewhat uncertain & \\
\end{tabular}

\section{Structural Geology of SD-9}

Three faults were observed in the SD-9 core. The uppermost of these faults is found at a depth of $55.7 \mathrm{ft}(16.98 \mathrm{~m})$, and it separates the columnar subzone of the Tiva Canyon Tuff, lower nonlithophysal zone, from the shardy-base subzone. This structure is a very low-angle fault (essentially normal to the core axis) containing approximately a 1to 1.5 -inch thick (3.9-5.9 mm) mixture of sandy and clayey gouge. The base of the columnar section is intensely fractured and these fractures are filled with cemented, milled fragments of the underlying shardy-base vitric interval. Stratigraphic offset is estimated to be no more than about $10 \mathrm{ft}(3 \mathrm{~m})$; however, to achieve this amount of stratigraphic offset on a displacement surface nearly parallel to depositional layering logically requires a significant amount of structural movement.

A second fault occurs within the slightly welded zone of the Yucca Mountain Tuff at a depth of $122.1 \mathrm{ft}(37.23 \mathrm{~m})$. About two inches $(0.05 \mathrm{~m})$ of soft clay gouge was found in this low-angle fault, although no indication of relative movement was apparent. No estimate of the offset along this fault is possible. Using analogy with the fault identified higher in the borehole at $55.7 \mathrm{ft}$, the similar-toslightly thicker interval of recovered fault gouge suggests that stratigraphic offset may be roughly comparable (approximately $10 \mathrm{ft}, 3 \mathrm{~m}$ ), even though no offset marker horizons or thinned stratigraphic zones are present to provide direct evidence of offset. Achieving $10 \mathrm{ft}$ of stratigraphic offset along a flat-lying fault suggests much larger structural displacement, however.
A third fault was identified within the Prow Pass Tuff at a depth of $1991.0 \mathrm{ft}(607.01 \mathrm{~m})$. This is also a low-angle fault (bounding surfaces at approximately $70-75^{\circ}$ to the core axis), which is represented by about $2-1 / 2$ inches $(6-7 \mathrm{~cm})$ of plastic, clay-rich gouge. This fault is estimated to exhibit approximately $62.7 \mathrm{ft}(19.12 \mathrm{~m})$ of stratigraphic displacement. The amount of structural movement on this relatively low-angle fault unquestionably is much greater.

\section{Lithophysal Zones}

The definition of lithophysal zones within the welded tuffs at Yucca Mountain is a complex problem that has a long history on the Yucca Mountain Project. The issue involves distinguishing (informally) named "lithophysal zones" from other intervals that may contain lithophysae. In logging and describing other recent core obtained from Yucca Mountain, T. C. Moyer (Science Applications International Corporation/U.S. Geological Survey, personal communication, 1994) originally indicated that lithophysal zones were to be defined simply based on "the presence of lithophysae." Ortiz and others $(1985$, p. 11) cited a threshold value of "approximately $10 \%$ by volume lithophysal cavities" as the criterion for separating their "lithophysae-rich" (TSw1) and "lithophysae-poor" (TSw2) subunits of the Topopah Spring welded tuff. Buesch and others (1996) present a more specific description of criteria for the identification of specifically named lithophysal zones (page 18; quoted almost in its entirety):

Lithophysal zones occur where vapor concentrates in the densely welded parts of ignimbrites [ash-flow tuffs] to form lithophysal cavities (Ross and Smith, 1961).... Lithophysae consist of a cavity, which is commonly coated with vapor-phase miner- 
als on the inner wall of the cavity, a fine-grained rim surrounding the cavity wall, and a thin very fine-grained border... Many lithophysae in the Tiva Canyon and Topopah Spring Tuffs have light-gray (N8) to grayish-orange pink (IOR8/2) rims of microscopic to barely macroscopic elongate cry'stals that radiate from the walls of the lithophysae into the surrounding groundmass. These rims are up to 3-cm wide. Locally, rims have $1-$ to $3-\mathrm{mm}$ wide, grayish red-purple (5YR4/2) borders. Associated with the lithophysae are light-gray' (N8) to grayish-orange pink (10R8/2) spots $1-$ to $5-\mathrm{cm}$ in diameter. Some spots may represent the cross sections of rims on lithophysae, whereas others have a crystal or lithic clast in the core that could have acted as a nucleation site. There is no genetic interpretation for the spots; however, they are characteristic for some lithophysal zones. Lithophysal zones in the Tiva Canyon and Topopah Spring Tuffs are identified by a combined occurrence of lithophysae and spots [emphasis added]. The shape of the lithophysae and spots and width of the rims on the lithophysae can also be diagnostic of specific zones. Locally surface exposures contain lithophysae with diameters of up to I $\mathrm{m}$; thus regions of poor core recovery might indicate large lithophysae [emphasis added].

Vapor-phase altered rocks containing abundant (greater than 10 percent) lithophysae, with or without significant open-space cavities, are readily recognized and are easily assigned to discrete lithophysal zones. The real complication appears to be the recognition and treatment of lithophysal-style alteration associated with cavities that are too large to be recognized directly in the core (and by extension, recognition of the mere presence of lithophysae). Where very large lithophysae are penetrated by the drill string, the thin, brittle septae of rock dividing the cavities typically are shattered by the force of the rotating drill bit; this logically results in intervals of rubble and unrecovered core (cavity plus rubble blown away from the bit face into other parts of the cavity). Diagnostic, remnant vaporphase alteration rims and distinctive cavity-coating minerals frequently can be identified in the recovered rubble fragments. The question essentially reduces to whether or not an interval exhibiting these very large lithophysal cavities, but without significant quantities of the small-scale lithophysae or vapor-phase-altered spots, can be classified as a "lithophysal zone."
Descriptions of the SD-9 drill core for this report use multiple criteria derived from the description of lithophysal zones presented by Buesch and others (quotation above). In keeping with the logging philosophy presented in the section on core description beginning on page 7 , the principal emphasis of the Systematic Drilling Program has been placed on objective description of the core and associated down-hole video imagery (particularly that presented in the foot-by-foot lithologic $\log$ contained in Appendix B). Association of unit names with these descriptions is distinctly secondary. Generally, named "lithophysal zones" identified in this report contain rocks exhibiting small (mesoscale) lithophysae and/or "spots," and whose matrix is grayish red-purple in color. This type of material typically is associated with vapor-phase alteration of varying, but relatively strong, intensity immediately adjacent to observable lithophysae. The matrix of rocks from named nonlithophysal zones is typically more brownish or orangish in color; note that description of rock colors is somewhat subjective, even when using standard rock-color charts. The finer-scale texture of the rock between lithophysal cavities in lithophysal zones is typically stretched and foliated, as if distorted by the inflating lithophysal cavities. Fracturing within named lithophysal zones is generally distinctive as well; fractures tend to be shorter and more irregular in form, and to exhibit rougher surfaces than those encountered outside the named lithophysal zones. Unquestionably, some of the names assigned in this report are somewhat in conflict with the description of the corresponding interval. The descriptions should take precedence, as these do reflect local heterogeneities in the tuff mass.

Drill hole USW SD-9 was collared below the lithophysal intervals of the Tiva Canyon Tuff. Within the Topopah Spring Tuff, prominent lithophysal alteration associated with the crystal-rich and crystal-poor upper lithophysal zones begins at $436 \mathrm{ft}(132.93 \mathrm{~m})$, approximately $164 \mathrm{ft}(50 \mathrm{~m})$ below the caprock vitrophyre (see log sheet 7 , Appendix B). Lithophysae increase rapidly in both abundance and size by a depth of $441.5 \mathrm{ft}$ (134.60 $\mathrm{m}$ ), as does the incidence of intervals of broken and unrecovered core. Many intervals of "lost" core are attributed to void space representing large litho- 
physae that are several core-diameters across. The highly broken nature of much "core" recovered from lithophysal zones is attributed to disintegration of the vuggy tuff during drilling.

Lithophysal cavity development decreases significantly beginning at a depth of approximately $630 \mathrm{ft}$ (192.07 m; log sheets 9-10, Appendix B); the middle nonlithophysal zone is distinguished beginning at $728.8 \mathrm{ft}(222.20 \mathrm{~m}$; log sheet 11$)$. Although lithophysae were not observed in the core, broken and unrecovered zones continue to occur through the middle nonlithophysal zone confirming the presence of large diameter lithophysae that are visible in the down-hole video. A 24-foot (8-m)-thick "lithophysae-bearing subzone" of the middle nonlithophysal zone (table 2), identified from 788.1 to $812.5 \mathrm{ft}(240.27$ to $247.71 \mathrm{~m})$ depth (log sheet 13), also represents an interval of prominent large lithophysal cavity development. Only the lower 33.3-ft (10.15-m)-thick portion of the middle nonlithophysal zone appears to be devoid of large lithophysae (log sheet 12 ).

The lower lithophysal zone of the Topopah Spring Tuff was encountered at a depth of $845.8 \mathrm{ft}$ ( $257.87 \mathrm{~m}$; $\log$ sheet 13$)$. In addition to lithophysae visible in the core, the material recovered from this unit also includes broken and unrecovered zones that appear to correspond to large (many centimeter) lithophysal cavities in visible in downhole video logs. No lithophysae are visible in the recovered core material from 899 to $962.6 \mathrm{ft}$ ( 274.09 to $293.48 \mathrm{~m}$; log sheets 13-14), although fragments of altered lithophysal rims, broken zones, unrecovered intervals and large lithophysae visible in the borehole video attest to their presence. Smaller lithophysae reappear in the core from 962.6 to 980 $\mathrm{ft}$ (293.48 to $298.78 \mathrm{~m}$; log sheets 14-15), although the frequency of these features appears to decrease below about $980 \mathrm{ft}$. Small, well-formed lithophysae reappear in the core at a depth of $1060 \mathrm{ft}$ $(323.17 \mathrm{~m})$; broken core and unrecovered intervals are more common below $1060 \mathrm{ft}$ as well (log sheet 16). Both recovered lithophysae and these two indirect indicators of large lithophysal cavities increase in intensity to a depth of about $1110 \mathrm{ft}$ $(338.41 \mathrm{~m})$. Below the depth of $1110 \mathrm{ft}$, the intensity of lithophysal-style alteration progressively decreases to a contact with the lower nonlitho- physal (or "mottled" zone of Scott and Bonk, 1984), drawn somewhat arbitrarily at $1187 \mathrm{ft}$ (361.89 m; log sheet 17). Indicators of large lithophysae are present, albeit less frequently, throughout of the lower Topopah Spring section (log sheets $18-20)$ to a depth of approximately $1354 \mathrm{ft}(412.80$ $\mathrm{m}$ ); the top of the basal vitrophyre occurs at a depth of $1365 \mathrm{ft}(416.16 \mathrm{~m})$.

\section{Rock Quality Considerations}

\section{Core Recovery}

Percent core recovery was determined at the drill rig by Yucca Mountain Project drilling support staff during the coring of hole USW SD-9. Recording core recovery information is a relatively mechanical process and follows a set procedure. Core recovery data are presented in Appendix C, Table C-1; this information is also presented graphically in summary form in figure 4 . Core recovery information is presented in more detail on the geologic log sheets of Appendix B, which allows inference of possible lithologic controls of lost core and as means of qualifying the reliability of the associated lithologic descriptions. Note the association of lower core-recovery values with the graphically portrayed abundance and size of lithophysal cavities on the log sheets; see also figure 4 . Description of intervals with exceptionally poor core recovery requires a subjective "reading" of multiple lines of indirect evidence.

A generalized summary of the procedure used to determine core recovery is as follows.

1) The core is laid out in an appropriate manner. Broken segments are fitted back together as well as possible to represent in-situ dimensions. Rubble is reaggregated to continuous piles of approximately the core diameter.

2) The start and stop depths of the core run are identified from information provided by the driller and the length of the core run is determined.

3) The total length of core recovered from a given run is measured using a steel tape measure and the footage is recorded.

4) Recovery is computed as the percentage of material actually recovered from that interval. 


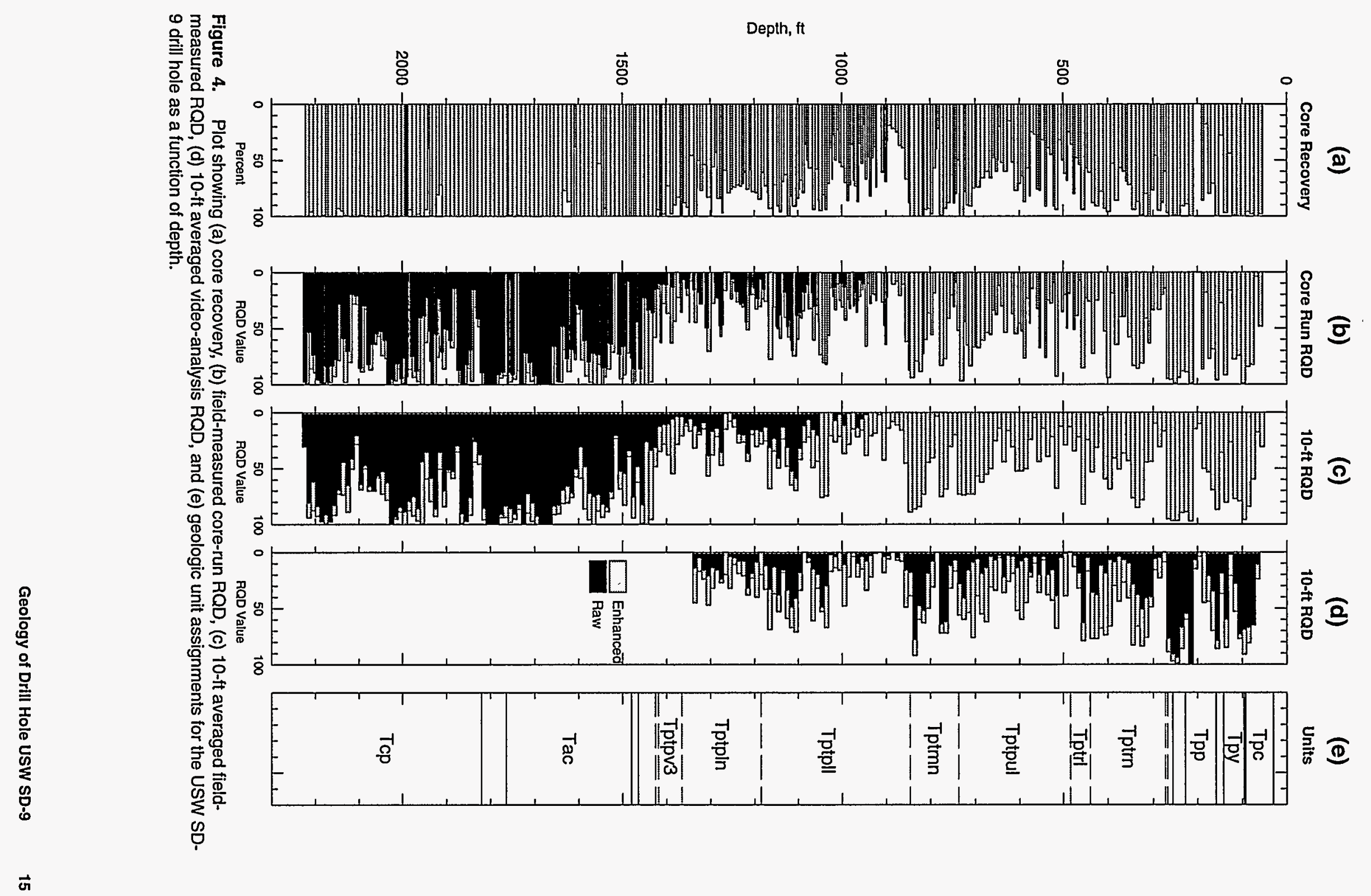


Core recovery data are only estimates. The accuracy of these estimates in reflecting the actual recovery for a core run can be quite precise for intervals of generally good recovery of essentially intact core. Accuracy diminishes markedly as the integrity of the core decreases, because loose rubble recovered in the core barrel must be approximated back to in-situ dimensions prior to measurement.

A summary of the core-recovery information is presented graphically in figure 4(a). Generally, core recovery correlates fairly well with rock type. Nonwelded intervals, such as those in the upper part of the hole above approximately $280 \mathrm{ft}(85 \mathrm{~m})$ and in the lower third of the hole below about 1450 $\mathrm{ft}(440 \mathrm{~m})$, core well and yield near 100-percent recovery. Local exceptions, such as that at $200 \mathrm{ft}$ $(60 \mathrm{~m})$, involye completely unlithified and reworked "bedded tuff" deposits that lack meaningful cohesion. Zeolitic rocks, present in the bottom one-third of the SD-9 drill hole, generally yield 100-percent recoveries as well. The densely welded tuffs of the main part of the Topopah Spring are brittle, highly fractured, and consequently yield relatively low recoveries. Nonlithophysal units appear to produce better recoveries than the lithophysal intervals. Comparison of the core runs from about 700 to $885 \mathrm{ft}$ (213 to $270 \mathrm{~m}$ ) with those immediately above and below demonstrates that some of the low core recoveries observed in the two main lithophysal zones of the Topopah Spring Tuff may be explained partially by the presence of the very large lithophysal cavities observed in down-hole video logs. In addition to producing rock rubble that may be lost during coring operations when the drill hole penetrates the weak, poorly supported margins of the cavities, the cumulative void space encountered by the drill hole may constitute a non-trivial fraction of certain intervals. Note also that the presence of these large lithophysal cavities is not limited to the more strictly defined "lithophysal zones" of Buesch and others (1996). This is particularly true for the lower nonlithophysal (Tptpln) interval. Note the marked differences in core recovery values between approximately $1200-1350 \mathrm{ft}$ and $1350-1400 \mathrm{ft}$ in figure 4(a). The deepest described large lithophysal cavity was encountered at a depth of $1354 \mathrm{ft}$ (Appendix B, log sheet 20).

\section{$R Q D$ (Rock Quality Designation)}

Measurement of RQD is also a relative mechanical process, and it is usually performed as an adjunct to measurement of core recovery. Like core recovery, RQD has been defined on a per-run basis for each drilling interval (Deere and Deere,1989). RQD is generally also reported on the basis of a standardized interval, typically 10 feet (approximately $3 \mathrm{~m}$ ). The use of a standard-length measurement interval reduces the occurrence of interspersed, wildly erratic RQD values that may be associated with numerous very short core runs (particularly in broken rock).

The procedure for determining RQD data is as follows.

1) The core is laid out in an appropriate manner as for core-recovery measurements.

2) The length of the core run is determined as for core-recovery measurements.

3) The cumulative footage of intact, whole core segments of sound rock longer than 4 inches $(100 \mathrm{~mm})$ as measured along the centerline of the core is measured using a steel tape measure. Ends that result from diagonal fracturing of the rock mass are excluded from the measurement (fig. 5). There are two alternatives for the treatment of fractures:

(a) all extant fractures are considered as breaks in the core, regardless of whether or not the fractures appear to be natural or drilling induced; or

(b) only natural fractures are considered to be breaks in the core.

4) The cumulative footage thus measured is converted to a percentage of the drilling interval and recorded to the nearest percent.

The originator of the RQD measurement system (Deere, 1963; see also Deere and Deere, 1989, p. 15,43 ) recommended that only natural breaks in the core be considered. Deere and Deere explicitly state that breaks that are obviously an artificial result of the drilling and/or core-handling process are to be discounted in the determination of "broken" core. Criteria for identifying "natural" fractures may include: fracture in-filling or mineralization; obvious non-matching sides; the 


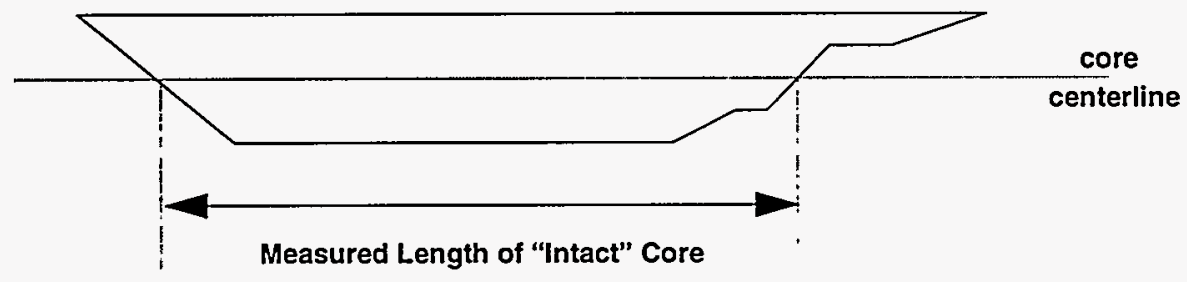

Figure 5. Conceptual sketch for measuring the length of "intact" core segments for RQD determinations. Segments must be longer than 4 inches $(100 \mathrm{~mm})$ to count toward RQD. Ends, "ears," and other segments less than 4 inches in length are not included in the length measurement.

presence of gouge, slickensides, or other structures suggestive of relative movement; and potentially other site-specific features. Criteria for induced fractures include: actual observation of core breakage during handling; absence of any fracture-filling material other than drilling mud; clean, sharp edges that fit tightly together, and breaks at $90^{\circ}$ to the core axis. If the origin of a particular break is in doubt, their procedure is to count it as a natural break, which would produce an RQD value that is conservative from a rock-stability standpoint. If all fractures are considered breaks in the core, the value that results is referred to in this report as "raw RQD." If induced fractures are discounted, the value is referred to as "enhanced RQD" or "Deere RQD."

The requirement for "sound rock" is also subjective, but it is intended (Deere and Deere, 1989, p. 16) to exclude intervals of altered, weathered, or otherwise unstable material that might conceivably be recovered "intact" (not fractured or broken). If the soundness of a particular core segment that would otherwise qualify is in doubt, it is excluded from the cumulative-length measurement for RQD determination. The intent is to be conservative from a design standpoint of estimating ground stability. In practice, such subjective decisions involving Yucca Mountain core are not an issue, as the type of alteration that typically produces "soft" yet intact core is virtually unknown from the upper portion of the volcanic section.

Measured RQD data for the individual core runs of drill hole USW SD-9 are given in Appendix $\mathrm{D}$, table $\mathrm{D}-1$. The $10-\mathrm{ft}$ composite (averaged) RQD values are in table D-2. Both raw and enhanced $\mathrm{RQD}$ values are presented in the tables. RQD values for the SD-9 drill hole are shown in graphical form in figure 4, parts (b), (c), and (d). RQD values are also included graphically on the detailed geologic log sheets in Appendix B for comparison with the geologic description.

Note that there two sources of RQD data and RQD composites. The data in table $D-1$ and the columns in table D-2 that are headed "Drilling Support" are based on actual physical measurement of the core by drilling support staff at the time of recovery of the core from the hole. The values in the columns of table D-2 that are headed "Study 8.3.1.14.2" are based on office interpretation of video images of the core that were filmed immediately upon opening of the core barrel in the field. The field-measured values benefit from direct physical observation of the core, including examination of actual fracture surfaces for the presence of mineralization and other phenomena that may bear on the issue of natural versus induced. However, the logistics of sampling the core at the rig site and preserving those samples in near-in-situ hydrologic conditions limits the time that can be spent examining a core run to a few minutes. The video-based RQD measurements, which were actually obtained as part of SCP Study 8.3.1.14.2 (Soil and Rock Properties of Potential Locations of Surface Facilities; USGS, 1991b), are not subject to this time limitation; however, these data are limited by the inability to examine the core itself physically. The values portrayed on the detailed geologic log of drill hole SD-9 (Appendix B) are the 10-foot 
composite, field-measured, enhanced (Deere) RQD values from table D-2 (column 3 ).

A confounding factor for the SD-9 drill hole is that drilling support staff did not record the raw piece-length measurements for the upper part of the hole. The procedure controlling this work at that time provided only for recording of adjusted piece length, corresponding to enhanced or original RQD as defined by Deere and Deere (1989). A revised procedure for recording both measurements became effective with core run number 163 (table D-1) beginning at a depth of $1124.4 \mathrm{ft}$ $(342.70 \mathrm{~m})$. Video-based RQD values were not

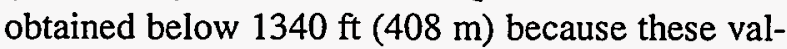
ues were developed specifically for use in design of the Exploratory Studies Facility. The deeper part of the drill hole is below this zone of short-term engineering interest.

Examination of figure 4 indicates that the differences among the various RQD values are relatively insignificant in light of the fact that RQD is a rough, preliminary estimate of rock mass integrity. Design decisions for ground support of underground openings, such as the Exploratory Studies Facility or a potential repository, are generally based on large categorical groupings of $R Q D$ values (table 5).

Table 5: RQD and Rock-Quality Descriptors [after Deere and Deere (1989)]

\begin{tabular}{cc}
\hline RQD & Description \\
\hline $90-100$ & Excellent \\
$75-90$ & Good \\
$50-75$ & Fair \\
$25-50$ & Poor \\
$0-25$ & Very poor \\
\hline
\end{tabular}

As anticipated, the core-run RQD values are noticeably more variable than the ten-foot composites. For these composite values, the enhanced or Deere RQD values are logically lower than the raw values, for which the impact of drilling and sample handling have not been discounted. Note that in some intervals, such as from 300 to $700 \mathrm{ft}$ [90-210 $\mathrm{m}$; figure $4(\mathrm{~d})$ ], the effect of ostensibly coring- induced fractures may be rather significant. Generally, the integrity of the thick welded Topopah Spring interval ( 250 to $1460 \mathrm{ft} ; 77$ to $446 \mathrm{~m}$ ) is rather poor by any measure. The presence of lithophysal cavities and of brittle, fractured, welded materials produces low values of RQD. Typically the nonlithophysal zones (270-440, 730-845, and $11907-1420 \mathrm{ft}$ ) exhibit higher values than do the lithophysal zones $(440-729,846-1187 \mathrm{ft})$. Rock quality is markedly higher in the largely nonwelded intervals above about $280 \mathrm{ft}(85 \mathrm{~m})$ and below $1420 \mathrm{ft}$ (433 m).

\section{Measured Lithophysal Cavity Information}

Quantitative information regarding the abundance of the smaller lithophysal cavities (as distinct from the abundance of lithophysae and of large cavities) is reported in Appendix E, table E-1. This data is also summarized graphically in figure $6(a)$. Core-recovery information from figure $4(a)$ is repeated in figure 6 for comparison purposes.

The data contained in table E-1 were obtained by comparing the surface area of the core and corevideo images occupied by actual cavities with standard charts for estimating mineral percentages in thin sections. Lithophysal cavities larger than the core diameter, or which were sufficiently large that the core was rubblized during the drilling process are not included in these estimates. As suggested by one of the emphasized statements in the Buesch and others quotation (see page 12), the presence of broken and unrecovered intervals has been found to be associated with what appear to be large-diameter lithophysal cavities in down-hole video images. Recovered rubble containing fragments of vapor-phase altered rock and open-space crystalline material (cavity linings of Buesch and others) confirms this remote-sensing interpretation. Note that the down-hole video images suggest that such large lithophysal cavities may be quite abundant locally: compare for example the core recovery data or RQD data (from fig. 4) with the down-hole distribution of lithophysal cavities in figure 6 .

Because of the difficulty of obtaining rigorously quantitative information on the fraction of large (greater-than-core-diameter) lithophysal cavities from the down-hole video imagery, a surrogate quantitative measure potentially indicative of these 
(a)

(b)

(c)

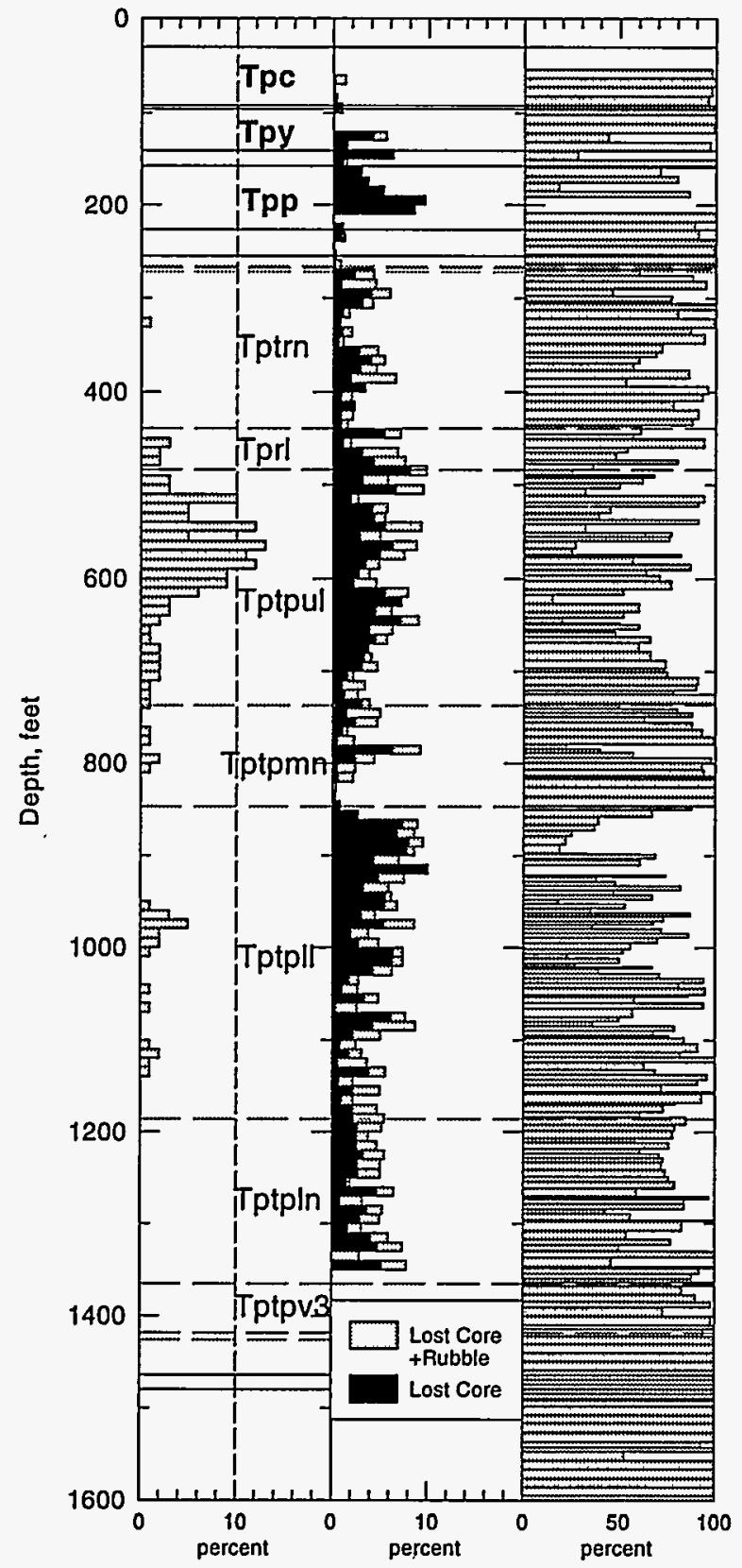

Figure 6. Graph showing (a) abundance of small lithophysal cavities, (b) core loss and core loss plus rubble zones, and (c) core recovery as a function of depth for the USW SD-9 drill hole. Selected major stratigraphic units and subdivisions of the Topopah Spring Tuff are indicated by horizontal lines (solid and dashed, respectively). large void spaces is presented for comparison in figure 6. Column (b) of the figure illustrates the percentage of lost core and the percentage of lost core plus the cumulative percentage of rubblized material for each $10-\mathrm{ft}(3-\mathrm{m})$ interval. Core recovery for individual core runs is also presented on the figure in column (c).

Although equating core loss (or core loss-plusrubble) with the fraction of large lithophysal cavity void space involves a presumption that core is not lost during drilling for any other reason, the graph of figure 6(b) does place a reasonable upper limit on the extent of development of the large lithophysal cavities. Figure 6(a) is completely consistent with the independent information shown on the detailed core logs of Appendix B. There are very few open, small lithophysal cavities in the lower lithophysal zone above a depth of about $962.6 \mathrm{ft}$ (292.38 m; log sheets 13-14 vs. sheet 15; Appendix B), and open cavities below this depth die out below about $1000 \mathrm{ft}$ ( $305 \mathrm{~m}$; sheet 15). The geologic log again describes small lithophysae with minor cavity development from about 10501070 (320-326 m; log sheet 16), and again from 1120-1170 ft (340-357 m; sheet 17). In similar fashion, figure $6(\mathrm{~b})$ is quite consistent with the record of observations of large lithophysal cavities from the down-hole video log. Large cavities are described in the log of Appendix B starting at a depth of $860 \mathrm{ft}$ (362 m; log sheet 13), at essentially the same depth where core recovery drops markedly and RQD values go virtually to zero (detail in the right-hand columns of log sheet 13). Large cavities were observed nearly to the top of the lower vitrophyre (lithostratigraphic unit Tptpv3); the bottom of the last such cavity observed in the downhole video imagery was at a depth of $1354.0 \mathrm{ft}$ $(382.20 \mathrm{~m}$; log sheet 20). Although material below a depth of $1187.0 \mathrm{ft}$ ( $361.89 \mathrm{~m}$; log sheets 17-20) is assigned to the lower "nonlithophysal" zone, it must be explicitly recognized that such named-unit assignments are secondary to the actual descriptive information contained in the geologic log (Appen$\operatorname{dix} B$ ), and that the assigned names represent an overall interpretation of the descriptive material.

\section{Fracture Information}

Fracture information has been measured during logging of the core from drill hole USW SD-9. 
Fractures are represented schematically on the geologic log sheets in Appendix B. This representation is only semiquantitative; however, it does capture much of the general style of fracturing. Fracture density is approximately shown, and fracture orientations are shown with respect to the core axis (effectively vertical at SD-9). The simultaneous presentation of fracture style with the other geologic indicators allows some understanding of controls on fracture density, orientation, and mineralization; this qualitative fracture description is available for the entire drill core. More quantitative fracture information has been acquired from detailed counting and measurement for the upper portion of the SD-9 drill core. These data have been summarized into 10 -foot depth increments, and the numeric values are presented in Appendix F, table F-1.

The quantitative fracture data are presented in figure 7. The fracture density log shown in part (a) of figure 7 distinguishes coring- and handlinginduced fractures from natural fractures. The "natural" category actually includes both natural fractures and fractures of "indeterminate" origin. Part (b) of figure 7 portrays fracture orientations by 30 degree increments; a somewhat expanded frequency scale has been used to allow better visualization of the different orientation classes. The appendix contains a more detailed 10-degree categorization of fractures. Neither the tabular fracture data nor the illustrations in this report has been corrected for the well-known effect of fracture dip on the numbers of fractures observed in a vertical borehole (Scott and others, 1983):

$$
F_{c}=\frac{F_{m}}{\cos \alpha}
$$

where $F_{c}$ is the corrected fracture frequency adjusted for fracture dip, $\alpha$, and $F_{m}$ is the measured fracture density. The impact of this cosine-correction factor can be relatively large in selected intervals.

Part (c) of figure 7 provides a breakdown of clean fractures in contrast to fractures that contain some degree of mineralization or veining. Mineralization is most common in the uppermost part of the drill hole, principally associated with the columnar subzone of the Tiva Canyon Tuff and with the crystal-rich vitric and nonlithophysal zones of the Topopah Spring Tuff. Note that both of these intervals are immediately below relatively porous materials: surface colluvium and the Paintbrush nonwelded interval, respectively. Mineralized fractures are least abundant in the lithophysal zones of the Topopah Spring, and they appear to be most extensively developed in the lower Topopah near the location of the perched water body. Perched water was encountered in SD-9 at a depth of $1353 \mathrm{ft}$ (412.5 m) (see also page 7).

RQD values and core recovery information are also shown in figure 7 for comparison. Although rock quality and RQD values should be inversely related to fracture density, there is no clear overall correspondence between the more highly fractured intervals and intervals of low RQD (presumably containing highly broken rock). In fact, in some intervals there appears to be a positive relationship, with lower RQD values [profile (d)] in those zones with the fewest natural fractures [profile (a)]. Examination of figure 7 [columns (a), (d) and (e)] also suggests that there is a positive correlation between core recovery and both fracture density and RQD. The cause of this correlation is that fractures cannot actually be measured and counted in core that is not recovered. Measurement of RQD is affected in a similar manner in that missing core adds zero footage to the cumulative footage of core segments greater than four inches.

Figure 8 presents the results of several different attempts to adjust the measured fracture density data for the impacts of "unobservable" core. Table F-1 contains a summary of "lost core" for each 10foot composite interval; these values were determined through office analysis of the video images of the recovered core, and are not directly comparable to the core recovery data measured by drilling support staff (table C-1). Additionally, table F-1 contains the cumulative footage for each depth increment that was logged as "rubble zone." The question of the number of actual, in-situ fractures represented by an interval of "rubble" is problematic. Certainly some disaggregation of rock is associated with the drilling process. However, it is possible to place some limits on the number of real fractures that may be represented by logged rubble zones. 
(a)

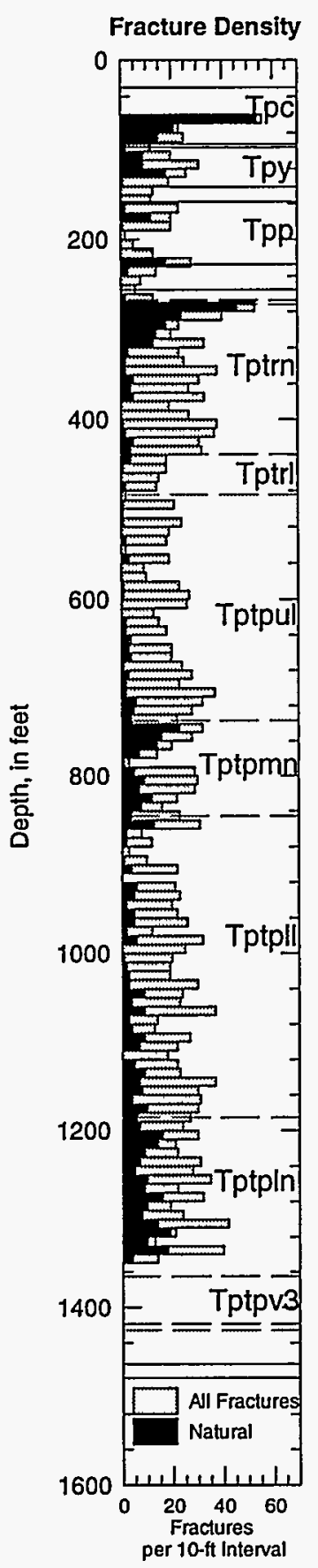

(b)

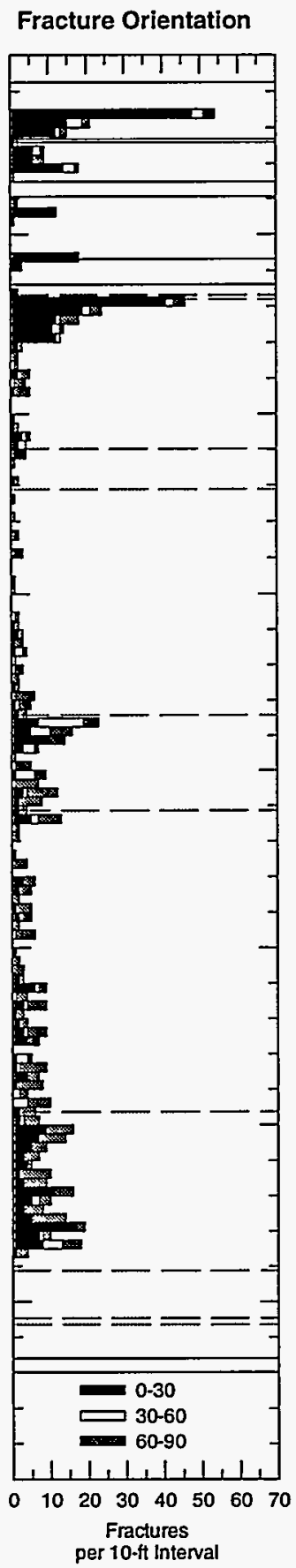

(c)

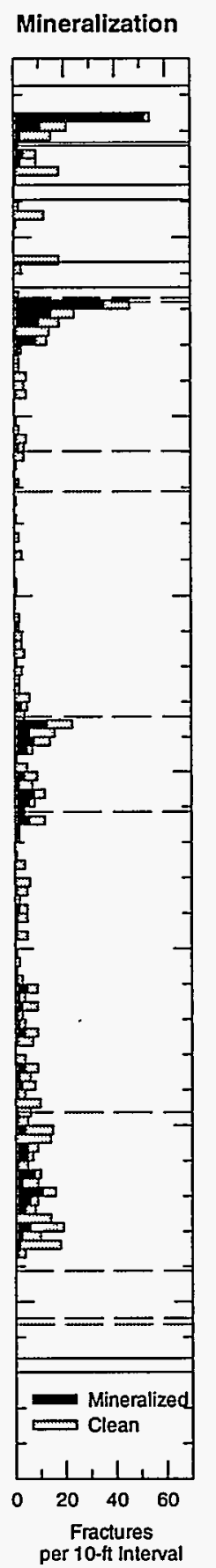

10-ft Interval (d)

(e) 10-ft RQD Core Recovery
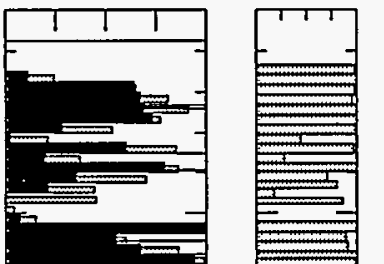

들
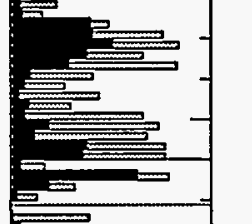

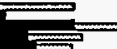

$\rightarrow=$

$=$

e

$=$

를

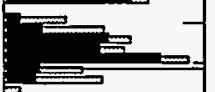

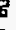

$-$

e

扈

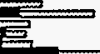

$=5$
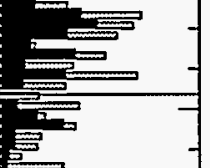

를
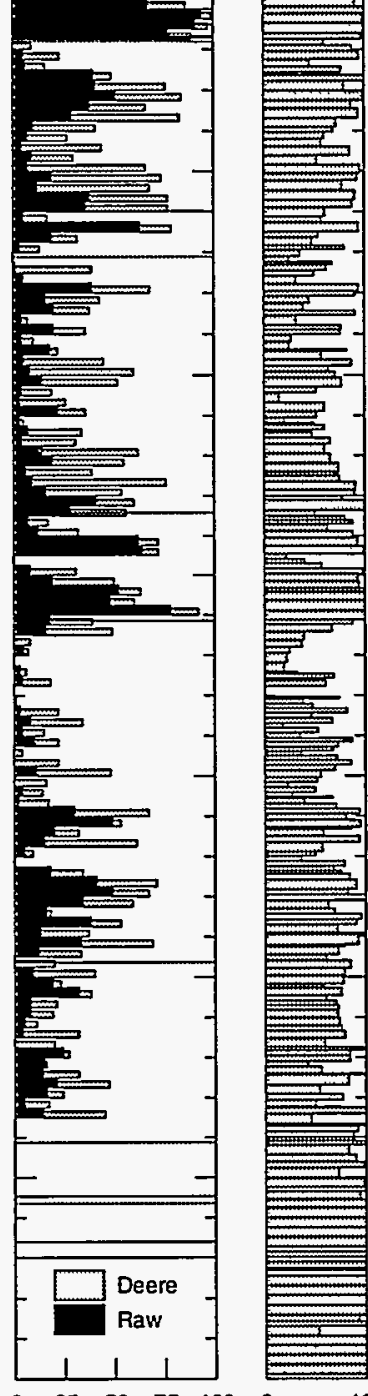

$=$
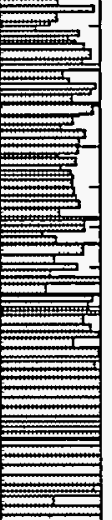

$\begin{array}{llllllllll}0 & 25 & 50 & 75 & 100 & 0 & 100\end{array}$

Figure 7. Graphs showing (a) measured fracture density, (b) fracture orientation (dip), (c) mineralized fractures, (d) 10-ft video-analysis RQD, and (e) core recovery for the upper portion of the USW SD-9 drill hole. Solid horizontal lines in (1) indicate top and bottom contacts of the Tiva Canyon and Topopah Spring Tuffs and the top of the Calico Hills Formation. Dashed horizontal lines are contacts of Topopah Spring zonal units. 
(a)

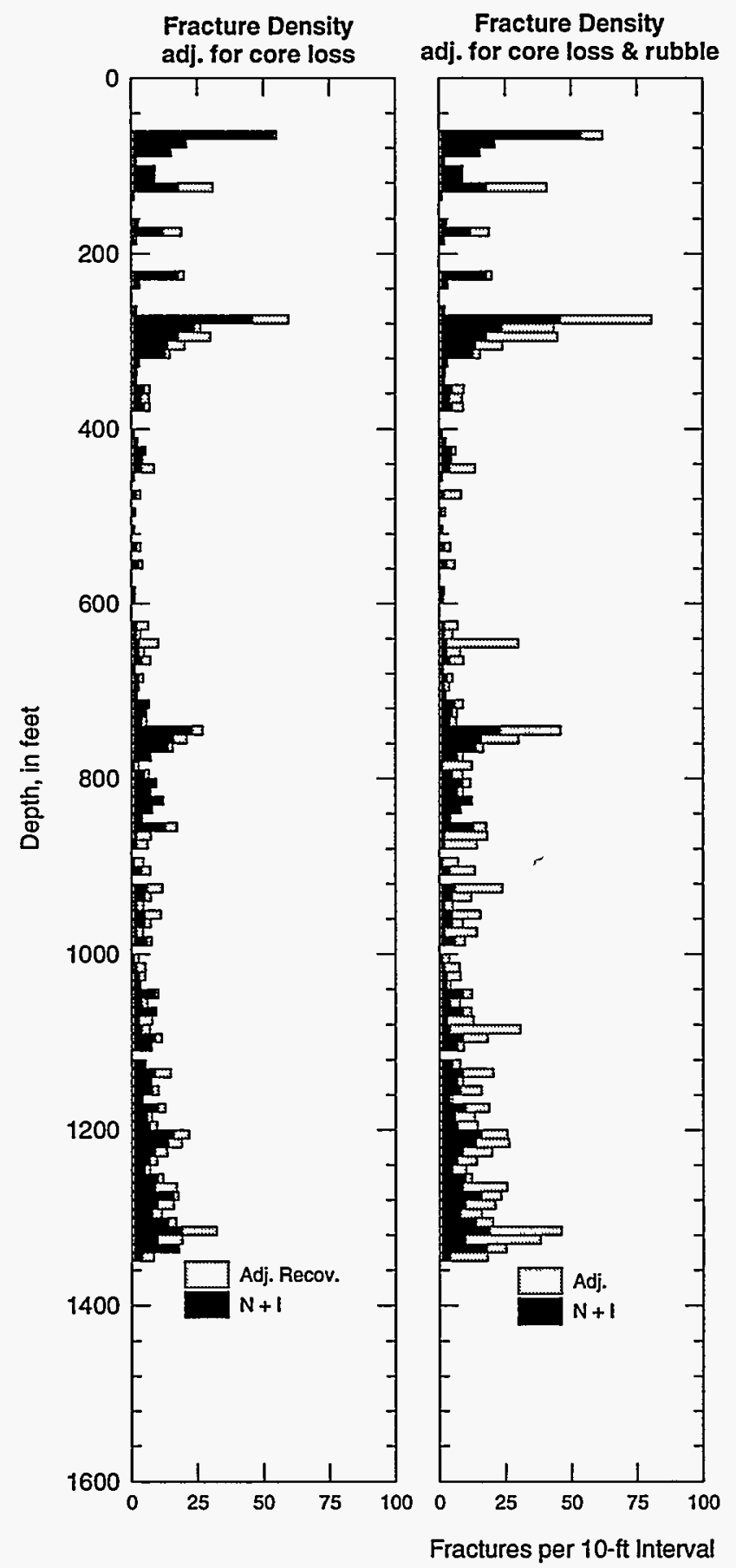

(b)

(c)

Fracture Density

adj. for $D_{r z}$

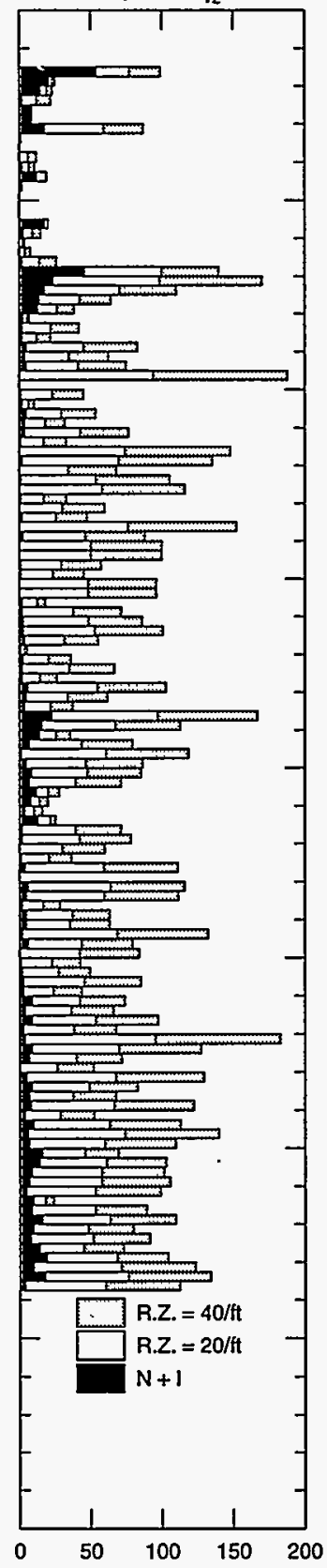

Figure 8. Graphs showing fracture density adjusted for measurement effects of lost core and rubble zones. (a) Adjusted for core recovery only. (b) Adjusted for core recovery and length of rubble zones. (c) Adjusted for core recovery and for intensity of fracturing in rubble zones. See text for method of calculation. Note expanded frequency scale in (c). 
Part (a) of figure 8 presents both the number of "natural" (natural plus indeterminate) fractures logged from the core video tapes and the likely number of fractures that would have been logged had there been 100 percent core recovery. The formula for this adjustment is as follows:

$$
N_{c l}=\frac{N+I}{(10-C L) / 10},
$$

where $N_{c l}$ is the number of fractures per $10-\mathrm{ft}$ interval adjusted for core loss, $N+I$ is the counted number of natural and indeterminate fractures, and $C L$ is the cumulative footage of lost core in the $10-\mathrm{ft}$ interval.

Equation (2) adjusts only for unrecovered intervals. Part (b) of figure 8 attempts an additional first-order correction for the effect of fractures that could not be logged individually because the core was rubblized. This correction is:

$$
N_{c r}=\frac{N+I}{(10-(C L+R Z)) / 10},
$$

where $N_{c r}$ is now the number of fractures adjusted for both core loss and rubble zones and $R Z$ is the cumulative footage of those rubble zones in the relevant 10-ft depth interval.

Both equations (2) and (3) amount to an assumption that the density of fracturing present in the in-place rock for those parts of the core that were either lost or rubblized is essentially the same as the density of fracturing present in the core that was recovered. This assumption of equal fracture densities in both lost and recovered core probably is not conservative from a rock-mass stability standpoint. One might anticipate lost (or rubblized) intervals to have been more densely fractured than material that maintained its integrity to some extent during the mechanical agitation of drilling and core retrieval.

A more hypothetical and less-conservative adjustment of the measured fracture densities has been attempted in part (c) of figure 8. For this adjustment, a rubble zone is considered to consist of an arbitrary number of fractures per foot of rubble. The total number of fractures per $10-\mathrm{ft}$ depth increment is then simply the core-recoveryadjusted fracture density, $N_{c l}$, plus the footage of rubble times this assumed fracture density:

$$
N_{r z}=N_{c l}+D_{r z} \times L_{r z}
$$

Here, $N_{r z}$ is the desired total number of fractures, adjusted for rubble-zone fracture density, $L_{r z}$ is the cumulative length of rubblized material, and $D_{r z}$ is either 20 or 40 fractures per foot of rubble. The values of 20 and 40 fractures per foot originate from the criteria that drilling support staff used to distinguish the intervals that would be classified as rubble zones. An initial value of 40 fractures per foot as the criterion was later reduced to 20 per foot after it became evident that much of the rock at Yucca Mountain was highly fractured. Note that these values were selected merely to eliminate the time-consuming recording of each individual fracture separately during the logging of highly broken intervals, and that neither value for $D_{r}$ may necessarily be correct for any particular interval of core. Mechanical disaggregation of some otherwiseintact core is anticipated during the course of drilling. Additionally, the presence of large lithophysal cavities in parts of the welded-tuff sequences means that some intervals of lost core may, in fact, represent actual void space in the rock; such void space is not "fractured," per se. Unsupported (but unfractured) rock, particularly near the upper margins of large lithophysal cavities, may be mechanically broken by pressure of the advancing drill string and dropped into the cavity to be recovered as "rubble" when the coring assembly advances to the bottom of the cavity.

\section{Framework Hydrologic Properties}

\section{Laboratory Techniques}

Core samples were obtained at regular intervals for laboratory measurements of framework material properties. "Framework material properties" are defined in Study Plan 8.3.1.4.3.1 (Rautman, 1993) as porosity, bulk and particle density, and saturated hydraulic conductivity. Water contents were also determined and used to compute saturation. Measurement of framework material properties was carried out in collaboration with SCP Study 8.3.1.2.2.3 (USGS, 1991a).

Approximately 580 eight-inch long core samples were collected for hydrologic analyses on a nominal 3-ft, regular sampling interval. Each core sample was subdivided into two subsamples. A 2- 
inch long core fragment was placed in a metal container and sealed within minutes of core retrieval from the hole, An immediately adjacent 6-inch subsample was preserved in a Lexan ${ }^{\mathrm{TM}}$ tube that was capped and sealed with duct tape. The intent was to preserve in-situ moisture contents as closely as possible and especially to prevent dry-out of the core and subsequent irreversible changes in pore geometry caused by desiccation of clays and zeolites. Such changes have been demonstrated to affect permeability measurements irreversibly.

Porosity, bulk density, particle density, and water content were determined in the laboratory for the hermetically sealed 2 -inch core fragments. Separately, a subset of the 6-inch core samples were subcored to produce specimens suitable for measurement of saturated hydraulic conductivity. Core plugs were trimmed using a small diamond saw to approximate right-circular cylinders approximately $2.5 \mathrm{~cm}$ in diameter and $3-10 \mathrm{~cm}$ long prior to testing. Porosity, bulk density, and particle density were also measured for these prepared specimens.

Water content was determined by gravimetry and is reported as cubic centimeters per cubic centimeter. Porosity $(\phi$, in cubic centimeters per cubic centimeter and expressed as a decimal fraction for simplicity), bulk density ( $\rho_{b}$, in grams per cubic centimeter), and particle density ( $\rho_{p}$, in grams per cubic centimeter) were determined using gravimetry and Archimedes' principle to determine sample volume. There were two departures from the classical application of this technique. First, the samples were initially saturated with carbon dioxide gas by introducing the gas into an evacuated bell jar containing the samples; this process, which was repeated three times, prevents air entrapment in small internal pores within the densely welded tuff samples because the $\mathrm{CO}_{2}$ is water-soluble. The samples were then saturated with degassed distilled water under a vacuum. Scoping studies have indicated that saturated weights did not change meaningfully following a single iteration of this vacuum-saturation process, even with the addition of a pressure-saturation step. Second, the samples were dried in a relative-humidity ( $\mathrm{RH})$-controlled oven at $60^{\circ} \mathrm{C}$ and 65 -percent RH (after concepts proposed by Bush and Jenkins, 1970), rather than at $105^{\circ} \mathrm{C}$ and associated ambient $\mathrm{RH}$. Soeder and others (1991) advocated the use of a lower temperature, humidified technique, not only to preserve water present in the crystal structure of any clays or hydrated minerals (such as zeolites), but also to retain water loosely bound to grain surfaces which is otherwise unavailable for unsaturated flow. The selected RH of 65 percent translates to an estimated residual-saturation pressure for Yucca Mountain samples of approximately -700 bars (L.E. Flint, U.S. Geological Survey, written communication, 1996).

Particle density, as used in this report, is similar to the more commonly reported grain density. However, because particle density is a property computationally derived from intact core samples, totally encapsulated void space (which is inaccessible to water flow) is not considered. Particle density is almost invariably lower than a grain density determination obtained by crushing the rock and measuring the change in total volume. Particle density will approach grain density for rocks that have little totally encapsulated pore space. Bulk-property measurements were repeated after more conventional sample drying at $105^{\circ} \mathrm{C}$ to allow for comparison with other reported data (ASTM, 1990). Sample weights were reduced to the desired bulk properties as follows.

$$
\begin{gathered}
\rho_{b}=\frac{\text { dry weight }}{\text { bulk volume }}, \\
\phi=\frac{\text { pore volume }}{\text { bulk volume }} \text {, and } \\
\rho_{p}=\frac{\text { dry weight }}{\text { bulk volume - pore volume }} \text {, where (7) }
\end{gathered}
$$

pore volume $=$

$$
\frac{\text { (saturated weight }- \text { dry weight) }}{\rho_{w}}
$$

and $\rho_{w}$ is the temperature-adjusted density of water (in grams per cubic centimeter). Bulk volume is simply the weight of the fully-saturated sample submerged in water (by Archimedes' principle). Volumetric water content (VWC) was determined as:

$\mathrm{WVC}=$

$$
\left(\frac{\text { saturated weight }- \text { dry weight }}{\text { dry weight }}\right) \cdot \rho_{b}
$$


Saturated hydraulic conductivity, $K_{s}$, in meters per second and usually presented as $\log _{10} K_{s}$ in this report, was measured using a constant-head method. The core plugs were saturated with tap water using the vacuum evacuation/ $/ \mathrm{CO}_{2}$ flooding technique. Each sample was encased in heavy vinyl tubing and placed in a chamber (Hassler permeameter) that produced a hydraulic confining pressure $(0.41-0.55 \mathrm{MPa})$, slightly exceeding the gradient across the sample, to prevent escape flow around the sides of the sample. Confining pressures of this magnitude do not affect the permeability of the rock, especially since welded samples have compressive strengths on the order of 100 MPa (Nimick and Schwartz, 1987). A separate system provided J-13 tap water under pressure for flow through the sample. Effluent was weighed on a top-loading balance and the mass was recorded as a function of time as the water left the sample. Saturated hydraulic conductivity was computed from Darcy's law:

$$
K_{s}=\frac{Q}{A} \cdot \frac{L}{\Delta H} \quad,
$$

where $Q$ is the quantity of water flowing through the sample per unit time $\left(\mathrm{cm}^{3} / \mathrm{sec}\right), A$ is the crosssectional area of the sample core plug $\left(\mathrm{cm}^{2}\right), \Delta H$ is the change in total head $(\mathrm{cm})$ across the sample, and $L$ is the length $(\mathrm{cm})$ of the core plug. Note that $\mathrm{K}_{\mathrm{s}}$ has been converted to units of meters per second in all tables and figures in this report.

\section{Material-Properties Data}

Results of the laboratory material-properties determinations are presented in Appendix G. Table G-1 contains bulk properties (porosity, bulk density, particle density) and initial water contents for both relative-humidity oven-dried and $105^{\circ} \mathrm{C}$-dried samples. Saturated hydraulic conductivity measurements are presented in table G-2. Separate porosity measurements were also obtained from the permeability-plug samples. These supplemental porosity data are listed in the table of conductivity values.

Data from table G-1 are presented graphically in $\log$ format in figure 9 . The figure includes both the relative-humidity and $105^{\circ} \mathrm{C}$ data, which are represented by different symbols. Note that the two values for each sample are essentially identical throughout most of the upper portion of the drill hole. Major differences in the properties measured by these two techniques occur only in the presence of hydrated minerals, such as clays and particularly zeolites. Generally, the picture that emerges from the material-properties data is reflective of the ther$\mathrm{mal} / \mathrm{mechanical}$ units identified in table 4 . The saturated hydraulic conductivity data from table G-2 are presented in graphical format in figure 10, together with the corresponding porosity measurements from these subcored sample plugs. Note that samples identified as exhibiting no measurable flow through the Hassler permeameter have been assigned an arbitrary $K_{s}$ value for plotting purposes of $10^{-14} \mathrm{~m} / \mathrm{sec}\left(\log _{10} K_{s}=-14\right)$. Porosity and bulk density values from table G-1 are also illustrated on the $\log$ sheets of Appendix B, as are values for approximate in-situ saturation.

The major lithologic subdivisions of the rock column penetrated by drill hole USW SD-9 can be identified in the material-property profiles shown in figure 9. The unsampled material to a depth of approximately $50 \mathrm{ft}(15 \mathrm{~m})$ corresponds to the drilled interval consisting of drill-pad fill and colluvial deposits [to a depth of $53.6 \mathrm{ft}(16.34 \mathrm{~m})$ as indicated in the geologic log of Appendix B]. The welded portion of the Tiva Canyon Tuff is represented by a few measured porosity values of approximately 0.10 , down to a depth of $55.7 \mathrm{ft}$ $(16.98 \mathrm{~m})$. Below this depth, porosity values increase progressively through the lower vitric zone of the Tiva Canyon (the shardy-base interval; Istok and others, 1994), and they remain high $(0.30-0.50)$ through the interval comprising the base of the Tiva Canyon Tuff, the Yucca Mountain and Pah Canyon Tuffs (and associated bedded tuffs), and the nonwelded subzone of the upper vitric zone of the Topopah Spring Tuff. The bottom of this latter subzone is at $266.1 \mathrm{ft}(81.13 \mathrm{~m})$, where the porosity decreases abruptly to only a few percent. Welded materials with porosities generally less than $0.10-0.12$ form the bulk of the remainder of the Topopah Spring Tuff, extending through the base of the basal vitrophyre subzone of the lower vitric zone (Tptpv3) at $1418.7 \mathrm{ft}(432.53 \mathrm{~m})$, in which the values again drop abruptly to nearly zero. 

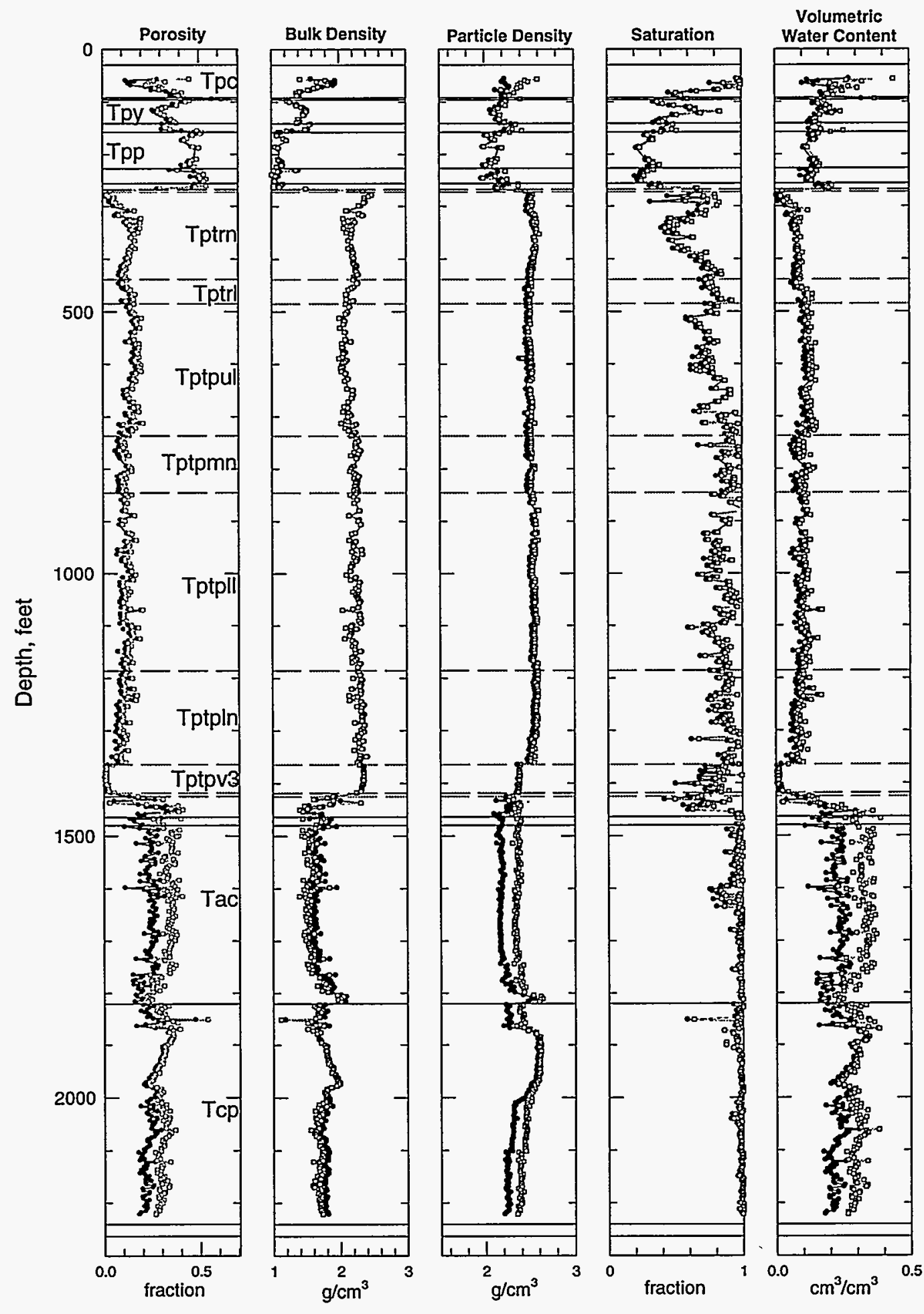

Figure 9. Porosity, bulk density, particle density, saturation, and water content profiles of core samples collected from the USW SD-9 drill core. Solid circles-relative-humidity oven-dried samples; open squares$105^{\circ} \mathrm{C}$-dried samples. Solid horizontal lines indicate top and bottom contacts of the Tiva Canyon and Topopah Spring Tuffs, the Calico Hills Formation, and the Prow Pass Tuff. Dashed horizontal lines are contacts of Topopah Spring zonal units. 


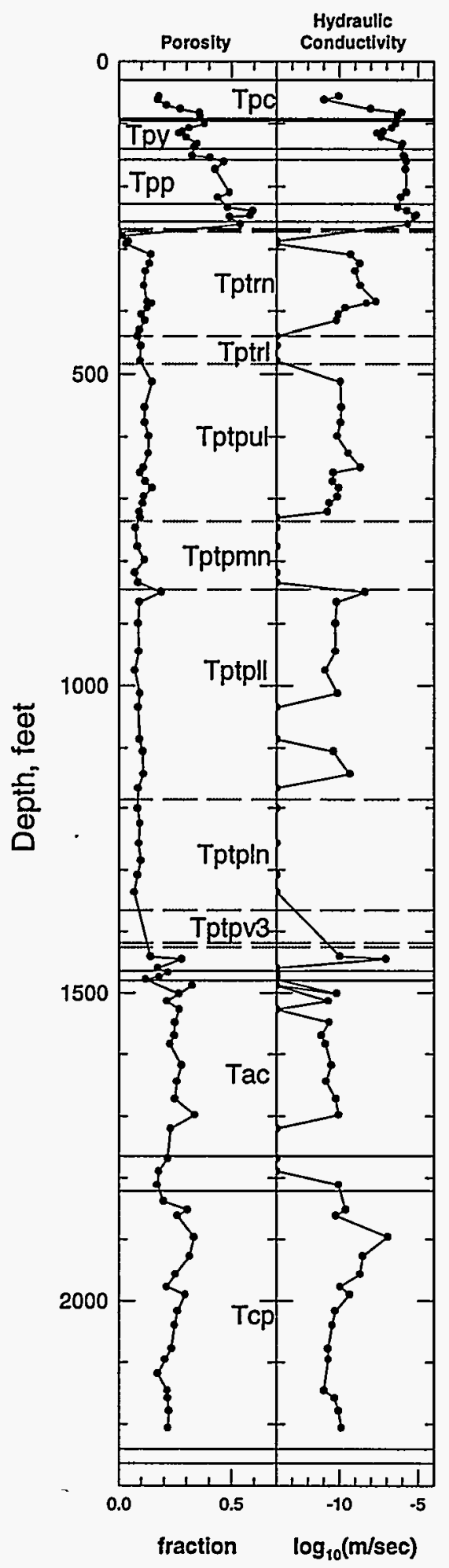

Figure 10. Porosity and saturated hydraulic conductivity profiles of core samples collected from the USW SD-9 drill core. Solid horizontal lines indicate top and bottom contacts of the Tiva Canyon and Topopah Spring Tuffs, the Calico Hills Formation, and the Prow Pass Tuff. Dashed horizontal lines are contacts of Topopah Spring zonal units.
The lowermost zones of the Topopah Spring Tuff exhibit a general increase in porosity and constitute a largely nonwelded interval (including the pre-Topopah Spring bedded tuff) that extends to approximately $1479.9 \mathrm{ft}(451.19 \mathrm{~m})$. The two porosity values begin to diverge markedly at approximately $1450 \mathrm{ft}(440 \mathrm{~m})$, representing the presence of zeolitized materials in the underlying Calico Hills Formation. The dichotomy between the relative-humidity dried samples and their $105^{\circ} \mathrm{C}$-dried counterparts is particularly well displayed by the particle density data (center profile in figure 9). The base of the Calico Hills Formation occurs at $1820.7 \mathrm{ft}(555.09 \mathrm{~m})$, although the most prominent change in porosity is associated with the bedded tuff and basal tuffaceous sandstone units of the Calico Hills [1764.4-1820.7 ft (537.93-555.09 $\mathrm{m})$ ]. The remainder of the hole consists of ash-flow units of the Prow Pass Tuff. These units are generally zeolitized, as indicated by separation of the relative-humidity and $105^{\circ} \mathrm{C}$ data, with the exception of an interval from approximately 1870-2000 $\mathrm{ft}$. This interval corresponds approximately to ashflow unit 3 (Тcp3), from 1868.7 to $2015.8 \mathrm{ft}$ (5690.73-614.57 m; log sheets 27-29, Appendix B). The geologic description of this interval notes the presence of vapor-phase mineralization and slight welding. A somewhat poorly defined and strongly asymmetric $\subset$-shaped welding profile can be identified through this interval. The $c$ is reversed and more prominent in the particle-density profile (fig. 9).

A few of the internal zones of the Topopah Spring Tuff can be identified within the thick welded portion of this unit. Notably, the thin vitrophyre subzone (the "caprock" vitrophyre; Tptrv1) of the upper vitric zone is easily identifiable by its particularly low porosity values ( 0.05 or less) at approximately $270 \mathrm{ft}(82 \mathrm{~m})$. The much thicker basal vitrophyre subzone of the lower vitric zone (Tptpv3) is also easily identified by the $50-\mathrm{ft}$ (15$\mathrm{m}$ ) interval near $1400 \mathrm{ft}$ ( $425 \mathrm{~m}$ ) of uniformly low (less than 0.05 ) porosity values. Note also that the basal vitrophyre subzone also exhibits uniform and distinctly lower values of particle density because of the glassy rock type. A suggestion of lower particle densities is associated with the caprock vitrophyre as well. 
With the exception of a part of the upper Topopah Spring interval, the majority of the many zones and subzones identified within the Topopah Spring Tuff (table 1) are essentially indistinguishable in the porosity profile. The same holds true for the other bulk-property profiles as well. The exceptions include part of the crystal-rich nonlithophysal zone (Tptrnl) at approximately 325 to $400 \mathrm{ft}(100$ $120 \mathrm{~m}$ ) and an interval within the upper lithophysal zone (Tptrl and Tptpul) from approximately 450 to $650 \mathrm{ft}(140-200 \mathrm{~m})$. Both of these intervals appear to exhibit somewhat higher porosity values ( 0.10 to as much as 0.20 ).

Saturation and initial water content data are also presented in figure 9. Water contents (righthand-most column) invariably are higher in the nonwelded intervals above about $200 \mathrm{ft}(60 \mathrm{~m})$ and below $1450 \mathrm{ft}(440 \mathrm{~m})$. There is simply more void space in these materials to contain moisture. Note that a non-negligible fraction of the total water content of the zeolitic samples, those obtained from below about $1450 \mathrm{ft}(440 \mathrm{~m})$, consists of weakly bound water that is driven off with heating above $105^{\circ} \mathrm{C}$. Saturation values are also portrayed graphically on the log sheets of Appendix B.

Saturations are high in the very near-surface samples immediately below surficial colluvium, most likely because of the influence of near-surface infiltration. Saturations generally decrease down hole through the nonwelded PTn interval and then increase progressively through the thick Topopah Spring Tuff welded section. Exceptions to this general trend can be related directly to lower porosities in the partially welded zone within the Yucca Mountain Tuff from about 100 to $120 \mathrm{ft}$ (30$36 \mathrm{~m}$ ), and to the relatively sharp increase in porosity just below the caprock vitrophyre of the Topopah Spring Tuff at approximately $300 \mathrm{ft}(90$ $\mathrm{m})$. Saturations approach 1.0 at about $700-900 \mathrm{ft}$ (210-275 $\mathrm{m}$ ) in the less vapor-phase altered, lowerporosity middle nonlithophysal zone, and again at approximately $1300 \mathrm{ft}(396 \mathrm{~m})$. Perched water was first encountered at $1353 \mathrm{ft}(412.5 \mathrm{~m})$, although the core had been described in drilling reports as "moist" beginning at approximately $1308 \mathrm{ft}$ $(398.78 \mathrm{~m})$. Core saturations decrease in samples obtained from immediately above and within the basal vitrophyre subzone. Samples from below the basal vitrophyre in the lower part of the preTopopah Spring bedded tuff are essentially fully saturated, although an interval of noticeably lower saturations is present from roughly 1600 to $1625 \mathrm{ft}$ (487-495 m). An explanation for this decrease in water content is not immediately apparent. The regional water table was encountered at a depth of $1877 \mathrm{ft}(572.26 \mathrm{~m})$.

\section{Geophysical Log Data}

Geophysical logging activities were conducted in drill hole USW SD-9 on July 13, 1995 to a depth of approximately $1500 \mathrm{ft}(450 \mathrm{~m})$. The five geophysical surveys included: (1) compensated density-gamma ray log, (2) epithermal neutron porosity-gamma ray $\log$, (3) dual induction-gamma ray $\log$, (4) dielectric propagation-gamma ray log, and (5) oriented 4-arm caliper. Drill-hole deviation data, including borehole azimuth and inclination, were also recorded. Note that the lower portion of SD-9 (below approximately $1500 \mathrm{ft}$ or $450 \mathrm{~m}$ ) had not been logged as of December 1994. The majority of the geophysical log traces are shown in figure 11. Because the geophysical logs consist of digital data on $0.5-\mathrm{ft}(0.15-\mathrm{m})$ spacings, this information is not presented in an appendix to this report. The actual trace values can be obtained from the Yucca Mountain Project records facilities using data-tracking number (DTN) TWUSWSD9000095.001.

\section{Density Log Response}

The density log [fig. 11(a)] displays the expected responses both to welding and to the development of lithophysal cavities. Bulk density values drop between depths of 67 and 80 feet (20.43-24.39 m) as the logging tool passed from the densely welded lower nonlithophysal zone of the Tiva Canyon Tuff through the progressively less-welded material of the vitric zone; Istok and others have documented continuously changing bulk density values in this shardy base interval. The bedded tuff (Tpbt4) separating the Tiva Canyon tuff from the underlying Yucca Mountain tuff at about $92-95 \mathrm{ft}(28-29 \mathrm{~m})$ exhibits a low bulk density. A small increase in density is recorded on the log through the slightly welded middle portion of the Yucca Mountain Tuff between 105 and 130 feet (32.01-39.63 m). Density values decrease 

(a)
(b)
(c)
(d)
(e)

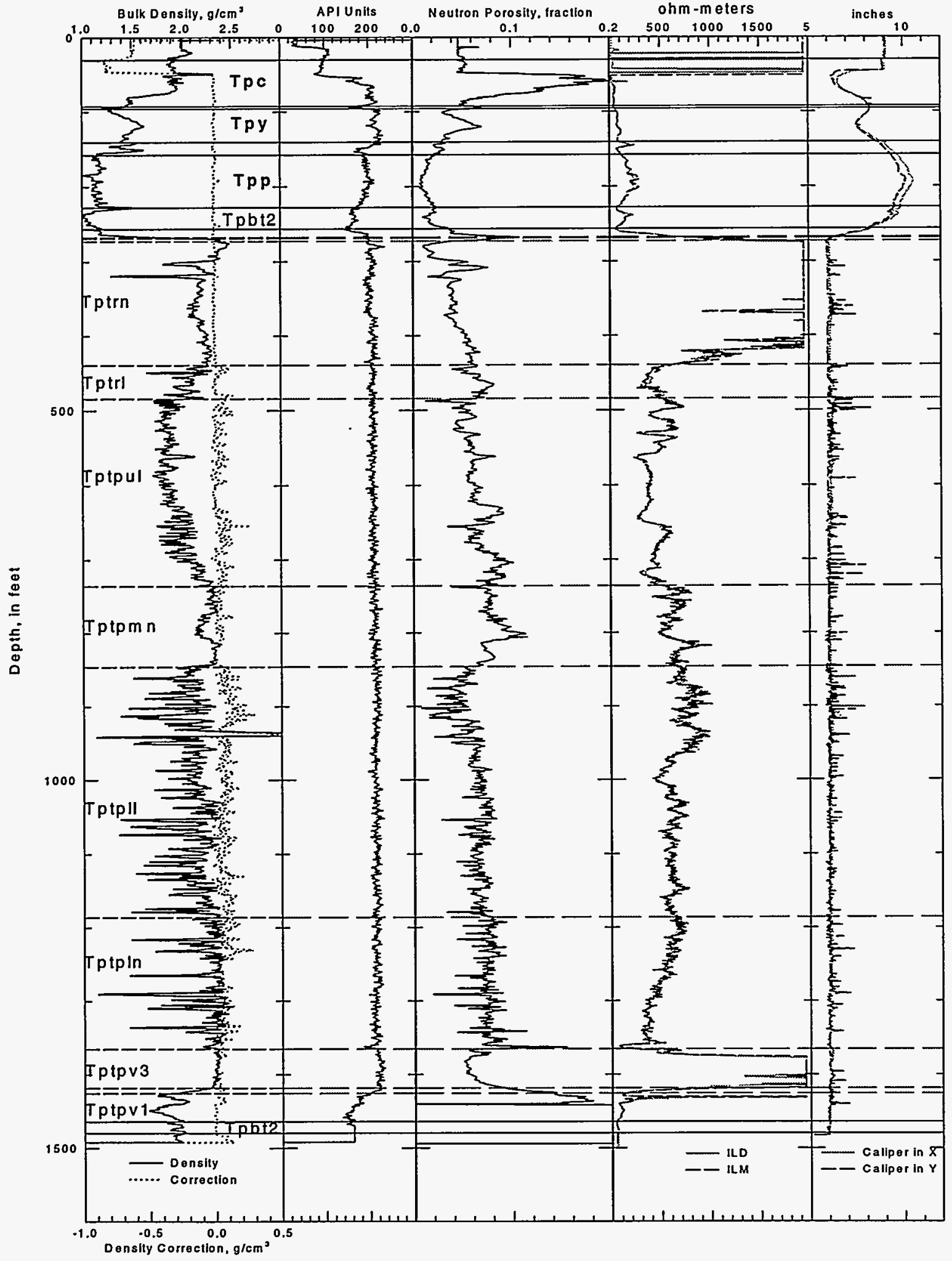

Figure 11. Geophysical log traces from the USW SD-9 drill hole: (a) density log; (b) gamma-ray log; (c) epithermal neutron porosity log; (d) induction log; and (e) caliper log. Log trace data from DTN TMUSWSD9000095.001 
through the bedded tuff underlying the Yucca Mountain Tuff (Tpbt3) to very low values of bulk density (1.15 g/ $\mathrm{cm}^{3}$ and less) in both the Pah Canyon tuff and its underlying bedded tuff (Tpbt2).

The density-log values increase at a depth of about $250 \mathrm{ft}(76 \mathrm{~m})$, corresponding to the bottom of the pre-Pah Canyon bedded tuff, and at approximately $265 \mathrm{ft}(81 \mathrm{~m})$, density increases abruptly to nearly $2.5 \mathrm{~g} / \mathrm{cm}^{3}$ as the tool passed nonwelded-towelded transition located slightly below the stratigraphic top of the Topopah Spring Tuff. The density trace continues to indicate high bulk density values through the densely welded upper nonlithophysal zone of the Topopah Spring tuff from 272.1-439.2 feet (82.9-133.9 m). The upper lithophysal zone is well expressed in the density log response as the presence of large lithophysal cavities reduces the overall bulk density of the densely welded rock. Note that bulk density values indicated by the geophysical tool response (less than $2.0 \mathrm{~g} / \mathrm{cm})^{3}$ are slightly but consistently lower than the laboratory-measured values of bulk density for equivalent depths reported in Appendix G (generally slightly greater than $2.0 \mathrm{~g} / \mathrm{cm}^{3}$ ).

Bulk density values increase within the middle nonlithophysal zone from 730 to $845 \mathrm{ft}$ (220-260 $\mathrm{m}$ ), although short intervals (largely obscured by the compressed vertical scale of figure 11) of noticeably lower density within the upper part of this zone are attributed to widely spaced, large lithophysal cavities such as were observed in the down-hole video images. Lower density values also characterize the lithophysae-bearing subzone between depths of 788.1 and 812.5 feet $(240.27$ to $247.71 \mathrm{~m}$ ). The trace of the density log through the lower 33.3 feet $(10.06 \mathrm{~m})$ of the middle nonlithophysal zone is relatively flat, which is consistent with the general absence of large lithophysal cavities in video images from this section and the higher core recoveries noted in figure 4(a).

At the top of the lower lithophysal zone, density values drop sharply and vary markedly in a somewhat erratic manner; this log response appears to reflect the prominent development of large lithophysae in this part of the densely welded section. This extreme variation in log density continues downward through the lower lithophysal zone, as described from core, into and through the lower nonlithophysal zone. The density log values stabilize at approximately the upper boundary of the lower vitrophyre unit at about 1365.0 feet (416.16 m; log sheet 20, Appendix B). This response pattern appears to be the result of the continued presence of widely-spaced, large lithophysae noted in the borehole video survey. Bulk density values decrease slightly through the lower vitrophyre unit, but then decrease rapidly (and progressively) from about 2.3 to $1.7 \mathrm{~g} / \mathrm{cm}^{3}$ through the gradationally "partially" welded zone above the nonwelded basal unit of the Topopah Spring Tuff.

\section{Gamma-Ray Log Response}

The gamma-ray logging tool responds principally to the presence of radioactive potassium $\left({ }^{40} \mathrm{~K}\right)$ in the whole rock. The log response [fig. 11(b)] indicates lower count rates (API units) above a depth of roughly $50 \mathrm{ft}(15 \mathrm{~m})$, which corresponds approximately to the contact of surficial alluvial deposits with bedrock welded tuff of the Tiva Canyon. Below this depth, the gamma-ray log trace is generally unremarkable, reflecting a generally uniform potassium content. Noticeable low count-rate spikes occur at depths of about 95 and $150 \mathrm{ft}$ ( $29 \mathrm{~m}$ and $46 \mathrm{~m}$, respectively). A broader interval of low gamma-ray values is present between about 240 and $260 \mathrm{ft}(73-79 \mathrm{~m})$. These gamma-ray lows correspond approximately to the "bedded-tuff" intervals underlying the Tiva Canyon, Yucca Mountain, and Pah Canyon Tuffs, respectively. Presumably, these reworked intervals were weathered sufficiently that some of the radioactive (and non-radioactive) potassium was leached from the rock.

\section{Epithermal Neutron Porosity Log Response}

The neutron-porosity log responds principally to the presence of water (hydrogen atoms) in the rock. Higher "porosity" values indicate greater absorption of neutrons by moisture. The log trace [fig. 11(c)] is low in the near-surface welded part of the Tiva Canyon. Neutron porosity values increase markedly with the end of dense welding at the base of the columnar subzone of the lower nonlithophysal zone of the Tiva Canyon Tuff. Neutron porosity values then decrease progressively through the lower vitric portion of the Tiva Canyon to the contact of the underlying bedded tuff (Tpbt4) 
at 92.3 feet $(28.1 \mathrm{~m})$. A small increase in neutron porosity is indicated within the bedded tuff unit. With the notable exception of a small increase within the slightly welded portion of the Yucca Mountain Tuff (centered at a depth of approximately $110 \mathrm{ft}(33 \mathrm{~m})$, neutron porosity values are relatively low down to the onset of welding located somewhat below the stratigraphic top of the Topopah Spring Tuff at 252.6 feet $(77.0 \mathrm{~m})$. The other bedded tuff units (Tpbt 3 and Tpbt2) within the upper Paintbrush nonwelded interval (PTn) exhibit little or no effect on neutron porosity values.

Within the upper vitric zone of the Topopah Spring Tuff, the neutron porosity values increase toward the upper contact of the caprock vitrophyre at 268.0 feet $(81.7 \mathrm{~m})$. Below the vitrophyre, neutron porosity values return to relatively low values. Neutron porosity values typically increase through the upper lithophysal zones and the character of the log response within lithophysal intervals is markedly more erratic, and the tool may be responding to low apparent moisture contents within the large lithophysal cavities. A marked interval of high neutron porosity values occurs at approximately the base of the lithophysal-bearing subzone of the middle nonlithophysal zone of the Topopah Spring Tuff. Neutron porosity values are somewhat low but relatively slowly varying in the lower vitrophyre subzone, and the log trace indicates rapidly increasing values through the partially welded and nonwelded vitric subzones between 1418.7 and 1464.1 feet (432.4-446.3 m).

\section{Dual-Induction Log Response}

The dual-induction log tool responds to the apparent resistivity of the rocks surrounding the bore hole. Both the induction log deep and medium traces are portrayed in figure 11(d). A third electrical tool, the spherical-focused $\log$, was also run in drill hole SD-9; however data from this tool are available only below approximately $1450 \mathrm{ft}$ (440 $\mathrm{m})$, and the trace is not included on the figure.

Electrical-type logging tools are somewhat problematic to interpret in the unsaturated zone, and the traces for this tool are included only for completeness. The high-resistivity spikes above 50 $\mathrm{ft}(15 \mathrm{~m})$ appear to be artifacts associated with steel surface casing. Resistivity values are generally low throughout the Paintbrush nonwelded (PTn) interval, and increase abruptly to off-scale readings (greater than $2000 \Omega-m$ ) at the top of the Topopah Spring Tuff. Resistivity values are off scale essentially throughout the upper nonlithophysal portion of the Topopah Spring. The prominent lithophysal zones of the Topopah Spring are not easily identified in the induction-log traces. The upper lithophysal zone exhibits resistitvities of slightly less than $500 \Omega-m$, whereas readings in the lower lithophysal zone are somewhat higher than $500 \Omega$-m. Resistivity values decrease in the lower part of the lower nonlithophysal zone, reaching a prominent minimum value just above the lower vitrophyre. Off-scale resistivity readings are associated with the Topopah lower vitrophyre subzone. Resistivity values decrease progressively through the moderately welded portion of the basal Topopah vitric zone, and remain low to the bottom of the logged interval.

\section{Caliper Log Response}

The upper part of drill hole USW SD-9 (below surface casing to $53.6 \mathrm{ft}(16.34 \mathrm{~m})$ was drilled using tools that produced an approximately 6-inch (15-cm) diameter drill hole. The caliper log trace [fig. 11(e)], which consists of two measurements at each depth in mutually perpendicular directions, indicates that the drill hole is severely washed out in the Paintbrush nonwelded interval above 268.6 $\mathrm{ft}(81.86 \mathrm{~m})$. Changes in the caliper log through this zone approximate changes in the degree of welding. Hole diameter increases progressively through the shardy-base portion of the partially welded and nonwelded basal Tiva Canyon Tuff, decreases through the partially welded portion of the Yucca Mountain Tuff, and then increases to a maximum of about 10.5 inches $(27 \mathrm{~cm})$ immediately above $200 \mathrm{ft}(61 \mathrm{~m})$ within the nonwelded ash flows of the Pah Canyon Tuff. Core recovery was essentially zero at this depth [fig. 4(a)]. Hole diameter then decreases progressively to the nominal hole size at the top of the caprock vitrophyre subzone of the Topopah Spring welded tuff.

Hole diameter within the welded portion of the Topopah Spring Tuff are generally in-gauge when averaged over thicker intervals. However, short, rather large washed-out intervals that may increase 
hole diameter by a third to more than 8 inches ( 20 $\mathrm{cm}$ ) are common throughout the welded interval. These enlarged intervals are thought to correspond to large lithophysal cavities intersected by the bore hole and to intervals of highly fractured rock that "ravel" into the hole with the mechanical agitation of the rotating drill string.

\section{Summary and Conclusions}

Drill hole USW SD-9 is one of several holes drilled under Site Characterization Plan Study 8.3.1.4.3.1, also known as the "Systematic Drilling Program," as part of the U.S. Department of Energy characterization program at the Yucca Mountain site. The SD-9 drill hole was located in the northern part of the potential repository area. The hole is immediately to the west of the Main Test Level drift of Exploratory Studies Facility. The location is just south of the curve connecting the North Ramp decline with the north-south main test level drift. The drill hole collar is located in the bottom of Wren Wash, which has eroded nearly to the base of the Tiva Canyon Tuff. Core from drill hole USW SD-9 recovered essentially complete sections of ash-flow tuffs belonging to the Yucca Mountain, Pah Canyon, and Topopah Spring Tuffs of the Miocene Paintbrush Group, as well as a complete section of the Calico Hills Formation and all but the lowermost part of the Prow Pass Tuff section of the Crater Flat Group.

Wren Wash and the SD-9 drill hole are located relatively close to the inferred source calderas of the Paintbrush Group ash-flow and related tuffs, compared with drill holes located farther to the south within the potential repository block. The Yucca Mountain Tuff is approximately 45-ft (13.7$\mathrm{m})$ thick, and the interior portion of this ash flow is partially welded. The Yucca Mountain Tuff thins to extinction southward. The Pah Canyon Tuff is 69.4 $\mathrm{ft}(21.15 \mathrm{~m})$ thick in this drill hole and is completely nonwelded. The Topopah Spring Tuff consists of $1211.5 \mathrm{ft}(369.25 \mathrm{~m})$ of generally densely welded material; this is one of the thickest known sections of welded Topopah Spring Tuff at or near Yucca Mountain. Lithophysae are well developed locally within the part of the Topopah Spring, and large lithophysal cavities up to several feet (many tenths of a meter) in diameter are present through- out roughly the lower two-thirds of the unit. This somewhat anomalous occurrence of very large lithophysal cavities, which is in addition to the better known presence of zones containing smaller, inch-scale (cm-scale) lithophysae within the Topopah Spring, may be related to the greater thickness of the unit at this geographic location. The Calico Hills Formation underlies the Paintbrush Group tuffs, and this unit consists of $341 \mathrm{ft}$ $(103.87 \mathrm{~m})$ of nonwelded and mostly zeolitized tuffaceous materials. Rocks totaling $402.4 \mathrm{ft}$ $(122.65 \mathrm{~m})$ in thickness and belonging to the ashflow sequences of the Prow Pass Tuff underlie the Calico Hills Formation. The drill hole was stopped short of the base of the lowermost known ash-flow unit of the Prow Pass Tuff, and the true thickness of this unit is not known.

Quantitative and semiquantitative data are included in this report for core recovery, rock-quality designation (RQD), lithophysal cavity abundance, and fracturing. These data are variable spatially, both within and among the major formational-level stratigraphic units. Core recovery and RQD values are typically somewhat inversely correlated with the degree of welding; nonwelded intervals exhibit higher recoveries and more intact (higher) RQD values. An exception is a completely unconsolidated nonwelded interval near the base of the Pah Canyon Tuff. RQD is distinctly lower in the main lithophysal zones. Rocks of the nonwelded and generally zeolitized intervals belonging to the Calico Hills Formation and Prow Pass Tuff yielded virtually complete core recovery and the consistently highest RQD indices of the entire drill hole. Quantitative information regarding lithophysal cavity abundances is complicated by the existence of cavities much larger than the core diameter; drilling through intervals of these large cavities produced large zones of "lost" core and rubble.

Quantitative data for the framework material properties of porosity, bulk density, and saturated hydraulic conductivity are tabulated in this report. Graphical representations of variations in these laboratory hydrologic properties reflect the degree of welding and the presence of zeolitization. Many of the contacts between primary, genetic geologic contacts are not expressed in the material-property 
profiles. Approximate in-situ saturation data of samples preserved immediately upon recovery from the hole are included in the data tabulation. These numeric values of the framework material properties can be used to develop a "material-property stratigraphy" that appears to correspond in a first-order manner to the older thermal/mechanical stratigraphy used for some Yucca Mountain Project activities.

Geophysical logs have been obtained for the upper approximately $1500 \mathrm{ft}(450 \mathrm{~m})$ of the USW SD-9 drill hole (to near the base of the Paintbrush Group). The lower part of the hole has not been logged. The suite of geophysical log traces included in the report include density, gamma-ray, epithermal-neutron porosity, electrical resistivity, and caliper profiles down to the base of the Topopah Spring Tuff. The bulk-density log provides the most lithologic information, and several of the lithologic subdivisions identified in the SD-9 drill hole can be tied to distinctive changes in the density trace. Discrimination of welded from nonwelded rock types and lithophysal from nonlithophysal zones is immediately apparent in the density log. This independent line of evidence also confirms the fact that the broader, genetic lithostratigraphic unit boundaries do not correspond in detail to material property units as identified either through the use of geophysical logs or laboratory measurements on core samples.

\section{References}

ASTM (American Society for Testing and Materials), 1990, Standard test methods for absorption and bulk-specific gravity of dimension stone: 1995 Annual Book of ASTM Standards, C97-90(1994), v. 04.07.

Buesch, D.C., Spengler, R.W., Moyer, T.C., and Geslin, J.K., 1996, Proposed stratigraphic nomenclature and macroscopic identification of lithostratigraphic units of the Paintbrush Group exposed at Yucca Mountain, Nevada: U.S. Geological Survey OpenFile Report 94-469, $47 \mathrm{p}$.

Bush, D.C., and Jenkins, R.E., 1970, Proper hydration of clays for rock property determinations: Journal of Petroleum Technology, v. 22, p. 800-804.
Byers, F.M., Jr., Carr, W.J., Christiansen, R.L., Lipman, P.W., Orkild, P.P., Quinlivan, W.D., and Sargent, K.A., 1976, Geologic map of the Timber Mountain caldera area, Nye County, Nevada: U.S. Geological Survey Miscellaneous Investigations Series Map I891 , scale 1:48000.

Byers, F.M., Jr., Carr, W.J., and Orkild, P.P., 1989, Volcanic centers of southwestern Nevada: Evolution of understanding, 1960-1988: Journal of Geophysical Research, v. 94, p. 5908-5924.

Carr, M.D., Waddell, S. J., Vick, G. S., Stock, J.M., Monsen, S.A., Harris, A.G., Cork, B.W., and Byers, F.M., Jr., 1986, Geology of drill hole UE25p\#1: A test hole into pre-Tertiary rocks near Yucca Mountain, southern Nevada: U.S. Geological Survey Open-File Report 86-175, $87 \mathrm{p}$.

Carr, W.J., 1984, Regional structural setting of Yucca Mountain, southwestern Nevada, and late Cenozoic rates of tectonic activity in part of the southwestern Great Basin, Nevada and California: U.S. Geological Survey Open-File Report 84-854, 109 p.

Carr, W.J., 1988, Volcano-tectonic setting of Yucca Mountain and Crater Flat, southwestern Nevada, in Carr, M.D., and Yount, J.C., Geologic and hydrologic investigations of a potential nuclear waste disposal site at Yucca Mountain, southern Nevada: U.S. Geological Survey Bulletin 1790, p. 35-49.

Carr, W.J., Byers, F.M., Jr., and Orkild, P.P., 1986, Stratigraphic and volcano-tectonic relations of the Crater Flat tuff and some older volcanic units: U.S. Geologic Survey Professional Paper 1323, 28 p.

Christiansen, R.L., and Lipman, P.W., 1965, Geologic map of the Topopah Spring NW quadrangle, Nye County, Nevada: U.S. Geologic Survey Geologic Quadrangle Map GQ-444, scale, 1:24000, 1 sheet.

Christiansen, R.L., Lipman, P.W., Carr, W.J., Byers, F.M., Jr., Orkild, P.P., and Sargent, K.A., 1977, The Timber Mountain-Oasis Valley caldera complex of southern Nevada: Geological Society of America Bulletin, v. 88, p. 943-959.

Deere, D.U., 1963, Technical description of rock cores for engineering purposes: Felsmechanik und Ingenieurgeologie (Rock Mechanics and Engineering Geology), v. 1, p. 16-22.

Deere, D.U., and Deere, D.W., 1989, Rock quality designation (RQD) after twenty years: U.S. Army 
Corps of Engineers, Waterways Experiment Station Contract Report GL-89-1, 100 p.

DOE (U.S. Department of Energy), 1988, Site characterization plan, Yucca Mountain site, Nevada Research and Development Area, Nevada: Report DOE/RW-0198, U.S. Department of Energy, Office of Civilian Radioactive Waste Management, Washington, D.C.

Geological Society of America, 1991, Rock-color chart: Geological Society of America, Boulder, Colo.

Istok, J.D., Rautman, C.A., Flint, L.E., and Flint, A.L., 1994, Spatial variability of hydrologic properties of a volcanic tuff: Ground Water, v. 32, p. 751-760.

Lappin, A.R., VanBuskirk, R.G., Enniss, D.O., Butters, S.W., Prater, F.M., Muller, C.B., and Bergosh, J.L., 1982, Thermal conductivity, bulk properties, and thermal stratigraphy of silicic tuffs from the upper portion of hole USW-G1, Yucca Mountain, Nye County, Nevada: Sandia Report SAND81-1873, Sandia National Laboratories, Albuquerque, $\mathbf{N}$. Mex., 48 p.

Lipman, P.W., and Christiansen, R.L., 1964, Zonal features of an ash-flow sheet in the Piapi Canyon Formation, southern Nevada, in Geological Survey Research 1964: U.S. Geological Survey Professional Paper 501-B, p. B74-B78.

Lipman, P.W., Christiansen, R.L., and O'Connor, J.T., 1966, A compositionally zoned ash-flow sheet in southern Nevada: U.S. Geological Survey Professional Paper 524-F, p. F1-F47.

Maldonado, F., and Koether, S.L., 1983, Stratigraphy, structure and some petrographic features of Tertiary volcanic rocks at the USW G-2 drill hole, Yucca Mountain, Nye County, Nevada: U.S. Geological Survey Open-File Report 83-732, 83 p.

Moyer, T.C., and Geslin, J.K., 1995, Lithostratigraphy of the Calico Hills Formation and Prow Pass Tuff (Crater Flat Group) at Yucca Mountain, Nevada: U.S. Geological Survey Open-File Report 94-460, $59 \mathrm{p}$.

Nimick, F.B., and Schwartz, B.M., 1987, Bulk, thermal, and mechanical properties of the Topopah Spring Member of the Paintbrush Tuff, Yucca Mountain, Nevada: Sandia Report SAND85-0762, Sandia National Laboratories, Albuquerque, N. Mex., $180 \mathrm{p}$.
Noble, D.C., Vogel, T.A., Weiss, S.I., Erwin, J.W., McKee, E.H., and Younker, L.W., 1968, Stratigraphic relations and source areas of ash-flow sheets of the Black Mountain and Stonewall volcanic centers, Nevada: Journal of Geophysical Research, v. 89, p. 8593-8602.

Ortiz, T.S., Williams, R.L., Nimick, F.B., Whittet, B.C. and South, D.L., 1985, A three-dimensional model of reference thermal/mechanical and hydrological stratigraphy at Yucca Mountain, southern Nevada: Sandia Report SAND84-1076, Sandia National Laboratories, Albuquerque, N. Mex., 76 p.

Rautman, C.A., 1993, Study plan for the systematic acquisition of site-specific subsurface information, site characterization plan study 8.3.1.4.3.1, YMPSNL-SP-8.3.1.4.3.1, R1, U.S. Department of Energy, Office of Civilian Radioactive Waste Management, Washington, D.C., $61 \mathrm{p}$.

Ross, C.S., and Smith, R.L., 1961, Ash-flow tuffs: their origin, geological relations, and identification: U.S. Geological Survey Professional Paper 366, 81 p.

Sawyer, D.A., Fleck, R.J., Lanphere, M.A., Warren, R.G., Broxton, D.E., and Hudson, M.R., 1994, Episodic caldera volcanism in the Miocene southwestem Nevada volcanic field: Revised stratigraphic framework, ${ }^{40} \mathrm{Ar} /{ }^{39} \mathrm{Ar}$ geochronology, and implications for magmatism and extension: Geological Society of America Bulletin, v. 106, p. 1304-1318.

Scott, R.B., and Bonk, J., 1984, Preliminary geologic map of Yucca Mountain, Nye County, Nevada, with geologic sections, Nye County, Nevada: U.S. Geological Survey Open-File Report 84-494, 10 p., 3 sheets.

Scott, R.B., and Castellanos, M., 1984, Stratigraphic and structural relations of volcanic rocks in drill holes USW GU-3 and USW G-3, Yucca Mountain, Nye County, Nevada: U.S. Geological Survey Open-File Report 84-491, 127 p.

Scott, R.B., Spengler, R.W., Diehl, S., Lappin, A.R., and Chornack, M.P., 1983, Geologic character of tuffs in the unsaturated zone at Yucca Mountain, southern Nevada, in J. Mercer, P.S.C. Rao, and I.W. Marine, eds., Role of the unsaturated zone in radioactive and hazardous waste disposal, Ann Arbor Science, Ann Arbor, Mich., p. 289-335.

Soeder, D.J., Flint, L.E., and Flint, A.L., 1991, Effects of sample handling and measurement methodology on the determination of porosity in volcanic rock 
samples (abs.): Agronomy Abstracts, 1991 Annual Meeting, p. 232.

Spengler, R.W., Byers, F.M., Jr., and Warner, J.B., 1981, Stratigraphy and structure of volcanic rocks in drill hole USW-G1, Yucca Mountain, Nye County, Nevada: U.S. Geological Survey Open-File Report 81-1349, $51 \mathrm{p}$.

USGS (U.S. Geological Survey) 1991a, Characterization of the Yucca Mountain unsaturated-zone percolation, site characterization plan study 8.3.1.2.2.3, YMP-USGS-SP 8.3.1.2.2.3, RO, U.S. Department of Energy, Office of Civilian Radioactive Waste Management, Washington, D.C.
USGS, 1991b, Studies to provide soil and rock properties of potential locations of surface and subsurface access facilities, site characterization plan study 8.3.1.14.2, YMP-USGS/USBR-SP 8.3.1.14.2, RO, U.S. Department of Energy, Office of Civilian Radioactive Waste Management, Washington, D.C.

Whitfield, M.S., Jr., Thordarson, W., and Eshom, E.P., 1984, Geohydrologic and drill-hole data for test well USW H-4, Yucca Mountain, Nye County, Nevada: U.S. Geologic Survey Open-File Report $84-449,69 \mathrm{p}$. 
This page intentionally left blank. 


\section{Appendix A: Detailed Lithologic Descriptions}




\section{Lithologic Unit Descriptions}

The following are unit-by-unit descriptions of the USW SD-9 core. The SD-9 Borehole was hammer-drilled to $53.6 \mathrm{ft}(16.34 \mathrm{~m})$; drill-pad-fill material and alluvial overburden were neither cored nor described. The descriptions that follow are based on the detailed geologic log sheets presented in Appendix $B$, and reference to the $\log$ forms may be helpful when reading these lithologic unit descriptions. Although these descriptions emphasize the new stratigraphic nomenclature proposed by Buesch and others (1996), the unit descriptions are cross-referenced where feasible to the older zonation of the Paintbrush Group tuffs published by Scott and Bonk in 1984. These older names and some of their historical modifications are well entrenched on the Yucca Mountain Project.

\section{Tiva Canyon Tuff (Tpe)}

\section{Crystal-poor lower nonlithophysal zone (Tpcpln) 53.6-55.7 ft (16.34-16.98 m)}

\section{Columnar subzone (Tpcp/nc) 53.6-55.7 ft $(16.34-16.98 \mathrm{~m})$}

The lowermost portion of the columnar subzone (columnar zone of Scott and Bonk) is characterized by a light tan-gray, densely welded, devitrified matrix punctuated by dark, vitric, flattened, rectangular pumice clasts with feathery ends. More sparse, larger pumice clasts have been argillically altered to pink clay. The rock is composed of 4-6 percent dark pumice fragments, 1-2 percent dark vitric lithics, and 3-4 percent phenocrysts of feldspar with minor biotite. Joints are dominantly smooth and high-angle (nearly parallel to the core axis), and are typically coated by vaporphase minerals. The contact at $55.7 \mathrm{ft}(16.98 \mathrm{~m})$ between the columnar subzone and the underlying lower vitric zone is faulted, with $0.1 \mathrm{ft}(30.5 \mathrm{~mm})$ of sandy-clay gouge that appears related genetically to the vitric zone. The columnar subzone is severely fractured because of its proximity to this low-angle fault (nearly perpendicular to the core axis in a vertical drill hole), and then healed (refilled) with milled fragments of the vitric zone in the fracture voids.

\section{Crystal-poor vitric zone (Tpcpv) $55.7-92.3 \mathrm{ft}$} (16.98-28.14 m)

\section{Moderately welded subzone (Tpcpv2) 55.7-65.0 tt} (16.98-19.92 m)

This partially welded section of the lower vitric zone (described as the "shardy base" of the columnar zone of Scott and Bonk; Istok and others, 1994) is composed of a matrix of moderately deformed orange-brown bubble-wall shards that enclose light pink-gray, weakly altered pumice clasts, 1 percent small brown angular lithic fragments, and 2-3 percent phenocrysts. Some pumice fragments are as large as 1.6 inches $(40 \mathrm{~mm})$ in diameter; some are altered to orange clay and about one-fourth of the clasts are black and vitric. Phenocrysts are dominantly feldspar, with traces of biotite. Approximately 3-5 percent of the shards that make up the matrix are obsidian.

\section{Nonwelded subzone (Tpcpv1) 65.0-92.3 ft} $(19.82-28.14 \mathrm{~m})$

The nonwelded subzone (also aggregated as part of the shardy base interval by Istok and others, 1994) occurs from a depth of 65.0 to $79.0 \mathrm{ft}(19.82$ to $24.09 \mathrm{~m}$ ). The lower nonwelded subzone contains $7-10$ percent pale orange-brown, weakly altered pumice fragments up to 1 inch $(28 \mathrm{~mm})$ in diameter, 1-2 percent small brown angular lithics, 3-4 percent phenocrysts of feldspar, and traces of biotite in a vitric, nonwelded matrix composed mostly of partially argillized, orange-brown bubble-wall shards. Approximately $20-25$ percent of the shards constituting the matrix are black and vitric. Fractures in this interval are generally smooth and are commonly coated with a black mineral. At a depth of $88.7 \mathrm{ft}(27.04 \mathrm{~m})$, the pumice content increases with proximity to the base of the Tiva Canyon section. The lowermost subunit is a 1.2 inch $(30.5 \mathrm{~mm})$-thick pumice fall underlain by a sharp basal contact.

\section{Pre-Tiva Canyon Tuff bedded tuff (Tpbt4) 92.3-95.9 ft (28.14-29.24 m)}

The upper contact of the pre-Tiva Canyon Tuff bedded tuff is a weakly developed paleosurface. The unit has a sandy, clast-supported texture with 5-7 percent small, white, angular pumice fragments, 4-5 percent feldspar, and traces of biotite phenocrysts. This unit grades downward into a 
medium-grained pumice-fall deposit that becomes coarser downward. The fallout deposit is composed of mixed pumice types; $10-15$ percent of the clasts are a black obsidian variety.

\section{Yucca Mountain Tuff (Tpy) 95.9-140.9 ft (29.24-42.95 m)}

The Yucca Mountain Tuff is a vitric, weakly vapor-phase-altered, nonwelded ash-flow tuff containing 5-10 percent small, dense-textured, vitric pumice fragments, 1-2 percent phenocrysts of feldspar and lesser biotite, and 1 percent small angular lithics of quartz latite. The matrix is composed of a pale red-brown weakly altered mass of indistinguishable material that contains 5 percent black vitric shards, which increase in abundance downward to 10-12 percent. The tuff becomes slightly welded from 121.7 to $133.7 \mathrm{ft}$ (37.10 to $40.76 \mathrm{~m}$ ), and contains $10-15$ percent black shards in a gray vitric matrix with hazy, recrystallized (altered?) spots. Pale-colored, vitric pumice clasts grade downward into black vitric, "soft lithics" in this zone. The lower contact is depositional.

A second faulted interval is present at a depth of $122.1 \mathrm{ft}(37.21 \mathrm{~m})$. This $0.15-\mathrm{ft}(0.046-\mathrm{m})$ thick gouge zone of soft clayey material is essentially flat-lying, as was the fault encountered at $55.7 \mathrm{ft}$ $(16.98 \mathrm{~m})$ marking the division between the Tiva Canyon columnar subzone and the underlying shardy-base interval.

\section{Pre-Yucca Mountain Tuff bedded tuff (Tpbt3) $140.9-157.7 \mathrm{ft}(42.96-48.08 \mathrm{~m})$}

The pre-Yucca Mountain Tuff bedded tuff is a clast-supported, highly pumiceous unit with a vitric matrix. The bedded tuff consists of 25-35 percent small, subangular pumice fragments, 1-2 percent phenocrysts of feldspar and minor biotite, and 1 percent small dark lithics in an altered and reworked vitric matrix containing 2-3 percent black shards. Three sets of well-sorted, oscillatory 2- to 5-cm-thick, lithic-rich pumice-fall beds occur between depths of 143.2 and $143.5 \mathrm{ft}$ (43.66 to $43.75 \mathrm{~m})$. From 143.5 to $154.2 \mathrm{ft}(47.01 \mathrm{~m})$, the rock exhibits a reworked bedded texture with a pumice content of 15-20 percent; pumice clasts are slightly larger than near the top of the unit. A wellsorted pumiceous ash fall grades downward into a coarse-grained pumice fall from $154.2 \mathrm{ft}$ to $156.7 \mathrm{ft}$ $(47.77 \mathrm{~m})$. The final interval from $156.7 \mathrm{ft}$ to the bottom of the unit at $157.7 \mathrm{ft}(48.08 \mathrm{~m})$ is a sandy, clast-supported bedded tuff composed of material similar in composition to, and presumably derived from, the underlying Pah Canyon Tuff.

\section{Pah Canyon Tuff (Tpp) 157.7-227.1 ft (48.08-69.24 m)}

The Pah Canyon Tuff is an ash-flow deposit containing 25-30 percent pale-colored, subangular pumice clasts (0.12-1.77 inch; 3-45 mm) set in a nonwelded, vitric, slightly altered light-brick-red matrix. The pumice clasts are bimodal, with approximately equal portions of a light gray, densetextured, vitric variety and a finely-laminated vesicular type, all of which vary in size from 0.47 to 1.77 inch $(12-45 \mathrm{~mm})$. Pumice clasts become green and zeolitized below $164.0 \mathrm{ft}(50 \mathrm{~m})$ depth. The Pah Canyon Tuff also contains 1 percent darkcolored, 0.31-0.39-inch (8-10-mm) lithic fragments and 3-5 percent phenocrysts of feldspar with traces of biotite. A characteristic, pumiceous, basal "white zone" is present from 223.9 to $227.1 \mathrm{ft}$ (68.26 to $69.24 \mathrm{~m}$ ).

\section{Pre-Pah Canyon Tuff bedded tuff (Tpbt2) 227.1-252.6 ft (69.24-77.01 m)}

The pre-Pah Canyon Tuff bedded tuff is nonwelded, vitric, sandy textured and probably reworked. The unit grades downward to a coarsegrained, pumice fall at $230.8 \mathrm{ft}(70.37 \mathrm{~m})$. The bedded tuff is composed of 20-25 percent small, lightgray, laminated and red-gray, altered pumice clasts, 2-4 percent dark vitric lithic clasts, 3-5 percent feldspar phenocrysts and 2 percent biotite flakes in an altered matrix with 4-5 percent black shard content. The coarse-grained fallout deposit from 230.8 to $252.6 \mathrm{ft}(77.01 \mathrm{~m})$ contains $85-90$ percent coarse, white, vitric pumice clasts up to 0.79 inch $(20 \mathrm{~mm})$ in diameter and a mixture of lithics that constitute 5-10 percent of the rock. A weakly developed paleosol surface with hematite staining is visible at $245.9 \mathrm{ft}(74.97 \mathrm{~m})$ in the pre-sampling core videos. 
Topopah Spring Tuff (Tpt)

\section{Crystal-rich vitric zone 252.6-272.1 ft (77.01-82.96 m)}

Nonwelded subzone (Tptrv3) 252.6-266.1 ft (77.01-81.13 m)

A 1.18 inch $(30 \mathrm{~mm})$, pink-clay and small pumice-clast zone found at $255.5 \mathrm{ft}(77.90 \mathrm{~m})$ has been identified by the Buesch and others (1996) as the upper part of a presumed paleosol unit. However, the ash-flow material both above and below this pink-clay marker are virtually identical in composition and texture. Thus, the upper contact of the Topopah Spring Tuff-and of the nonwelded vitric subzone-is placed at $252.6 \mathrm{ft}(77.01 \mathrm{~m})$, where the rock type changes from the coarsegrained pumice fall, assigned to the pre-Pah Canyon budded tuff, to nonwelded ash-flow tuff similar to some dozen or so feet (several meters) of underlying, nonwelded material.

The upper, vitric, nonwelded subzone (part of the caprock zone of Scott and Bonk) is pumiceous, normally containing 15-20 percent pumice clasts. The pumice content within this upper part of the Topopah Spring tuff appears to increase progressively from 15 or 20 percent to about $80-90$ percent between $261.1 \mathrm{ft}(79.60 \mathrm{~m})$, and the most prominent change in rock type at the top of the vitrophyre subzone at $268.6 \mathrm{ft}(81.89 \mathrm{~m})$. The entire upper portion of Topopah Spring Tuff is crystal rich, containing up to 20 percent phenocrysts of feldspar and biotite. However, the uppermost portion of the nonwelded subzone has a noticeably reduced phenocryst content (only 3-5 percent). Small, angular, quartz latite lithics (2-3 percent) are easily identified by their contrasting hardness relative to the nonwelded tuff.

\section{Moderately welded subzone (Tptrv2) 266.1-268.6 ft (81.13-81.89 m)}

Increased welding creates what is also sometimes referred to as a "sintered" interval within the pumiceous zone just above the vitrophyre subzone. The upper contact is placed at the uppermost limit of flattening affecting large gray pumice clasts that compose 80-90 percent of the pumiceous interval at the bottom of the upper vitric nonwelded subzone. Note that this "contact" is gradational. The rock is clast-supported, and consists of approxi- mately 10 percent devitrified and vitric lithic clasts and 3-5 percent feldspar and oxybiotite phenocrysts in a vitric matrix. Elsewhere at Yucca Mountain, the moderately welded interval is indistinguishable, and the rock type changes from virtually nonwelded to vitrophyre over an interval of inches.

Densely welded (vitrophyre) subzone (Tptrv1) 268.6-272.1 ft (81.89-82.96 m)

The densely welded or vitrophyre subzone (also known as the "caprock vitrophyre" after the description of Scott and Bonk, 1984) is composed of dark-colored, densely fused, crystal-rich glass. A distinctive red vitrophyre containing black glass fiamme from 268.6 to $271.6 \mathrm{ft}(81.89$ to $82.80 \mathrm{~m})$ overlies an equally distinctive black vitrophyre from $271.6 \mathrm{ft}$ to $272.1 \mathrm{ft}(82.96 \mathrm{~m})$. Phenocrysts of feldspar make up 15-20 percent of the rock with trace quantities of oxybiotite and rare pyroxene. A large, porphyritic pumice clast is present at $268.7 \mathrm{ft}$ $(81.92 \mathrm{~m})$. Thin, pale blue, weakly opaline, vapor phase silica coatings are present preferentially on open, dominantly subhorizontal, joints.

Laboratory material property data, discussed earlier in this report (See "Framework Hydrologic Properties" on page 23.), indicates that the greatest change in rock properties occurs at the very sharp upper contact of the underlying vitrophyre subzone.

Crystal-rich nonlithophysal zone (Tptrnl) 281.0$439.2 \mathrm{ft}(85.67-133.90 \mathrm{~m})$

The upper contact of the upper, crystal-rich nonlithophysal zone (rounded zone of Scott and Bonk) is gradational, and this unit is distinguished from the caprock vitrophyre only by the presence of incipient devitrification. The unit is composed of 15-17 percent phenocrysts, $10-30$ percent cognate pumice clasts, $10-15$ percent exotic (hard) quartz-latitic clasts, and 2-3 percent rhyolitic softlithic fragments set in densely welded, devitrified matrix. Phenocrysts include sanidine, minor plagioclase and biotite, with lesser pyroxene and hornblende, and accessory magnetite. Predominantly light gray to light pink-gray, vapor-phase altered pumice fragments increase abruptly from 5-10 percent to around 30 percent approximately $50 \mathrm{ft}(15.24 \mathrm{~m})$ below the top of the unit at about 
$230 \mathrm{ft}(70 \mathrm{~m})$. Fine-grained, aphyric and porphyritic volcanic lithic fragments are present throughout the unit. Lithophysae are only weakly developed and these are widely spaced within the nonlithophysal zone, changing in form from weakly opened vugs near the upper contact of the unit to small, flattened lithophysae in a lower zone from 318.0 to $322.7 \mathrm{ft}$ (96.95 to $98.38 \mathrm{~m})$ depth. The uppermost vapor-phase mineral coating of a lithophysal cavity occurs at a depth of $329.0 \mathrm{ft}$ $(100.30 \mathrm{~m})$. Vapor-phase alteration of the matrix is pronounced, although relict shard textures are preserved locally.

\section{Crystal-rich lithophysal zone (Tptrl) and Crystal-poor upper lithophysal zone (Tptpul) 439.2-728.8 ft (133.90-222.20 m)}

The abundance of lithophysae increases abruptly to more than 10 percent of the rock at $439.2 \mathrm{ft}(133.90 \mathrm{~m})$ defining the upper lithophysal interval of the Topopah Spring Tuff. Scott and Bonk (1984) subdivided this interval into a host of laterally equivalent and vertically variable units based principally upon color. The intensity of vapor-phase alteration associated with the lithophysae also increases with depth, and the densely welded and devitrified matrix of the core becomes pale red-purple. Lithophysae continues to increase in abundance downward. At $439.2 \mathrm{ft}$, the core averages about 25 percent lithophysae that are approximately $0.39-1.18$ inch $(10-30 \mathrm{~mm})$ in diameter and exhibit pink-gray alteration halos. Rock constituents in the crystal--rich portion of this interval include 10-12 percent feldspar phenocrysts, 0.5 percent oxybiotite crystals, and less than 1 percent small, hard lithic fragments (red-brown quartz latite). Nonlithophysal pumice clasts constitute approximately 25 percent of the rock at the top and bottom of the upper lithophysal zone, but diminish inward and are absent in the center of this interval. Pumice clasts up to $0.98-1.97$ inches $(25-50 \mathrm{~mm}$ ) change from light gray or white at the top of the unit, to pale-brown at the bottom. Pumice clasts are up to 2.36 inches $(60 \mathrm{~mm})$ in diameter in the lower part of the unit.

Compositional transition interval $-\mathbf{4 5 4 . 7}$ to $468.6 \mathrm{ft}$ (138.63 to $142.87 \mathrm{~m})$ : The core changes gradually in composition downward through this transition interval from brown, crystal-rich quartz latite containing flattened and deformed cognate lithics of more-grey-colored, crystal-poor rhyolite to medium-gray crystal-poor rhyolite containing flattened and deformed clasts of brownish crystalrich quartz latite.

Crystal transition interval -448.2 to $485.2 \mathrm{ft}$ (136.61 to $147.88 \mathrm{~m}$ ): The phenocryst content of the matrix (excluding the deformed, cognate lithic clasts) changes from 10-20 percent at $448.2 \mathrm{ft}$ $(136.61 \mathrm{~m})$ to only $3-5$ percent at $485.2 \mathrm{ft}(147.92$ $\mathrm{m})$. This change in phenocryst content corresponds to a change in rock type from crystal-rich quartz latite (Tptr) to crystal-poor rhyolite (Tptp). This $37-\mathrm{ft}(11-\mathrm{m})$ thick interval contains the gradational contact between the crystal-rich and crystal-poor (informal) members of the Topopah Spring Tuff (table 2). Elsewhere at Yucca Mountain, the crystal transition between quartz latite and rhyolite occurs at different positions with respect to zonal structure produced by alteration phenomena, such as lithophysae development. In such locations, the crystalrich lithophysal zone (Tptrl) may appear to be absent. In fact, lithophysal-style alteration is simply restricted to intervals below the crystal transition interval; zonal boundaries thus cross-cut the member boundaries.

Below $456.0 \mathrm{ft}(139.02 \mathrm{~m})$, lithophysae increase in abundance with the development of close-spaced, larger, ragged lithophysae that are weakly coated by vapor-phase minerals. Extensive broken or unrecovered intervals below $460.0 \mathrm{ft}$ $(140.24 \mathrm{~m})$ are most likely caused by presence of lithophysal cavities that are several times larger than the drill-pipe diameter. The existence of large lithophysal cavities was confirmed by the downhole video survey. The intensity of lithophysal development and vapor-phase alteration decreases downward below about $600 \mathrm{ft}(183 \mathrm{~m})$. The lithophysae gradually become thin, flattened, vuggy cavities with thin alteration halos at approximately $700 \mathrm{ft}(213.41 \mathrm{~m})$ depth.

\section{Crystal-poor middle nonlithophysal zone (Tptpmn) 728.8-845.8 ft (222.2-257.87 m)}

The contact of the crystal-poor upper lithophysal zone with the crystal-poor middle nonlithophysal zone (nonlithophysal and "brick" zones of Scott and Bonk) is notably gradational, and litho- 
physae are present through much of the so-called nonlithophysal interval. The contact is identified where the intensity of lithophysal-style alteration decreases and is observed to affect less than 10 percent of the rock mass. A 24-ft (7.4-m) lithophysalbearing subzone ( 24 percent of the total interval) occurs within the middle nonlithophysal zone, extending from 788.1 to $812.5 \mathrm{ft}$ (240.27 to 274.71 $\mathrm{m})$.

The rock is composed of 1-2 percent feldspar phenocrysts, 0-10 percent flattened, vuggy lithophysae, and minor quantities of small, light-gray or red-brown lithic fragments; these lithic clasts are more prevalent lower in the zone. Sanidine is the most abundant phenocryst, with minor amounts of plagioclase and biotite; magnetite is present as an accessory mineral. The rock matrix is densely welded and devitrified, with a more compact, lessgrainy texture than that present in overlying units. Two types of alteration can be distinguished: (1) a strong, pervasive, blue alteration with 17 percent fuzzy, white, 0.6 inch $(15 \mathrm{~mm})$ long vapor-phase streaks surrounding pumice clasts, lithophysae and islands of unaltered matrix; and (2) a more speckled or spotted type of alteration consisting of 1 percent white streaks and $0.28-0.31$ inch $(7-8 \mathrm{~mm})$ spots in unaltered orange-pink devitrified matrix. Hairline vapor-phase silica veinlets make up as much as 2 percent of the rock volume. Welding foliation is not common except where the core has been distorted by the lithophysal-bearing subzone. Jointing is mostly vertical and joint surfaces are typically smooth.

\section{Crystal-poor lower lithophysal zone (Tptpll) 845.8-1187.0 ft (257.87-361.89 m)}

The top of the crystal-poor lower lithophysal zone of the Topopah Spring Tuff in SD-9 (simply called the lower lithophysal zone, with several color-based modifiers, by Scott and Bonk) is well defined by the presence of somewhat diffuse, granular-appearing vapor-phase alteration of the matrix, and by vapor-phase altered spots and small, pinched, oval-shaped lithophysae that are generally less than 0.8 inches $(20 \mathrm{~mm})$ in size; the spacing of these lithophysae is wider than that found in the upper lithophysal zone. Much of the core throughout this interval is highly fractured or has been lost. Fracturing and associated core loss are attributed to the presence of lithophysae several times larger than the drill-string diameter. These large lithophysae, which also occur at other depths where smaller lithophysae are not present, are well expressed in the down-hole video survey. The abundance of lithophysae decreases gradually downward.

The rock is densely welded, devitrified, and composed of 10-12 percent white vapor-phase replacement of flattened, wispy, former pumice sites within 1-inch $(25-\mathrm{mm})$ diameter pale, pinkbrown alteration spots, 1-2 percent sanidine phenocrysts, 0.5 percent biotite, trace plagioclase, and accessory magnetite. Small, pale-gray pumice clasts, and pale-gray rhyolitic lithic fragments are concentrated in lithic-rich zones from 1031.0 $1075.4 \mathrm{ft}(314.33-329.87 \mathrm{~m})$ and $1107.7-1118.5 \mathrm{ft}$ (337.71-341.01 m). Welding foliation is weakly to moderately developed in the lower two-thirds of the unit. The core is broken throughout the lithophysal zone and the fractures are irregular with rough surfaces.

\section{Crystal-poor lower nonlithophysal zone (Tptpln) 1187.0-1365.0 ft (361.89-416.16 m)}

The upper contact of the crystal-poor lower nonlithophysal zone (mottled zone of Scott and Bonk) is identified by a change of rock type to a dense, less grainy (less altered) matrix and a decrease in the abundance of lithophysae. As mesoscale lithophysae continue to decrease in abundance downward, the number of identifiable pumice clasts, which range in size from 0.08 to 0.59 inch ( 2 to $15 \mathrm{~mm}$ ), increases to about 7 percent. The rock is composed of $2-4$ percent phenocrysts, $2-15$ percent pumice clasts, and 2-3 percent small, white rhyolite lithics. Sanidine is the dominant phenocryst with traces of plagioclase and biotite, and accessory magnetite. The number of rhyolitic lithic fragments increases to 4-5 percent of the rock at about $1253.0 \mathrm{ft}(382.01 \mathrm{~m})$.

In general, the color of the matrix darkens with depth; the upper half of the unit is roughly equally divided between pale-red-purple and light-orangegray; the third quarter of the unit is a medium-redpurple or red-brown, and the lowest quarter is dark-brown-gray. This variation in matrix color, particularly in the upper portion of the intervals - produces a mottled appearance, leading to the older 
descriptive name, "mottled." About 20 percent of the matrix is unaltered other than for early devitrification. In addition to producing light-pink alteration halos and wisps and pervasive blue alteration, vapor-phase alteration has healed microfractures throughout the rock with thin (millimeter-scale) selvages and created hairline coatings of silica and accessory minerals. For the most part, welding foliation is weakly developed. Nearly vertical and subhorizontal fractures predominate throughout the unit. High-angle, planar, smooth fractures are more prevalent in the lower part of the lower nonlithophysal zone.

\section{Crystal-poor vitric zone}

Densely welded (vitrophyre) subzone (Tptpv3) 1365.0-1418.7 ft (416.16-432.53 m)

The lower vitrophyre, or crystal-poor densely welded vitric subzone, of the Topopah Spring Tuff (vitrophyre zone of Scott and Bonk) is densely welded and vitric, with coarse, black vitric spots formed by relict cognate pumice clasts. Scattered through the vitrophyre are 3 to 5 percent small, rhyolitic lithics, 1 to 2 percent small, red-brown quartz latite lithics, and 3-4 percent phenocrysts. Sanidine dominates the phenocryst assemblage with traces of biotite and accessory magnetite. Lithic fragments are generally less than 0.08 inch $(2 \mathrm{~mm})$ in diameter. A distinctive rectilinear fracturing pattern is attributed to the glassy composition. The style of fracturing changes from predominantly subhorizontal fractures near the top of the unit to vertical fractures at $1404.0 \mathrm{ft}$ (428.05 $\mathrm{m}$ ) associated with an interval containing large blocks of vitric pumice. Strong, horizontal fracturing is present from 1414.0 to $1419.0 \mathrm{ft}$ (431.10 to $432.62 \mathrm{~m}$ ) depth. Pale-blue vapor-phase silica has been deposited on the major joint surfaces.

\section{Moderately welded subzone (Tptpv2)}

1418.7-1445.0 ft (432.53-440.55 m)

The moderately welded vitric subzone (partially welded zone of Scott and Bonk) is distinguished from the overlying vitrophyre in part by the presence of subangular, orange pumice fragments. This zone also is noticeably less welded than the vitrophyre. The matrix is glossy, vitric, and slightly more argillized lower in the unit.
The rock contains phenocrysts of sanidine, quartz and biotite, light-brown vitric pumice clasts about 0.39 inch $(10 \mathrm{~mm})$ in size, and small, lightgray rhyolitic lithics set in a matrix of vitric bubble-wall shards. A lithic-rich interval is present from 1431.5 to $1442.2 \mathrm{ft}$ ( 436.43 to $439.70 \mathrm{~m}$ ). Vitric quartz latite lithics averaging 0.39 to 0.59 inch $(10-15 \mathrm{~mm})$ are prevalent in the upper part of this interval and vitric, light-gray lithics are more common near the base of the lithic zone. Zeolitic alteration first appears at $1432.8 \mathrm{ft}(436.83 \mathrm{~m})$ as a waxy micro-recrystallization of the tuff matrix. Dominantly subhorizontal fracturing is less intense than in the overlying vitrophyre subzone. The intensity of welding decreases downward into the lower nonwelded subzone.

Nonwelded subzone (Tptpv1) 1445.0-1464.1 ft (440.55-446.37 m)

A gradational contact at about $1445.0 \mathrm{ft}$ $(440.55 \mathrm{~m})$ separates the lower nonwelded vitric subzone (partially welded zone of Scott and Bonk) from its more welded overlying neighbor. The nonwelded subzone contains both vitric and zeolitic rocks composed of 35-40 percent light-pink or light-orange pumice fragments that average 0.20 to 0.28 inch ( 5 to $7 \mathrm{~mm}$ ) in diameter. Pumice fragments locally contain spherulites. The rock also contains 2-3 percent red-brown, quartz latite lithics (0.20 inch diameter), and 2-3 percent phenocrysts in a zeolitized, formerly vitric matrix. Phenocrysts include 1-2 percent sanidine, 1-2 percent quartz eyes, traces of biotite and pyroxene, and accessory magnetite. The matrix is speckled by about 2 percent finely crystalline black spots of manganese oxide. A 0.6 inch $(15 \mathrm{~mm})$ thick, very fine-grained ash fall marks the base of the unit.

\section{Pre-Topopah Spring Tuff bedded tuff (Tpbt1)} $1464.1-1479.9 \mathrm{ft}(445.46-451.19 \mathrm{~m})$

The pre-Topopah Spring Tuff bedded tuff is a zeolitized unit topped by a pumice fall containing 70 percent small, dense pumice clasts, $10-12$ percent vesicular pumice, 1-2 percent zeolitic cognate pumice, and 5-7 percent small, dark lithics in an ashy matrix that grades downward into a bedded tuff. The bedded tuff exhibits a sandy, reworked texture, but retains a high ash content. The reworked tuffaceous material is composed of $25-$ 
30 percent pumiceous and non-pumiceous clasts. Many of the clasts have opaline color and conchoidal or angular shapes. Approximately 35-40 percent of the core is cognate pumice and 3 percent is dark, quartz latite lithic fragments. A coarsegrained pumice fall is present from a depth of 1477.0 to $1479.9 \mathrm{ft}$ ( 450.30 to $451.19 \mathrm{~m})$, becoming lithic-rich (20-30 percent lithic clasts) below $1478.7 \mathrm{ft}(450.82 \mathrm{~m})$.

\section{Calice Hills Formation (Tac)}

\section{Calico Hills ash-flow unit 3 (Tac3)} 1479.9-1764.4 ft (451.19-537.93 m)

The uppermost Calico Hills unit in this hole, ash-flow unit 3 of Moyer and Geslin (1995), is capped by a weakly reworked zone that probably represents a paleosol. This pyroclastic flow deposit is partially clast-supported and is composed of an altered matrix containing 35-40 percent partially zeolitized pumice clasts. The rock also contains 12 percent phenocrysts of feldspar, quartz with traces of biotite and sericite and up to 3-5 percent lithic fragments of mixed composition, mostly of quartz latite. Between 1483.7 and $1487.6 \mathrm{ft}$ (452.35 to $453.54 \mathrm{~m}$ ) in depth, the lithic content increases to around 5-7 percent. The diameter of these lithic fragments increases concurrently to an average of 0.31 inch $(8 \mathrm{~mm})$. Zeolitization increases downward, becoming noticeably more intense between a depth of 1572.0 and $1574.0 \mathrm{ft}$ (479.27 to 479.88 $\mathrm{m})$, associated with a crowded zone of larger lithics. A lithic-rich pumice fall, also exhibiting increased zeolitization, marks the bottom of unit 3 .

\section{Calico Hills ash-flow unit 2 (Tac2) $1586.1-1737.5 \mathrm{ft}$ (483.57-529.73 m)}

Ash-flow tuff unit 2 of the Calico Hills Formation is similar to the overlying unit 3 , except that the pumice content decreases to 15-25 percent, and the lithic content also decreases to 1-2 percent redbrown and red-orange fragments of varying composition. Pumice fragments are generally smaller than 0.59 inch $(15 \mathrm{~mm})$ in diameter, but may be up to 2.56 inch $(65 \mathrm{~mm})$ across. Phenocrysts, including feldspar, quartz and minor amounts of biotite compose 1-2 percent of the core above about 1600 $\mathrm{ft}(487.80 \mathrm{~m})$, and $2-4$ percent below that depth. The matrix is heavily zeolitized, exhibiting an orange-pink, gray color; the intensity of alteration appears to increase downward. Subtle bedding breaks in the form of very thin ash or pumice falls are present at $1685.2 \mathrm{ft}(513.78 \mathrm{~m}), 1704.0 \mathrm{ft}$ $(519.51 \mathrm{~m})$, and $1708.5 \mathrm{ft}(520.88 \mathrm{~m})$. At $1735.0 \mathrm{ft}$ $(528.96 \mathrm{~m})$, ash- and pumice-fall deposits form the base of the unit.

\section{Calico Hills ash-flow unit 1 (Tac1) 1737.5-1764.4 ft (529.73-537.93 m)}

Ash-flow unit 1 is a highly zeolitized pyroclastic-flow deposit containing 15-25 percent pumice fragments, 3-5 percent red-brown lithics of varying composition and texture, and 3-5 percent phenocrysts of feldspar, quartz and lesser biotite. The proportions of phenocrysts and red-brown lithics increase to 7-10 percent and 10-15 percent, respectively, below a very subtle bedding break at $1750.1 \mathrm{ft}(533.57 \mathrm{~m})$. Yellow-gray pumice clasts are generally smaller than 0.79 inches $(20 \mathrm{~mm})$ diameter and increase in abundance to 20-25 percent below $1750.1 \mathrm{ft}$. The matrix appears intensely altered to zeolites and is an orange-pink-gray color. The base of the unit is marked by a 2.4-inch (61 $\mathrm{mm}$ ) thick pink ash bed.

\section{Calico Hills bedded tuff unit (Tacbt) 1764.4-1803.4 ft (537.93-549.82 m)}

The upper $3.8 \mathrm{ft}(1.16 \mathrm{~m})$ of the "bedded tuff" deposit that precedes the Calico Hills tuffs is a heavily zeolitized ash-flow tuff containing 7 to 10 percent white pumice fragments, 10-15 percent quartz, feldspar, and minor biotite phenocrysts, and 10 percent small, red-brown lithic clasts. The remainder of the deposit is composed of zeolitized pumice-fall or ash-fall deposits. The intensity of zeolitic alteration decreases downward toward the base of the unit. A fine-grained pumice fall containing distinctive pale-pink to yellow-gray pumice clasts is present from 1768.2 to $1775.1 \mathrm{ft}(539.09$ to $541.19 \mathrm{~m}$ ), and is underlain by an altered, porcelaneous ash-fall deposit. Two coarse-grained pumice falls were cored between 1775.1 and $1799.4 \mathrm{ft}$ ( 541.19 to $548.60 \mathrm{~m}$ ). The upper pumice fall has a weakly reworked top, is heavily zeolitized from 1773.3 to $1780.6 \mathrm{ft}$ (540.64 to 542.87 $\mathrm{m})$. The unit is thinly bedded between 1776.7 and $1778.6 \mathrm{ft}$ ( 541.68 to $545.26 \mathrm{~m})$. The lower pumice fall, the upper 6-ft $(1.83-\mathrm{m})$ of which appears to have been reworked, becomes coarser and more 
pumice- and biotite-rich downward. The base of the lower pumice-fall unit between 1797.8 and $1799.4 \mathrm{ft}$ (548.11-548.60 m) appears bedded and has been intensely zeolitized. A thin, poorly sorted pumice fall with a thin, reworked top extends to the lower contact at $1803.4 \mathrm{ft}(549.82 \mathrm{~m})$.

\section{Calico Hills basal tuffaceous sandstone (Tacbs) 1803.4-1820.7 ft (549.82-555.09 m)}

The lowermost unit of the Calico Hills Formation was defined by Moyer and Geslin (1995) as a red-brown, immature, tuffaceous sandstone. This unit was encountered by the SD-9 drill hole between depths of 1803.4 and $1820.7 \mathrm{ft}$ (549.82$555.09 \mathrm{~m}$ ). The upper part of the unit to a depth of $1810.7 \mathrm{ft}(552.04 \mathrm{~m})$ is characterized by intervals of subrounded, reworked pumice clasts in a pale, red-brown sandstone. This interval is separated from the lower part of the unit by a thin, dark redbrown sandstone bed exhibiting load casts at $1811.5 \mathrm{ft}(552.29 \mathrm{~m})$. The lower sandstone interval $(1811.5-1820.7 \mathrm{ft}, 552.29-555.09 \mathrm{~m})$ is pale-redbrown and contains 5-10 percent altered pumice fragments. A fine-grained, thinly bedded interval between 1813.9 and $1817.5 \mathrm{ft}(553.02-54.12 \mathrm{~m})$ is devoid of pumice.

\section{Prow Pass Tuff (Tcp)}

\section{Prow Pass ash-flow unit 4 (Tcp4)} $1820.7-1868.7 \mathrm{ft}(555.09-569.73 \mathrm{~m})$

Ash-flow unit 4 of the Prow Pass Tuff is a finegrained, heavily zeolitized ash-flow tuff with yellow-gray mottling. A weak paleosol or weathering surface is developed in the uppermost $2.3 \mathrm{ft}(0.70$ $\mathrm{m})$. The rock contains $2-3$ percent white pumice clasts that are predominantly less than 0.39 inch $(10 \mathrm{~mm})$ in diameter; $3-5$ percent phenocrysts of quartz, feldspar, traces of biotite, and rare pyroxene; and 2-3 percent small, lithic fragments that vary widely in composition. The percentage of pumice fragments increases at $1841.1 \mathrm{ft}(561.31 \mathrm{~m})$ to 7-10 percent pumice less than 0.59 inch (15 $\mathrm{mm}$ ) in diameter; phenocrysts also increase to 5-7 percent. At $1845.8 \mathrm{ft}(562.74 \mathrm{~m})$ depth, pumice clasts increase in size to as much as 1.97 inch (50 $\mathrm{mm}$ ) in diameter, and phenocrysts increase to 10 12 percent. Red-brown, angular siltstone lithic fragments are commingled with the more usual lithic assemblage below about $1845.8 \mathrm{ft}$. Bedding breaks are present at $1832.7 \mathrm{ft}(558.75 \mathrm{~m}), 1835.8$ $\mathrm{ft}(559.70 \mathrm{~m})$, and $1836.0 \mathrm{ft}(559.76 \mathrm{~m})$. A slight increase in welding at $1860.2(567.13 \mathrm{~m})$ is possibly associated with weak vapor-phase silicification. Fracturing is dominantly subhorizontal, except in the upper $16 \mathrm{ft}(4.89 \mathrm{~m})$ of the unit where vertical joints are common.

\section{Prow Pass ash-flow unit 3 (Tcp3) 1868.7-2015.8 ft (569.73-614.57 m)}

Ash-flow unit 3 is distinguished principally by the presence of vapor-phase alteration and incipient welding. The rock is composed of 10-20 percent pumice clasts up to 1.38 inch $(35 \mathrm{~mm}$ ) diameter, 3-5 percent phenocrysts of quartz, feldspar, biotite, and pyroxene, and 2-3 percent small, mixed composition lithic fragments including a red siltstone variety. The upper $3 \mathrm{ft}(1 \mathrm{~m})$ of this heavily zeolitized ash-flow unit has been vaporphase altered and contains clasts exhibiting vaporphase replacement of cellular pumice. From about 1897 to $2012 \mathrm{ft}$ (578.35-610.18 m), the tuff is partially welded with a heavily zeolitized, microgranular matrix. Large pumice fragments are slightly flattened and rimmed by vapor-phase alteration minerals surrounding a darker, typically vuggy core. Small angular lithics exhibit hazy halos of vapor-phase alteration products. The intensity of vapor-phase alteration decreases beginning at about $1930 \mathrm{ft}(588.41 \mathrm{~m})$. Below an interval of noticeably decreased welding and weaker vaporphase alteration between 1989 and $2002 \mathrm{ft}$ $(606.22-610.18 \mathrm{~m})$, welding and vapor-phase alteration are absent below $2012 \mathrm{ft}(613.23 \mathrm{~m})$. Irregularly spaced vertical joints are common.

\section{Prow Pass ash-flow unit 2 (Tcp2) 2015.8-2985.3 ft (614.57-910.15 m)}

Ash-flow unit 2 is a zeolitized, nonwelded ashflow tuff similar to unit 3 except that the lithic content is higher, approximately 5 to 15 percent. A pale-orange matrix exhibits brown alteration, particularly along the margins of lithic clasts. Partially to totally zeolitized pumice fragments are 0.16 to 0.59 inch ( 4 to $15 \mathrm{~mm}$ ) in diameter, undeformed, and constitute 20 to 40 percent of the rock. Most lithics are large, up to 0.98 inch $(25 \mathrm{~mm})$ in diameter, and of a dense, red-brown igneous rock or red siltstone. Two lithic-rich zones occur at $2018.1 \mathrm{ft}$ 
and $2020.9 \mathrm{ft}(615.27$ and $616.13 \mathrm{~m})$. A noticeable decrease in average lithic size occurs at $2022.8 \mathrm{ft}$ $(616.71 \mathrm{~m})$ and the size distribution is bimodal. Fragments $0.20-0.98$ inches $(5-25 \mathrm{~mm}$ ) across compose 1-2 percent of the rock, and clasts less than 0.20 inch $(5 \mathrm{~mm})$ form approximately $2-4$ percent). A subtle bedding break may be present at $2047.0 \mathrm{ft}(624.09 \mathrm{~m})$, where the phenocryst content changes abruptly downward from 5-10 percent to 10-12 percent. Phenocrysts include feldspar, quartz, oxybiotite, and pseudomorphs after pyroxene. The lower two-thirds of the unit is more intensely zeolitized, exhibiting patchy green-brown alteration of the bulk rock; green speckles of zeolite may be observed in the cores of pumice fragments.

\section{Prow Pass ash-flow unit 1 (Tcp1)}

2095.3-2223.1 ft (638.81-677.77 m)

Ash-flow unit 1 is an essentially nonwelded, heavily zeolitized unit, containing 25-27 percent altered, subangular pumice clasts in the 0.12 to 0.39 inch $(3-10 \mathrm{~mm})$ diameter size range. The pumice fragments are dense and laminated, and are almost completely altered to zeolite; some fragments retain relict froth structure. The rock also contains 1-3 percent small, angular, red-brown volcanic or red-siltstone lithics, and phenocrysts comprised of 2-3 percent quartz, 1-2 percent sanidine, 0.5 percent pyroxene, and 1.0 percent biotite. Secondary porosity increases downward with increasing zeolitic alteration. Two ash-flow boundaries located at $2122.8 \mathrm{ft}(647.20 \mathrm{~m})$ and $2125.8 \mathrm{ft}$ $(648.11 \mathrm{~m})$ are marked by thin, ash-rich partings. The SD-9 drill hole stopped short of the base of ash-flow unit 1. 


\section{Appendix B: Geologic Core Logs}




\section{Geologic Core Logs}

The geologic core logs in this appendix are reproduced in color at their original full scale of $1: 120$ ( 1 inch equals 10 feet). Full-size reproduction means that the log sheets that follow have not been formatted or numbered in the same manner as the remainder of this document, although the page count of this report is continuous and the log-sheet pages are themselves numbered consecutively. Copies of the original log forms may be retrieved from the Yucca Mountain Project records system under data-tracking number SNT02052794001.003.

The log form (figure B-1) contains a graphic representation of the actual geology of the core. Bedding within reworked units, clasts representing lithic fragments, lithophysal cavities, fractures, and similar textural features are drawn in a "cartoon," but still highly realistic, fashion. For example, large lithophysal cavities are drawn larger than small cavities, and flattened cavities in the core are represented as more oval features than spherical lithophysae. Near-vertical fracturing is represented by stylized fracture lines nearly parallel to the depth axis of the diagram, as such jointing is nearly parallel to the core axis in an essentially vertical drill hole, such as USW SD-9.

The degree of welding, devitrification, and the intensity of secondary alteration of the core is represented semiquantitatively by several parallel bars of vertically varying width. A blank column represents "no alteration" of the indicated type; a fully shaded column indicates "extremely intense alteration." This style of presentation can be very exact over short core distances (feet to tens of feet) and it allows relatively subtle, small-scale variation in these phenomena to be represented quite precisely. The gradational nature of several lithostratigraphic "contacts" becomes quite obvious in this manner. The representation, however, is not rigorously quantitative, and a 3-mm-wide bar at one depth should not be presumed to represent precisely the same intensity of that phenomenon as a 3-mmwide bar several hundred feet away. Note that the type of alteration indicated by a particular column may change with depth to conserve space on the log form; the column headings are kept consistent over broad depth ranges, however.

Engineering and geologic information related to the core itself is also presented on the log sheets. Highly broken or rubblized zones are indicated by a shaded pattern in the fracturing column, and intervals of core loss are indicated by arrows extending through the indicated interval of nonrecovery. The geology of these unrecovered intervals has been interpreted through the intervals of core loss where there is reasonable evidence for such an interpretation (for example, down-holevideo imagery or a relatively consistent lithology in a known, thick geologic unit). Large intervals of lost core in geologic units known from outcrop or other drill holes to be highly variable vertically have been left uninterpreted. Note that drilling support staff assigned lost-core intervals by convention to the bottom of the core run, whereas the actual core loss may have occurred at multiple levels during the drilling of a particular run. Quantitative information (varying from 0 to 100 ) for perrun core recovery and 10 -ft-composite, drillingsupport Deere RQD values (from tables C- 1 and D2) are presented in columns to the right of the geologic descriptions.

The framework material properties, porosity and bulk density, are presented in similar columnar-graphic form to the right of the core-recovery and RQD information. Saturated hydraulic conductivity information does not present well because the wide (orders-of-magnitude) variability of this framework property requires a logarithmic scale; these values have been omitted from the core log. Saturation values, however, have been included as this information may bear on the identification of geologic controls of perched-water bodies. These graphic representations of materials-property data contain quantitative information. Porosity values are scaled from 0 to 70 percent, bulk density values are scaled from 1.0 to $3.0 \mathrm{~g} / \mathrm{cm}^{3}$, and saturation is scaled from 0 to 1 . The locations of changes in the porosity and density of core samples clearly indicate that the boundaries between material property units do not correspond exactly to the boundaries of the different formation-level lithostratigraphic units (Tiva Canyon Tuff, Topopah Spring Tuff). 


\section{COLLAR COORDINATES:}

N 767998.5 E 561818.0

STARIED: MOY 19, 1994

COMPLETED: September 27, 1994

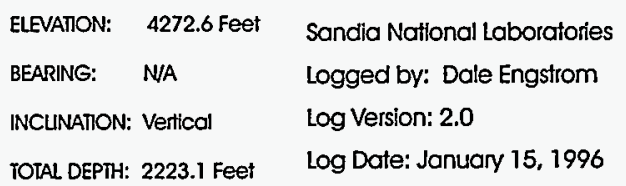

Depth measured in feet

DEPTH

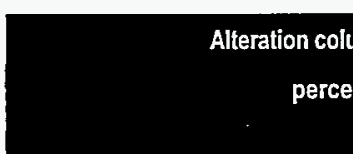

percentage of tithophysae (maximun

amount of macroscopic vapor phase alteration

macroscopic level of devitrification of volcanic glass

macroscopic estimation of degree of welding

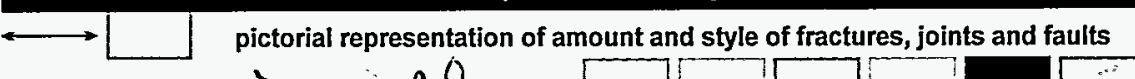

$\rightarrow 00$

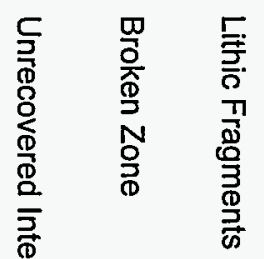

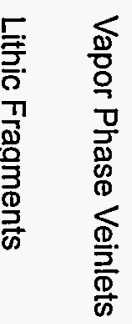
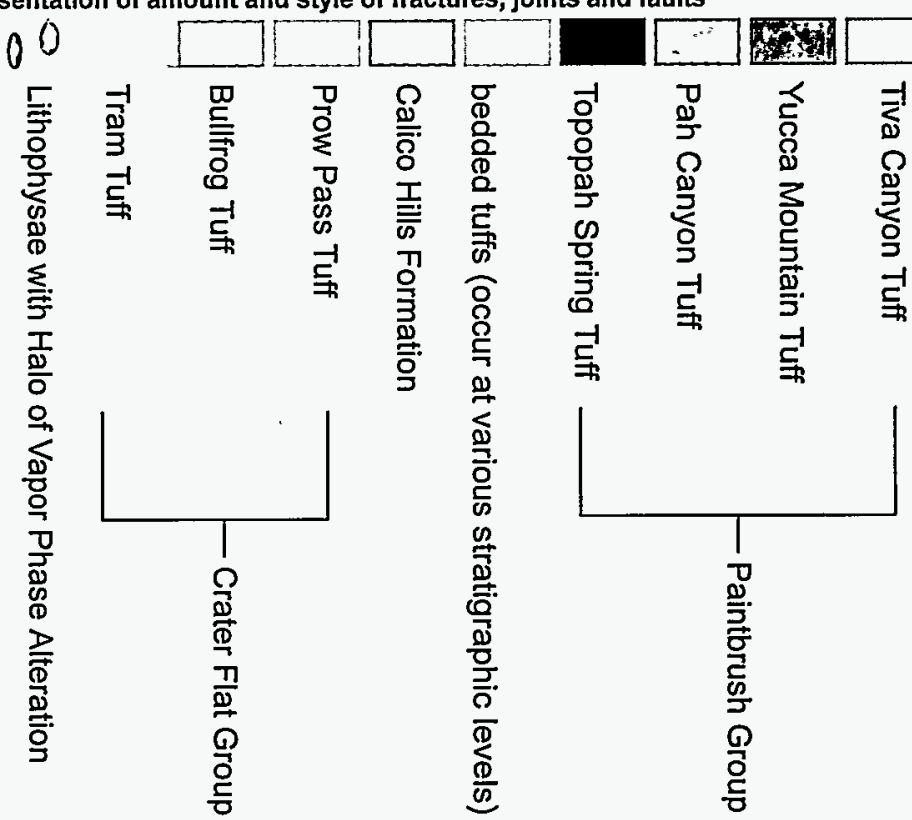

Yucca Mountain Project

Hole No: USW SD-9

Scale: $1^{\prime \prime}=10^{\prime}(1: 120)$

Sheet \# OF 32

ARGILIC

ITHOPH.

VAPOR PH, 2

Destitificotion

WELDING

FRACTURING

GEOLGY

1

ฏ̊

咅

웋

은

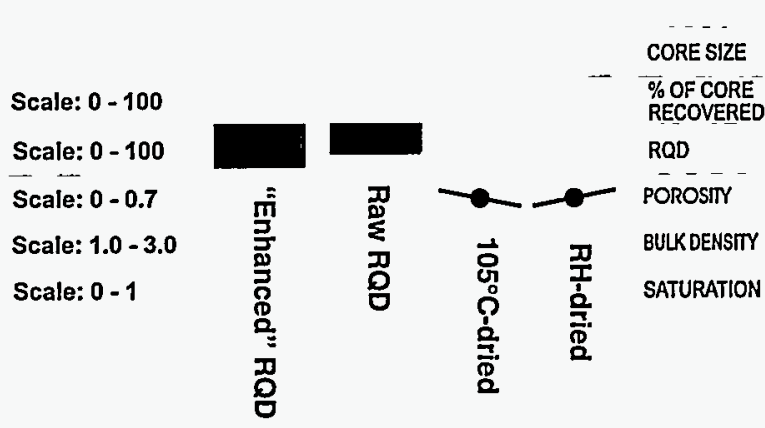


(This page intentionally left blank.)

Note: The color geologic log sheets that follow are single sided. 


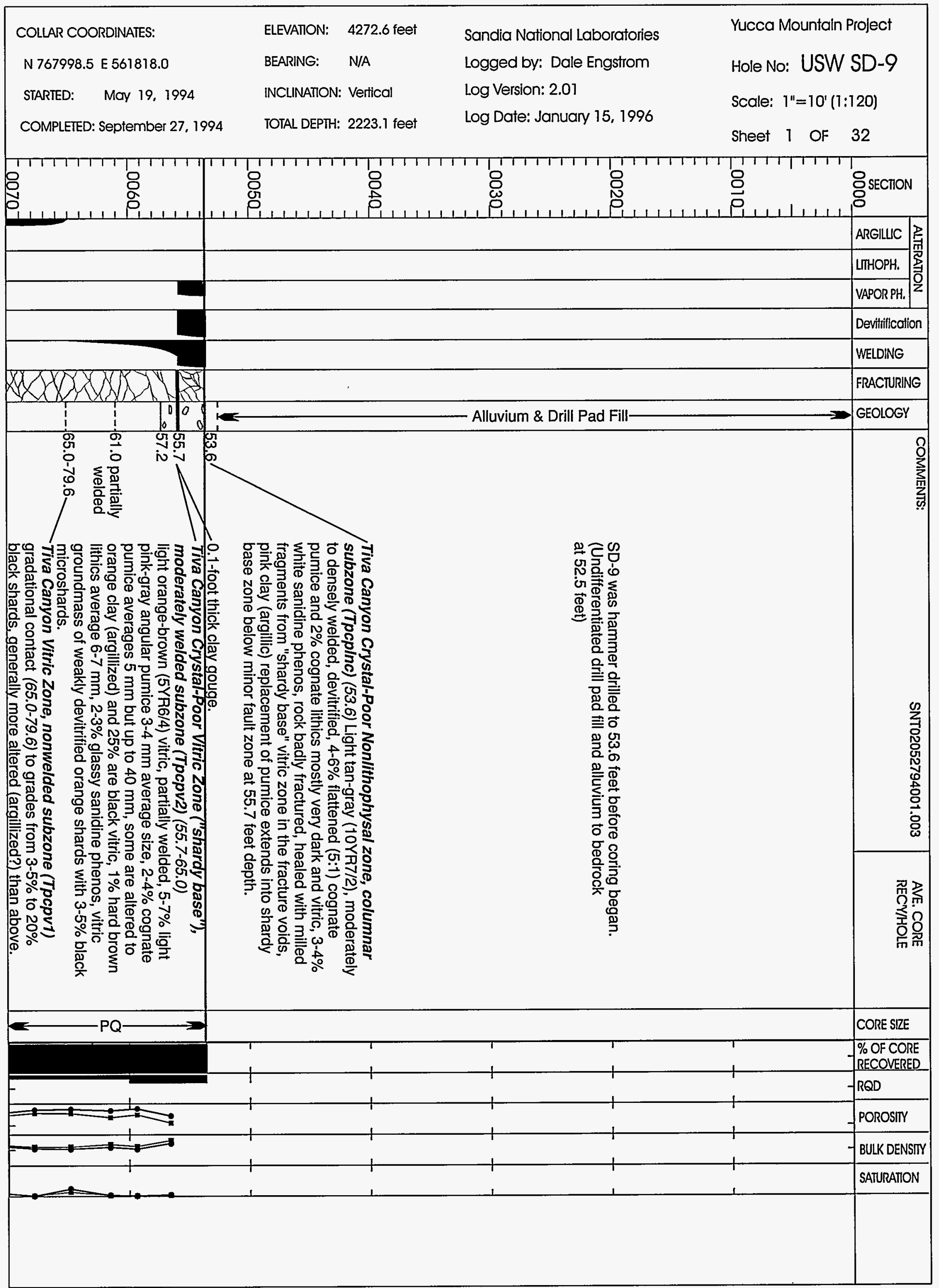





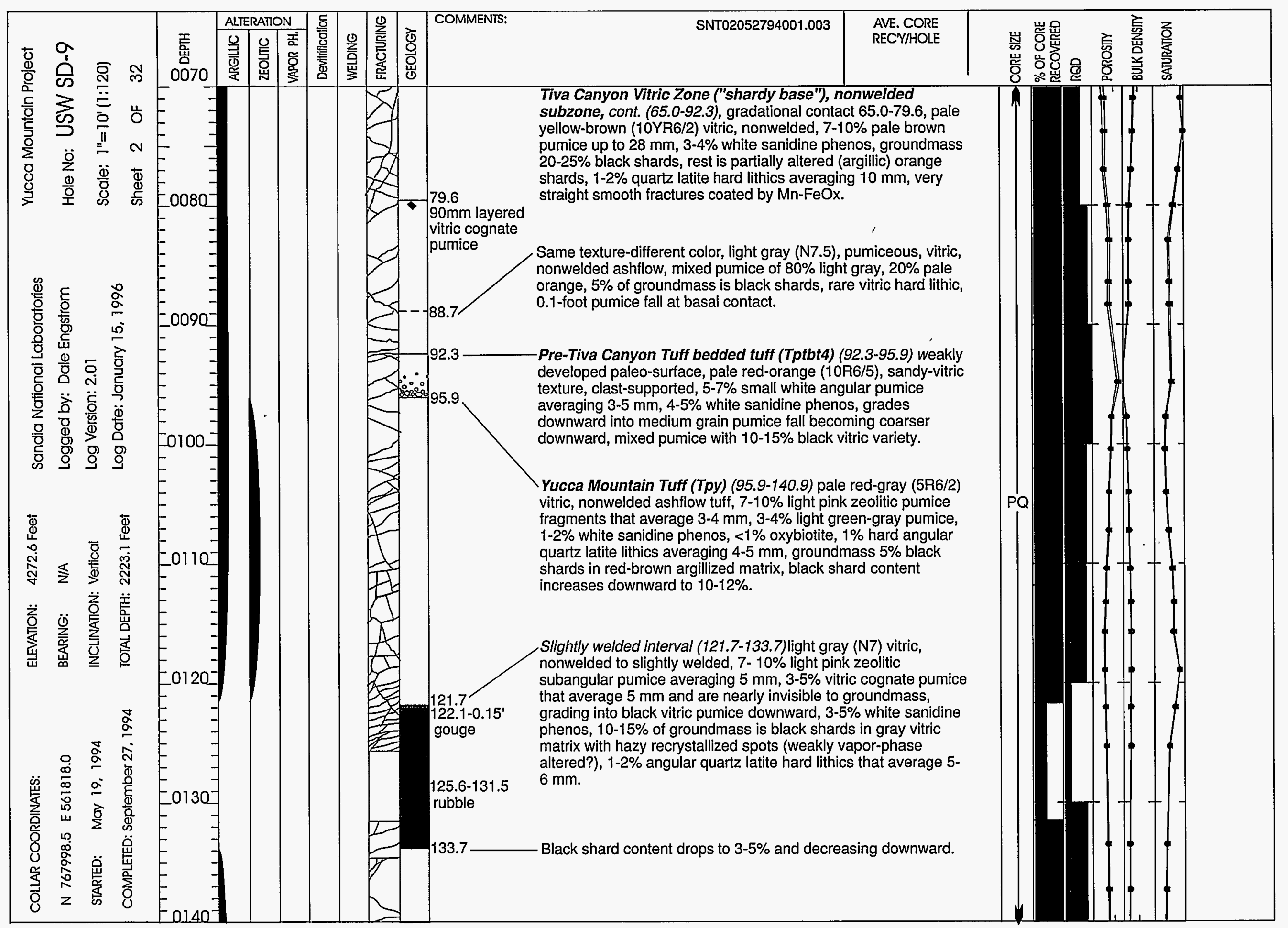




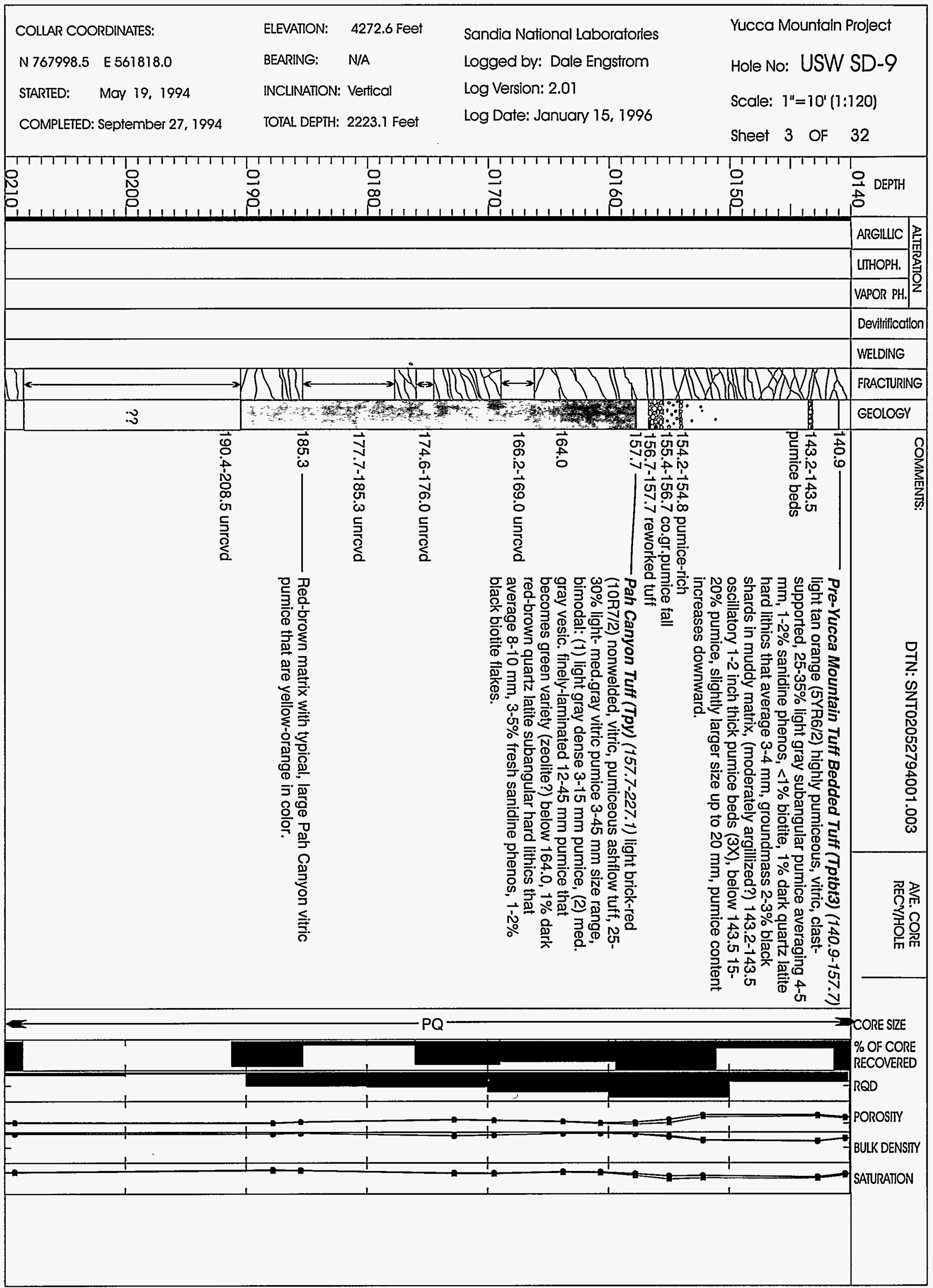




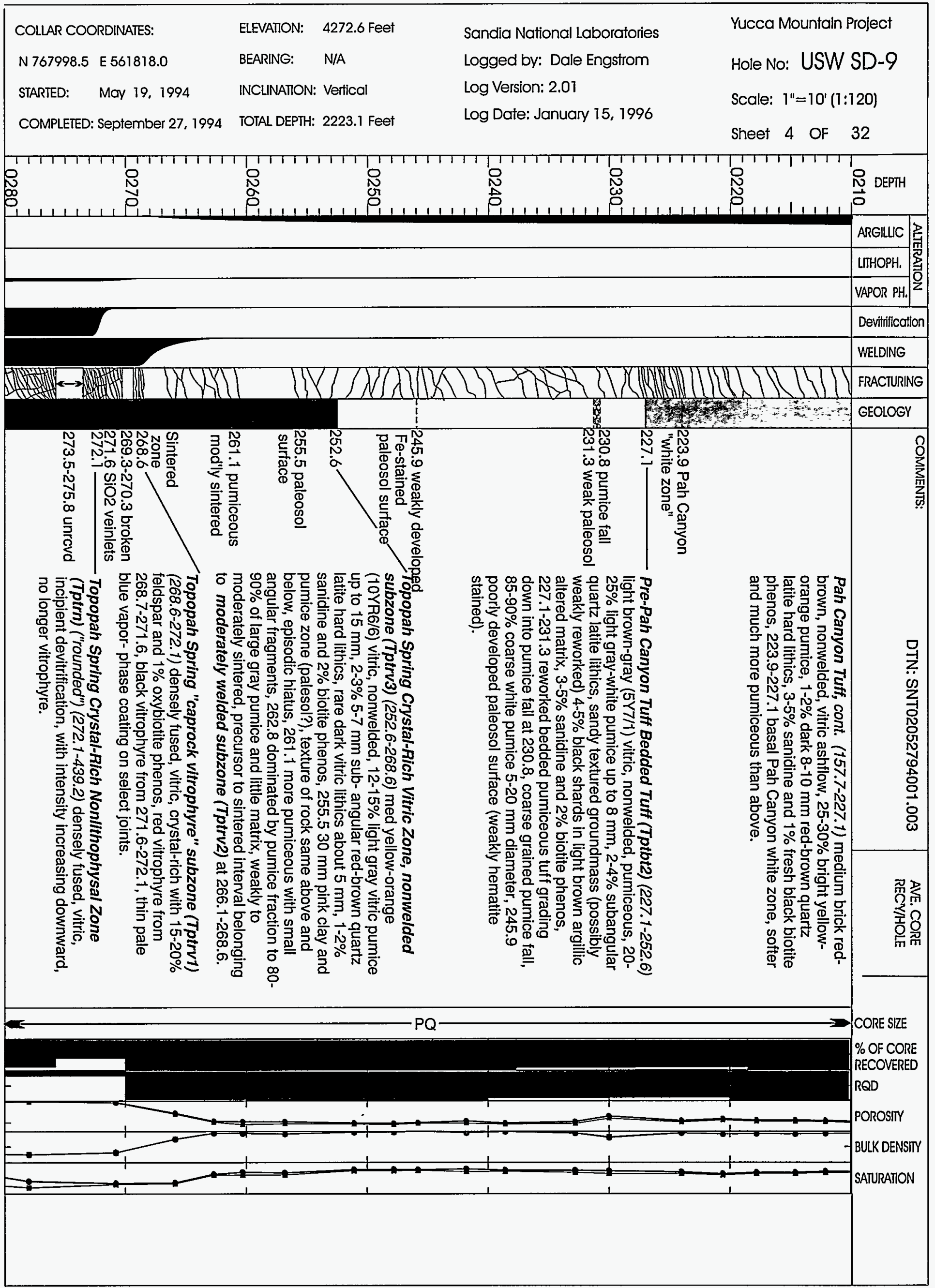




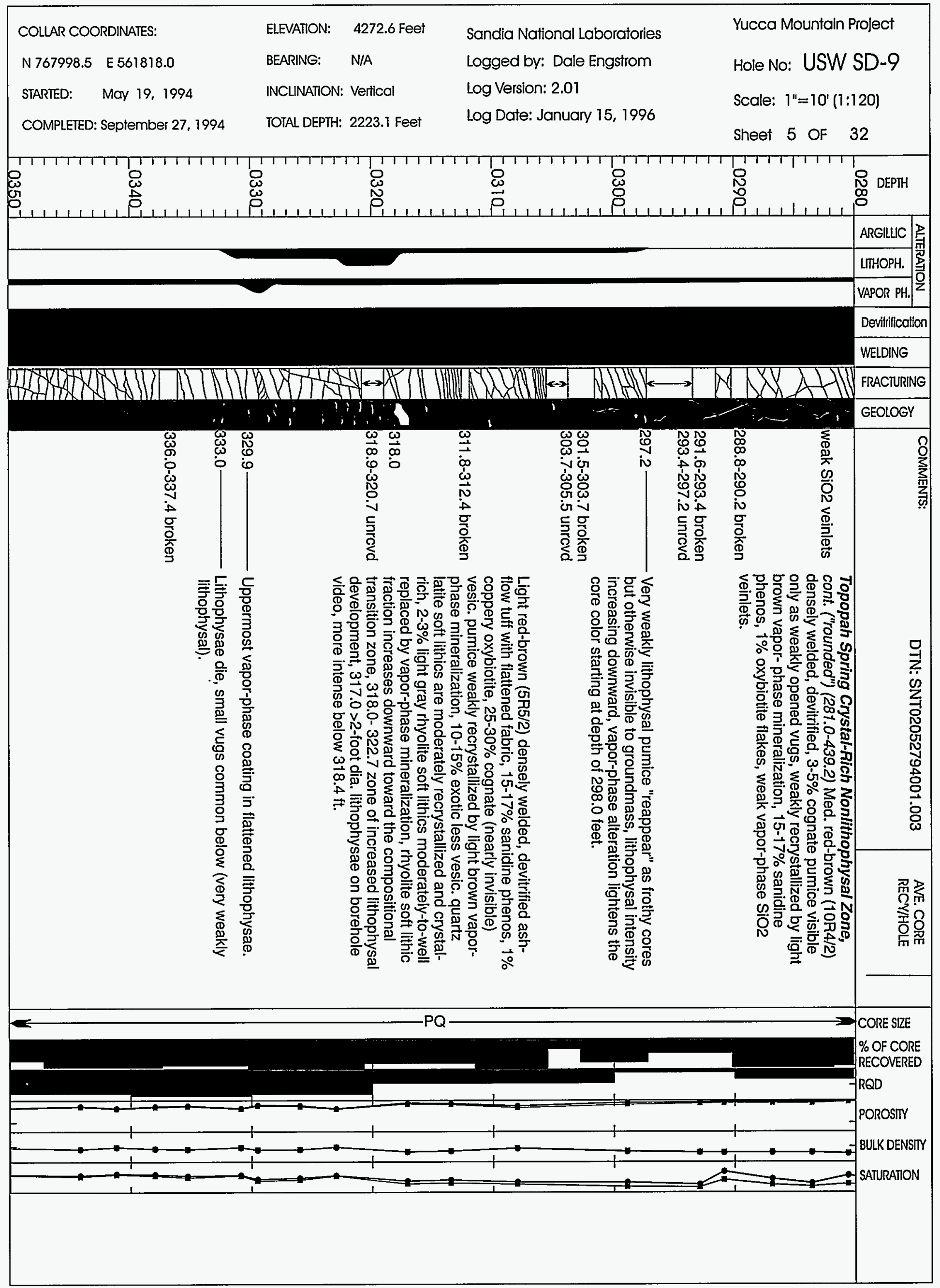




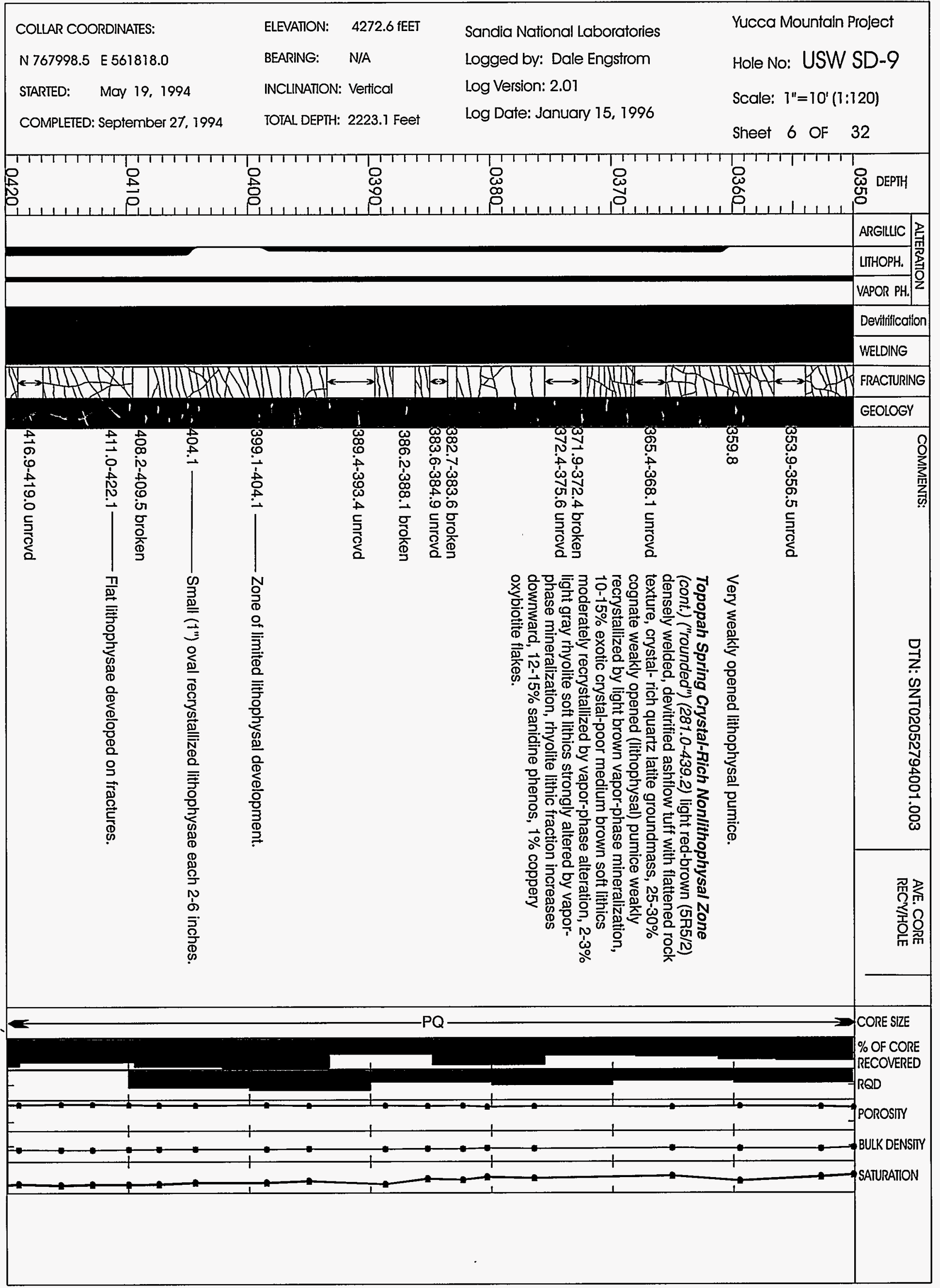




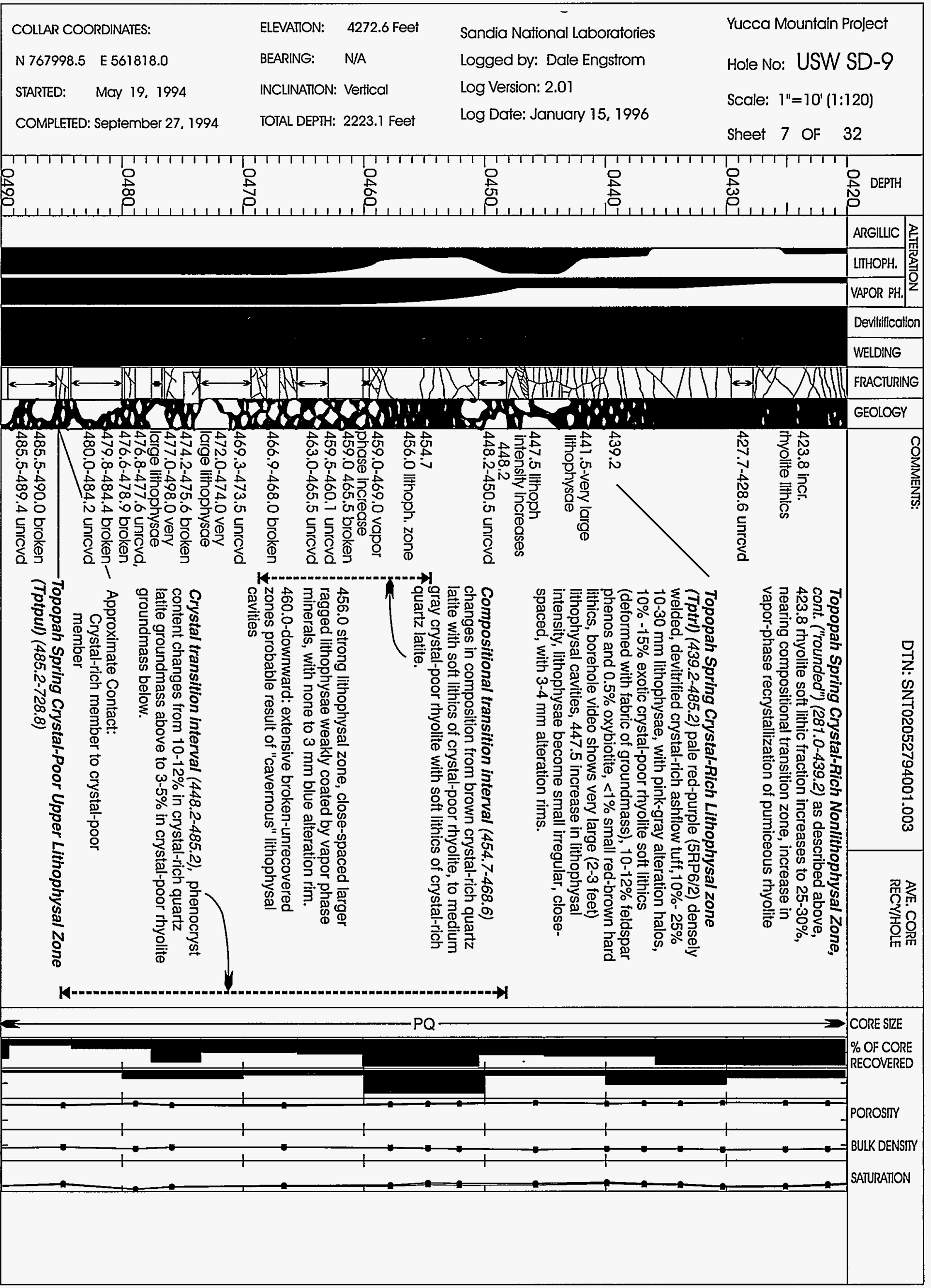




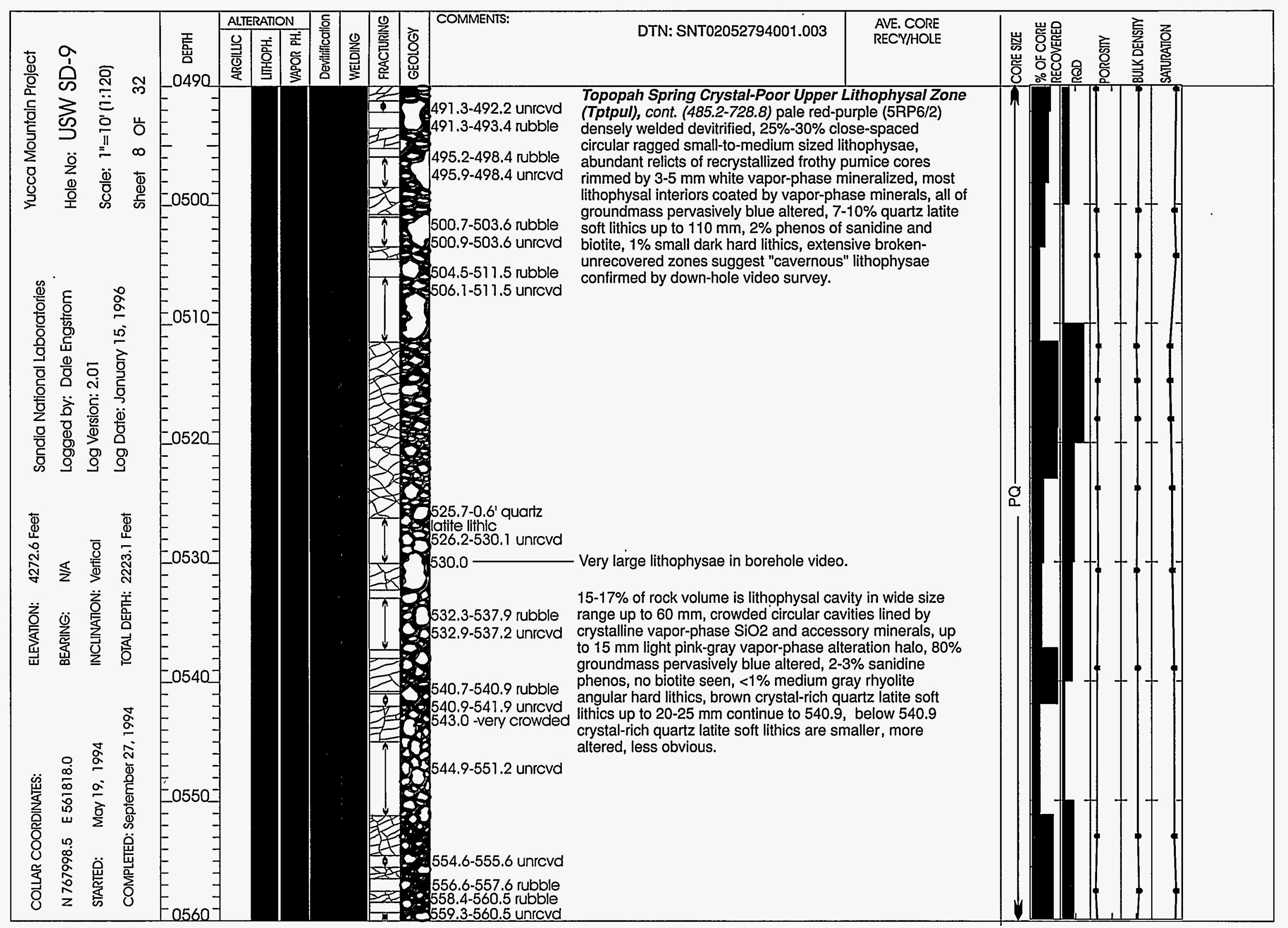




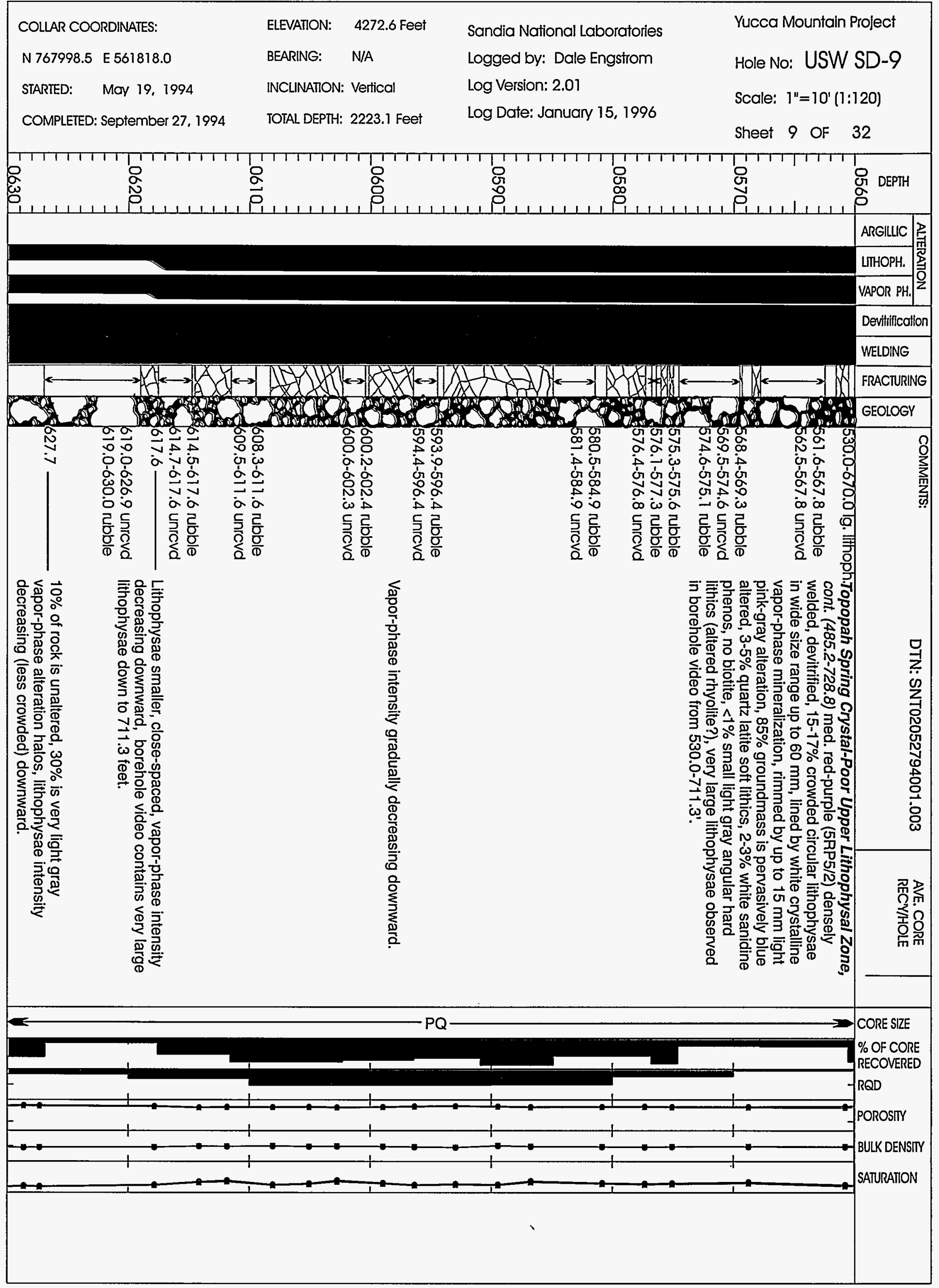




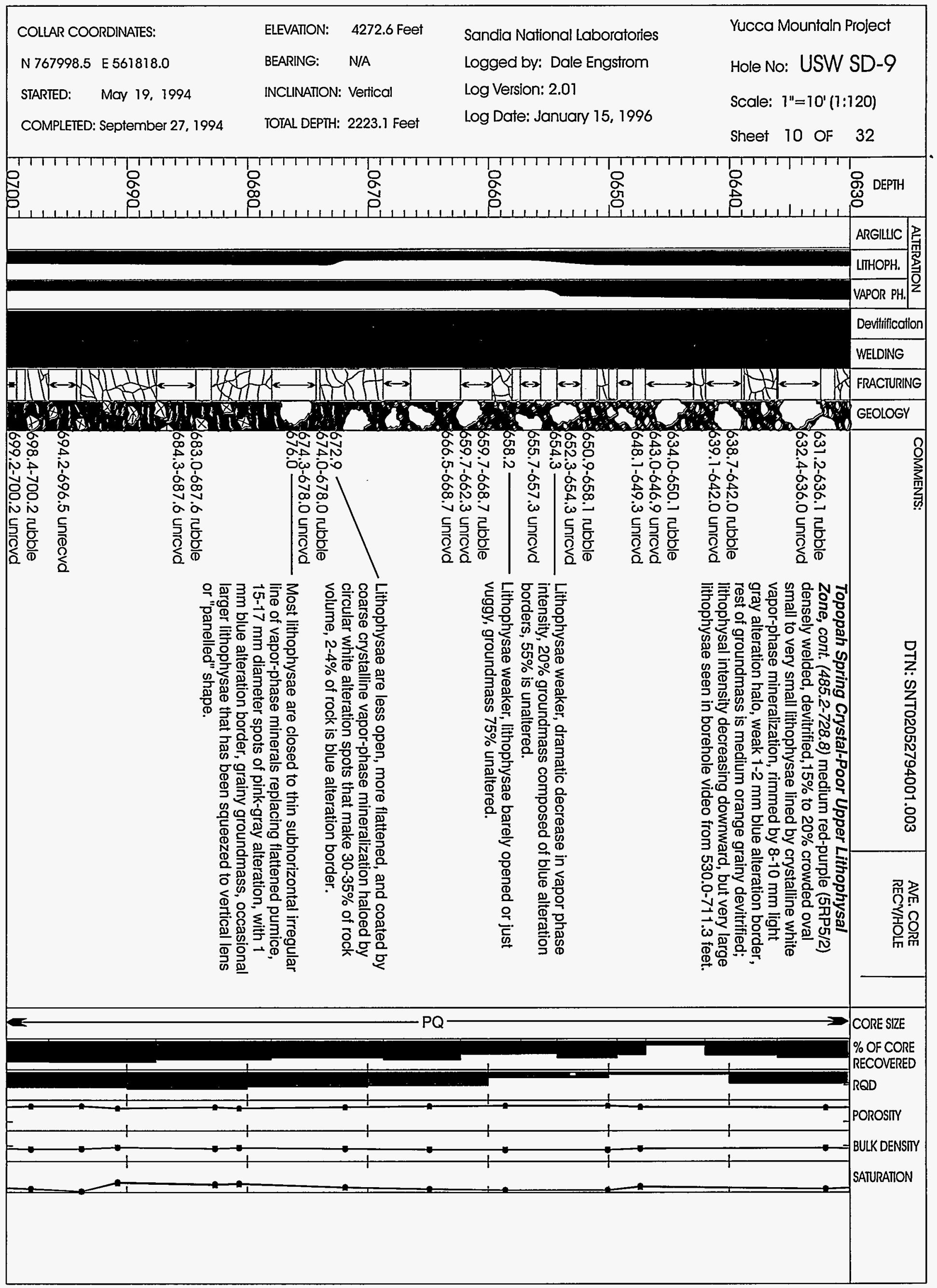




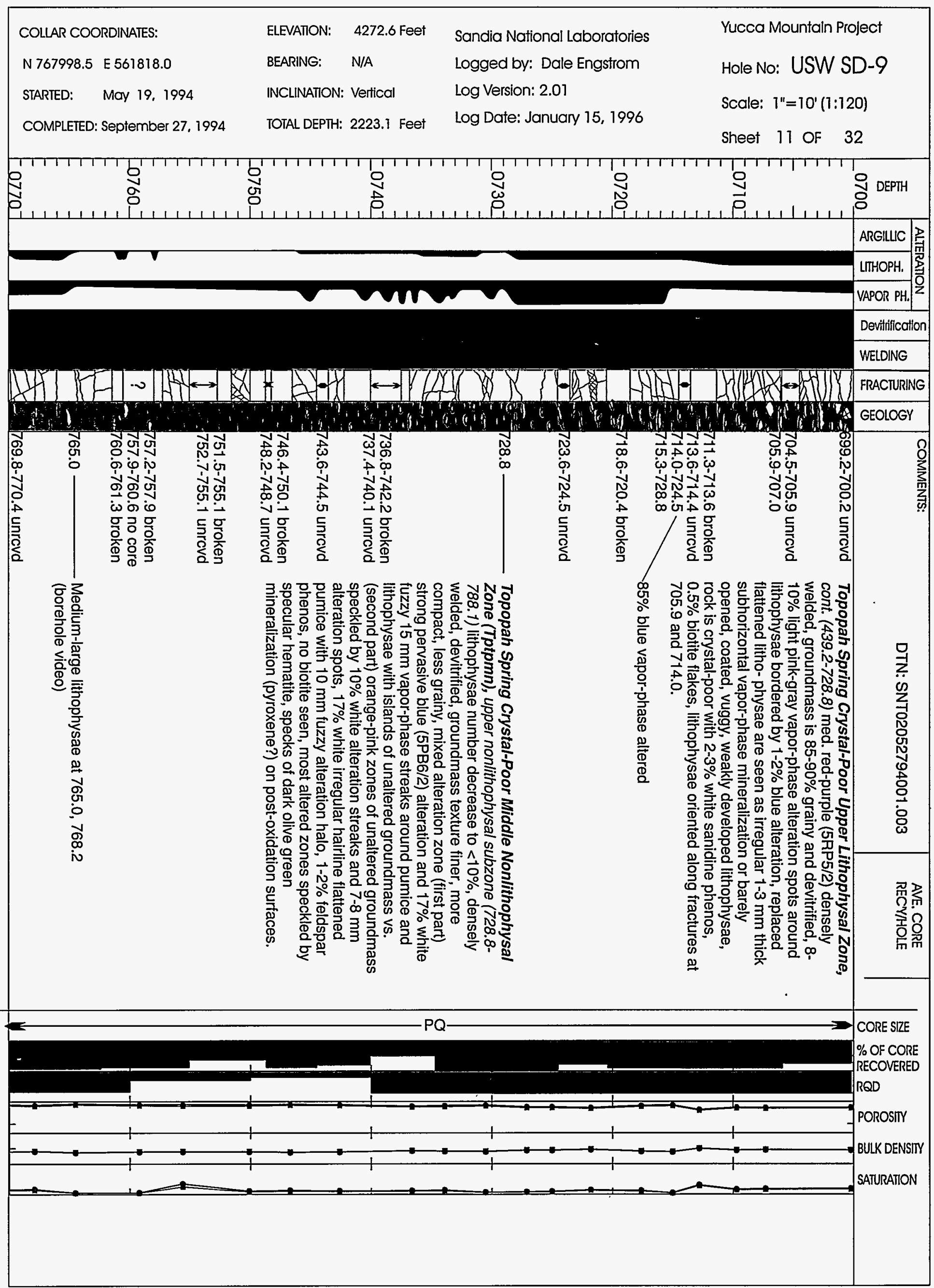




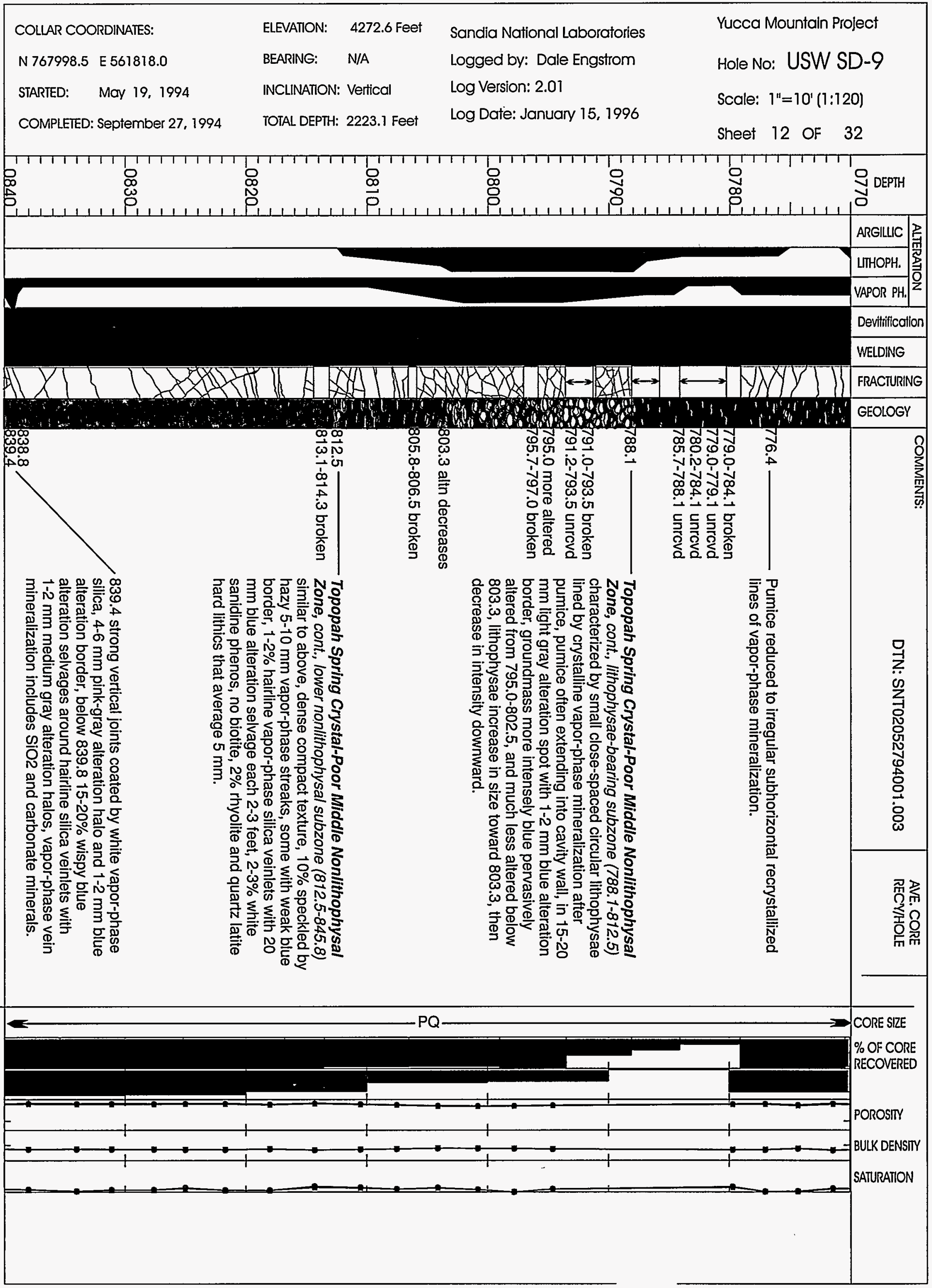




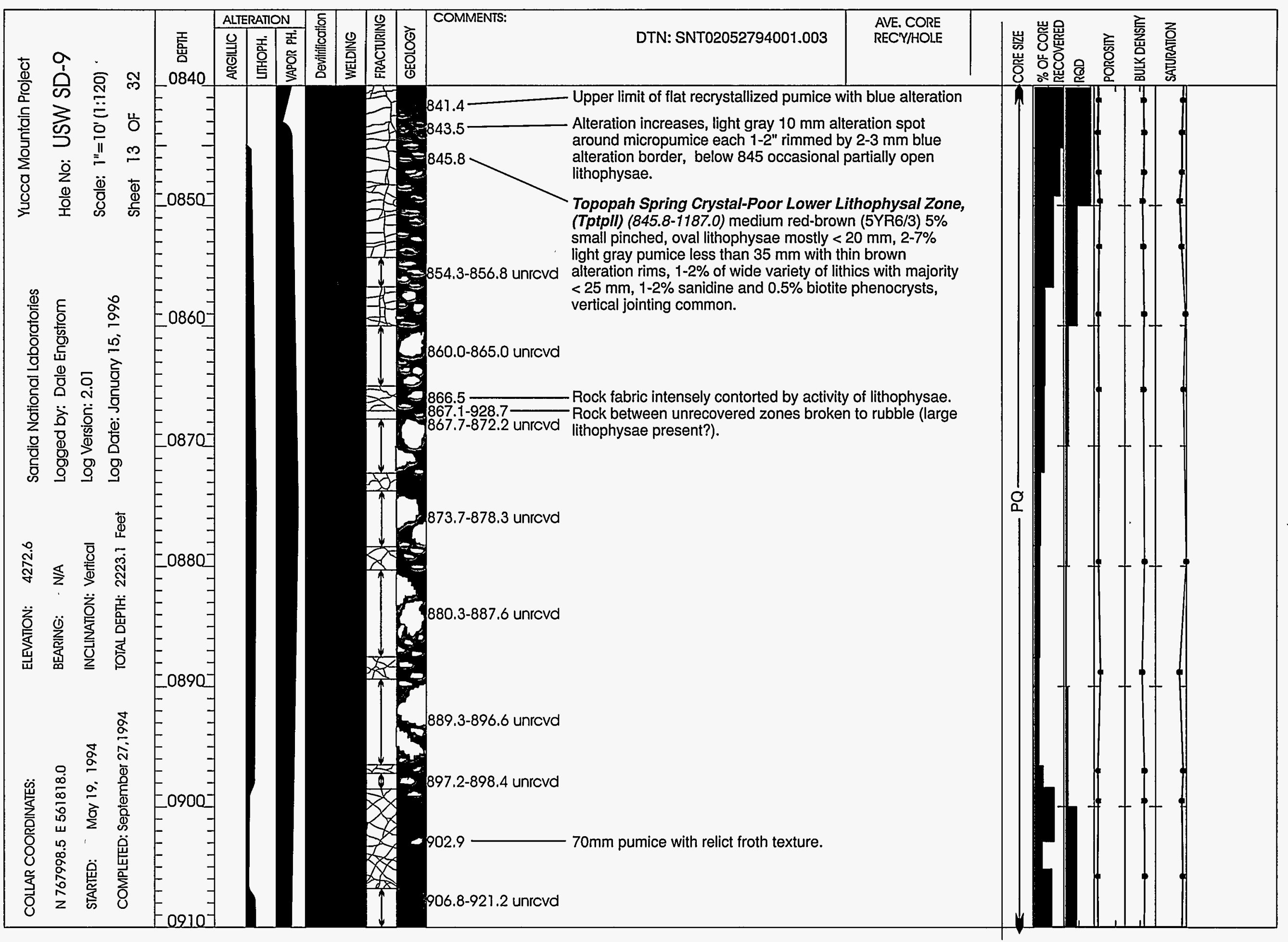




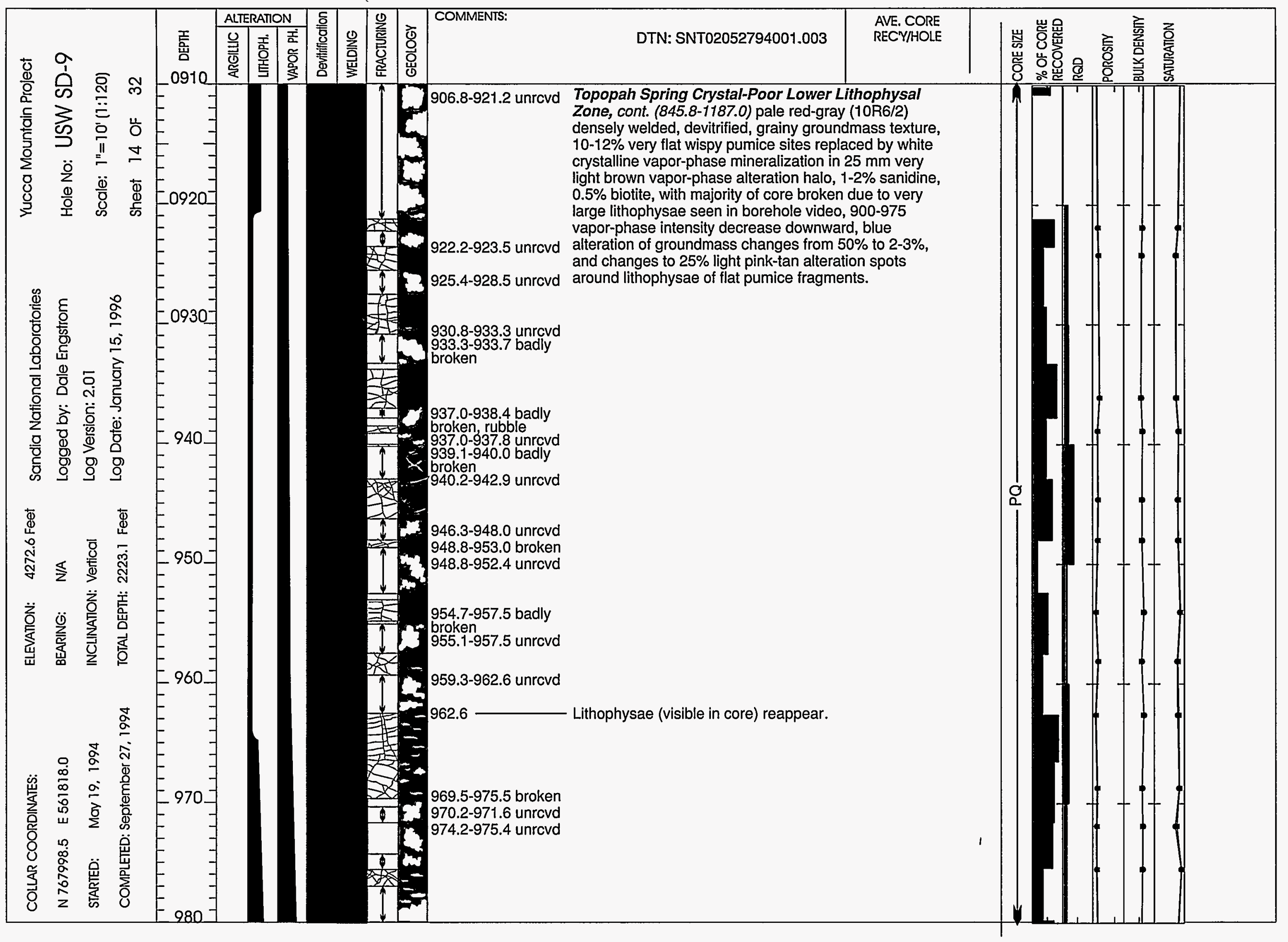




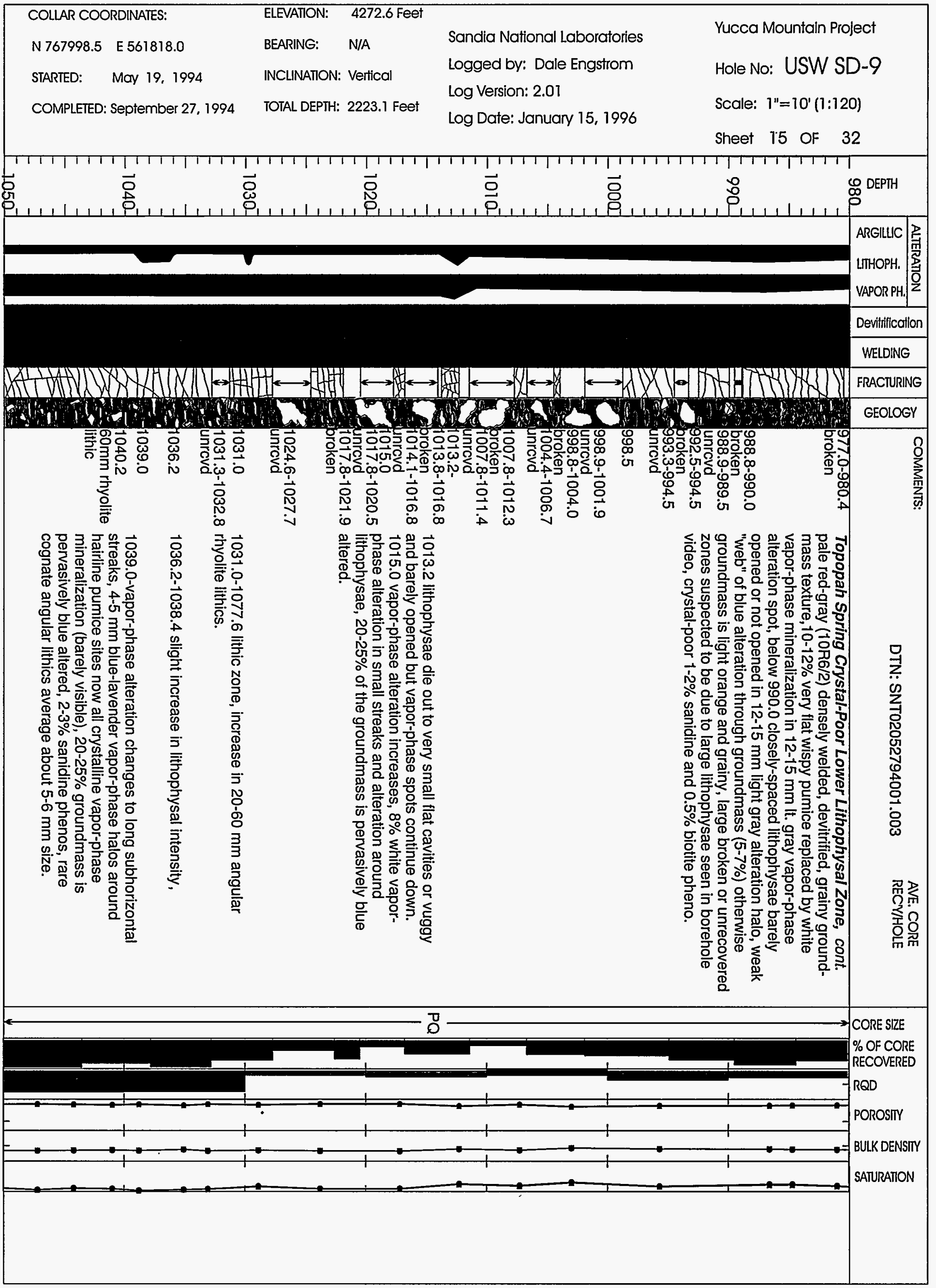




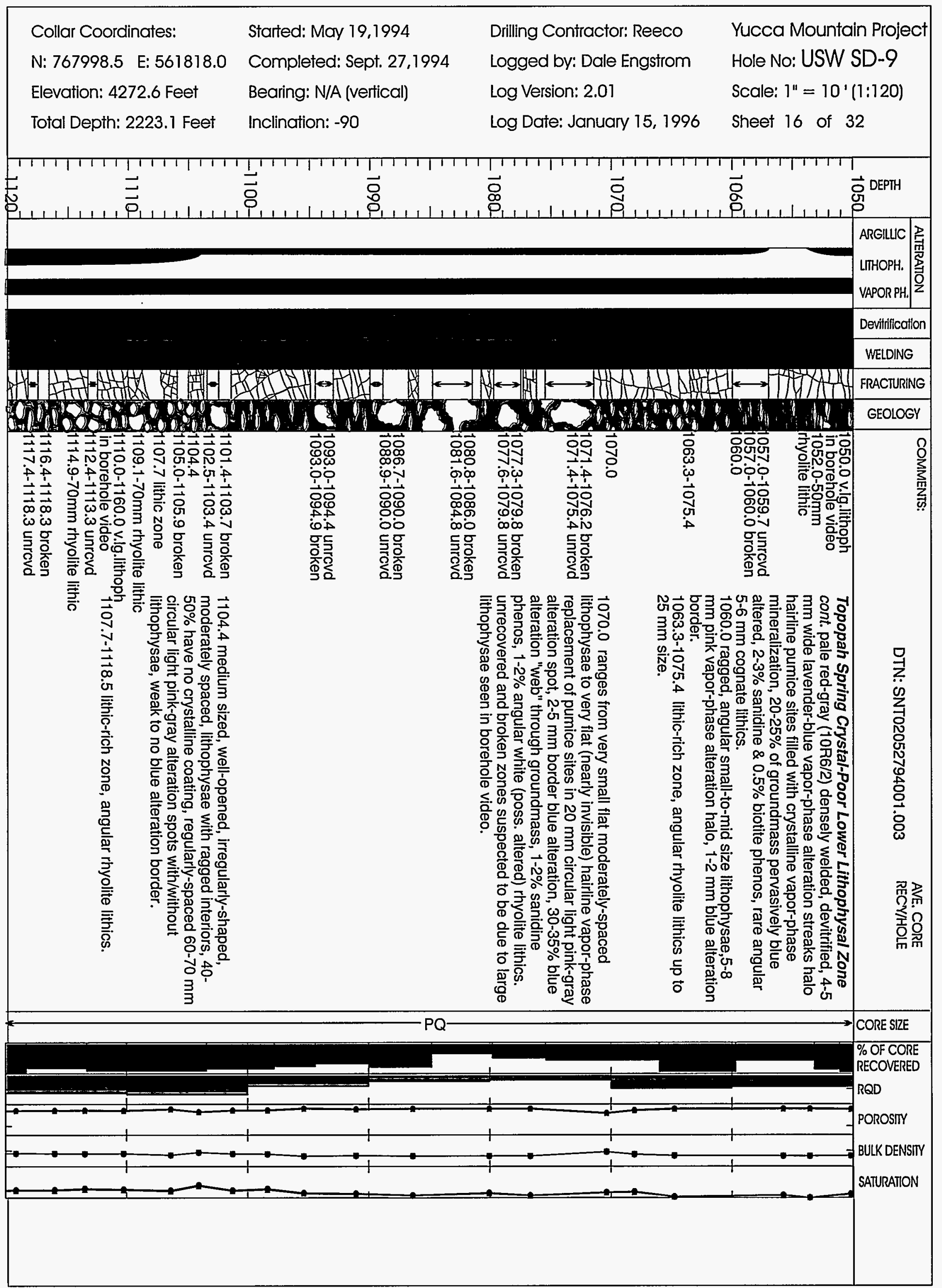




\section{Collar Coordinates:}

N: $767998.5 \quad$ E: 561818.0

Elevation: 4272.6 Feet

Total Depth: 2223.12 Feet
Started: May 19, 1994

Completed: Sept. 27، 1994

Bearing: N/A (vertical)

Inclination: -90
SANDIA NATIONAL LABS

Logged by: Dale Engstrom

Log Version: 2.01

Log Date: January 15, 1996
Yucca Mountain Project Hole No: USW SD-9

Scale: $1^{\prime \prime}=10^{\prime}(1: 120)$

Sheet 17 of 32

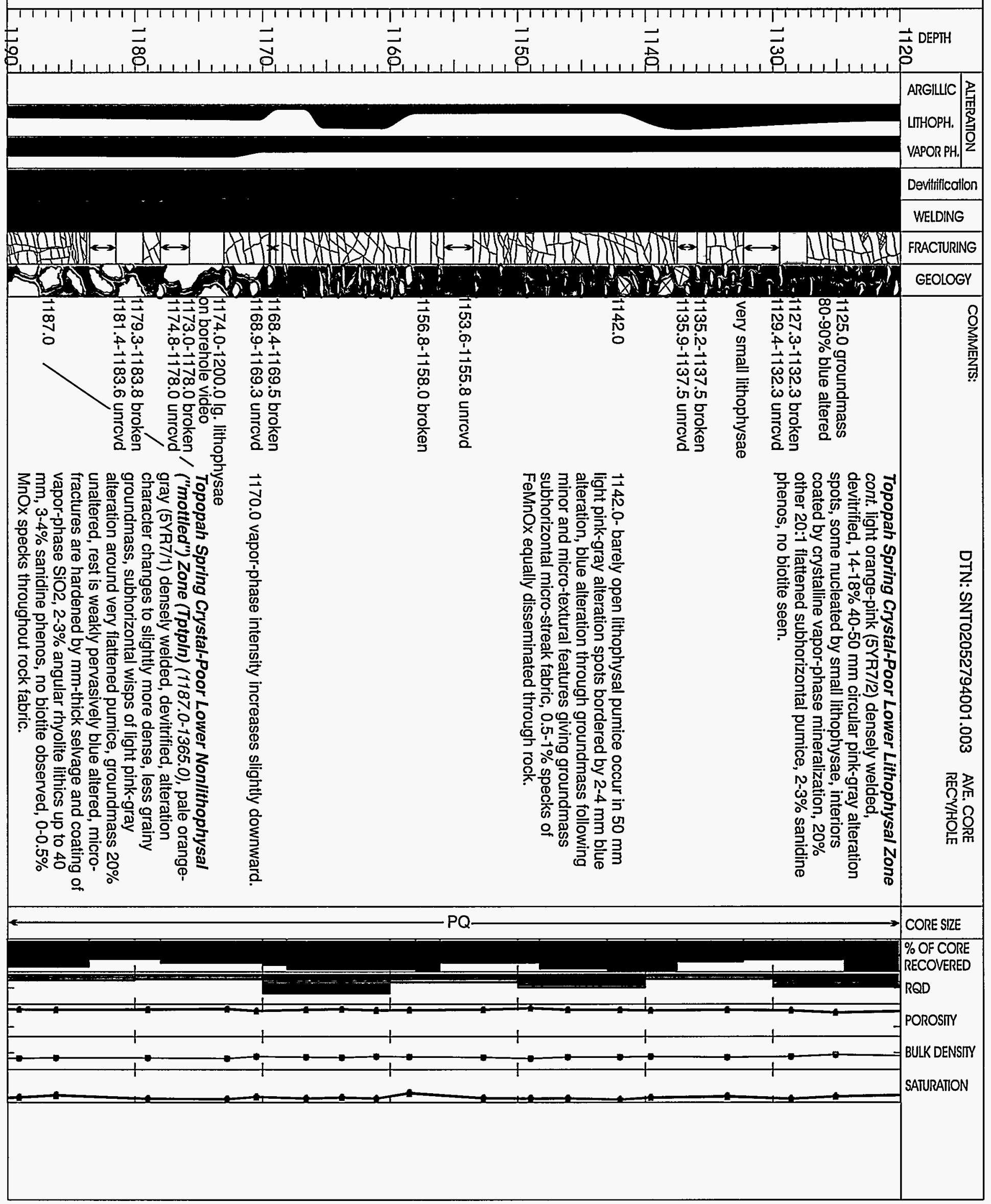




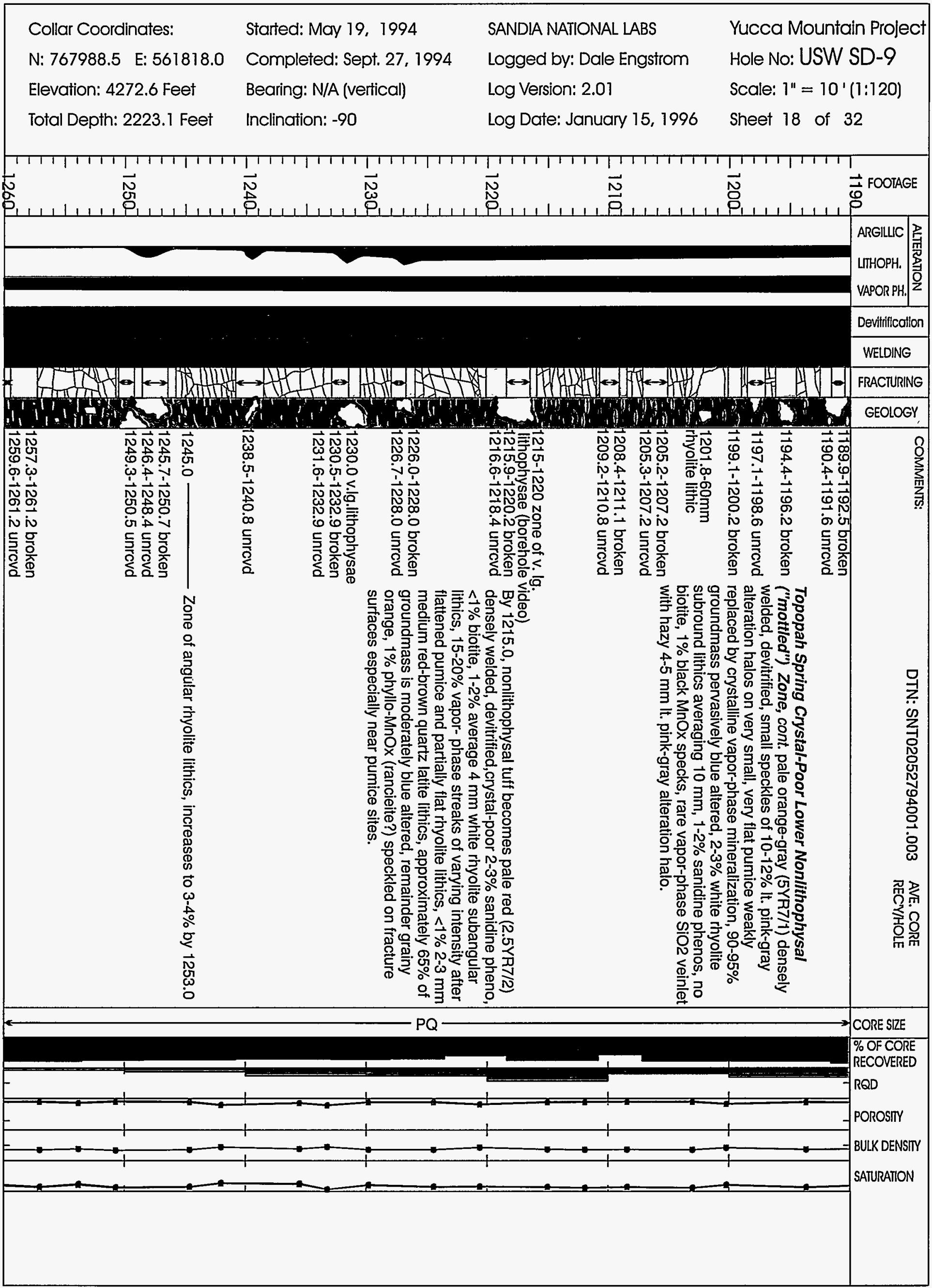




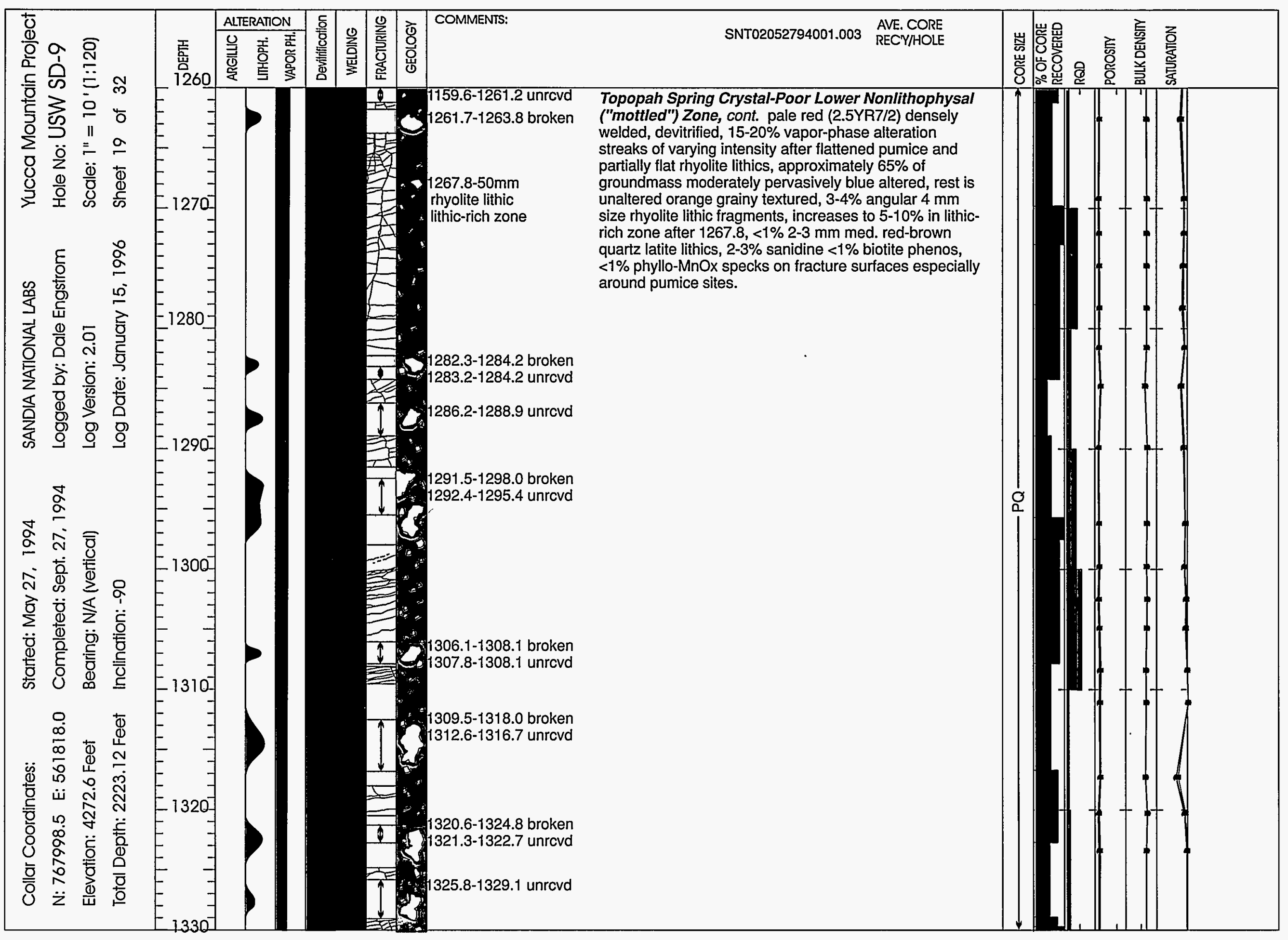


Collar Coordinates:

N: 767998.5 E: 561818.0

Elevation: 4272.6 Feet

Total Depth: 2223.1 Feet
Started: May 19, 1994

Completed: Sept. 27, 1994

Bearing: N/A (vertical)

Inclination: -90
SANDIA NATIONAL LABS

Logged by: Dale Engstrom

Log Version: 2.01

Log Date: January 15, 1996
Yucca Mountain Project Hole No: USW SD-9

Scale: $1^{\prime \prime}=10^{\prime}(1: 120)$

Sheet 20 of 32

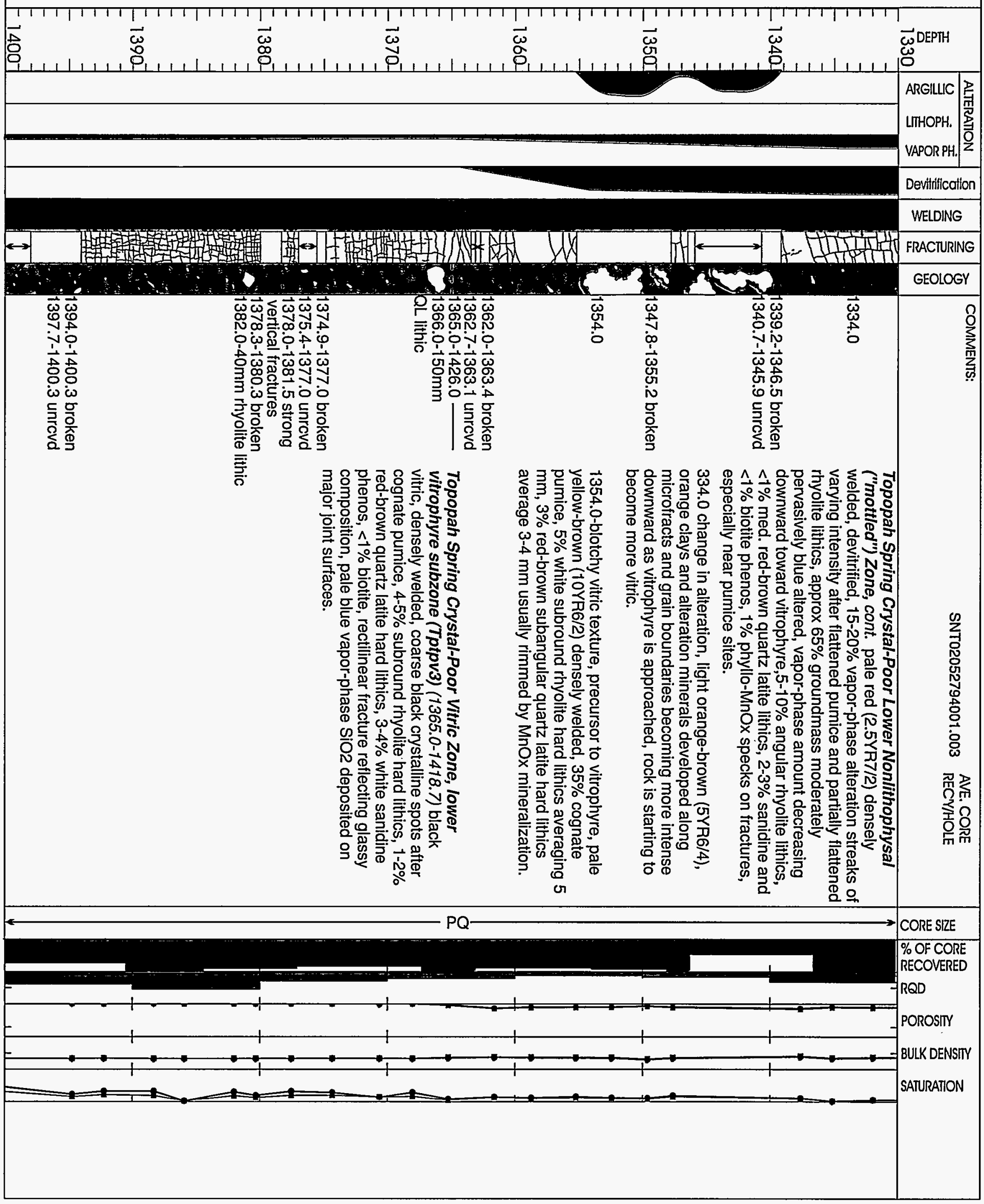


Collar Coordinates:

N: $767998.5 \quad$ E: 561818.0

Elevation: 4272.6 Feet

Total Depth: 2223.1 Feet
Started: May 19,1994

Completed: Sept. 27، 1994 Bearing: N/A (vertical) Inclination: -90
SANDIA NATIONAL LABS

Logged by: Dale Engstrom

Log Version: 2.01

Log Date: January 15, 1996
Yucca Mountain Project Hole No: USW SD-9

Scale: $1^{\prime \prime}=10^{\prime}(1: 120)$

Sheet 21 of 32

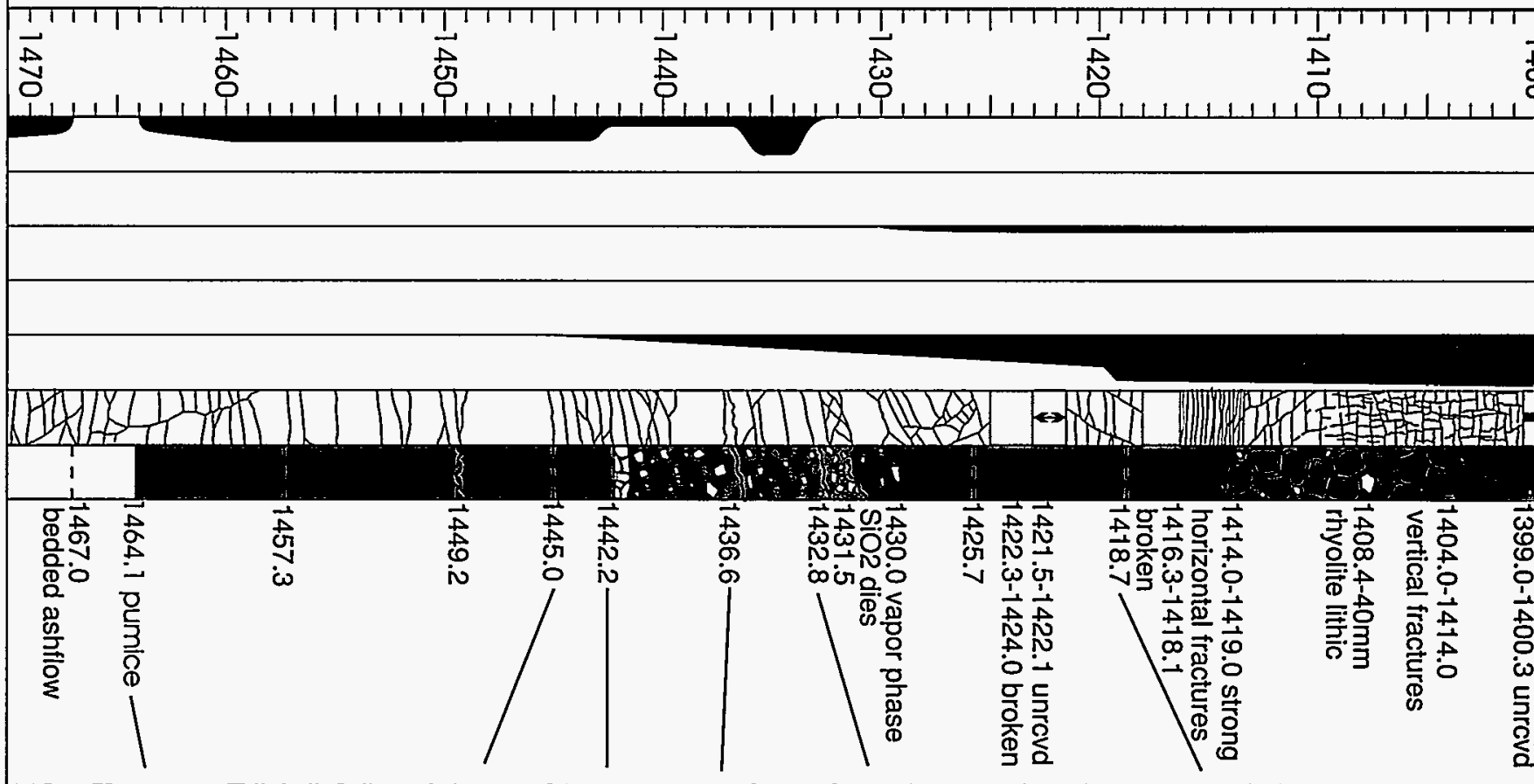

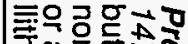

जิ을

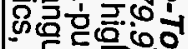

w

我亩

융ㅁํ용

용로용

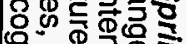

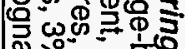

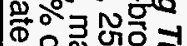

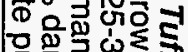

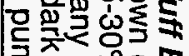

금ํำ

ధิ

灵음 꿍요

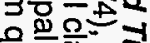

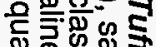

党

승으을엉

올음

요오요

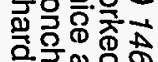

을용

으르루

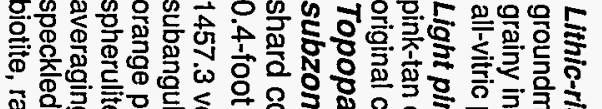

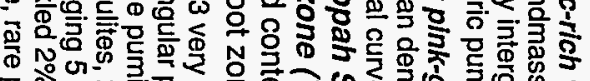

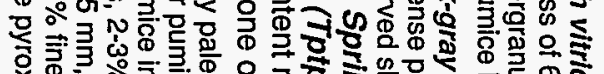

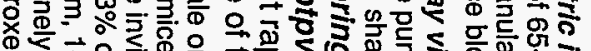

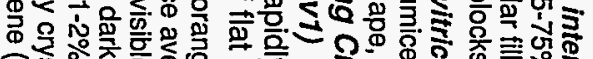

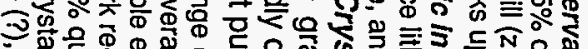

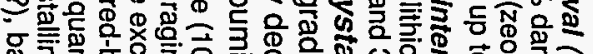

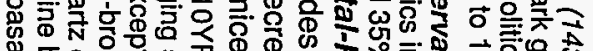

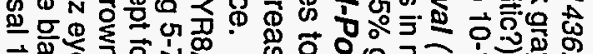

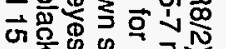

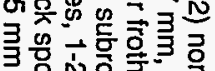

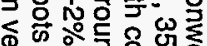

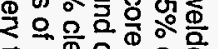

寻

象

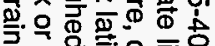

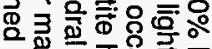

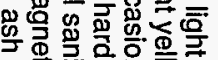

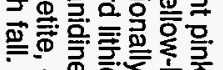

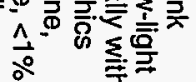

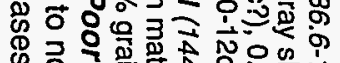

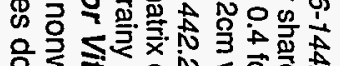

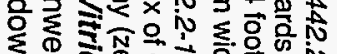

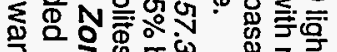

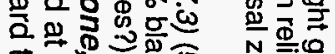

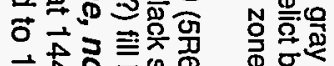

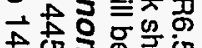

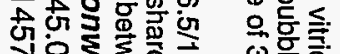

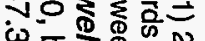

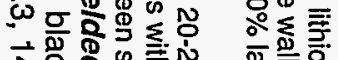

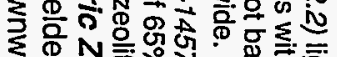

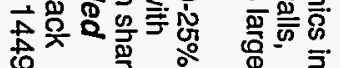

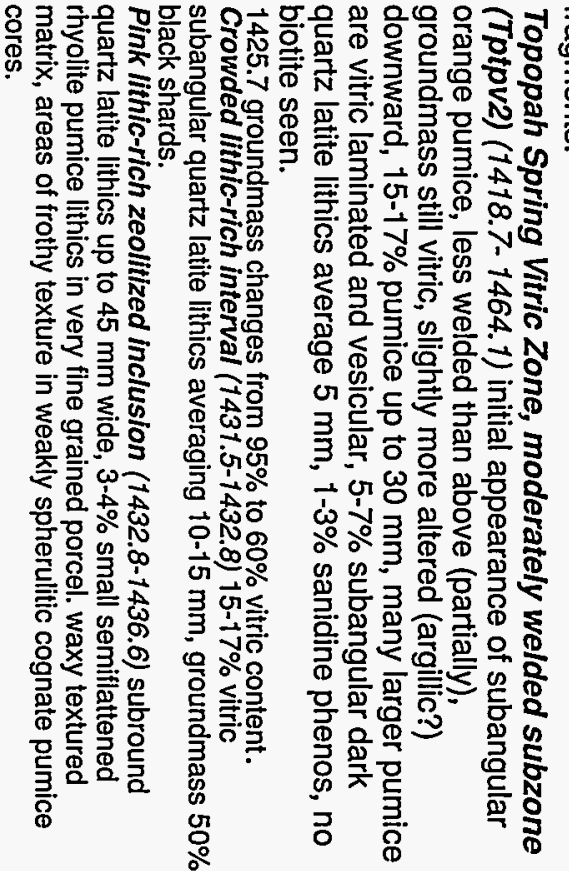

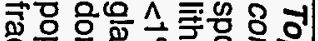

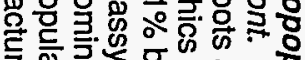
要要 8 त长 우믕응 웡 응

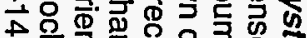

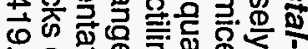
으응유

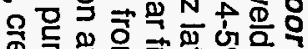

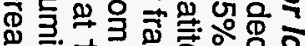

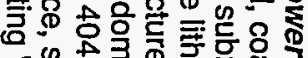
=年웅.

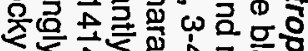

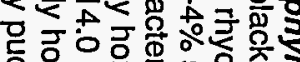
웃을.

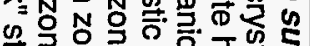

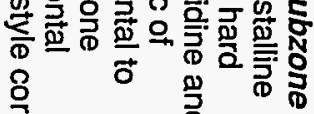
응 믈

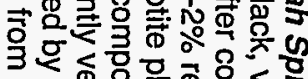

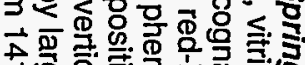

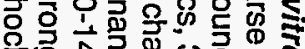

DEPTH ZEOLITIC LTTHOPH. VAPOR PH. Devitifificallon WELDING GEOLOGY i

$P Q$

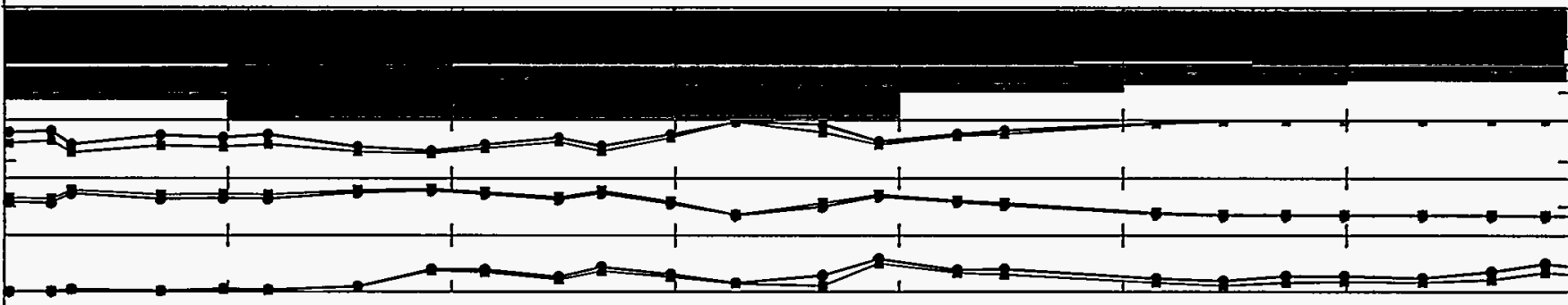

CORE SIZE

$\%$ OF CORE RECOVERED RQD 


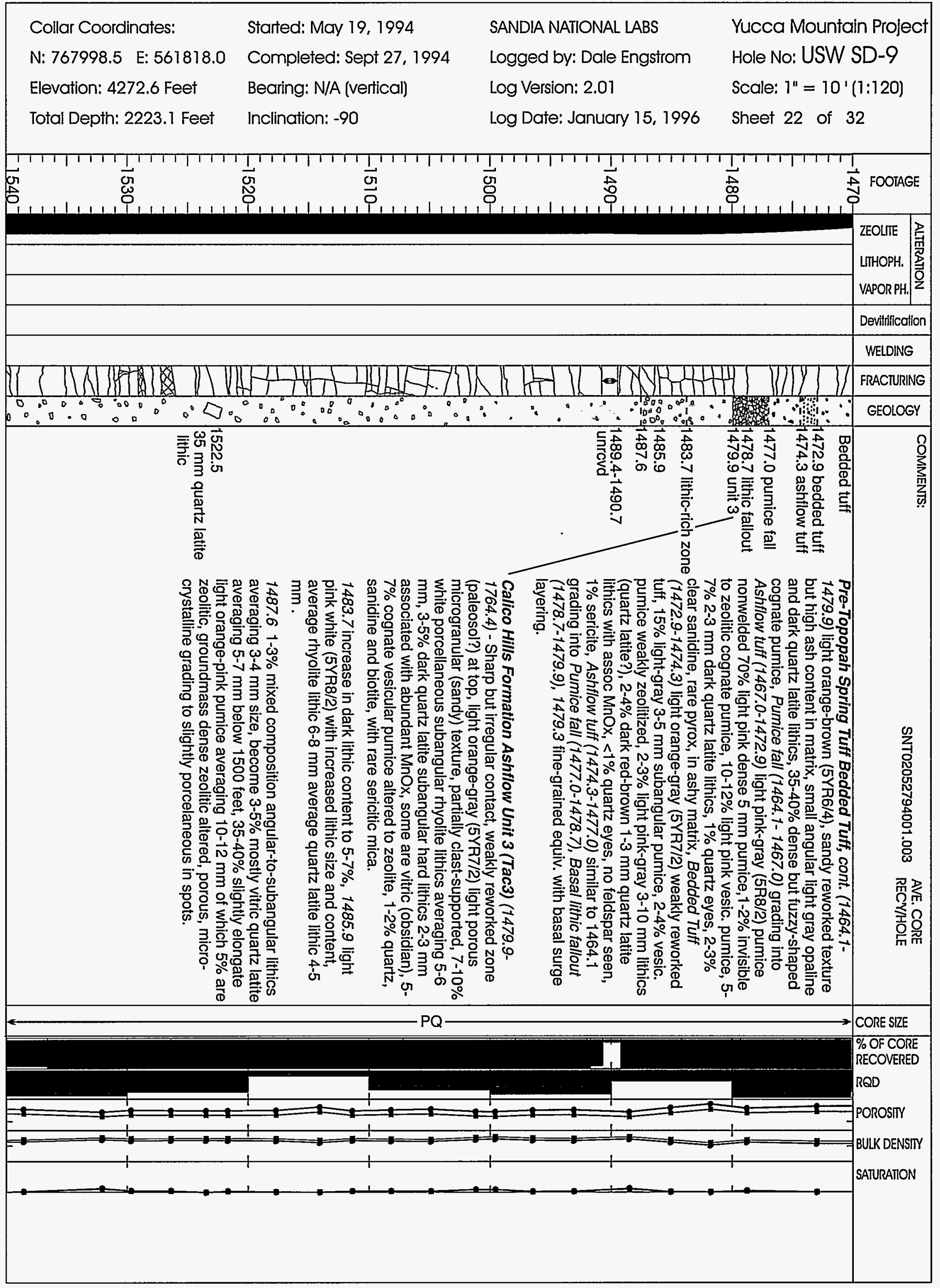


Collar Coordinates:

N: 767998.5 E: 561818.0

Elevation: 4272.6 Feet

Total Depth: 2223.12 Feet Inclination: -90
Started: May 19, 1994

Completed: Sept. 27, 1994 Bearing: N/A (vertical)
SANDIA NATIONAL LABS

Logged by: Dale Engstrom

Log Version: 2.01

Log Date: January 15, 1996
Yucca Mountain Project Hole No: USW SD-9

Scale: $1 "=10^{\prime}(1: 120)$ Sheet 23 of 32

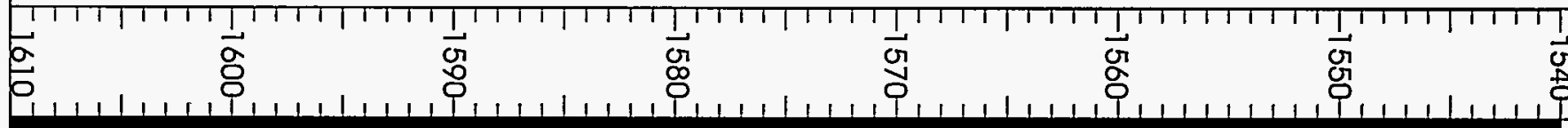

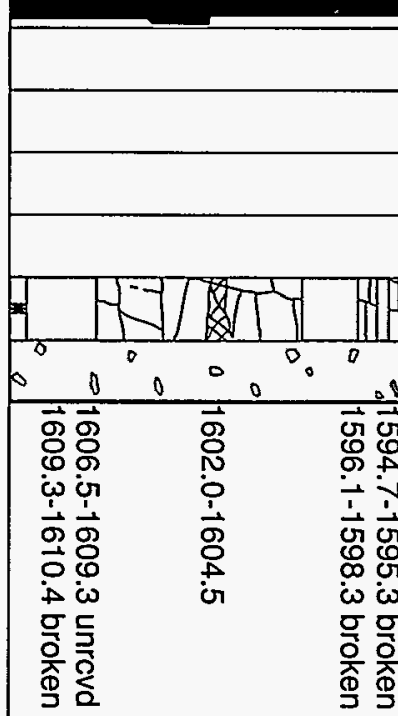

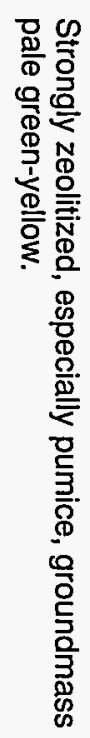

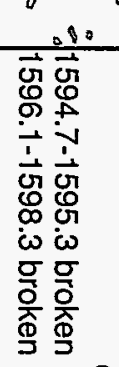

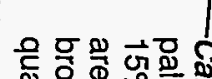

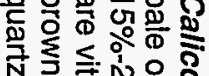

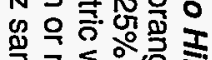

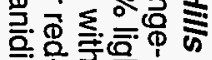
夏ㅇํㅇ

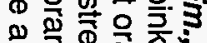

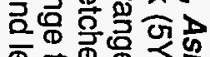

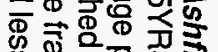

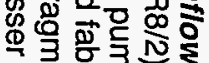

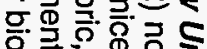

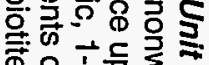

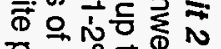

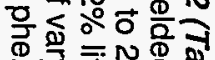

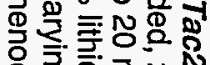

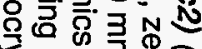
옹ㅇำ 8 을

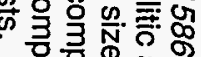
尊:

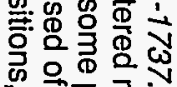

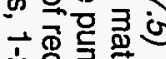

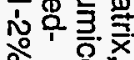
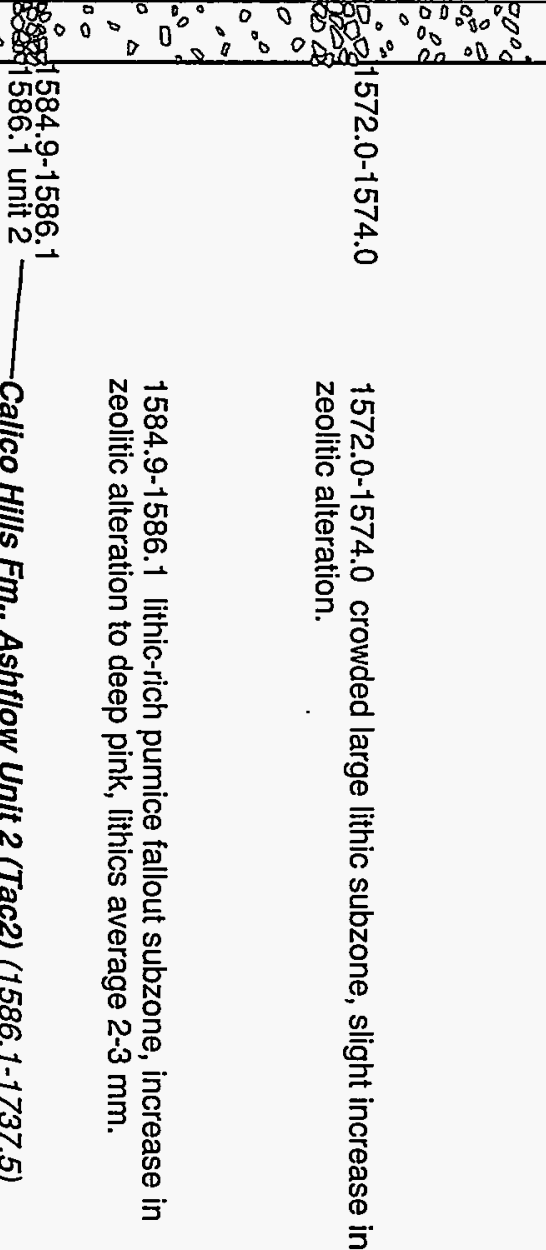
$00 \div$

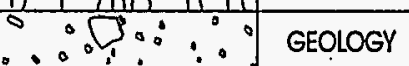

\begin{tabular}{|c|c|}
\hline$\%$ & \\
\hline 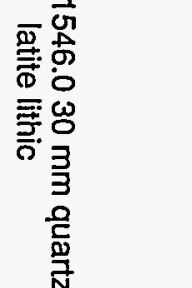 & $\begin{array}{l}8 \\
3 \\
3 \\
\text { 预 }\end{array}$ \\
\hline
\end{tabular}

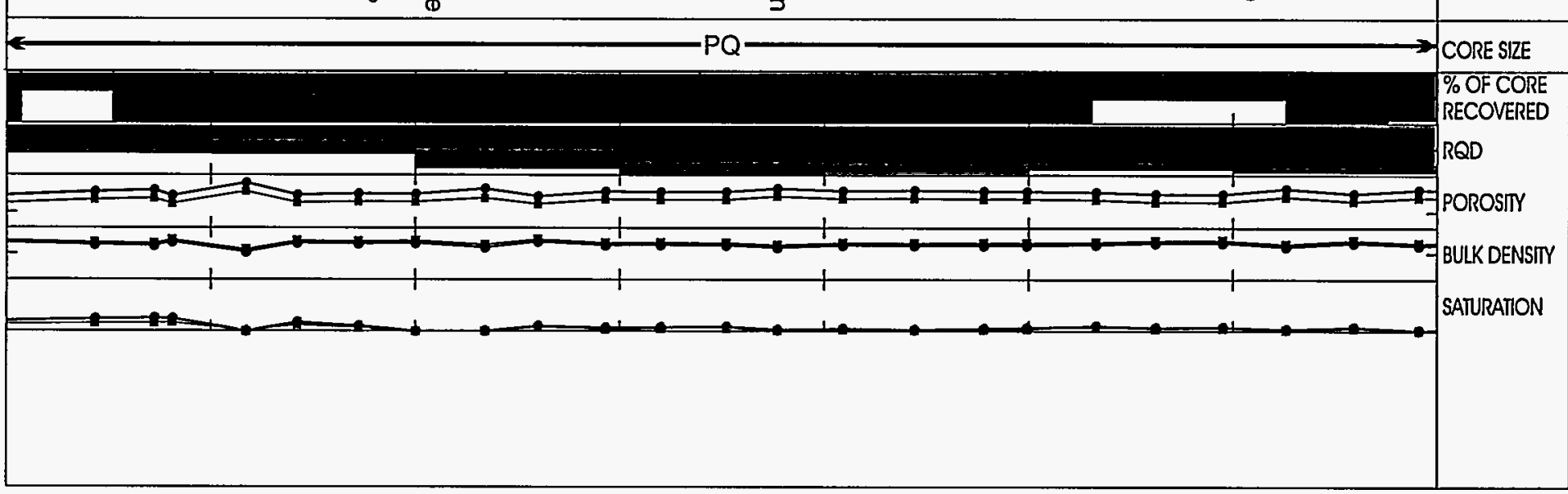


Collar Coordinates:

$\mathrm{N}: 767998.5$

E: 561818.0

Elevation: 4272.6 Feet

Total Depth: 2223.1 Feet
Started: Mat 19, 1994

Completed: Sept. 27, 1994 Bearing: N/A (vertical)

Inclination: -90
SANDIA NATIONAL LABS

Logged by: Dale Engstrom

Log Version: 2.01

Log Date: January 15, 1996
Yucca Mountain Project Hole No: USW SD-9

Scale: $1 "=10^{\prime}(1: 120)$

Sheet 24 of 32

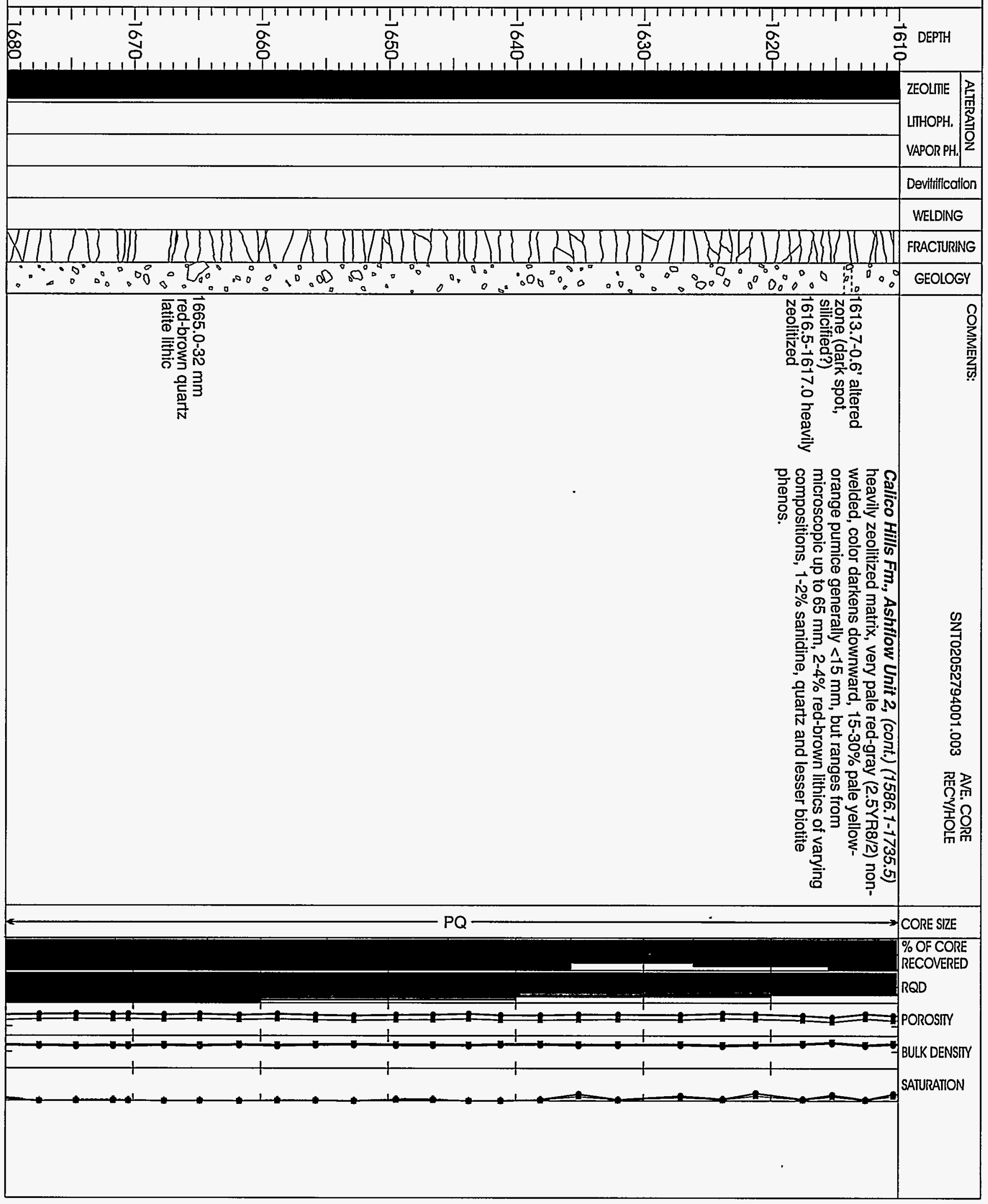




\section{Collar Coordinates:}

N: 767998.5

E: 561818.0

Elevation: 4272.6 Feet

Total Depth: 2223.1 Feet
Started: May 19, 1994

Completed: Sept. 27, 1994 Bearing: N/A (vertical)

Inclination: -90
SANDIA NATIONAL LABS

Logged by: Dale Engstrom

Log Version: 2.01

Log Date: January 15, 1996
Yucca Mountain Project Hole No: USW SD-9

Scale: $1 "=10^{\prime}(1: 120)$ Sheet 25 of 32

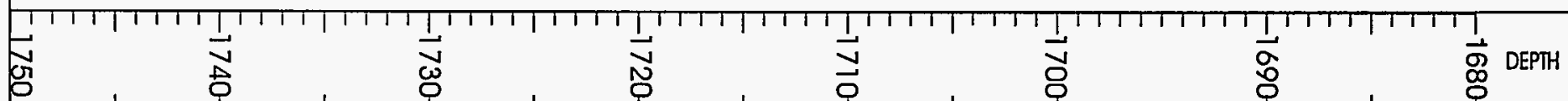

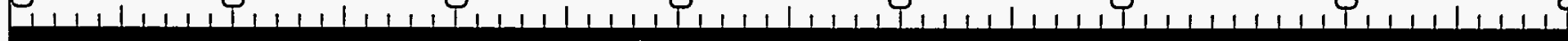

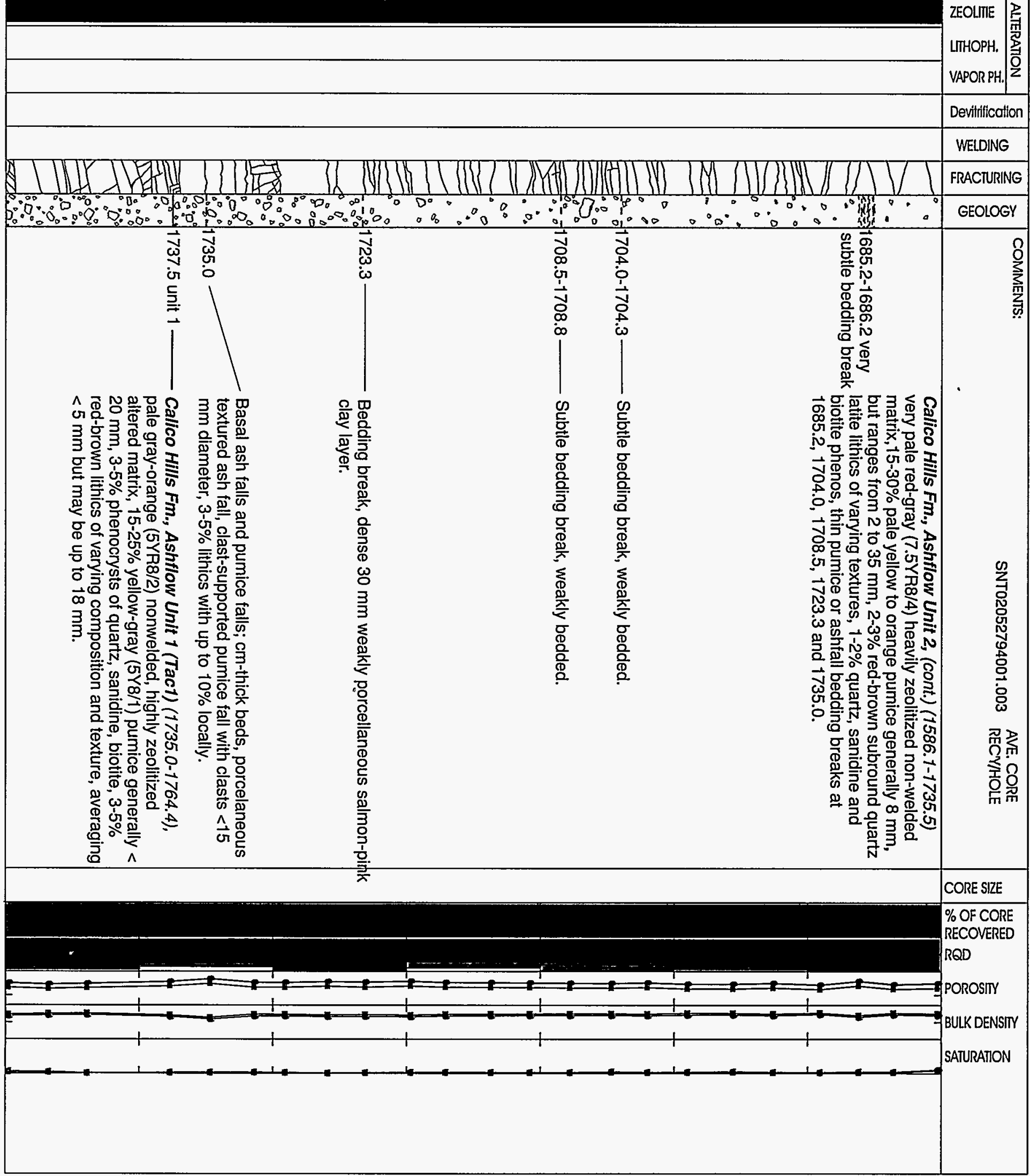


Collar Coordinates:

N: 767998.5

Elevation: 4272.6 Feet

Total Depth: 2223.1 Feet
Started: May 19, 1994

Completed: Sept. 27, 1994 Bearing: N/A (vertical) Inclination: -90
SANDIA NATIONAL LABS

Logged by: Dale Engstrom

Log Version: 2.01

Log Date: January 15, 1996
Yucca Mountain Project Hole No: USW SD-9

Scale: $1 "=10^{\prime}(1: 120)$

Sheet 27 of 32

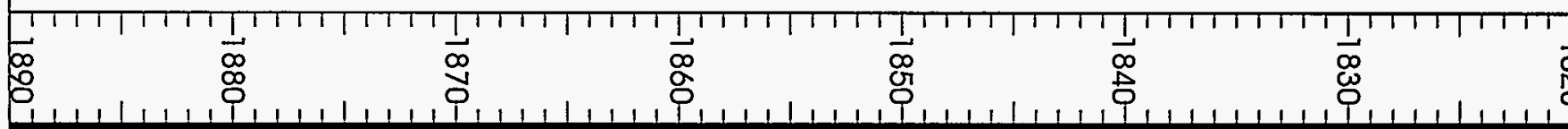

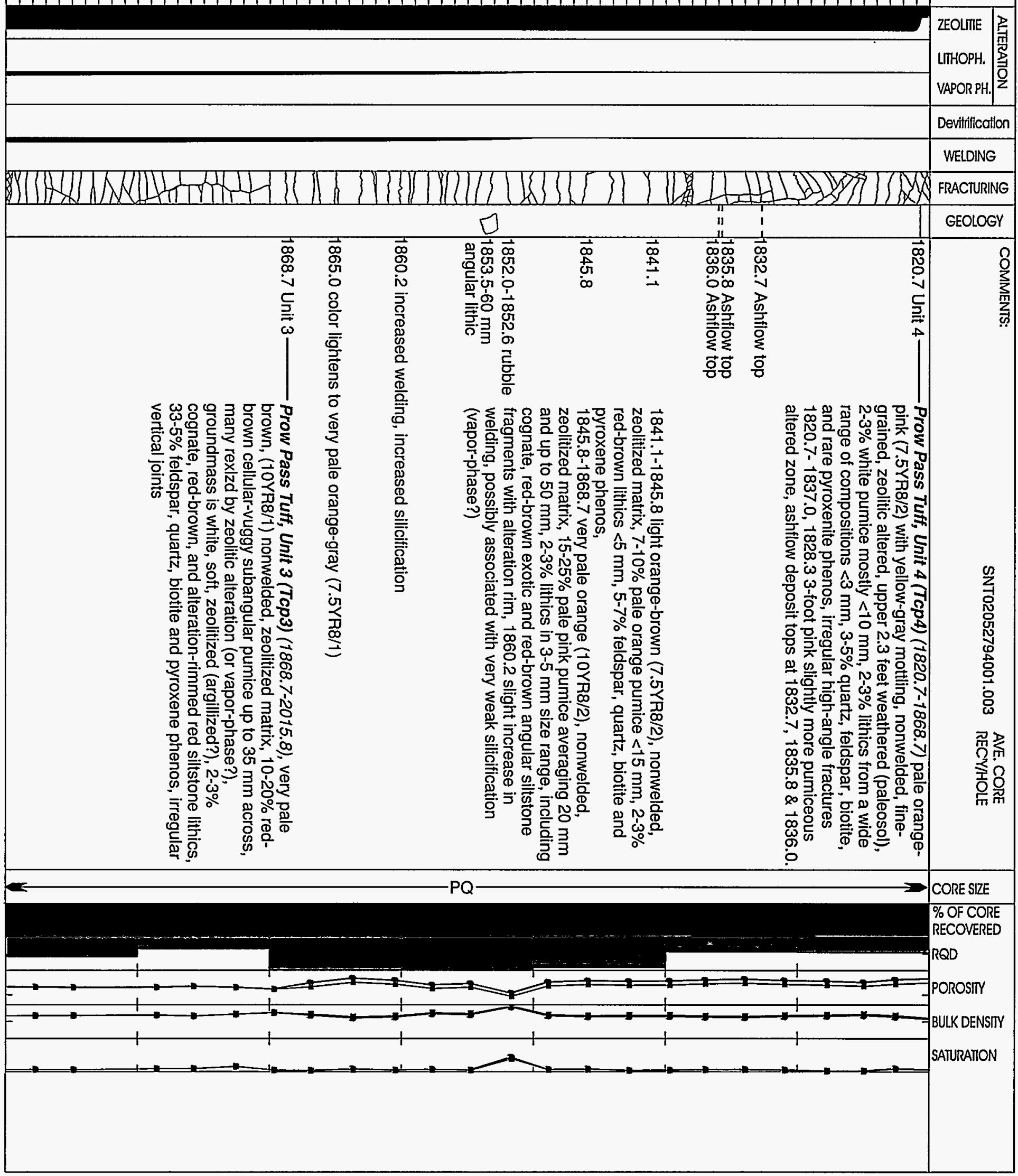


Collar Coordinates:

N: 767998.5 E: 561818.0

Elevation: 4272.6 Feet

Total Depth: 2223.1 Feet
Started: May 19, 1994

Completed: Sept. 27, 1994 Logged by: Dale Engstrom

Bearing: N/A (vertical)

Inclination: -90
SANDIA NATIONAL LABS

Log Version: 2.01

Log Date: January 15, 1996
Yucca Mountain Project Hole No: USW SD-9

Scale: $]^{\prime \prime}=10^{\prime}(1: 120)$

Sheet 28 of 32

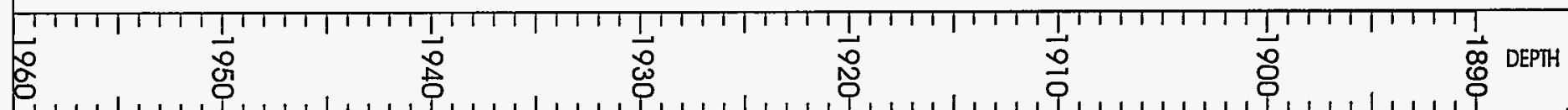

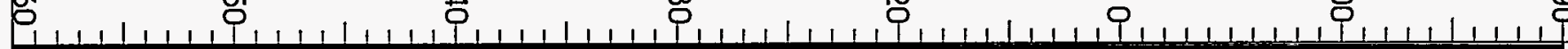

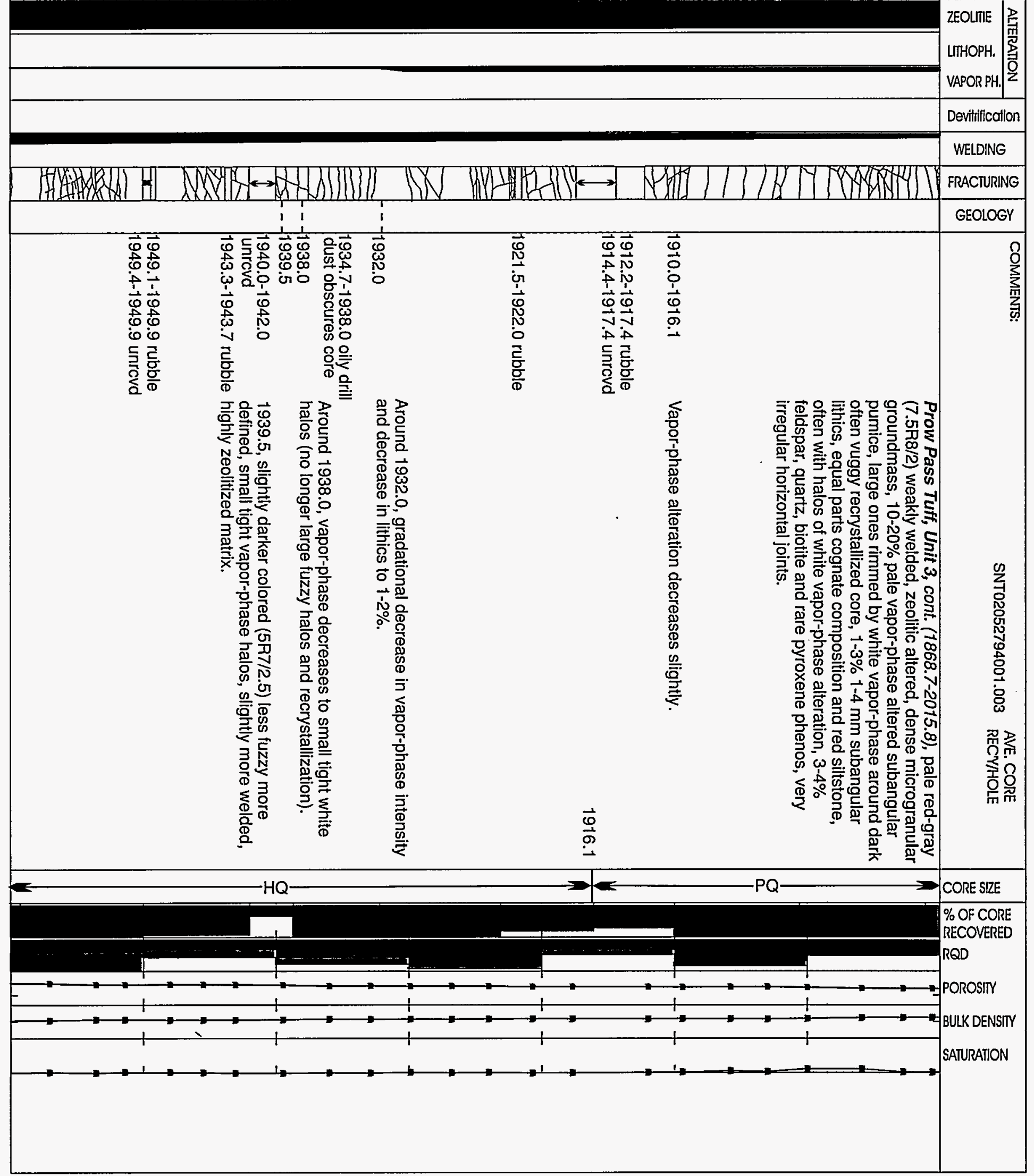




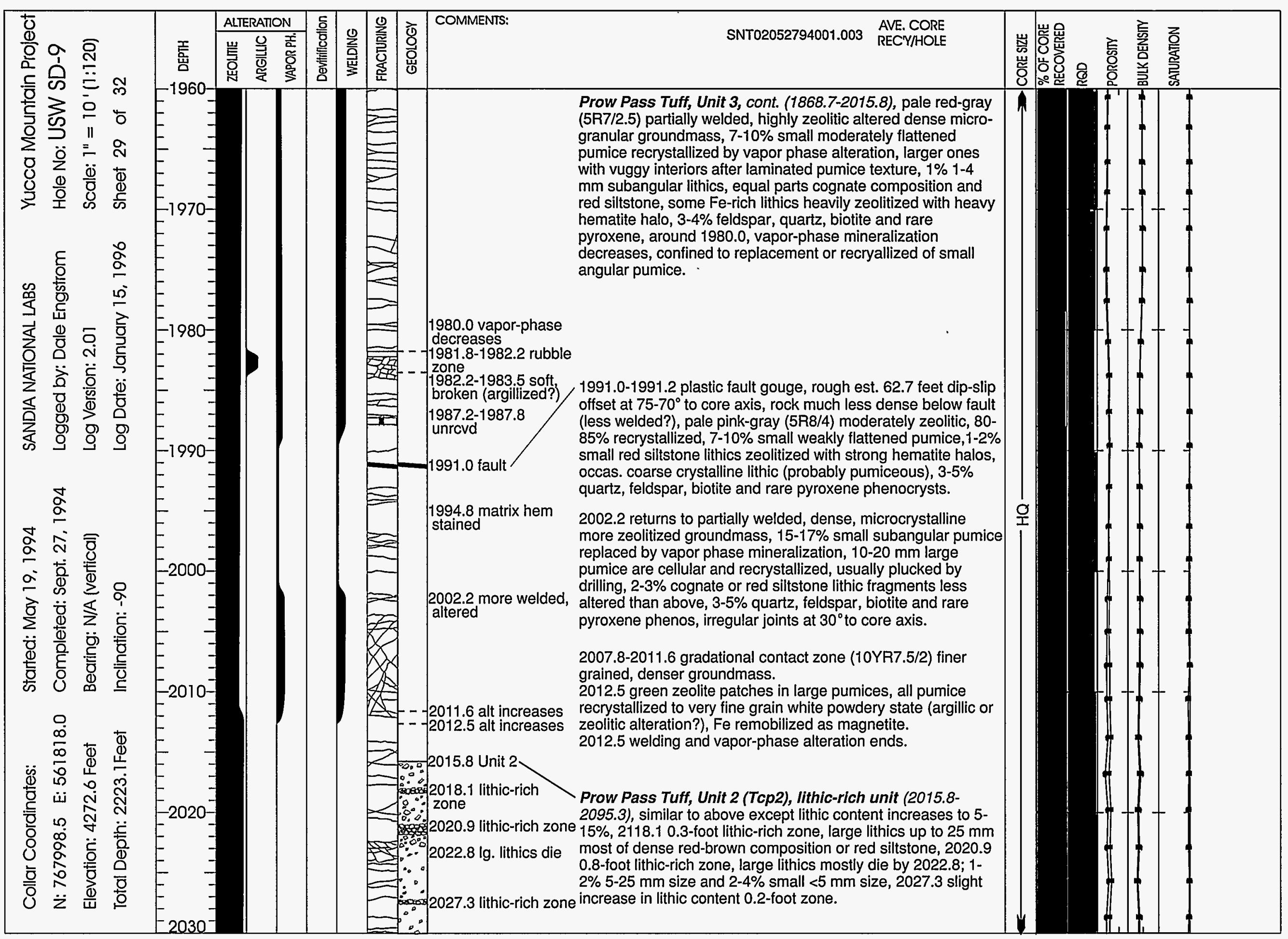


Collar Coordinates:

$\mathrm{N}: 767998.5$

E: 561818.0

Elevation: 4272.6 Feet

Total Depth: 2223.1 Feet
Started: May 19, 1994

Completed: Sept. 27, 1994 Bearing: N/A (vertical) Inclination: -90
SANDIA NATIONAL LABS

Logged by: Dale Engstrom

Log Version: 2.01

Log Date: January 15, 1996
Yucca Mountain Project Hole No: USW SD-9

Scale: $1^{\prime \prime}=10^{\prime}(1: 120)$

Sheet 30 of 32
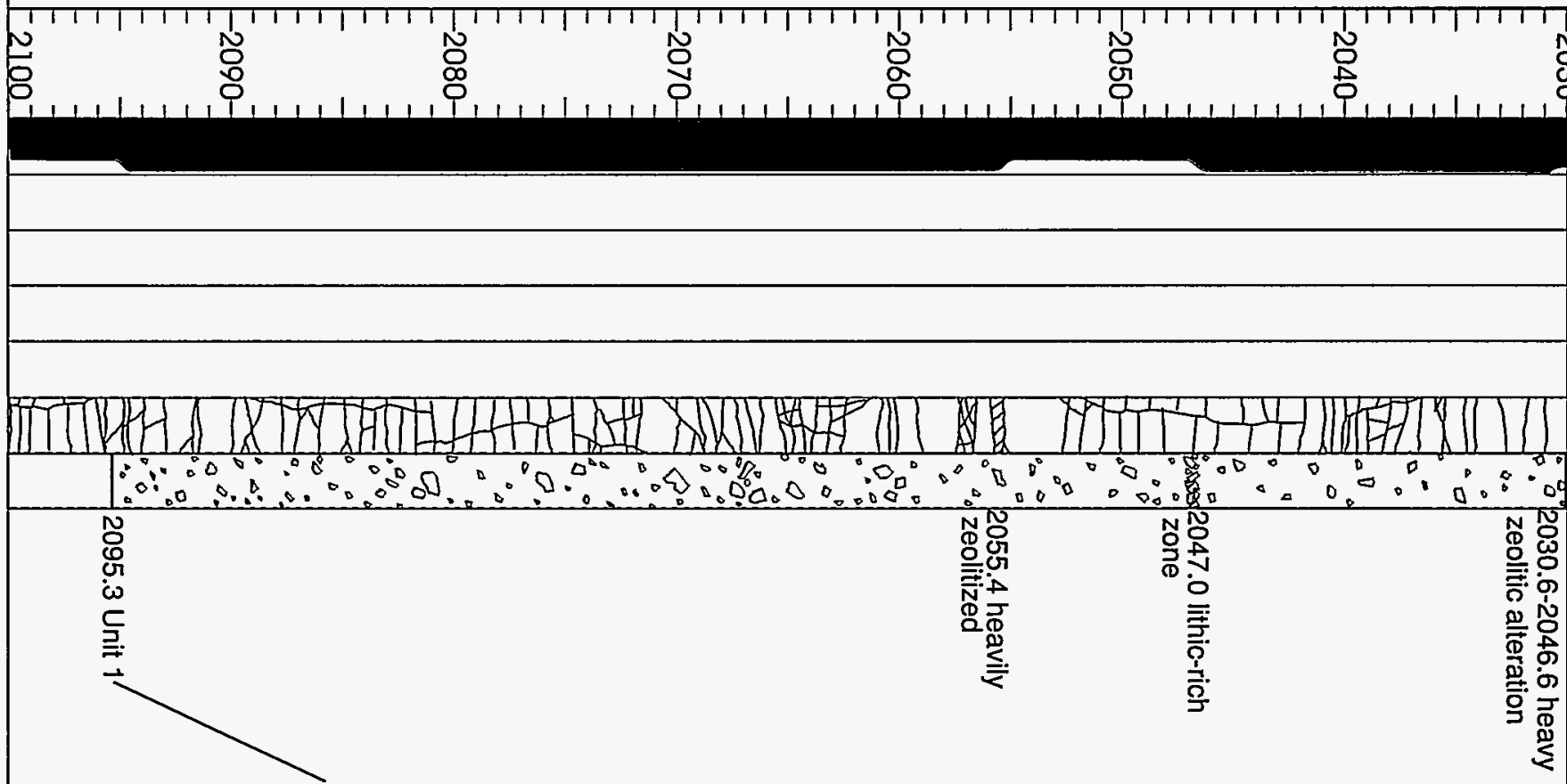

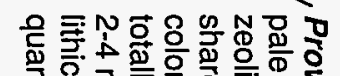

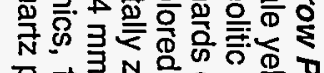

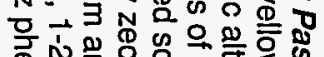

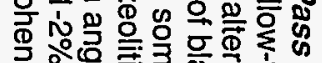

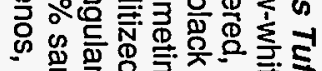

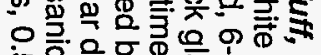

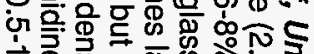

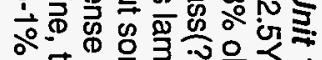

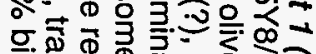

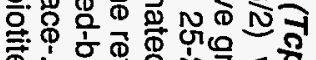

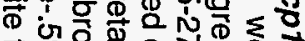

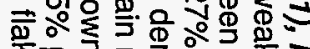

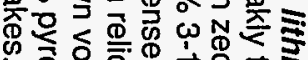

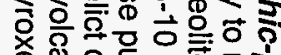

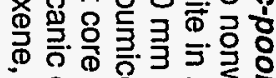

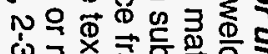

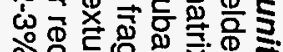

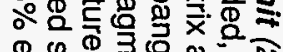

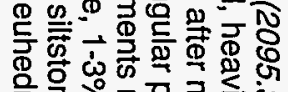

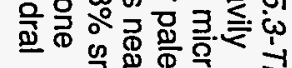

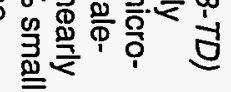

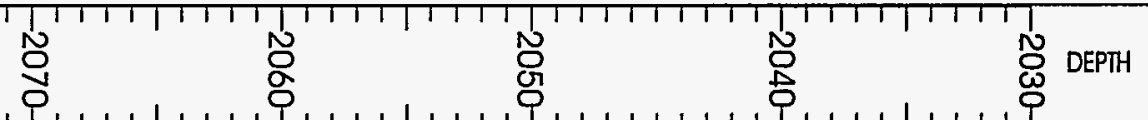
ZEOLTIE ARGILIC VAPOR PH. Devitifíication WELDING FRACTURING GEOLOGY

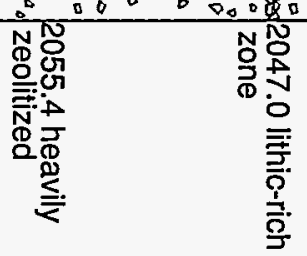

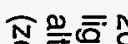

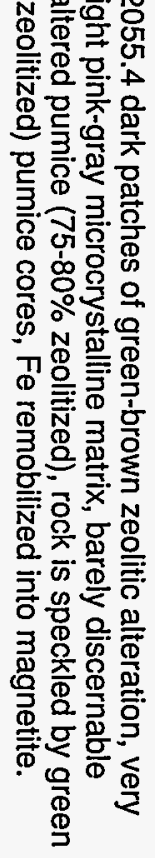

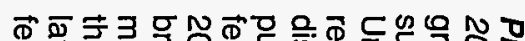

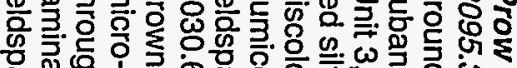

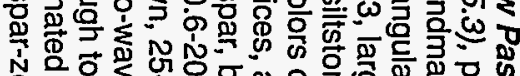

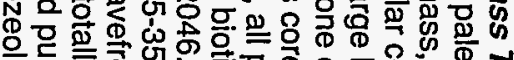

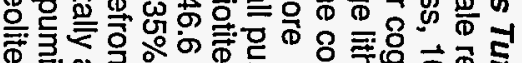

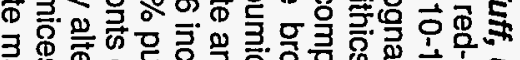

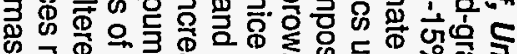
必

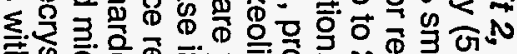

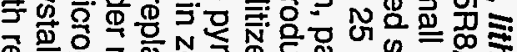

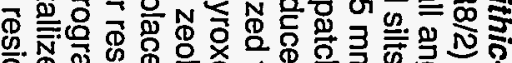

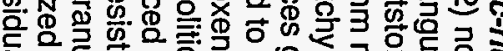

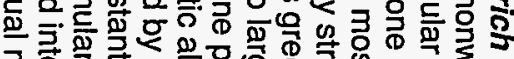

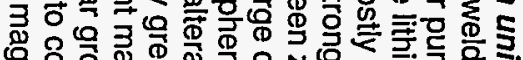

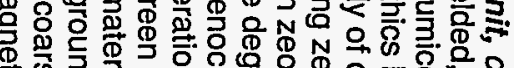
龸息 (

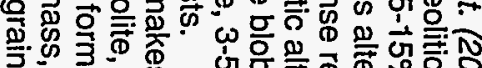

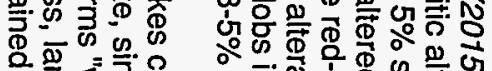

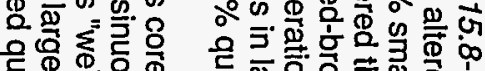

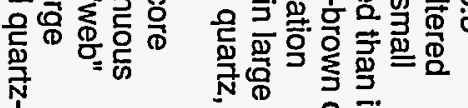

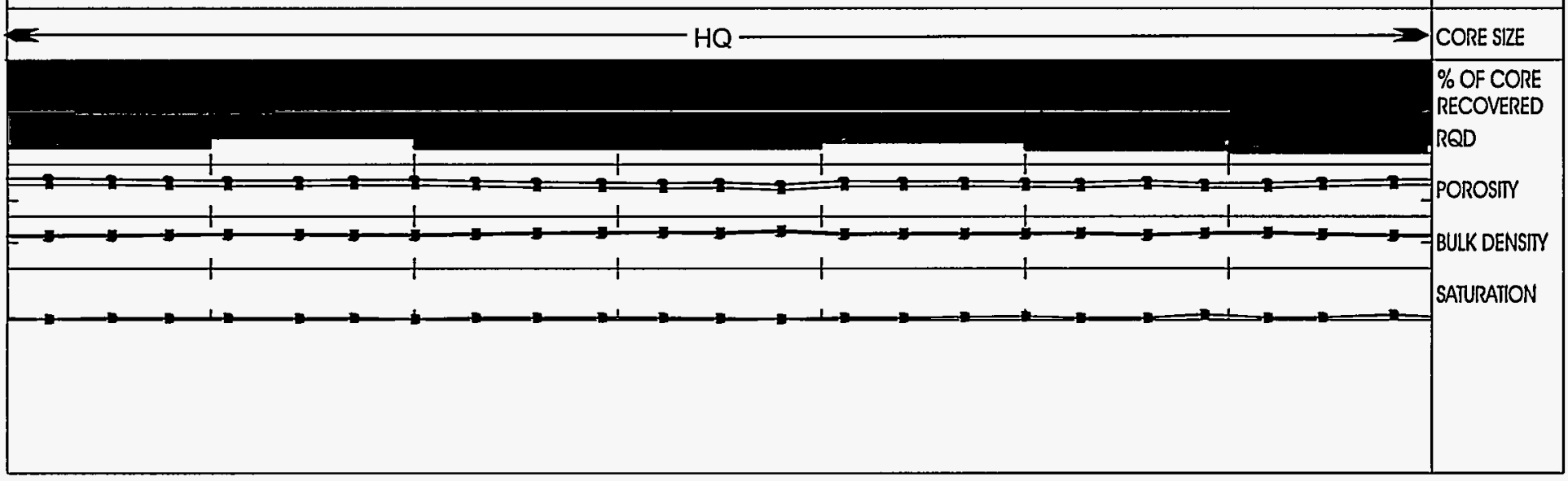


Collar Coordinates:

$\begin{array}{lll}N: & 767998.5 & \text { E: } 561818.0\end{array}$

Elevation: 4272.6 Feet

Total Depth: 2223.1 Feet
Started: May 19, 1994

Completed: Sept. 27, 1994

Bearing: N/A (vertical)

Inclination: -90
SANDIA NATIONAL LABS

Logged by: Dale Engstrom

Log Version: 2.01

Log Date: January 15, 1996
Yucca Mountain Project Hole No: USW SD-9

Scale: $7^{\prime \prime}=10^{\prime}(1: 120)$

Sheet 31 of 32

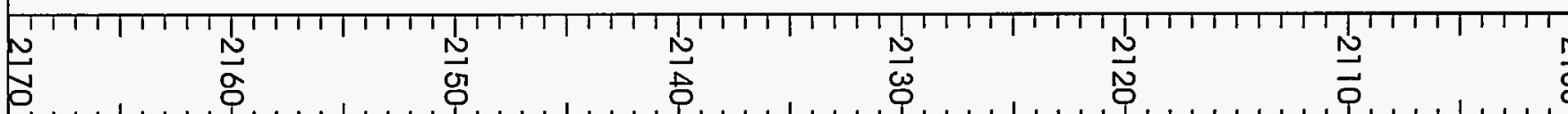

Pe

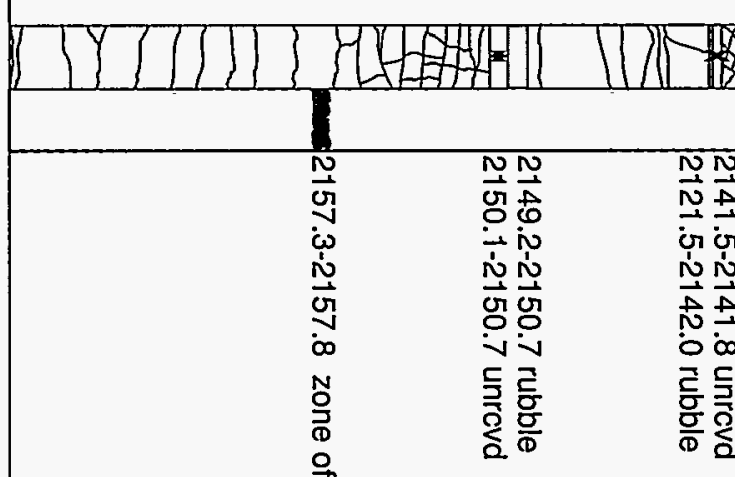

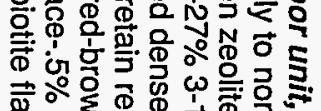

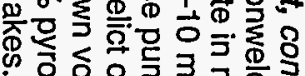

응으을

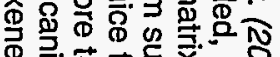

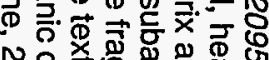

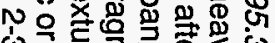

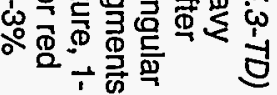

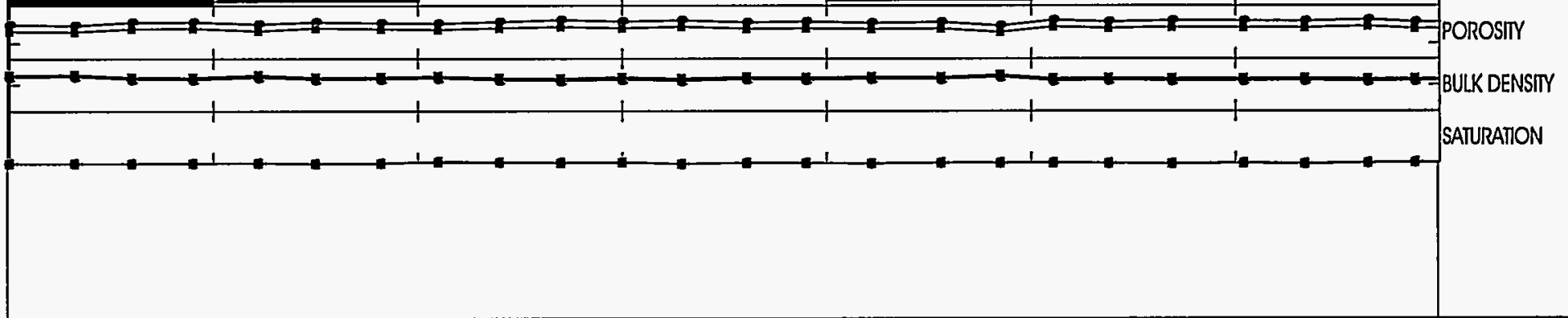




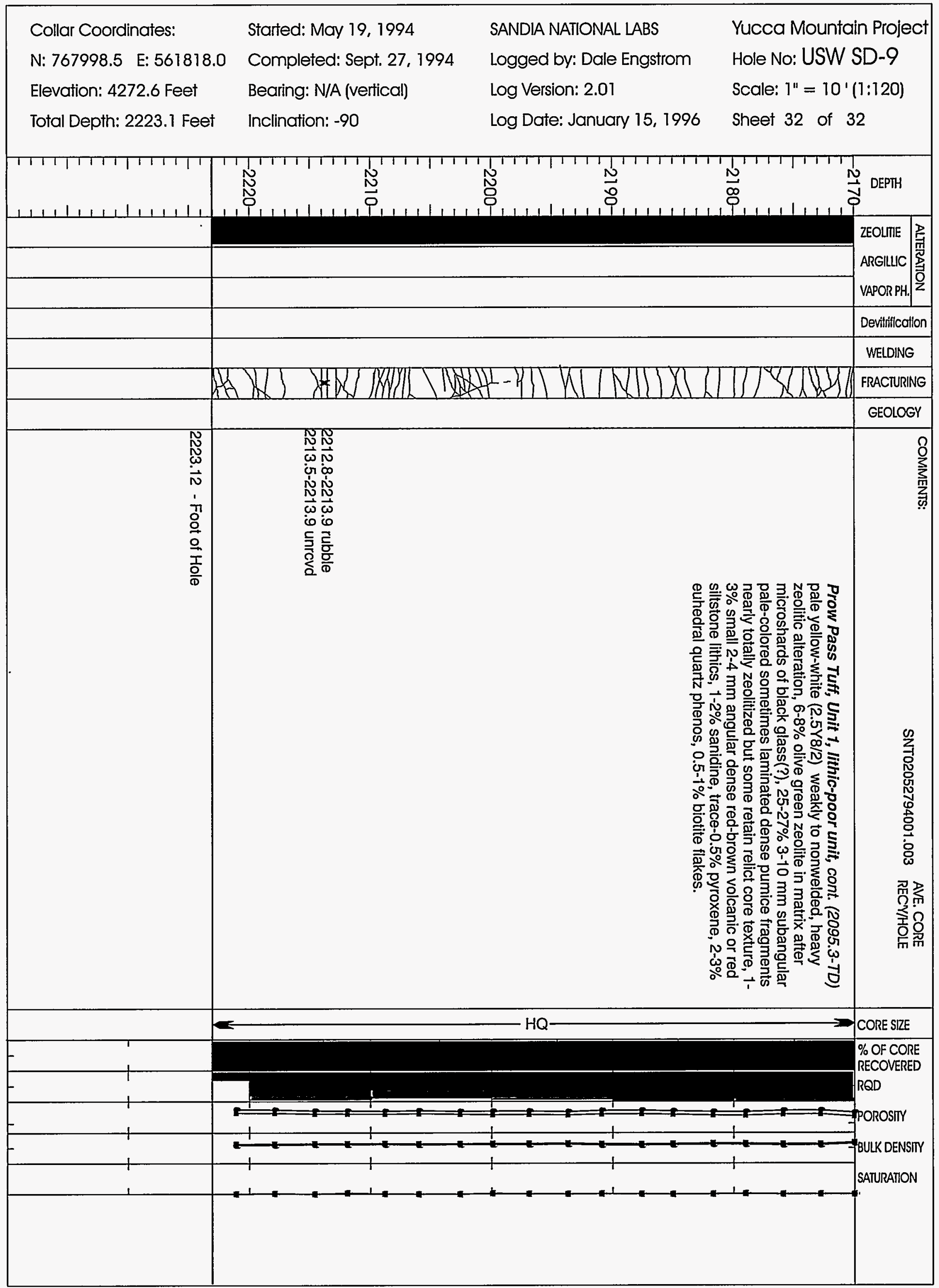




\section{Appendix C: Core Recovery Data}


Table C-1: Core Recovery Data

[Sources (Data-tracking numbers, DTNs): 1-TM0000000SD9RS.001; 2-TM0000000SD9RS.002; 3-TM0000000SD9RS.003; 4-TM0000000SD9RS.004]

\begin{tabular}{|c|c|c|c|c|c|c|}
\hline $\begin{array}{l}\text { Run } \\
\text { No. }\end{array}$ & $\begin{array}{c}\text { Interval } \\
\text { Bottom } \\
\text { (feet) }\end{array}$ & $\begin{array}{l}\text { Drilled } \\
\text { (feet) }\end{array}$ & $\begin{array}{l}\text { Recovered } \\
\text { (feet) }\end{array}$ & $\begin{array}{c}\text { Core } \\
\text { Recovery } \\
\text { (percent) }\end{array}$ & Source & $\begin{array}{c}\text { Page } \\
\text { No. }\end{array}$ \\
\hline 0 & 53.6 & -- & - & -- & 1 & 1 \\
\hline 1 & 63.1 & 9.5 & 9.3 & 98 & 1 & 2 \\
\hline 2 & 72.9 & 9.8 & 9.8 & 100 & 1 & 4 \\
\hline 3 & 82.4 & 9.5 & 9.3 & 98 & 1 & 6 \\
\hline 4 & 92.1 & 9.7 & 9.3 & 96 & 1 & 7 \\
\hline 5 & 102.0 & 9.9 & 9.9 & 100 & 1 & 8 \\
\hline 6 & 111.8 & 9.8 & 9.8 & 100 & 1 & 9 \\
\hline 7 & 121.7 & 9.9 & 9.8 & 99 & 1 & 11 \\
\hline 8 & 131.5 & 9.8 & 4.3 & 44 & 1 & 12 \\
\hline 9 & 141.3 & 9.8 & 9.5 & 97 & 1 & 13 \\
\hline 10 & 151.1 & 9.8 & 2.7 & 28 & 1 & 13 \\
\hline 11 & 159.4 & 8.3 & 8.3 & 100 & 1 & 14 \\
\hline 12 & 16.09 & 9.6 & 6.8 & 71 & 1 & 15 \\
\hline 13 & 176.0 & 7.0 & 5.6 & 80 & 1 & 16 \\
\hline 14 & 185.3 & 9.3 & 1.7 & 18 & 1 & 16 \\
\hline 15 & 191.2 & 5.9 & 5.1 & 86 & 1 & 17 \\
\hline 16 & 199.2 & 8.0 & 0.0 & 0 & 1 & 17 \\
\hline 17 & 208.5 & 9.3 & 0.0 & 0 & 1 & 18 \\
\hline 18 & 218.5 & 10.0 & 10.0 & 100 & 1 & 19 \\
\hline 19 & 227.8 & 9.3 & 8.3 & 89 & 1 & 19 \\
\hline 20 & 237.7 & 9.9 & 9.0 & 91 & 1 & 20 \\
\hline 21 & 244.6 & 6.9 & 6.9 & 100 & 1 & 21 \\
\hline 22 & 254.1 & 9.5 & 9.4 & 99 & 1 & 22 \\
\hline 23 & 263.8 & 9.7 & 9.7 & 100 & 1 & 22 \\
\hline 24 & 270.0 & 6.2 & 6.0 & 97 & 1 & 23 \\
\hline 25 & 275.8 & 5.8 & 3.5 & 60 & 1 & 24 \\
\hline 26 & 281.8 & 6.0 & 5.3 & 88 & 1 & 26 \\
\hline 27 & 290.2 & 8.4 & 8.0 & 95 & 1 & 29 \\
\hline 28 & 297.2 & 7.0 & 3.2 & 46 & 1 & 30 \\
\hline 29 & 302.8 & 5.6 & 4.3 & 77 & 1 & 31 \\
\hline 30 & 305.5 & 2.7 & 0.9 & 33 & 1 & 31 \\
\hline
\end{tabular}

Table C-1: Core Recovery Data (Continued)

[Sources (Data-tracking numbers, DTNs): 1-TM0000000SD9RS.001;

2-TM0000000SD9RS.002; 3-TM0000000SD9RS.003; 4-TM0000000SD9RS.004]

\begin{tabular}{ccccccc}
\hline $\begin{array}{c}\text { Run } \\
\text { No. }\end{array}$ & $\begin{array}{c}\text { Interval } \\
\text { Bottom } \\
\text { (feet) }\end{array}$ & $\begin{array}{c}\text { Drllled } \\
\text { (feet) }\end{array}$ & $\begin{array}{c}\text { Recovered } \\
\text { (feet) }\end{array}$ & $\begin{array}{c}\text { Core } \\
\text { Recovery } \\
\text { (percent) }\end{array}$ & Source & $\begin{array}{c}\text { Page } \\
\text { No. }\end{array}$ \\
\hline 31 & 311.5 & 6.0 & 6.0 & 100 & 1 & 32 \\
32 & 320.7 & 9.2 & 7.4 & 80 & 1 & 33 \\
33 & 330.3 & 9.6 & 9.5 & 99 & 1 & 34 \\
34 & 337.4 & 7.1 & 6.2 & 87 & 1 & 35 \\
35 & 347.2 & 9.8 & 9.2 & 94 & 1 & 36 \\
36 & 356.5 & 9.3 & 6.7 & 72 & 1 & 38 \\
37 & 361.3 & 4.8 & 3.3 & 69 & 1 & 39 \\
38 & 368.1 & 6.8 & 4.1 & 60 & 1 & 41 \\
39 & 375.6 & 7.5 & 4.3 & 57 & 1 & 42 \\
40 & 384.9 & 9.3 & 8.0 & 86 & 1 & 44 \\
41 & 393.4 & 8.5 & 4.5 & 53 & 1 & 45 \\
42 & 402.3 & 8.9 & 8.5 & 96 & 1 & 46 \\
43 & 409.5 & 7.2 & 6.7 & 93 & 1 & 47 \\
44 & 419.0 & 9.5 & 7.4 & 78 & 1 & 47 \\
45 & 428.6 & 9.6 & 8.7 & 91 & 1 & 47 \\
46 & 435.9 & 7.3 & 6.4 & 88 & 1 & 48 \\
47 & 445.1 & 9.2 & 5.6 & 61 & 1 & 49 \\
48 & 450.5 & 5.4 & 3.1 & 57 & 1 & 50 \\
49 & 460.1 & 9.6 & 9.0 & 94 & 1 & 51 \\
50 & 465.5 & 5.4 & 2.9 & 54 & 1 & 51 \\
51 & 473.5 & 8.0 & 3.8 & 48 & 1 & 52 \\
52 & 477.6 & 4.1 & 3.3 & 80 & 1 & 53 \\
53 & 484.2 & 6.6 & 2.4 & 36 & 1 & 53 \\
54 & 489.4 & 5.2 & 1.3 & 25 & 1 & 54 \\
55 & 492.2 & 2.8 & 1.9 & 68 & 1 & 54 \\
56 & 498.2 & 6.0 & 3.7 & 62 & 1 & 55 \\
57 & 503.6 & 5.4 & 2.7 & 50 & 1 & 56 \\
58 & 511.5 & 7.9 & 2.5 & 32 & 1 & 56 \\
59 & 518.7 & 7.2 & 6.8 & 94 & 1 & 57 \\
60 & 523.0 & 4.3 & 3.9 & 91 & 1 & 58 \\
61 & 530.1 & 7.1 & 3.2 & 45 & 1 & 59 \\
\hline & & & & & & \\
\hline
\end{tabular}


Table C-1: Core Recovery Data (Continued)

[Sources (Data-tracking numbers, DTNs): 1-TM0000000SD9RS.001;

2-TM0000000SD9RS.002; 3-TM0000000SD9RS.003; 4-TM0000000SD9RS.004]

\begin{tabular}{ccccccc}
\hline $\begin{array}{c}\text { Run } \\
\text { No. }\end{array}$ & $\begin{array}{c}\text { Interval } \\
\text { Bottom } \\
\text { (feet) }\end{array}$ & $\begin{array}{c}\text { Drilled } \\
\text { (feet) }\end{array}$ & $\begin{array}{c}\text { Recovered } \\
\text { (feet) }\end{array}$ & $\begin{array}{c}\text { Core } \\
\text { Recovery } \\
\text { (percent) }\end{array}$ & Source & $\begin{array}{c}\text { Page } \\
\text { No. }\end{array}$ \\
\hline 62 & 537.2 & 7.1 & 2.8 & 39 & 1 & 59 \\
63 & 541.9 & 4.7 & 4.3 & 91 & 1 & 60 \\
64 & 551.2 & 9.3 & 3.0 & 32 & 1 & 60 \\
65 & 555.6 & 4.4 & 3.4 & 77 & 1 & 61 \\
66 & 560.5 & 4.9 & 3.7 & 76 & 1 & 62 \\
67 & 567.8 & 7.3 & 2.0 & 27 & 1 & 62 \\
68 & 574.6 & 6.8 & 1.7 & 25 & 1 & 63 \\
69 & 576.8 & 2.2 & 1.8 & 82 & 1 & 63 \\
70 & 584.9 & 8.1 & 4.6 & 57 & 1 & 64 \\
71 & 590.9 & 6.0 & 5.2 & 87 & 1 & 66 \\
72 & 596.4 & 5.5 & 3.5 & 64 & 1 & 66 \\
73 & 602.3 & 5.9 & 4.2 & 71 & 1 & 68 \\
74 & 611.6 & 9.3 & 7.2 & 77 & 1 & 69 \\
75 & 617.6 & 6.0 & 3.1 & 52 & 1 & 70 \\
76 & 626.9 & 9.3 & 1.4 & 15 & 1 & 70 \\
77 & 636.0 & 9.1 & 5.5 & 60 & 1 & 71 \\
78 & 642.0 & 6.0 & 3.1 & 52 & 1 & 72 \\
79 & 646.9 & 4.9 & 1.0 & 20 & 1 & 72 \\
80 & 649.3 & 2.4 & 1.2 & 50 & 1 & 73 \\
81 & 654.3 & 5.0 & 3.0 & 60 & 1 & 73 \\
82 & 657.3 & 3.0 & 1.4 & 47 & 1 & 74 \\
83 & 662.3 & 5.0 & 2.4 & 48 & 1 & 74 \\
84 & 668.7 & 6.4 & 4.2 & 66 & 1 & 75 \\
85 & 678.0 & 9.3 & 5.6 & 60 & 1 & 76 \\
86 & 687.6 & 9.6 & 6.3 & 66 & 1 & 78 \\
87 & 696.5 & 8.9 & 6.6 & 74 & 1 & 79 \\
88 & 700.2 & 3.7 & 2.7 & 73 & 1 & 80 \\
89 & 705.9 & 5.7 & 4.3 & 75 & 1 & 81 \\
90 & 714.4 & 8.5 & 7.7 & 91 & 1 & 83 \\
91 & 720.4 & 6.0 & 5.4 & 90 & 1 & 84 \\
92 & 724.5 & 4.1 & 3.2 & 78 & 1 & 85 \\
\hline & & & & & & \\
\hline
\end{tabular}

Table C-1: Core Recovery Data (Continued)

[Sources (Data-tracking numbers, DTNs): 1-TM0000000SD9RS.001;

2-TM0000000SD9RS.002; 3-TM0000000SD9RS.003; 4-TM0000000SD9RS.004]

\begin{tabular}{|c|c|c|c|c|c|c|}
\hline $\begin{array}{l}\text { Run } \\
\text { No. }\end{array}$ & $\begin{array}{c}\text { Interval } \\
\text { Bottom } \\
\text { (feet) }\end{array}$ & $\begin{array}{c}\text { Drilled } \\
\text { (feet) }\end{array}$ & $\begin{array}{c}\text { Recovered } \\
\text { (feet) }\end{array}$ & $\begin{array}{c}\text { Core } \\
\text { Recovery } \\
\text { (percent) }\end{array}$ & Source & $\begin{array}{c}\text { Page } \\
\text { No. }\end{array}$ \\
\hline 93 & 734.7 & 10.2 & 10.2 & 100 & 1 & 87 \\
\hline 94 & 740.1 & 5.4 & 2.7 & 50 & 1 & 87 \\
\hline 95 & 744.5 & 4.4 & 3.5 & 80 & 1 & 88 \\
\hline 96 & 748.7 & 4.2 & 3.7 & 88 & 1 & 89 \\
\hline 97 & 755.1 & 6.4 & 4.0 & 63 & 1 & 90 \\
\hline 98 & 762.4 & 7.3 & 6.4 & 88 & 1 & 92 \\
\hline 99 & 770.4 & 8.0 & 7.4 & 93 & 1 & 93 \\
\hline 100 & 779.1 & 8.7 & 8.6 & 99 & 1 & 94 \\
\hline 101 & 784.1 & 5.0 & 1.1 & 22 & $\cdot 1$ & 94 \\
\hline 102 & 788.1 & 4.0 & 1.6 & 40 & 1 & 95 \\
\hline 103 & 793.5 & 5.4 & 3.1 & 57 & 1 & 95 \\
\hline 104 & 799.0 & 5.5 & 5.4 & 98 & 1 & 97 \\
\hline 105 & 806.5 & 7.5 & 7.0 & 93 & 1 & 98 \\
\hline 106 & 813.5 & 7.0 & 6.6 & 94 & 1 & 100 \\
\hline 107 & 816.8 & 3.3 & 3.3 & 100 & 1 & 100 \\
\hline 108 & 825.2 & 8.4 & 8.4 & 100 & 1 & 102 \\
\hline 109 & 835.4 & 10.2 & 10.2 & 100 & 1 & 103 \\
\hline 110 & 845.2 & 9.8 & 9.8 & 100 & 1 & 105 \\
\hline 111 & 849.2 & 4.0 & 3.5 & 88 & 1 & 106 \\
\hline 112 & 856.8 & 7.6 & 5.1 & 67 & 1 & 107 \\
\hline 113 & 865.0 & 8.2 & 3.2 & 39 & 1 & 108 \\
\hline 114 & 872.2 & 7.2 & 2.7 & 37 & 1 & 109 \\
\hline 115 & 878.3 & 6.1 & 1.5 & 25 & 1 & 110 \\
\hline 116 & 887.6 & 9.3 & 2.0 & 22 & 1 & 110 \\
\hline 117 & 896.6 & 9.0 & 1.7 & 19 & 1 & 111 \\
\hline 118 & 898.4 & 1.8 & 0.6 & 33 & 1 & 111 \\
\hline 119 & 902.9 & 4.5 & 3.1 & 69 & 1 & 112 \\
\hline 120 & 905.2 & 2.3 & 0.7 & 30 & 1 & 112 \\
\hline 121 & 910.8 & 5.6 & 3.4 & 61 & 1 & 113 \\
\hline 122 & 921.2 & 10.4 & 0.0 & 0 & 1 & 113 \\
\hline 123 & 923.5 & 2.3 & 1.7 & 74 & 1 & 114 \\
\hline
\end{tabular}


Table C-1: Core Recovery Data (Continued)

[Sources (Data-tracking numbers, DTNs): 1-TM0000000SD9RS.001;

2-TM0000000SD9RS.002; 3-TM0000000SD9RS.003; 4-TM0000000SD9RS.004]

\begin{tabular}{|c|c|c|c|c|c|c|}
\hline $\begin{array}{l}\text { Run } \\
\text { No. }\end{array}$ & $\begin{array}{c}\text { Interval } \\
\text { Bottom } \\
\text { (feet) }\end{array}$ & $\begin{array}{l}\text { Drilled } \\
\text { (feet) }\end{array}$ & $\begin{array}{l}\text { Recovered } \\
\text { (feet) }\end{array}$ & $\begin{array}{c}\text { Core } \\
\text { Recovery } \\
\text { (percent) }\end{array}$ & Source & $\begin{array}{l}\text { Page } \\
\text { No. }\end{array}$ \\
\hline 124 & 928.5 & 5.0 & 1.9 & 38 & 1 & 114 \\
\hline 125 & 933.3 & 4.8 & 2.3 & 48 & 1 & 115 \\
\hline 126 & 937.8 & 4.5 & 3.7 & 82 & 1 & 116 \\
\hline 127 & 942.9 & 5.1 & 2.4 & 47 & 1 & 117 \\
\hline 128 & 948.0 & 5.1 & 3.4 & 67 & 1 & 118 \\
\hline 129 & 952.4 & 4.4 & 0.8 & 18 & 1 & 118 \\
\hline 130 & 957.5 & 5.1 & 2.7 & 53 & 1 & 119 \\
\hline 131 & 962.6 & 5.1 & 1.8 & 35 & 1 & 120 \\
\hline 132 & 966.5 & 3.9 & 3.4 & 87 & 1 & 121 \\
\hline 133 & 971.6 & 5.1 & 3.7 & 73 & 1 & 121 \\
\hline 134 & 975.4 & 3.8 & 2.6 & 68 & 1 & 122 \\
\hline 135 & 979.8 & 4.4 & 1.6 & 36 & 1 & 123 \\
\hline 136 & 984.4 & 4.6 & 3.3 & 72 & 1 & 124 \\
\hline 137 & 989.5 & 5.1 & 4.4 & 86 & 1 & 125 \\
\hline 138 & 994.9 & 5.4 & 3.8 & 70 & 1 & 125 \\
\hline 139 & 1001.9 & 7.0 & 3.9 & 56 & 1 & 126 \\
\hline 140 & 1006.7 & 4.8 & 2.5 & 52 & 1 & 127 \\
\hline 141 & 1011.4 & 4.7 & 1.1 & 23 & 1 & 127 \\
\hline 142 & 1016.8 & 5.4 & 2.7 & 50 & 1 & 128 \\
\hline 143 & 1020.5 & 3.7 & 1.0 & 27 & 1 & 129 \\
\hline 144 & 1022.6 & 2.1 & 1.4 & 67 & 1 & 129 \\
\hline 145 & 1027.7 & 5.1 & 2.0 & 39 & 1 & 130 \\
\hline 146 & 1032.8 & 5.1 & 3.6 & 71 & 1 & 131 \\
\hline 147 & 1037.8 & 5.0 & 4.7 & 94 & 1 & 132 \\
\hline 148 & 1043.5 & 5.7 & 4.6 & 81 & 1 & 133 \\
\hline 149 & 1051.1 & 7.6 & 7.2 & 95 & 1 & 134 \\
\hline 150 & 1053.2 & 2.1 & 1.8 & 86 & 1 & 134 \\
\hline 151 & 1059.7 & 6.5 & 3.8 & 58 & 1 & 135 \\
\hline 152 & 1066.0 & 6.3 & 5.9 & 94 & 1 & 136 \\
\hline 153 & 1075.4 & 9.4 & 5.4 & 57 & 1 & 137 \\
\hline 154 & 1079.8 & 4.4 & 2.2 & 50 & 1 & 138 \\
\hline
\end{tabular}

Table C-1: Core Recovery Data (Continued)

[Sources (Data-tracking numbers, DTNs): 1-TM0000000SD9RS.001;

2-TM0000000SD9RS.002; 3-TM0000000SD9RS.003; 4-TM0000000SD9RS.004]

\begin{tabular}{ccccccc}
\hline $\begin{array}{c}\text { Run } \\
\text { No. }\end{array}$ & $\begin{array}{c}\text { Interval } \\
\text { Bottom } \\
\text { (feet) }\end{array}$ & $\begin{array}{c}\text { Drilled } \\
\text { (feet) }\end{array}$ & $\begin{array}{c}\text { Recovered } \\
\text { (feet) }\end{array}$ & $\begin{array}{c}\text { Core } \\
\text { Recovery } \\
\text { (percent) }\end{array}$ & Source & $\begin{array}{c}\text { Page } \\
\text { No. }\end{array}$ \\
\hline 155 & 1084.8 & 5.0 & 1.8 & 36 & 1 & 139 \\
156 & 1090.0 & 5.2 & 4.1 & 79 & 1 & 140 \\
157 & 1094.4 & 4.4 & 3.0 & 68 & 1 & 140 \\
158 & 1097.8 & 3.4 & 2.6 & 76 & 1 & 141 \\
159 & 1103.4 & 5.6 & 4.7 & 84 & 1 & 142 \\
160 & 1113.3 & 9.9 & 9.0 & 91 & 1 & 143 \\
161 & 1118.3 & 5.0 & 4.1 & 82 & 1 & 144 \\
162 & 1124.4 & 6.1 & 6.1 & 100 & 1 & 145 \\
163 & 1132.3 & 7.9 & 5.0 & 63 & 1 & 146 \\
164 & 1137.5 & 5.2 & 3.6 & 69 & 1 & 147 \\
165 & 1143.0 & 5.5 & 5.3 & 96 & 1 & 148 \\
166 & 1148.3 & 5.3 & 4.8 & 91 & 1 & 149 \\
167 & 1156.1 & 7.8 & 5.6 & 72 & 1 & 150 \\
168 & 1158.0 & 1.9 & 1.9 & 100 & 1 & 151 \\
169 & 1168.1 & 10.1 & 9.4 & 93 & 1 & 153 \\
170 & 1170.0 & 1.9 & 1.5 & 79 & 1 & 153 \\
171 & 1178.0 & 8.0 & 5.8 & 73 & 1 & 155 \\
172 & 1183.6 & 5.6 & 3.4 & 61 & 1 & 156 \\
173 & 1191.6 & 8.0 & 6.8 & 85 & 1 & 158 \\
174 & 1198.6 & 7.0 & 5.5 & 79 & 1 & 159 \\
175 & 1207.2 & 8.6 & 6.7 & 78 & 1 & 160 \\
176 & 1210.8 & 3.6 & 2.1 & 58 & 1 & 161 \\
177 & 1218.4 & 7.6 & 5.8 & 76 & 1 & 162 \\
178 & 1223.5 & 5.1 & 3.1 & 61 & 1 & 163 \\
179 & 1228.0 & 4.5 & 3.2 & 71 & 1 & 163 \\
180 & 1232.9 & 4.9 & 3.6 & 73 & 1 & 164 \\
181 & 1240.8 & 7.9 & 5.7 & 72 & 1 & 165 \\
182 & 1248.4 & 7.6 & 5.6 & 74 & 1 & 166 \\
183 & 1253.5 & 5.1 & 3.9 & 76 & 1 & 167 \\
184 & 1261.2 & 7.7 & 6.1 & 79 & 1 & 169 \\
185 & 1269.8 & 8.6 & 5.1 & 59 & 1 & 170 \\
\hline & & & & & & \\
\hline
\end{tabular}


Table C-1: Core Recovery Data (Continued)

[Sources (Data-tracking numbers, DTNs): 1-TM0000000SD9RS.001;

2-TM0000000SD9RS.002; 3-TM0000000SD9RS.003; 4-TM0000000SD9RS.004]

\begin{tabular}{|c|c|c|c|c|c|c|}
\hline $\begin{array}{l}\text { Run } \\
\text { No. }\end{array}$ & $\begin{array}{c}\text { Interval } \\
\text { Bottom } \\
\text { (feet) }\end{array}$ & $\begin{array}{c}\text { Drilled } \\
\text { (feet) }\end{array}$ & $\begin{array}{c}\text { Recovered } \\
\text { (feet) }\end{array}$ & $\begin{array}{c}\text { Core } \\
\text { Recovery } \\
\text { (percent) }\end{array}$ & Source & $\begin{array}{l}\text { Page } \\
\text { No. }\end{array}$ \\
\hline 186 & 1273.0 & 3.2 & 3.1 & 97 & 1 & 171 \\
\hline 187 & 1278.0 & 5.0 & 4.2 & 84 & 1 & 172 \\
\hline 188 & 1284.2 & 6.2 & 5.2 & 84 & 1 & 173 \\
\hline 189 & 1288.9 & 4.7 & 2.0 & 43 & 1 & 174 \\
\hline 190 & 1295.7 & 6.8 & 3.8 & 56 & 1 & 175 \\
\hline 191 & 1297.5 & 1.8 & 1.8 & 100 & 1 & 175 \\
\hline 192 & 1307.8 & 10.3 & 8.6 & 83 & 1 & 177 \\
\hline 193 & 1316.7 & 8.9 & 4.8 & 54 & 1 & 178 \\
\hline 194 & 1322.7 & 6.0 & 4.6 & 77 & 1 & 179 \\
\hline 195 & 1328.9 & 6.2 & 3.1 & 50 & 1 & 180 \\
\hline 196 & 1329.7 & 0.8 & 0.6 & 75 & 1 & 180 \\
\hline 197 & 1336.6 & 6.9 & 6.9 & 100 & 1 & 183 \\
\hline 198 & 1346.3 & 9.7 & 4.5 & 46 & 1 & 183 \\
\hline 199 & 1348.1 & 1.8 & 1.8 & 100 & 1 & 184 \\
\hline 200 & 1354.0 & 5.9 & 5.4 & 92 & 1 & 186 \\
\hline 201 & 1359.9 & 5.9 & 5.2 & 88 & 1 & 187 \\
\hline 202 & 1363.1 & 3.2 & 2.8 & 88 & 1 & 188 \\
\hline 203 & 1367.3 & 4.2 & 4.2 & 100 & 1 & 189 \\
\hline 204 & 1377.1 & 9.8 & 8.1 & 83 & 1 & 191 \\
\hline 205 & 1384.4 & 7.3 & 6.6 & 90 & 1 & 193 \\
\hline 206 & 1390.5 & 6.1 & 6.0 & 98 & 1 & 194 \\
\hline 207 & 1400.3 & 9.8 & 7.2 & 73 & 1 & 196 \\
\hline 208 & 1409.9 & 9.6 & 9.4 & 98 & 1 & 198 \\
\hline 209 & 1414.2 & 4.3 & 4.3 & 100 & 1 & 199 \\
\hline 210 & 1422.2 & 8.0 & 7.5 & 94 & 1 & 201 \\
\hline 211 & 1430.5 & 8.3 & 8.3 & 100 & 1 & 202 \\
\hline 212 & 1440.1 & 9.6 & 9.6 & 100 & 1 & 203 \\
\hline 213 & 1449.5 & 9.4 & 9.4 & 100 & 1 & 204 \\
\hline 214 & 1459.1 & 9.6 & 9.6 & 100 & 1 & 205 \\
\hline 215 & 1469.0 & 9.9 & 9.9 & 100 & 1 & 206 \\
\hline 216 & 1474.2 & 5.2 & 5.2 & 100 & 1 & 207 \\
\hline
\end{tabular}

Table C-1: Core Recovery Data (Continued)

[Sources (Data-tracking numbers, DTNs): 1-TM0000000SD9RS.001;

2-TM0000000SD9RS.002; 3-TM0000000SD9RS.003; 4-TM0000000SD9RS.004]

\begin{tabular}{ccccccc}
\hline $\begin{array}{c}\text { Run } \\
\text { No. }\end{array}$ & $\begin{array}{c}\text { Interval } \\
\text { Bottom } \\
\text { (feet) }\end{array}$ & $\begin{array}{c}\text { Drilled } \\
\text { (feet) }\end{array}$ & $\begin{array}{c}\text { Recovered } \\
\text { (feet) }\end{array}$ & $\begin{array}{c}\text { Core } \\
\text { Recovery } \\
\text { (percent) }\end{array}$ & Source & $\begin{array}{c}\text { Page } \\
\text { No. }\end{array}$ \\
\hline 217 & 1479.3 & 5.1 & 5.1 & 100 & 1 & 207 \\
218 & 1484.2 & 4.9 & 4.9 & 100 & 1 & 208 \\
219 & 1489.2 & 5.0 & 5.0 & 100 & 1 & 209 \\
220 & 1490.7 & 1.5 & 0.2 & 13 & 2 & 209 \\
221 & 1491.7 & 1.0 & 0.9 & 90 & 2 & 209 \\
222 & 1492.0 & 0.3 & 0.3 & 100 & 2 & 209 \\
223 & 1497.9 & 5.9 & 5.9 & 100 & 2 & 210 \\
224 & 1507.2 & 9.3 & 9.3 & 100 & 2 & 211 \\
225 & 1516.7 & 9.5 & 9.5 & 100 & 2 & 212 \\
226 & 1526.4 & 9.7 & 9.7 & 100 & 2 & 214 \\
227 & 1536.6 & 10.2 & 10.2 & 100 & 2 & 215 \\
228 & 1542.4 & 5.8 & 5.4 & 93 & 2 & 215 \\
229 & 1547.4 & 5.0 & 5.8 & 116 & 2 & 216 \\
230 & 1556.9 & 9.5 & 5.0 & 53 & 2 & 217 \\
231 & 1566.4 & 9.5 & 9.5 & 100 & 2 & 218 \\
232 & 1576.1 & 9.7 & 9.7 & 100 & 2 & 219 \\
233 & 1585.6 & 9.5 & 9.5 & 100 & 2 & 221 \\
234 & 1595.3 & 9.7 & 9.7 & 100 & 2 & 222 \\
235 & 1604.8 & 9.5 & 9.5 & 100 & 2 & 224 \\
236 & 1609.3 & 4.5 & 1.7 & 38 & 2 & 224 \\
237 & 1615.5 & 6.2 & 7.2 & 116 & 2 & 225 \\
238 & 1626.1 & 10.6 & 9.2 & 87 & 2 & 227 \\
239 & 1635.7 & 9.6 & 7.4 & 77 & 2 & 228 \\
240 & 1645.3 & 9.6 & 9.6 & 100 & 2 & 228 \\
241 & 1654.8 & 9.5 & 9.5 & 100 & 2 & 229 \\
242 & 1664.2 & 9.4 & 9.4 & 100 & 2 & 230 \\
243 & 1671.4 & 7.2 & 7.2 & 100 & 2 & 231 \\
244 & 1681.1 & 9.7 & 9.7 & 100 & 2 & 232 \\
245 & 1690.6 & 9.5 & 9.5 & 100 & 2 & 232 \\
246 & 1700.5 & 9.9 & 9.9 & 100 & 3 & 233 \\
247 & 1710.2 & 9.7 & 9.7 & 100 & 3 & 234 \\
\hline & & & & & & \\
\hline
\end{tabular}


Table C-1: Core Recovery Data (Continued)

[Sources (Data-tracking numbers, DTNs): 1-TM0000000SD9RS.001; 2-TM0000000SD9RS.002; 3-TM0000000SD9RS.003; 4-TM0000000SD9RS.004]

\begin{tabular}{|c|c|c|c|c|c|c|}
\hline $\begin{array}{l}\text { Run } \\
\text { No. }\end{array}$ & $\begin{array}{c}\text { Interval } \\
\text { Bottom } \\
\text { (feet) }\end{array}$ & $\begin{array}{c}\text { Drilled } \\
\text { (feet) }\end{array}$ & $\begin{array}{l}\text { Recovered } \\
\text { (feet) }\end{array}$ & $\begin{array}{c}\text { Core } \\
\text { Recovery } \\
\text { (percent) }\end{array}$ & Source & $\begin{array}{c}\text { Page } \\
\text { No. }\end{array}$ \\
\hline 248 & 1720.0 & 9.8 & 9.8 & 100 & 3 & 235 \\
\hline 249 & 1729.6 & 9.6 & 10.1 & 105 & 3 & 235 \\
\hline 250 & 1739.2 & 9.6 & 9.5 & 99 & 3 & 237 \\
\hline 251 & 1739.8 & 0.6 & 0.6 & 100 & 3 & 237 \\
\hline 252 & 1749.7 & 9.9 & 9.9 & 100 & 3 & 238 \\
\hline 253 & 1759.0 & 9.3 & 9.2 & 99 & 3 & 239 \\
\hline 254 & 1761.6 & 2.6 & 2.6 & 100 & 3 & 239 \\
\hline 255 & 1771.2 & 9.6 & 9.6 & 100 & 3 & 240 \\
\hline 256 & 1780.7 & 9.5 & 9.5 & 100 & 3 & 241 \\
\hline 257 & 1790.5 & 9.8 & 9.8 & 100 & 3 & 241 \\
\hline 258 & 1800.1 & 9.6 & 9.6 & 100 & 3 & 242 \\
\hline 259 & 1809.7 & 9.6 & 9.6 & 100 & 3 & 243 \\
\hline 260 & 1819.2 & 9.5 & 9.5 & 100 & 3 & 243 \\
\hline 261 & 1828.7 & 9.5 & 9.5 & 100 & 3 & 244 \\
\hline 262 & 1838.0 & 9.3 & 9.2 & 99 & 3 & 246 \\
\hline 263 & 1845.1 & 7.1 & 7.1 & 100 & 3 & 246 \\
\hline 264 & 1852.7 & 7.6 & 7.6 & 100 & 3 & 247 \\
\hline 265 & 1862.4 & 9.7 & 9.7 & 100 & 3 & 247 \\
\hline 266 & 1872.1 & 9.7 & 9.7 & 100 & 3 & 249 \\
\hline 267 & 1881.7 & 9.6 & 9.6 & 100 & 3 & 250 \\
\hline 268 & 1891.1 & 9.4 & 9.4 & 100 & 3 & 251 \\
\hline 269 & 1900.6 & 9.5 & 9.5 & 100 & 3 & 252 \\
\hline 270 & 1910.0 & 9.4 & 9.4 & 100 & 3 & 252 \\
\hline 271 & 1916.1 & 6.1 & 4.4 & 72 & 3 & 254 \\
\hline 272 & 1923.1 & 7.0 & 5.7 & 81 & 3 & 254 \\
\hline 273 & 1932.2 & 9.1 & 9.1 & 100 & 3 & 255 \\
\hline 274 & 1938.7 & 6.5 & 6.5 & 100 & 3 & 256 \\
\hline 275 & 1942.0 & 3.3 & 1.3 & 39 & 3 & 256 \\
\hline 276 & 1950.0 & 8.0 & 7.5 & 94 & 3 & 257 \\
\hline 277 & 1959.3 & 9.3 & 9.3 & 100 & 3 & 259 \\
\hline 278 & 1968.4 & 9.1 & 8.9 & 98 & 3 & 259 \\
\hline
\end{tabular}

Table C-1: Core Recovery Data (Continued)

[Sources (Data-tracking numbers, DTNs): 1-TM0000000SD9RS.001; 2-TM0000000SD9RS.002; 3-TM0000000SD9RS.003; 4-TM0000000SD9RS.004]

\begin{tabular}{rrrrrrr}
\hline $\begin{array}{c}\text { Run } \\
\text { No. }\end{array}$ & $\begin{array}{c}\text { Interval } \\
\text { Bottom } \\
\text { (feet) }\end{array}$ & $\begin{array}{c}\text { Drilled } \\
\text { (feet) }\end{array}$ & $\begin{array}{c}\text { Recovered } \\
\text { (feet) }\end{array}$ & $\begin{array}{c}\text { Core } \\
\text { Recovery } \\
\text { (percent) }\end{array}$ & Source & $\begin{array}{c}\text { Page } \\
\text { No. }\end{array}$ \\
\hline 279 & 1978.4 & 10.0 & 10.0 & 100 & 3 & 260 \\
280 & 1988 & 9.6 & 9.0 & 94 & 3 & 261 \\
281 & 1991.4 & 3.4 & 3.4 & 100 & 3 & 261 \\
282 & 1994.5 & 3.1 & .3 .1 & 100 & 3 & 262 \\
283 & 2002.3 & 7.8 & 7.8 & 100 & 3 & 262 \\
284 & 2011.6 & 9.3 & 9.3 & 100 & 3 & 263 \\
285 & 2021.1 & 9.5 & 9.5 & 100 & 3 & 263 \\
286 & 2030.6 & 9.5 & 9.5 & 100 & 3 & 263 \\
287 & 2039.9 & 9.3 & 9.2 & 99 & 4 & 264 \\
288 & 2049.2 & 9.3 & 9.3 & 100 & 4 & 265 \\
289 & 2057.9 & 8.7 & 8.3 & 95 & 4 & 266 \\
290 & 2067.4 & 9.5 & 9.5 & 100 & 4 & 267 \\
291 & 2076.9 & 9.5 & 9.5 & 100 & 4 & 268 \\
292 & 2086.9 & 10.0 & 10.0 & 100 & 4 & 269 \\
293 & 2096.7 & 9.8 & 9.7 & 99 & 4 & 270 \\
294 & 2106.1 & 9.4 & 9.4 & 100 & 4 & 271 \\
295 & 2115.7 & 9.6 & 9.6 & 100 & 4 & 272 \\
296 & 2125.2 & 9.5 & 9.5 & 100 & 4 & 273 \\
297 & 2135.2 & 10.0 & 9.9 & 99 & 4 & 275 \\
298 & 2141.8 & 6.6 & 6.3 & 95 & 4 & 276 \\
299 & 2150.7 & 8.9 & 8.3 & 93 & 4 & 276 \\
300 & 2160.4 & 9.7 & 9.7 & 100 & 4 & 277 \\
301 & 2169.9 & 9.5 & 9.5 & 100 & 4 & 277 \\
302 & 2175.0 & 5.1 & 5.1 & 100 & 4 & 278 \\
303 & 2184.6 & 9.6 & 9.5 & 99 & 4 & 278 \\
304 & 2194.6 & 10.0 & 10.0 & 100 & 4 & 279 \\
305 & 2204.3 & 9.7 & 9.7 & 100 & 4 & 280 \\
306 & 2213.9 & 9.6 & 9.2 & 96 & 4 & 281 \\
307 & 2223.1 & 9.2 & 9.2 & 100 & 4 & \\
\hline & & & & & &
\end{tabular}




\section{Appendix D: Rock Quality Designation (RQD) Data}


Table D-1: Core-Run RQD Data

[Source (DTN): TM0000SD9SUPER.002]

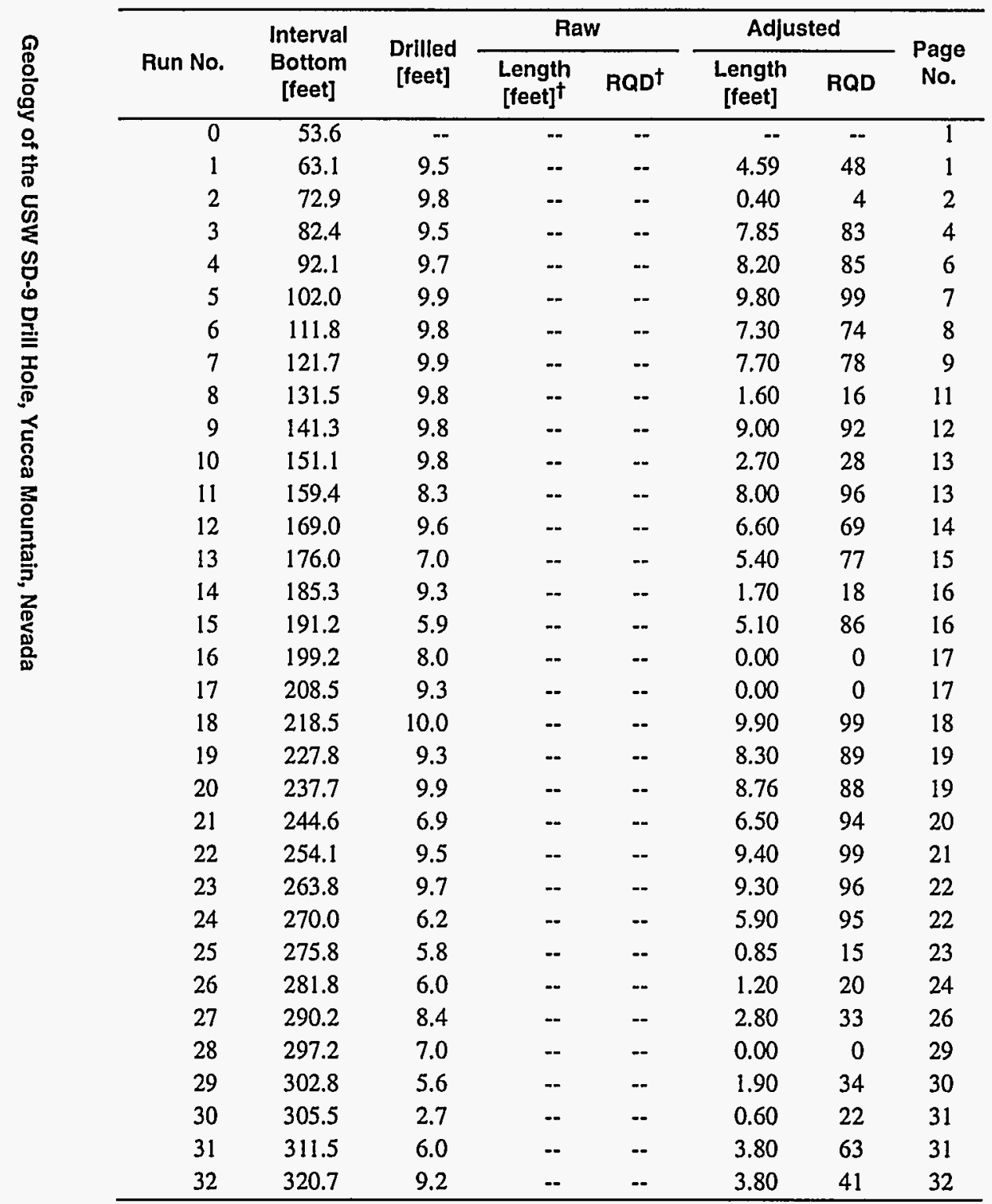

Table D-1: Core-Run RQD Data (Continued)

[Source (DTN): TM0000SD9SUPER.002]

\begin{tabular}{|c|c|c|c|c|c|c|c|}
\hline \multirow[b]{2}{*}{ Run No. } & \multirow{2}{*}{$\begin{array}{c}\text { Interval } \\
\text { Bottom } \\
\text { [feet] }\end{array}$} & \multirow{2}{*}{$\begin{array}{c}\text { Drilled } \\
\text { [feet] }\end{array}$} & \multicolumn{2}{|c|}{ Raw } & \multicolumn{2}{|c|}{ Adjusted } & \multirow{2}{*}{$\begin{array}{c}\text { Page } \\
\text { No. }\end{array}$} \\
\hline & & & $\begin{array}{l}\text { Length } \\
\text { [feet] }^{\dagger}\end{array}$ & RQD' & $\begin{array}{c}\text { Length } \\
\text { [feet] }\end{array}$ & RQD & \\
\hline 33 & 330.3 & 9.6 & -- & - & 7.80 & 81 & 33 \\
\hline 34 & 337.4 & 7.1 & -- & -- & 6.10 & 86 & 34 \\
\hline 35 & 347.2 & 9.8 & -- & -- & 8.20 & 84 & 35 \\
\hline 36 & 356.5 & 9.3 & -- & -- & 5.40 & 58 & 36 \\
\hline 37 & 361.3 & 4.8 & -- & -- & 0.80 & 17 & 38 \\
\hline 38 & 368.1 & 6.8 & -- & -- & 2.70 & 40 & 39 \\
\hline 39 & 375.6 & 7.5 & -- & -- & 3.00 & 40 & 41 \\
\hline 40 & 384.9 & 9.3 & -- & -- & 6.00 & 65 & 42 \\
\hline 41 & 393.4 & 8.5 & -- & -- & 1.60 & 19 & 44 \\
\hline 42 & 402.3 & 8.9 & -- & -- & 8.40 & 94 & 45 \\
\hline 43 & 409.5 & 7.2 & -- & -- & 3.80 & 53 & 46 \\
\hline 44 & 419.0 & 9.5 & -- & -- & 0.00 & 0 & 47 \\
\hline 45 & 428.6 & 9.6 & -- & -- & 2.40 & 25 & 47 \\
\hline 46 & 435.9 & 7.3 & -- & - & 5.30 & 73 & 47 \\
\hline 47 & 445.1 & 9.2 & -- & -- & 2.40 & 26 & 48 \\
\hline 48 & 450.5 & 5.4 & -- & -- & 1.25 & 23 & 49 \\
\hline 49 & 460.1 & 9.6 & -- & -- & 8.20 & 85 & 50 \\
\hline 50 & 465.5 & 5.4 & -- & -- & 0.40 & 7 & 51 \\
\hline 51 & 473.5 & 8.0 & -- & -- & 3.10 & 39 & 51 \\
\hline 52 & 477.6 & 4.1 & -- & -- & 2.10 & 51 & 52 \\
\hline 53 & 484.2 & 6.6 & -- & - & 0.00 & 0 & 53 \\
\hline 54 & 489.4 & 5.2 & -- & -- & 1.00 & 19 & 53 \\
\hline 55 & 492.2 & 2.8 & -. & -- & 1.40 & 50 & 54 \\
\hline 56 & 498.2 & 6.0 & -- & -- & 1.20 & 20 & 54 \\
\hline 57 & 503.6 & 5.4 & -- & -- & 1.90 & 35 & 55 \\
\hline 58 & 511.5 & 7.9 & -- & -- & 0.00 & 0 & 56 \\
\hline 59 & 518.7 & 7.2 & -- & -- & 6.70 & 93 & 56 \\
\hline 60 & 523.0 & 4.3 & -. & -- & 0.39 & 9 & 57 \\
\hline 61 & 530.1 & 7.1 & -. & -- & 1.96 & 28 & 58 \\
\hline 62 & 537.2 & 7.1 & -. & -- & 1.78 & 25 & 59 \\
\hline 63 & 541.9 & 4.7 & -. & - & 3.58 & 76 & 59 \\
\hline 64 & 551.2 & 9.3 & -- & -- & 0.00 & 0 & 60 \\
\hline 65 & 555.6 & 4.4 & -- & -- & 2.97 & 68 & 60 \\
\hline
\end{tabular}


Table D-1: Core-Run RQD Data (Continued)

[Source (DTN): TM0000SD9SUPER.002]

\begin{tabular}{|c|c|c|c|c|c|c|c|}
\hline \multirow[b]{2}{*}{ Run No. } & \multirow{2}{*}{$\begin{array}{c}\text { Interval } \\
\text { Bottom } \\
\text { [feet] }\end{array}$} & \multirow{2}{*}{$\begin{array}{c}\text { Drilled } \\
\text { [feet] }\end{array}$} & \multicolumn{2}{|c|}{ Raw } & \multicolumn{2}{|c|}{ Adjusted } & \multirow{2}{*}{$\begin{array}{c}\text { Page } \\
\text { No. }\end{array}$} \\
\hline & & & $\begin{array}{l}\text { Length } \\
\text { [feet] }]^{\dagger}\end{array}$ & RQD' & $\begin{array}{l}\text { Length } \\
\text { [feet] }\end{array}$ & RQD & \\
\hline 66 & 560.5 & 4.9 & -- & - & 1.61 & 33 & 61 \\
\hline 67 & 567.8 & 7.3 & -- & -- & 0.00 & 0 & 62 \\
\hline 68 & 574.6 & 6.8 & -- & -- & 1.00 & 15 & 62 \\
\hline 69 & 576.8 & 2.2 & -- & -- & 1.00 & 45 & 63 \\
\hline 70 & 584.9 & 8.1 & -- & -- & 1.90 & 23 & 63 \\
\hline 71 & 590,9 & 6.0 & - & -- & 4.60 & 77 & 64 \\
\hline 72 & 596.4 & 5.5 & - &.- & 2,90 & 53 & 66 \\
\hline 73 & 602.3 & 5.9 & -- & -- & 2,70 & 46 & 66 \\
\hline 74 & 611.6 & 9.3 & - & - & 5.10 & 55 & 68 \\
\hline 75 & 617.6 & 6.0 & -- & - & 2,23 & 37 & 69 \\
\hline 76 & 626.9 & 9.3 & -- & -- & 0.00 & 0 & 70 \\
\hline 77 & 636,0 & 9.1 & -- & -- & 4.90 & 54 & 70 \\
\hline 78 & 642,0 & 6.0 & -- & -- & 1.81 & 30 & 71 \\
\hline 79 & 646.9 & 4.9 & -. & -. & 0.59 & 12 & 72 \\
\hline 80 & 649.3 & 2.4 & -- & -- & 0.00 & 0 & 72 \\
\hline 81 & 654.3 & 5.0 & -- & -- & 1.90 & 38 & 73 \\
\hline 82 & 657.3 & 3.0 & -- & -- & 0.00 & 0 & 73 \\
\hline 83 & 662,3 & 5.0 & -- & $\cdots$ & 1.70 & 34 & 74 \\
\hline 84 & 668.7 & 6.4 & -- & -- & 3,56 & 56 & 74 \\
\hline 85 & 678,0 & 9.3 & -- & -- & 5.03 & 54 & 75 \\
\hline 86 & 687.6 & 9.6 & -- & -- & 5.83 & 61 & 76 \\
\hline 87 & 696.5 & 8.9 & -- & -- & 6.00 & 67 & 78 \\
\hline 88 & 700,2 & 3.7 & -- & -- & 1.40 & 38 & 79 \\
\hline 89 & 705.9 & 5.7 & -- & -- & 3.80 & 67 & 80 \\
\hline 90 & 714.4 & 8.5 & -- & -- & 7,10 & 84 & 81 \\
\hline 91 & 720.4 & 6.0 & -- & -- & 3.90 & 65 & 83 \\
\hline 92 & 724.5 & 4.1 & -- & -- & 1.80 & 44 & 84 \\
\hline 93 & 734.7 & 10.2 & -- & -- & 9.90 & 97 & 85 \\
\hline 94 & 740.1 & 5.4 & -- & -- & 2.80 & 52 & 87 \\
\hline 95 & 744.5 & 4.4 & -- & -- & 0.40 & 9 & 87 \\
\hline 96 & 748.7 & 4.2 & -. & -- & 1.30 & 31 & 88 \\
\hline 97 & 755.1 & 6.4 & -- & -- & 1.30 & 20 & 89 \\
\hline 98 & 762.4 & 7.3 & -- & -- & 3.00 & 41 & 90 \\
\hline
\end{tabular}

Table D-1: Core-Run RQD Data (Continued)

[Source (DTN): TM0000SD9SUPER.002]

\begin{tabular}{|c|c|c|c|c|c|c|c|}
\hline \multirow[b]{2}{*}{ Run No. } & \multirow{2}{*}{$\begin{array}{c}\text { Interval } \\
\text { Bottom } \\
\text { [feet] }\end{array}$} & \multirow{2}{*}{$\begin{array}{l}\text { Drilled } \\
\text { [feet] }\end{array}$} & \multicolumn{2}{|c|}{ Raw } & \multicolumn{2}{|c|}{ Adjusted } & \multirow{2}{*}{$\begin{array}{c}\text { Page } \\
\text { No. }\end{array}$} \\
\hline & & & $\begin{array}{l}\text { Length } \\
\text { [feet] }^{\dagger}\end{array}$ & $\operatorname{RQD}^{\dagger}$ & $\begin{array}{c}\text { Length } \\
\text { [feet] }\end{array}$ & RQD & \\
\hline 99 & 770.4 & 8.0 & -- & -- & 6.17 & 77 & 92 \\
\hline 100 & 779.1 & 8.7 & -- & -- & 7.24 & 83 & 93 \\
\hline 101 & 784.1 & 5.0 & -- & - & 0.00 & 0 & 94 \\
\hline 102 & 788.1 & 4.0 & -- & $\cdots$ & 0.00 & 0 & 94 \\
\hline 103 & 793.5 & 5.4 & -- & $-\cdot$ & 1.00 & 19 & 95 \\
\hline 104 & 799,0 & 5.5 & -- & - & 3.06 & 56 & 95 \\
\hline 105 & 806.5 & 7.5 & -- & -- & 2.74 & 37 & 97 \\
\hline 106 & 813.5 & 7.0 & -- & -- & 4.20 & 60 & 98 \\
\hline 107 & 816.8 & 3.3 & -- & -- & 2.40 & 73 & 100 \\
\hline 108 & 825.2 & 8,4 & -- & -- & 7.45 & 89 & 100 \\
\hline 109 & 835.4 & 10.2 & -- & -- & 8.10 & 79 & 102 \\
\hline 110 & 845,2 & 9.8 & -- & -- & 9.25 & 94 & 103 \\
\hline 111 & 849.2 & 4.0 & -- & -- & 3.50 & 88 & 105 \\
\hline 112 & 856.8 & 7.6 & -- & -- & 4.70 & 62 & 106 \\
\hline 113 & 865,0 & 8.2 & -- & -- & 0.90 & 11 & 107 \\
\hline 114 & 872,2 & 7.2 & -- & -- & 1.50 & 21 & 108 \\
\hline 115 & 878.3 & 6.1 & -- & -- & 0.50 & 8 & 109 \\
\hline 116 & 887.6 & 9.3 & -- & -- & 1.00 & 11 & 110 \\
\hline 117 & 896.6 & 9.0 & $-\cdots$ & -- & 0.00 & 0 & 110 \\
\hline 118 & 898.4 & 1.8 & -- & -- & 0,40 & 22 & 111 \\
\hline 119 & 902.9 & 4.5 & - & -. & 2.90 & 64 & 111 \\
\hline 120 & 905,2 & 2.3 & -- & - & 1.10 & 48 & 112 \\
\hline 121 & 910,8 & 5.6 & -. & - & 1.50 & 27 & 112 \\
\hline 122 & 921.2 & 10.4 & -- & -. & 0.00 & 0 & 113 \\
\hline 123 & 923.5 & 2.3 & -- & -- & 0.58 & 25 & 113 \\
\hline 124 & 928.5 & 5.0 & -. & -- & 1.00 & 20 & 114 \\
\hline 125 & 933.3 & 4.8 & -- & -- & 0.92 & 19 & 114 \\
\hline 126 & 937.8 & 4.5 & -- & - & 1.26 & 28 & 115 \\
\hline 127 & 942.9 & 5.1 & -- & - & 0.50 & 10 & 116 \\
\hline 128 & 948.0 & 5.1 & -- & -- & 3.36 & 66 & 117 \\
\hline 129 & 952.4 & 4.4 & 0.46 & 10 & 0.46 & 10 & 118 \\
\hline 130 & 957.5 & 5.1 & 0.37 & 7 & 0.80 & 16 & 118 \\
\hline 131 & 962.6 & 5.1 & 0.00 & 0 & 1.11 & 22 & 119 \\
\hline
\end{tabular}


Table D-1: Core-Run RQD Data (Continued)

[Source (DTN): TM0000SD9SUPER.002]

\begin{tabular}{|c|c|c|c|c|c|c|c|}
\hline \multirow[b]{2}{*}{ Run No. } & \multirow{2}{*}{$\begin{array}{c}\text { Interval } \\
\text { Bottom } \\
\text { [feet] }\end{array}$} & \multirow{2}{*}{$\begin{array}{c}\text { Drilled } \\
\text { [feet] }\end{array}$} & \multicolumn{2}{|c|}{ Raw } & \multicolumn{2}{|c|}{ Adjusted } & \multirow{2}{*}{$\begin{array}{c}\text { Page } \\
\text { No. }\end{array}$} \\
\hline & & & $\begin{array}{l}\text { Length } \\
\text { [feet] }{ }^{\dagger}\end{array}$ & $R Q D^{\dagger}$ & $\begin{array}{c}\text { Length } \\
\text { [feet] }\end{array}$ & RQD & \\
\hline 132 & 966.5 & 3.9 & 1.39 & 36 & 1.00 & 26 & 120 \\
\hline 133 & 971.6 & 5.1 & -. & -- & 0.90 & 18 & 121 \\
\hline 134 & 975.4 & 3.8 & -- & -- & 1.15 & 30 & 121 \\
\hline 135 & 979.8 & 4.4 & -- & - & 0.00 & 0 & 122 \\
\hline 136 & 984.4 & 4.6 & 0.00 & 0 & 1.49 & 32 & 123 \\
\hline 137 & 989.5 & 5.1 & 0.00 & 0 & 1.23 & 24 & 124 \\
\hline 138 & 994.9 & 5.4 & 0.75 & 14 & 2.30 & 43 & 125 \\
\hline 139 & 1001.9 & 7.0 & 0.69 & 10 & 2.18 & 31 & 125 \\
\hline 140 & 1006.7 & 4.8 & 0.00 & 0 & 1.21 & 25 & 126 \\
\hline 141 & 1011.4 & 4.7 & 0.00 & 0 & 0.50 & 11 & 127 \\
\hline 142 & 1016.8 & 5.4 & 0.73 & 14 & 1.80 & 33 & 127 \\
\hline 143 & 1020.5 & 3.7 & -- & -- & 0.80 & 22 & 128 \\
\hline 144 & 1022.6 & 2.1 & -- & -- & 0.00 & 0 & 129 \\
\hline 145 & 1027.7 & 5.1 & -- & -- & 0.70 & 14 & 129 \\
\hline 146 & 1032.8 & 5.1 & -- & -- & 2.88 & 56 & 130 \\
\hline 147 & 1037.8 & 5.0 & -- & - & 4.11 & 82 & 131 \\
\hline 148 & 1043.5 & 5.7 & -- & - & 4.60 & 81 & 132 \\
\hline 149 & 1051.1 & 7.6 & -- & -- & 5.59 & 74 & 133 \\
\hline 150 & 1053.2 & 2.1 & 0.00 & 0 & 0.93 & 44 & 134 \\
\hline 151 & 1059.7 & 6.5 & 1.99 & 31 & 2.45 & 38 & 134 \\
\hline 152 & 1066.0 & 6.3 & 1.14 & 18 & 3.81 & 60 & 135 \\
\hline 153 & 1075.4 & 9.4 & 1.09 & 12 & 3.06 & 33 & 136 \\
\hline 154 & 1079.8 & 4.4 & 0.00 & 0 & 0.40 & 9 & 137 \\
\hline 155 & 1084.8 & 5.0 & 0.90 & 18 & 0.90 & 18 & 138 \\
\hline 156 & 1090.0 & 5.2 & 0.36 & 7 & 1.80 & 35 & 139 \\
\hline 157 & 1094.4 & 4.4 & 1.59 & 36 & 1.80 & 41 & 140 \\
\hline 158 & 1097.8 & 3.4 & 0.80 & 24 & 1.10 & 32 & 140 \\
\hline 159 & 1103.4 & 5.6 & 2.16 & 39 & 3.35 & 60 & 141 \\
\hline 160 & 1113.3 & 9.9 & 6.91 & 70 & 7.40 & 75 & 142 \\
\hline 161 & 1118.3 & 5.0 & 2.15 & 43 & 3.04 & 61 & 143 \\
\hline 162 & 1124.4 & 6.1 & 2.96 & 49 & 3.52 & 58 & 144 \\
\hline 163 & 1132.3 & 7.9 & 1.41 & 18 & 3.19 & 40 & 145 \\
\hline 164 & 1137.5 & 5.2 & 0.00 & 0 & 0.00 & 0 & 146 \\
\hline
\end{tabular}

Table D-1: Core-Run RQD Data (Continued)

[Source (DTN): TM0000SD9SUPER.002]

\begin{tabular}{|c|c|c|c|c|c|c|c|}
\hline \multirow[b]{2}{*}{ Run No. } & \multirow{2}{*}{$\begin{array}{c}\text { Interval } \\
\text { Bottom } \\
\text { [feet] }\end{array}$} & \multirow{2}{*}{$\begin{array}{l}\text { Drilled } \\
\text { [feet] }\end{array}$} & \multicolumn{2}{|c|}{ Raw } & \multicolumn{2}{|c|}{ Adjusted } & \multirow{2}{*}{$\begin{array}{c}\text { Page } \\
\text { No. }\end{array}$} \\
\hline & & & $\begin{array}{l}\text { Length } \\
\text { [feet] }\end{array}$ & $R^{\prime} D^{\dagger}$ & $\begin{array}{c}\text { Length } \\
\text { [feet] }\end{array}$ & RQD & \\
\hline 165 & 1143.0 & 5.5 & 2.07 & 38 & 3.23 & 59 & 147 \\
\hline 166 & 1148.3 & 5.3 & 2.56 & 48 & 2.67 & 50 & 148 \\
\hline 167 & 1156.1 & 7.8 & 2.02 & 26 & 2.43 & 31 & 149 \\
\hline 168 & 1158.0 & 1.9 & 0.00 & 0 & 0.00 & 0 & 150 \\
\hline 169 & 1168.1 & 10.1 & 3.92 & 39 & 7.86 & 78 & 151 \\
\hline 170 & 1170.0 & 1.9 & 0.00 & 0 & 0.50 & 26 & 153 \\
\hline 171 & 1178.0 & 8.0 & 1.21 & 15 & 2.07 & 26 & 153 \\
\hline 172 & 1183.6 & 5.6 & 0.38 & 7 & 1.33 & 24 & 155 \\
\hline 173 & 1191.6 & 8.0 & 1.85 & 23 & 2.45 & 31 & 156 \\
\hline 174 & 1198.6 & 7.0 & 1.00 & 14 & 2.30 & 33 & 158 \\
\hline 175 & 1207.2 & 8.6 & 1.20 & 14 & 1.70 & 20 & 159 \\
\hline 176 & 1210.8 & 3.6 & 0.73 & 20 & 0.73 & 20 & 160 \\
\hline 177 & 1218.4 & 7.6 & 3.38 & 44 & 3.90 & 51 & 161 \\
\hline 178 & 1223.5 & 5.1 & 0.40 & 8 & 1.00 & 20 & 162 \\
\hline 179 & 1228.0 & 4.5 & 1.25 & 28 & 1.40 & 31 & 163 \\
\hline 180 & 1232.9 & 4.9 & 1.24 & 25 & 1.40 & 29 & 163 \\
\hline 181 & 1240.8 & 7.9 & 1.35 & 17 & 2.10 & 27 & 164 \\
\hline 182 & 1248.4 & 7.6 & 0.45 & 6 & 0.70 & 9 & 165 \\
\hline 183 & 1253.4 & 5.0 & 0.00 & 0 & 1.19 & 24 & 166 \\
\hline 184 & 1261.2 & 7.8 & 0.00 & 0 & 0.00 & 0 & 167 \\
\hline 185 & 1269.8 & 8.6 & 0.00 & 0 & 1.41 & 16 & 169 \\
\hline 186 & 1273.0 & 3.2 & 0.78 & 24 & 1.50 & 47 & 170 \\
\hline 187 & 1278.0 & 5.0 & 2.38 & 48 & 2.86 & 57 & 171 \\
\hline 188 & 1284.2 & 6.2 & 1.44 & 23 & 1.44 & 23 & 172 \\
\hline 189 & 1288.9 & 4.7 & 0.40 & 9 & 0.90 & 19 & 173 \\
\hline 190 & 1295.7 & 6.8 & 0.58 & 9 & 1.89 & 28 & 174 \\
\hline 191 & 1297.5 & 1.8 & 0.00 & 0 & 0.46 & 26 & 175 \\
\hline 192 & 1307.8 & 10.3 & 5.10 & 50 & 7.26 & 70 & 175 \\
\hline 193 & 1316.7 & 8.9 & 0.00 & 0 & 0.75 & 8 & 177 \\
\hline 194 & 1322.7 & 6.0 & 1.70 & 28 & 1.70 & 28 & 178 \\
\hline 195 & 1328.9 & 6.2 & 0.90 & 15 & 1.10 & 18 & 179 \\
\hline 196 & 1329.7 & 0.8 & 0.00 & 0 & 0.00 & 0 & 180 \\
\hline 197 & 1336.6 & 6.9 & 1.09 & 16 & 3.08 & 45 & 180 \\
\hline
\end{tabular}


Table D-1: Core-Run RQD Data (Continued)

[Source (DTN): TM0000SD9SUPER.002]

\begin{tabular}{|c|c|c|c|c|c|c|c|}
\hline \multirow[b]{2}{*}{ Run No. } & \multirow{2}{*}{$\begin{array}{c}\text { Interval } \\
\text { Bottom } \\
\text { [feet] }\end{array}$} & \multirow{2}{*}{$\begin{array}{c}\text { Drilled } \\
\text { [feet] }\end{array}$} & \multicolumn{2}{|c|}{ Raw } & \multicolumn{2}{|c|}{ Adjusted } & \multirow{2}{*}{$\begin{array}{c}\text { Page } \\
\text { No. }\end{array}$} \\
\hline & & & $\begin{array}{l}\text { Length } \\
\text { [feet] }^{\dagger}\end{array}$ & RQD $^{\dagger}$ & $\begin{array}{c}\text { Length } \\
\text { [feet] }\end{array}$ & RQD & \\
\hline 198 & 1346.3 & 9.7 & 0.49 & 5 & 0.75 & 8 & 183 \\
\hline 199 & 1348.1 & 1.8 & 0.00 & 0 & 0.80 & 44 & 183 \\
\hline 200 & 1354.0 & 5.9 & 0.85 & 14 & 1.20 & 20 & 184 \\
\hline 201 & 1359.9 & 5.9 & 0.40 & 7 & 0.40 & 7 & 186 \\
\hline 202 & 1363.1 & 3.2 & 0.00 & 0 & 0.00 & 0 & 187 \\
\hline 203 & 1367.3 & 4.2 & 0.40 & 10 & 1.50 & 36 & 188 \\
\hline 204 & 1377.1 & 9.8 & 0.00 & 0 & 2.20 & 22 & 189 \\
\hline 205 & 1384.4 & 7.3 & 1.00 & 14 & 3.20 & 44 & 191 \\
\hline 206 & 1390.5 & 6.1 & 0.00 & 0 & 3.86 & 63 & 193 \\
\hline 207 & 1400.3 & 9.8 & 1.08 & 11 & 3.60 & 37 & 194 \\
\hline 208 & 1409.9 & 9.6 & 1.04 & 11 & 2.68 & 28 & 196 \\
\hline 209 & 1414.2 & 4.3 & 0.40 & 9 & 2.70 & 63 & 198 \\
\hline 210 & 1422.2 & 8.0 & 1.19 & 15 & 1.19 & 15 & 199 \\
\hline 211 & 1430.5 & 8.3 & 3.00 & 36 & 4.81 & 58 & 201 \\
\hline 212 & 1440.1 & 9.6 & 3.27 & 34 & 9.38 & 98 & 202 \\
\hline 213 & 1449.5 & 9.4 & 2.17 & 23 & 9.40 & 100 & 203 \\
\hline 214 & 1459.1 & 9.6 & 8.28 & 86 & 9.90 & 103 & 204 \\
\hline 215 & 1469.0 & 9.9 & 4.40 & 44 & 5.80 & 59 & 205 \\
\hline 216 & 1474.2 & 5.2 & 4.45 & 86 & 5.04 & 97 & 206 \\
\hline 217 & 1479.3 & 5.1 & 3.90 & 76 & 5.30 & 104 & 207 \\
\hline 218 & 1484.2 & 4.9 & 0.40 & 8 & 0.40 & 8 & 207 \\
\hline 219 & 1489.2 & 5.0 & 3.10 & 62 & 3.60 & 72 & 208 \\
\hline 220 & 1490.7 & 1.5 & 0.00 & 0 & 0.00 & 0 & 209 \\
\hline 221 & 1491.7 & 1.0 & 0.00 & 0 & 0.90 & 90 & 209 \\
\hline 222 & 1492.0 & 0.3 & 0.00 & 0 & 0.00 & 0 & 209 \\
\hline 223 & 1497.9 & 5.9 & 3.92 & 66 & 5.40 & 92 & 209 \\
\hline 224 & 1507.2 & 9.3 & 6.79 & 73 & 8.85 & 95 & 210 \\
\hline 225 & 1516.7 & 9.5 & 0.00 & 0 & 0.00 & 0 & 211 \\
\hline 226 & 1526.4 & 9.7 & 6.20 & 64 & 6.92 & 71 & 212 \\
\hline 227 & 1536.6 & 10.2 & 8.60 & 84 & 8.80 & 86 & 214 \\
\hline 228 & 1542.4 & 5.8 & 4.96 & 86 & 5.42 & 93 & 215 \\
\hline 229 & 1547.4 & 5.0 & 4.22 & 84 & 5.00 & 100 & 215 \\
\hline 230 & 1556.9 & 9.5 & 7.01 & 74 & 7.80 & 82 & 216 \\
\hline
\end{tabular}

Table D-1: Core-Run RQD Data (Continued)

[Source (DTN): TM0000SD9SUPER.002]

\begin{tabular}{|c|c|c|c|c|c|c|c|}
\hline \multirow[b]{2}{*}{ Run No. } & \multirow{2}{*}{$\begin{array}{c}\text { Interval } \\
\text { Bottom } \\
\text { [feet] }\end{array}$} & \multirow{2}{*}{$\begin{array}{c}\text { Drilled } \\
\text { [feet] }\end{array}$} & \multicolumn{2}{|c|}{ Raw } & \multicolumn{2}{|c|}{ Adjusted } & \multirow{2}{*}{$\begin{array}{r}\text { Page } \\
\text { No. }\end{array}$} \\
\hline & & & $\begin{array}{l}\text { Length } \\
\text { [feet] }^{\dagger}\end{array}$ & RQD $^{t}$ & $\begin{array}{l}\text { Length } \\
\text { [feet] }\end{array}$ & RQD & \\
\hline 231 & 1566.4 & 9.5 & 6.90 & 73 & 9.70 & 102 & 217 \\
\hline 232 & 1576.1 & 9.7 & 7.77 & 80 & 9.53 & 98 & 218 \\
\hline 233 & 1585.6 & 9.5 & 5.78 & 61 & 8.80 & 93 & 219 \\
\hline 234 & 1595.3 & 9.7 & 3.22 & 33 & 7.58 & 78 & 221 \\
\hline 235 & 1604.8 & 9.5 & 2.69 & 28 & 3.52 & 37 & 222 \\
\hline 236 & 1609.3 & 4.5 & 3.23 & 72 & 3.50 & 78 & 224 \\
\hline 237 & 1616.5 & 7.2 & 4.98 & 69 & 4.98 & 69 & 224 \\
\hline 238 & 1626.1 & 9.6 & 7.41 & 77 & 8.50 & 89 & 225 \\
\hline 239 & 1635.7 & 9.6 & 4.65 & 48 & 6.60 & 69 & 227 \\
\hline 240 & 1645.3 & 9.6 & 9.37 & 98 & 9.43 & 98 & 228 \\
\hline 241 & 1654.8 & 9.5 & 6.30 & 66 & 7.77 & 82 & 228 \\
\hline 242 & 1664.2 & 9.4 & 9.39 & 100 & 9.39 & 100 & 229 \\
\hline 243 & 1671.4 & 7.2 & 7.81 & 108 & 7.81 & 108 & 230 \\
\hline 244 & 1680.8 & 9.4 & 9.55 & 102 & 9.70 & 103 & 231 \\
\hline 245 & 1690.3 & 9.5 & 9.50 & 100 & 9.50 & 100 & 232 \\
\hline 246 & 1700.5 & 10.2 & 9.45 & 93 & 10.20 & 100 & 232 \\
\hline 247 & 1710.2 & 9.7 & 7.80 & 80 & 9.43 & 97 & 233 \\
\hline 248 & 1720.0 & 9.8 & 7.10 & 72 & 8.80 & 90 & 234 \\
\hline 249 & 1729.6 & 9.6 & 9.55 & 99 & 10.03 & 104 & 235 \\
\hline 250 & 1739.2 & 9.6 & 7.99 & 83 & 8.41 & 88 & 235 \\
\hline 251 & 1739.8 & 0.6 & 0.40 & 67 & 0.40 & 67 & 237 \\
\hline 252 & 1749.7 & 9.9 & 9.00 & 91 & 9.43 & 95 & 237 \\
\hline 253 & 1759.0 & 9.3 & 8.30 & 89 & 9.10 & 98 & 238 \\
\hline 254 & 1761.6 & 2.6 & 1.46 & 56 & 2.64 & 102 & 239 \\
\hline 255 & 1771.2 & 9.6 & 8.54 & 89 & 8.86 & 92 & 239 \\
\hline 256 & 1780.7 & 9.5 & 8.68 & 91 & 8.94 & 94 & 240 \\
\hline 257 & 1790.5 & 9.8 & 9.70 & 99 & 9.80 & 100 & 241 \\
\hline 258 & 1800.1 & 9.6 & 9.70 & 101 & 9.73 & 101 & 241 \\
\hline 259 & 1809.7 & 9.6 & 9.60 & 100 & 9.60 & 100 & 242 \\
\hline 260 & 1819.2 & 9.5 & 8.50 & 89 & 9.50 & 100 & 243 \\
\hline 261 & 1828.7 & 9.5 & 3.90 & 41 & 4.60 & 48 & 243 \\
\hline 262 & 1838.0 & 9.3 & 1.43 & 15 & 2.90 & 31 & 244 \\
\hline 263 & 1845.1 & 7.1 & 4.93 & 69 & 6.90 & 97 & 246 \\
\hline
\end{tabular}


Table D-1: Core-Run RQD Data (Continued)

[Source (DTN): TM0000SD9SUPER,002]

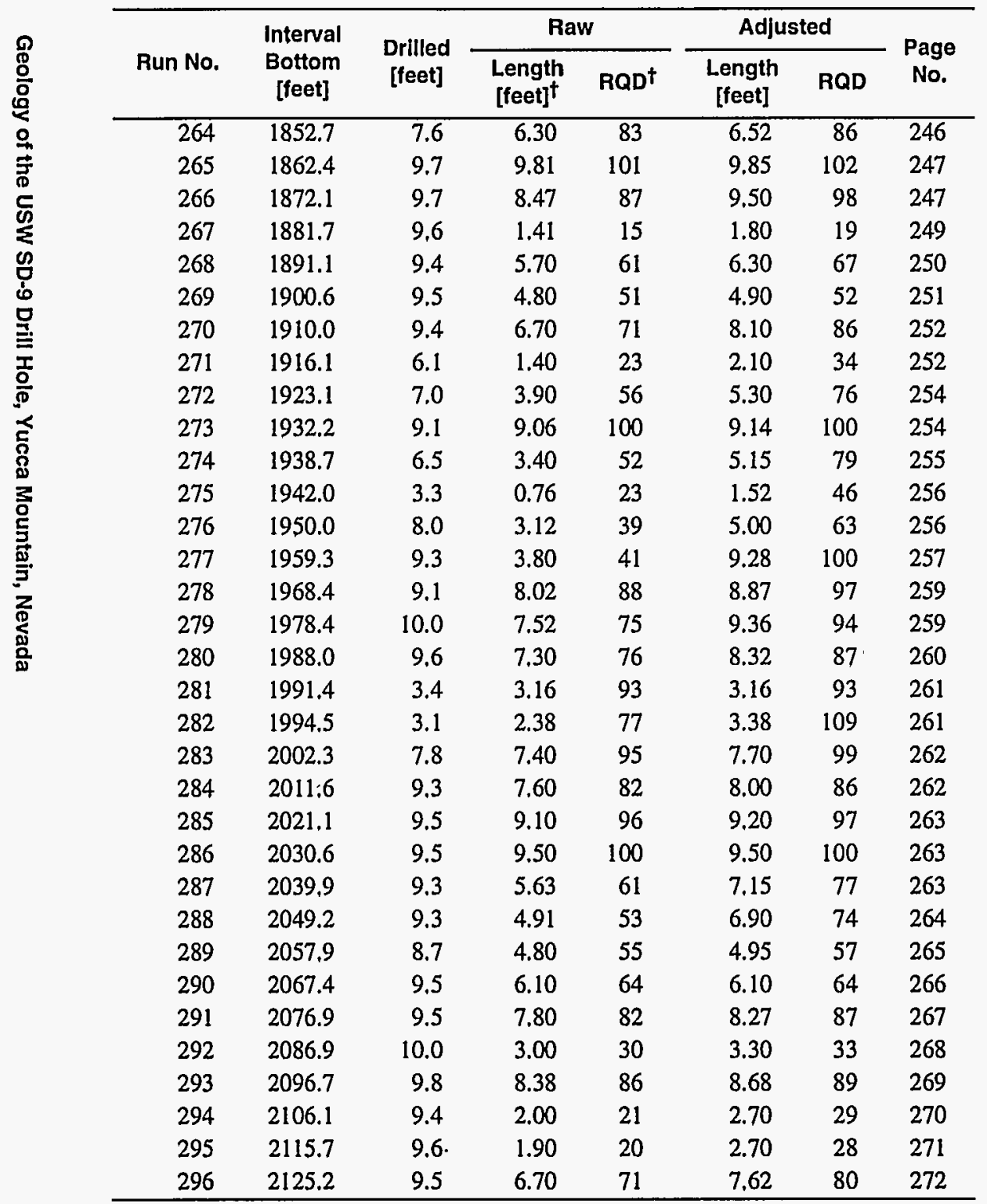

Table D-1: Core-Run RQD Data (Continued)

[Source (DTN): TM0000SD9SUPER.002]

\begin{tabular}{|c|c|c|c|c|c|c|c|}
\hline \multirow[b]{2}{*}{ Run No. } & \multirow{2}{*}{$\begin{array}{c}\text { Interval } \\
\text { Bottom } \\
\text { [feet] }\end{array}$} & \multirow{2}{*}{$\begin{array}{c}\text { Drilled } \\
\text { [feet] }\end{array}$} & \multicolumn{2}{|c|}{ Raw } & \multicolumn{2}{|c|}{ Adjusted } & \multirow{2}{*}{$\begin{array}{c}\text { Page } \\
\text { No. }\end{array}$} \\
\hline & & & $\begin{array}{l}\text { Length } \\
\text { [feet] }^{\dagger}\end{array}$ & RQD' & $\begin{array}{c}\text { Length } \\
\text { [feet] }\end{array}$ & RQD & \\
\hline 297 & 2135.2 & 10.0 & 5.93 & 59 & 9.82 & 98 & 273 \\
\hline 298 & 2141.8 & 6.6 & 1.90 & 29 & 3.10 & 47 & 275 \\
\hline 299 & 2150.7 & 8.9 & 6.95 & 78 & 7.00 & 79 & 276 \\
\hline 300 & 2160.4 & 9.7 & 8.10 & 84 & 9.00 & 93 & 276 \\
\hline 301 & 2169.9 & 9.5 & 9.32 & 98 & 9.32 & 98 & 277 \\
\hline 302 & 2175.0 & 5.1 & 4.30 & 84 & 5.10 & 100 & 277 \\
\hline 303 & 2184.6 & 9.6 & 9.47 & 99 & 9.50 & 99 & 278 \\
\hline 304 & 2194.6 & 10.0 & 9.58 & 96 & 9.62 & 96 & 278 \\
\hline 305 & 2204.3 & 9.7 & 7.15 & 74 & 8.71 & 90 & 279 \\
\hline 306 & 2213.9 & 9.6 & 5.15 & 54 & 8.27 & 86 & 280 \\
\hline 307 & 2223.1 & 9.2 & 9.00 & 98 & 9.14 & 99 & 281 \\
\hline
\end{tabular}

${ }^{\dagger}$ Data for core runs numbered less than $163(1124.4 \mathrm{ft})$ are either missing or incomplete because the technical procedures in place during the time these intervals were drilled did not call for recording raw piece length. 
Table D-2: RQD Values by 10-foot Intervals

[Sources: Drilling Support values computed from table D-1; values for Study 8.3.1.14.2-DTN:. SNF29041993002.069]

\begin{tabular}{|c|c|c|c|c|}
\hline \multirow{2}{*}{$\begin{array}{c}\text { Interval } \\
\text { Bottom } \\
\text { [feet] }\end{array}$} & \multicolumn{2}{|c|}{ Drilling Support } & \multicolumn{2}{|c|}{ Study 8.3.1.14.2 } \\
\hline & $\begin{array}{l}\text { Raw } \\
\text { RQD }\end{array}$ & $\begin{array}{l}\text { Adj. } \\
\text { RQD }\end{array}$ & $\begin{array}{l}\text { Core } \\
\text { RQD }\end{array}$ & $\begin{array}{c}\text { Enhanced } \\
\text { RQD }\end{array}$ \\
\hline 10 & -- & -- & -- & -- \\
\hline 20 & -- & - & -- & -- \\
\hline 30 & -- & -- & -- & -- \\
\hline 40 & -- & -- & -- & -- \\
\hline 50 & - & -- & -- & -- \\
\hline 60 & - & 31 & -- & -- \\
\hline 70 & - & 18 & 11 & 24 \\
\hline 80 & -- & 60 & 64 & 65 \\
\hline 90 & -- & 84 & 67 & 81 \\
\hline 100 & -- & 96 & 69 & 91 \\
\hline 110 & -- & 79 & 73 & 77 \\
\hline 120 & -- & 77 & 28 & 53 \\
\hline 130 & -- & 27 & 2 & 21 \\
\hline 140 & -- & 81 & 60 & 85 \\
\hline 150 & -- & 36 & 19 & 37 \\
\hline 160 & -- & 87 & 79 & 86 \\
\hline 170 & -- & 70 & 35 & 70 \\
\hline 180 & -- & 54 & 21 & 44 \\
\hline 190 & $-\cdot$ & 50 & 0 & 45 \\
\hline 200 & -- & 10 & 0 & 4 \\
\hline 210 & -- & 15 & 7 & 15 \\
\hline 220 & -- & 98 & 99 & 100 \\
\hline 230 & -- & 89 & 55 & 60 \\
\hline 240 & -- & 90 & 67 & 86 \\
\hline 250 & -- & 97 & 94 & 99 \\
\hline 260 & -- & 97 & 91 & 97 \\
\hline 270 & -- & 95 & 77 & 89 \\
\hline 280 & -- & 17 & 0 & 9 \\
\hline 290 & -- & 31 & 5 & 23 \\
\hline 300 & -- & 10 & 6 & 16 \\
\hline 310 & -- & 44 & 40 & 49 \\
\hline 320 & -- & 45 & 41 & 76 \\
\hline
\end{tabular}

Table D-2: RQD Values by 10-foot Intervals (Continued)

[Sources: Drilling Support values computed from table D-1; values for Study 8.3.1.14.2-DTN:. SNF29041993002.069]

\begin{tabular}{|c|c|c|c|c|}
\hline \multirow{2}{*}{$\begin{array}{l}\text { Interval } \\
\text { Bottom } \\
\text { [feet] }\end{array}$} & \multicolumn{2}{|c|}{ Drilling Support } & \multicolumn{2}{|c|}{ Study 8.3.1.14.2 } \\
\hline & $\begin{array}{l}\text { Raw } \\
\text { RQD }\end{array}$ & $\begin{array}{l}\text { Adl. } \\
\text { RQD }\end{array}$ & $\begin{array}{l}\text { Core } \\
\text { RQD }\end{array}$ & $\begin{array}{c}\text { Enhanced } \\
\text { RQD }\end{array}$ \\
\hline 330 & -- & 78 & 51 & 84 \\
\hline 340 & -- & 85 & 38 & 66 \\
\hline 350 & -- & 77 & 29 & 83 \\
\hline 360 & -- & 44 & 10 & 41 \\
\hline 370 & - & 37 & 7 & 27 \\
\hline 380 & - & 51 & 4 & 44 \\
\hline 390 & -- & 41 & 9 & 30 \\
\hline 400 & -- & 69 & 7 & 66 \\
\hline 410 & -- & 60 & 19 & 74 \\
\hline 420 & -- & 2 & 12 & 68 \\
\hline 430 & -- & 32 & 38 & 77 \\
\hline 440 & -- & 54 & 36 & 77 \\
\hline 450 & -- & 25 & 5 & 17 \\
\hline 460 & - & 82 & 63 & 79 \\
\hline 470 & -- & 22 & 19 & 32 \\
\hline 480 & -- & 35 & 3 & 13 \\
\hline 490 & -- & 13 & 0 & 0 \\
\hline 500 & -- & 29 & 1 & 39 \\
\hline 510 & -- & 13 & 5 & 5 \\
\hline 520 & -- & 79 & 39 & 68 \\
\hline 530 & -- & 47 & 16 & 43 \\
\hline 540 & -- & 39 & 20 & 38 \\
\hline 550 & -. & 14 & 4 & 7 \\
\hline 560 & -- & 44 & 20 & 36 \\
\hline 570 & -- & 5 & 4 & 10 \\
\hline 580 & -- & 24 & 18 & 22 \\
\hline 590 & -- & 51 & 5 & 45 \\
\hline 600 & - & 52 & 8 & 60 \\
\hline 610 & -- & 53 & 14 & 52 \\
\hline 620 & -- & 31 & 4 & 19 \\
\hline 630 & -- & 17 & 3 & 26 \\
\hline 640 & -- & 44 & 22 & 36 \\
\hline
\end{tabular}


Table D-2: RQD Values by 10-foot Intervals (Continued)

[Sources: Drilling Support values computed from table D-1; values for Study 8.3.1.14.2-DTN:. SNF29041993002.069]

\begin{tabular}{|c|c|c|c|c|}
\hline \multirow{2}{*}{$\begin{array}{c}\text { Interval } \\
\text { Bottom } \\
\text { [feet] }\end{array}$} & \multicolumn{2}{|c|}{ Drilling Support } & \multicolumn{2}{|c|}{ Study 8.3.1.14.2 } \\
\hline & $\begin{array}{l}\text { Raw } \\
\text { RQD }\end{array}$ & $\begin{array}{l}\text { Ad]. } \\
\text { RQD }\end{array}$ & $\begin{array}{l}\text { Core } \\
\text { RQD }\end{array}$ & $\begin{array}{c}\text { Enhanced } \\
\text { RQD }\end{array}$ \\
\hline 650 & $\cdots$ & 15 & 3 & 5 \\
\hline 660 & -- & 26 & 7 & 34 \\
\hline 670 & -- & 50 & 4 & 31 \\
\hline 680 & -- & 55 & 14 & 62 \\
\hline 690 & -- & 62 & 19 & 55 \\
\hline 700 & $\cdots$ & 57 & 6 & 39 \\
\hline 710 & - & 73 & 9 & 76 \\
\hline 720 & -- & 73 & 16 & 54 \\
\hline 730 & - & 74 & 41 & 60 \\
\hline 740 & - & 73 & 28 & 56 \\
\hline 750 & -- & 20 & 7 & 17 \\
\hline 760 & - & 30 & 12 & 32 \\
\hline 770 & -- & 68 & 62 & 72 \\
\hline 780 & -- & 75 & 64 & 72 \\
\hline 790 & -- & 4 & 0 & 0 \\
\hline 800 & -- & 41 & 8 & 31 \\
\hline 810 & -- & 45 & 19 & 50 \\
\hline 820 & -- & 73 & 52 & 63 \\
\hline 830 & $\cdots$ & 84 & 48 & 60 \\
\hline 840 & -. & 86 & 78 & 92 \\
\hline 850 & -- & 89 & 18 & 39 \\
\hline 860 & -- & 46 & 16 & 49 \\
\hline 870 & -- & 16 & 0 & 8 \\
\hline 880 & 0 & 11 & 5 & 7 \\
\hline 890 & 0 & 8 & 0 & 0 \\
\hline 900 & 0 & 14 & 3 & 6 \\
\hline 910 & 0 & 43 & 4 & 18 \\
\hline 920 & 0 & 2 & 0 & 0 \\
\hline 930 & 0 & 19 & 1 & 1 \\
\hline 940 & 0 & 21 & 3 & 22 \\
\hline 950 & 2 & 39 & 8 & 34 \\
\hline 260 & 6 & 16 & 4 & 15 \\
\hline
\end{tabular}

Table D-2: RQD Values by 10-foot Intervals (Continued)

[Sources: Drilling Support values computed from table D-1; values for Study 8.3.1.14.2 -DTN:. SNF29041993002.069]

\begin{tabular}{|c|c|c|c|c|}
\hline \multirow{2}{*}{$\begin{array}{c}\text { Interval } \\
\text { Bottom } \\
\text { [feet] }\end{array}$} & \multicolumn{2}{|c|}{ Drilling Support } & \multicolumn{2}{|c|}{ Study 8.3.1.14.2 } \\
\hline & $\begin{array}{l}\text { Raw } \\
\text { RQD }\end{array}$ & $\begin{array}{l}\text { Adj. } \\
\text { RQD }\end{array}$ & $\begin{array}{l}\text { Core } \\
\text { RQD }\end{array}$ & $\begin{array}{c}\text { Enhanced } \\
\text { RQD }\end{array}$ \\
\hline 970 & 14 & 22 & 10 & 22 \\
\hline 980 & 0 & 15 & 0 & 4 \\
\hline 990 & 1 & 29 & 0 & 22 \\
\hline 1000 & 12 & 37 & 11 & 48 \\
\hline 1010 & 2 & 22 & 0 & 16 \\
\hline 1020 & 7 & 26 & 4 & 14 \\
\hline 1030 & 0 & 21 & 2 & 17 \\
\hline 1040 & 0 & 75 & 30 & 67 \\
\hline 1050 & 0 & 76 & 49 & 53 \\
\hline 1060 & 20 & 44 & 20 & 32 \\
\hline 1070 & 15 & 49 & 15 & 61 \\
\hline 1080 & 7 & 22 & 5 & 9 \\
\hline 1090 & 12 & 27 & 0 & 0 \\
\hline 1100 & 32 & 42 & 18 & 34 \\
\hline 1110 & 59 & 70 & 41 & 71 \\
\hline 1120 & 53 & 65 & 49 & 67 \\
\hline 1130 & 31 & 48 & 34 & 59 \\
\hline 1140 & 14 & 24 & 16 & 18 \\
\hline 1150 & 41 & 50 & 38 & 53 \\
\hline 1160 & 24 & 35 & 13 & 37 \\
\hline 1170 & 31 & 68 & 33 & 69 \\
\hline 1180 & 13 & 25 & 12 & 33 \\
\hline 1190 & 17 & 28 & 0 & 20 \\
\hline 1200 & 16 & 31 & 9 & 40 \\
\hline 1210 & 16 & 20 & 19 & 23 \\
\hline 1220 & 37 & 44 & 32 & 38 \\
\hline 1230 & 20 & 27 & 8 & 21 \\
\hline 1240 & 19 & 27 & 8 & 19 \\
\hline 1250 & 6 & 13 & 5 & 11 \\
\hline 1260 & 0 & 8 & 4 & 32 \\
\hline $1270^{\circ}$ & 1 & 15 & 0 & 20 \\
\hline 1280 & 43 & 41 & 24 & 27 \\
\hline
\end{tabular}


Table D-2: RQD Values by 10-foot Intervals (Continued)

[Sources: Drilling Support values computed from table D-1; values for Study 8.3.1.14.2-DTN:. SNF29041993002.069]

\begin{tabular}{|c|c|c|c|c|}
\hline \multirow{2}{*}{$\begin{array}{c}\text { Interval } \\
\text { Bottom } \\
\text { [feet] }\end{array}$} & \multicolumn{2}{|c|}{ Drilling Support } & \multicolumn{2}{|c|}{ Study 8.3.1.14.2 } \\
\hline & $\begin{array}{l}\text { Raw } \\
\text { RQD }\end{array}$ & $\begin{array}{l}\text { Ad]. } \\
\text { RQD }\end{array}$ & $\begin{array}{l}\text { Core } \\
\text { RQD }\end{array}$ & $\begin{array}{c}\text { Enhanced } \\
\text { RQD }\end{array}$ \\
\hline 1290 & 15 & 22 & 15 & 16 \\
\hline 1300 & 17 & 38 & 14 & 32 \\
\hline 1310 & 39 & 57 & 21 & 47 \\
\hline 1320 & 9 & 15 & 16 & 24 \\
\hline 1330 & 17 & 20 & 5 & 17 \\
\hline 1340 & 12 & 32 & 14 & 45 \\
\hline 1350 & 6 & 17 & 0 & 0 \\
\hline 1360 & 10 & 12 & -- & -- \\
\hline 1370 & 4 & 21 & -- & - \\
\hline 1380 & 4 & 29 & -- & - \\
\hline 1390 & 6 & 55 & -- & -- \\
\hline 1400 & 10 & 38 & -- & -- \\
\hline 1410 & 11 & 29 & -- & -- \\
\hline 1420 & 13 & 35 & -- & -- \\
\hline 1430 & 31 & 48 & -- & -- \\
\hline 1440 & 34 & 96 & -- & -- \\
\hline 1450 & 22 & 100 & - & -- \\
\hline 1460 & 4 & 99 & -- & - \\
\hline 1470 & 49 & 62 & -- & - \\
\hline 1480 & 76 & 94 & -- & - \\
\hline 1490 & 34 & 39 & -. & -- \\
\hline 1500 & 55 & 83 & -- & -- \\
\hline 1510 & 53 & 69 & -- & -- \\
\hline 1520 & 21 & 24 & -- & - \\
\hline 1530 & 71 & 77 & -. & -- \\
\hline 1540 & 85 & 89 & -- & -- \\
\hline 1550 & 82 & 94 & -- & -- \\
\hline 1560 & 73 & 88 & -- & -- \\
\hline 1570 & 75 & 101 & -- & - \\
\hline 1580 & 73 & 96 & -- & - \\
\hline 1590 & 49 & 86 & -- & -- \\
\hline 1600 & 31 & 59 & -- & -- \\
\hline
\end{tabular}

Table D-2: RQD Values by 10-foot Intervals (Continued)

[Sources: Drilling Support values computed from table D-1; values for Study 8.3.1.14.2-DTN:. SNF29041993002.069]

\begin{tabular}{|c|c|c|c|c|}
\hline \multirow{2}{*}{$\begin{array}{c}\text { Interval } \\
\text { Bottom } \\
\text { [feet] }\end{array}$} & \multicolumn{2}{|c|}{ Drilling Support } & \multicolumn{2}{|c|}{ Study 8.3.1.14.2 } \\
\hline & $\begin{array}{l}\text { Raw } \\
\text { RQD }\end{array}$ & $\begin{array}{l}\text { Adj. } \\
\text { RQD }\end{array}$ & $\begin{array}{l}\text { Core } \\
\text { RQD }\end{array}$ & $\begin{array}{c}\text { Enhanced } \\
\text { RQD }\end{array}$ \\
\hline 1610 & 51 & 58 & - & -- \\
\hline 1620 & 72 & 76 & -- & -- \\
\hline 1630 & 66 & 81 & -- & -- \\
\hline 1640 & 70 & 81 & -- & -- \\
\hline 1650 & 83 & 91 & -- & -- \\
\hline 1660 & 84 & 91 & -- & -- \\
\hline 1670 & 105 & 105 & -- & -- \\
\hline 1680 & 103 & 104 & - & -- \\
\hline 1690 & 100 & 100 & -- & - \\
\hline 1700 & 93 & 100 & -- & -- \\
\hline 1710 & 81 & 97 & -- & -- \\
\hline 1720 & 73 & 90 & -- & -- \\
\hline 1730 & 104 & 99 & -- & -- \\
\hline 1740 & 82 & 87 & -- & -- \\
\hline 1750 & 91 & 95 & -- & -- \\
\hline 1760 & 86 & 98 & -- & -- \\
\hline 1770 & 84 & 94 & -- & - \\
\hline 1780 & 91 & 94 & -- & -- \\
\hline 1790 & 98 & 100 & -- & -- \\
\hline 1800 & 101 & 101 & -- & -- \\
\hline 1810 & 100 & 100 & -- & -- \\
\hline 1820 & 86 & 96 & -- & -- \\
\hline$\cdot 1830$ & 38 & 46 & - & -- \\
\hline 1840 & 26 & 44 & -- & -- \\
\hline 1850 & 76 & 92 & -- & -- \\
\hline 1860 & 96 & 97 & -- & -- \\
\hline 1870 & 91 & 99 & -- & -- \\
\hline 1880 & 30 & 35 & -- & -- \\
\hline 1890 & 53 & 59 & -- & -- \\
\hline 1900 & 52 & 53 & - & -- \\
\hline 1910 & 70 & 84 & -- & -- \\
\hline 1920 & 36 & 51 & -- & -- \\
\hline
\end{tabular}


Table D-2: RQD Values by 10-foot Intervals (Continued)

[Sources: Drilling Support values computed from table D-1; values for Study 8.3.1.14.2-DTN:. SNF29041993002.069]

\begin{tabular}{|c|c|c|c|c|}
\hline \multirow{2}{*}{$\begin{array}{c}\text { Interval } \\
\text { Bottom } \\
\text { [feet] }\end{array}$} & \multicolumn{2}{|c|}{ Drilling Support } & \multicolumn{2}{|c|}{ Study 8.3.1.14.2 } \\
\hline & $\begin{array}{l}\text { Raw } \\
\text { RQD }\end{array}$ & $\begin{array}{l}\text { Adj. } \\
\text { RQD }\end{array}$ & $\begin{array}{l}\text { Core } \\
\text { RQD }\end{array}$ & $\begin{array}{c}\text { Enhanced } \\
\text { RQD }\end{array}$ \\
\hline 1930 & 86 & 93 & -- & -- \\
\hline 1940 & 59 & 80 & .- & .- \\
\hline 1950 & 36 & 59 & .- & -- \\
\hline 1960 & 44 & 100 & -- & -- \\
\hline 1970 & 86 & 97 & -. & -- \\
\hline 1980 & 75 & 92 & -- & -- \\
\hline 1990 & 79 & 88 & -- & -- \\
\hline 2000 & 89 & 101 & -- & .- \\
\hline 2010 & 85 & 89 & -- & -- \\
\hline 2020 & 94 & 95 & -- & -- \\
\hline 2030 & 100 & 100 & .. & -. \\
\hline 2040 & 63 & 78 & -- & -. \\
\hline 2050 & 53 & 73 & -. & -- \\
\hline 2060 & 57 & 58 & -- & -- \\
\hline 2070 & 69 & 70 & -- & -- \\
\hline 2080 & 66 & 70 & .- & -- \\
\hline 2090 & 47 & 50 & -- & -- \\
\hline 2100 & 64 & 69 & -- & -- \\
\hline 2110 & 21 & 28 & -- & -- \\
\hline 2120 & 42 & 51 & -. & -. \\
\hline 2130 & 65 & 89 & -- & -- \\
\hline 2140 & 45 & 74 & -- & -- \\
\hline 2150 & 69 & 73 & -- & -- \\
\hline 2160 & 83 & 92 & -- & -- \\
\hline 2170 & 97 & 98 & -- & -- \\
\hline 2180 & 91 & 99 & -- & -- \\
\hline 2190 & 97 & 97 & -- & -- \\
\hline 2200 & 84 & 93 & -- & -- \\
\hline 2210 & 62 & 88 & -- & -- \\
\hline 2220 & 81 & 94 & -- & -- \\
\hline 2230 & 30 & 31 & -- & -- \\
\hline
\end{tabular}


Appendix E: Lithophysal Cavity Data 
Table E-1: Measured Lithophysal Cavity Abundances for 10-foot Composite Intervals [NM - not meaningful; <- less than. Source: DTN SNF29041993002.069]

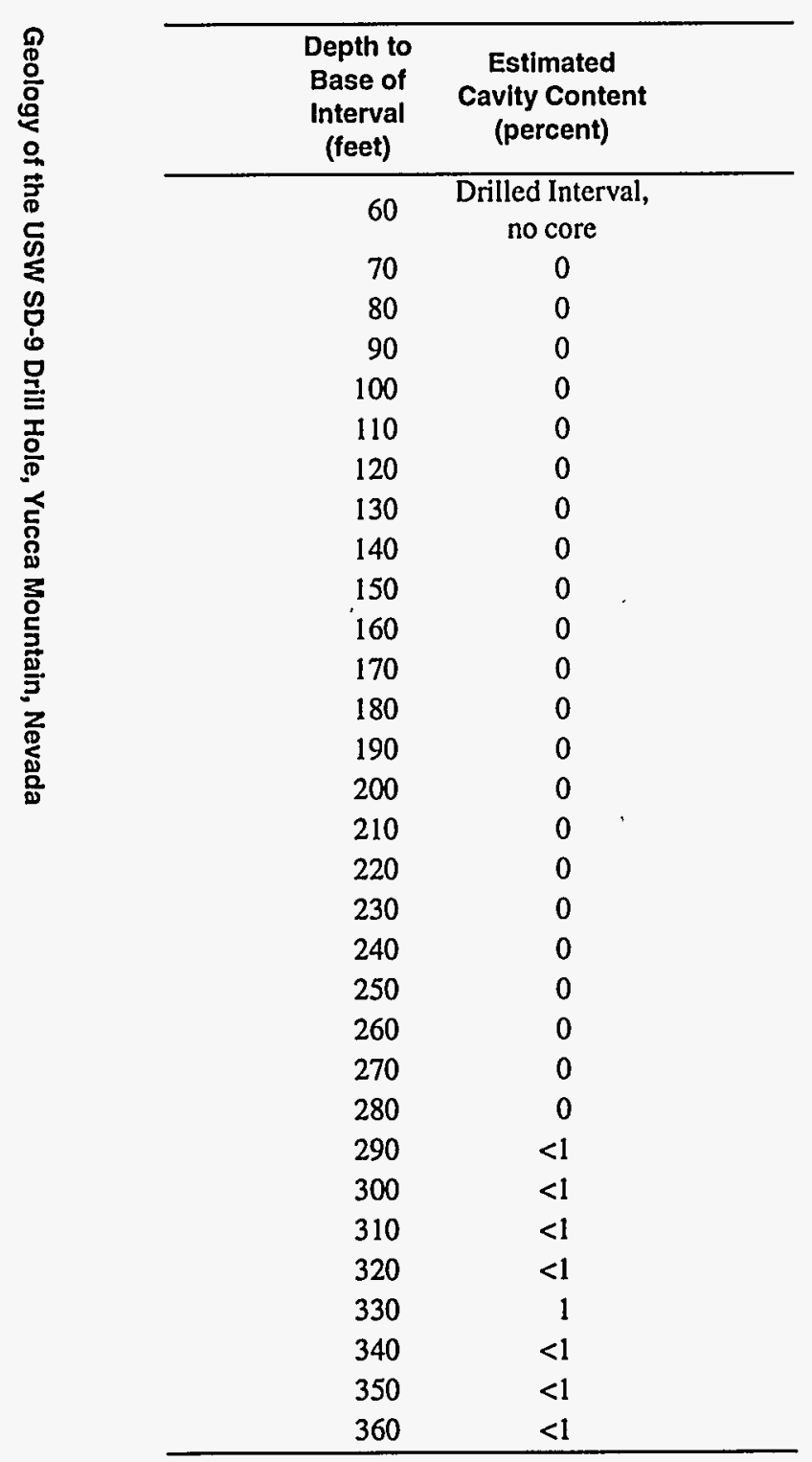

\begin{tabular}{|c|c|}
\hline $\begin{array}{l}\text { Depth to } \\
\text { Base of } \\
\text { Interval } \\
\text { (feet) }\end{array}$ & $\begin{array}{l}\text { Estimated } \\
\text { Cavity Content } \\
\text { (percent) }\end{array}$ \\
\hline 370 & $<1$ \\
\hline 380 & $<1$ \\
\hline 390 & $<1$ \\
\hline 400 & $<1$ \\
\hline 410 & $<1$ \\
\hline 420 & $<1$ \\
\hline 430 & $<1$ \\
\hline 440 & $<1$ \\
\hline 450 & $<1$ \\
\hline 460 & 3 \\
\hline 470 & 2 \\
\hline 480 & 2 \\
\hline 490 & NM \\
\hline 500 & 3 \\
\hline 510 & 3 \\
\hline 520 & 10 \\
\hline 530 & 5 \\
\hline 540 & 5 \\
\hline 550 & 12 \\
\hline 560 & 5 \\
\hline 570 & 13 \\
\hline 580 & 11 \\
\hline 590 & 12 \\
\hline 600 & 9 \\
\hline 610 & 9 \\
\hline 620 & 6 \\
\hline 630 & 3 \\
\hline 640 & 3 \\
\hline 650 & 2 \\
\hline 660 & 1 \\
\hline 670 & 1 \\
\hline 680 & 2 \\
\hline
\end{tabular}

\begin{tabular}{|c|c|}
\hline $\begin{array}{c}\text { Depth to } \\
\text { Base of } \\
\text { Interval } \\
\text { (feet) }\end{array}$ & $\begin{array}{l}\text { Estimated } \\
\text { Cavity Content } \\
\text { (percent) }\end{array}$ \\
\hline 690 & 2 \\
\hline 700 & 2 \\
\hline 710 & 2 \\
\hline 720 & 1 \\
\hline 730 & 1 \\
\hline 740 & 1 \\
\hline 750 & $<1$ \\
\hline 760 & $<1$ \\
\hline 770 & 1 \\
\hline 780 & 1 \\
\hline 790 & NM \\
\hline 800 & 2 \\
\hline 810 & 1 \\
\hline 820 & $<1$ \\
\hline 830 & $<1$ \\
\hline 840 & $<1$ \\
\hline 850 & $<1$ \\
\hline 860 & $<1$ \\
\hline 870 & $<1$ \\
\hline 880 & $<1$ \\
\hline 890 & NM \\
\hline 900 & NM \\
\hline 910 & NM \\
\hline 920 & NM \\
\hline 930 & $<1$ \\
\hline 940 & $<1$ \\
\hline 950 & $<1$ \\
\hline 960 & 1 \\
\hline 970 & 3 \\
\hline 980 & 5 \\
\hline 990 & 2 \\
\hline 1000 & 2 \\
\hline
\end{tabular}


Table E-1: Measured Lithophysal Cavity Abundances for 10-foot Composite Intervals (Continued) [NM - not meaningful; <- less than. Source: DTN SNF29041993002.069]

\begin{tabular}{|c|c|c|}
\hline & $\begin{array}{l}\text { Depth to } \\
\text { Base of } \\
\text { Interval } \\
\text { (feet) }\end{array}$ & $\begin{array}{l}\text { Estimated } \\
\text { Cavity Content } \\
\text { (percent) }\end{array}$ \\
\hline & 1010 & 1 \\
\hline & 1020 & NM \\
\hline & 1030 & $<1$ \\
\hline & 1040 & $<1$ \\
\hline & 1050 & 1 \\
\hline & 1060 & $<1$ \\
\hline & 1070 & 1 \\
\hline & 1080 & $<1$ \\
\hline & 1090 & 0 \\
\hline & 1100 & $<1$ \\
\hline & 1110 & 1 \\
\hline & 1120 & 2 \\
\hline & 1130 & 1 \\
\hline & 1140 & 1 \\
\hline & 1150 & $<1$ \\
\hline & 1160 & $<1$ \\
\hline & 1170 & $<1$ \\
\hline & 1180 & $<1$ \\
\hline ty & 1190 & $<1$ \\
\hline & 1200 & $<1$ \\
\hline & 1210 & $<1$ \\
\hline & 1220 & $<1$ \\
\hline & 1230 & $<1$ \\
\hline & 1240 & $<1$ \\
\hline & 1250 & $<1$ \\
\hline & 1260 & $<1$ \\
\hline & 1270 & $<1$ \\
\hline & 1280 & $<1$ \\
\hline & 1290 & $<1$ \\
\hline & 1300 & $<1$ \\
\hline & 1310 & $<1$ \\
\hline & 1320 & $<1$ \\
\hline
\end{tabular}

\begin{tabular}{cc}
\hline $\begin{array}{c}\text { Depth to } \\
\text { Base of } \\
\text { Interval } \\
\text { (feet) }\end{array}$ & $\begin{array}{c}\text { Estimated } \\
\text { Cavity Content } \\
\text { (percent) }\end{array}$ \\
\hline 1330 & $<1$ \\
1340 & $<1$ \\
1350 & $<1$ \\
\hline
\end{tabular}


This page intentionally left blank. 


\section{Appendix F: Fracture Information}


Table F-1: Measured Fracture Data for 10-foot Composite Intervals

[N-natural, I-indeterminate, C-coring-induced, V-vug or void; dip classes are 10-degree intervals ending with the indicated value. Source: DTN SNF29041993002.069]

\begin{tabular}{|c|c|c|c|c|c|c|c|c|c|c|c|c|c|c|c|}
\hline \multirow{2}{*}{$\begin{array}{l}\text { Depth to } \\
\text { Base of } \\
\text { Interval } \\
\text { (feet) }\end{array}$} & \multicolumn{4}{|c|}{ Type of Fracture } & \multicolumn{9}{|c|}{ Dip of Fracture (degrees) } & \multirow{2}{*}{$\begin{array}{l}\text { Lost } \\
\text { Core } \\
\text { (feet) }\end{array}$} & \multirow{2}{*}{$\begin{array}{c}\text { Rubble } \\
\text { (feet) }\end{array}$} \\
\hline & N & 1 & c & $v$ & 10 & 20 & 30 & 40 & 50 & 60 & 70 & 80 & 90 & & \\
\hline 60 & \multicolumn{13}{|c|}{ Drilled Interval, No Core } & 0.2 & 1.1 \\
\hline 70 & 52 & 2 & 2 & -- & 32 & 9 & 7 & 3 & -- & -- & -- & -- & 3 & 0.0 & 0.1 \\
\hline 80 & 11 & 10 & 2 & - & 8 & 4 & 3 & 1 & 1 & 2 & -- & -- & 2 & 0.2 & 0.2 \\
\hline 90 & 3 & 12 & 10 & -- & 10 & 2 & -- & -- & 1 & & -- & -- & 2 & 0.4 & 0.5 \\
\hline 100 & 1 & 1 & 10 & - & 1 & -- & -- & -- & -- & 1 & -- & -- & -- & 0.0 & - \\
\hline 110 & 4 & 5 & 11 & -- & 4 & -- & 2 & 2 & -- & -- & -- & -- & 1 & 0.0 & -- \\
\hline 120 & 3 & 6 & 22 & -- & 4 & 1 & 1 & -- & -- & -- & -- & 1 & 2 & 4.2 & 1.4 \\
\hline 130 & 1 & 17 & 8 & -- & 8 & 3 & 3 & -- & -- & 3 & -- & 1 & -- & 1.5 & -- \\
\hline 140 & 1 & -- & 18 & -- & -- & -- & -- & -- & -- & -- & -- & 1 & -- & 6.3 & -. \\
\hline 150 & -- & -- & 13 & -- & -- & -- & -- & -- & -- & -. & -- & -- & -- & 1.1 & 0.3 \\
\hline 160 & -- & -- & 12 & -- & .- & -- & -- & -- & -- & -- & .. & -- & -- & 2.8 & 0.2 \\
\hline 170 & -- & 2 & 21 & -- & -- & -- & -- & .- & -- & -- & -- & -- & 2 & 3.7 & -- \\
\hline 180 & -- & 12 & 8 & - & 11 & -- & -- & -- & -- & -- & -- & 1 & -- & 5.3 & -- \\
\hline 190 & -. & 1 & 19 & -- & 1 & -- & -. & -. & -- & -- & -- & -- & -- & 9.6 & -- \\
\hline 200 & -- & -- & 2 & -- & -- & -- & -- & -- & -- & -- & -. & -- & -- & 8.5 & -- \\
\hline 210 & -- & -- & 5 & -- & .. & -- & -- & -- & -- & -- & -. & -- & -- & 0.0 & -- \\
\hline 220 & -- & -- & 13 & -- & -- & -- & -- & -- & -- & -- & -- & -- & -- & 1.0 & -- \\
\hline 230 & -- & 18 & 10 & -- & 18 & -- & -- & -- & -- & -- & -- & -- & - & 0.9 & 0.3 \\
\hline 240 & -- & 3 & 11 & -- & 3 & -- & -- & -. & -- & -- & -- & -- & -- & 0.0 & 0.1 \\
\hline 250 & .. & -- & 8 & -- & -- & .- & -- & -- & -- & -- & -- & -- & -- & 0.1 & 0.2 \\
\hline 260 & -- & -- & 6 & -- & -- & -- & -- & -- & -- & -- & -- & -- & -- & 0.2 & 0.6 \\
\hline 270 & -. & 2 & 11 & -- & 2 & -- & -- & -- & -- & -- & -- & -- & -- & 2.3 & 2.0 \\
\hline 280 & 41 & 5 & 7 & -- & 34 & 4 & 3 & -. & 1 & 1 & -- & 1 & 2 & 0.9 & 3.6 \\
\hline 290 & 15 & 9 & 16 & - & 10 & 6 & 3 & 1 & -- & 1 & -- & 2 & 1 & 4.0 & 2.0 \\
\hline 300 & 12 & 6 & 5 & -- & 11 & -- & 1 & 1 & -- & -- & -- & 2 & 3 & 3.1 & 1.1 \\
\hline 310 & 2 & 12 & 6 & -. & 7 & 3 & 1 & -- & 1 & 1 & -- & 1 & -- & 1.1 & 0.6 \\
\hline 320 & 9 & 4 & 20 & -- & 8 & 3 & 1 & -- & 1 & -- & -- & -- & -- & 0.7 & 0.1 \\
\hline 330 & 3 & -- & 20 & -- & 2 & -- & -- & -. & -- & -- & -- & -- & 1 & 1.0 & 1.0 \\
\hline 340 & -- & 2 & 23 & -- & -- & -- & -- & -- & -- & -- & -- & 1 & 1 & 0.6 & 0.5 \\
\hline 350 & -- & 2 & 36 & -. & -- & -- & -- & -- & 1 & -- & -- & 1 & -- & 2.8 & 1.9 \\
\hline 360 & 1 & 4 & 26 & -. & 2 & -- & -- & -- & -- & -- & -- & 3 & -- & 4.0 & 1.4 \\
\hline 370 & .- & 4 & 23 & -- & -- & -. & -- & -- & -- & 1 & 1 & -- & 2 & 2.9 & 1.7 \\
\hline 380 & 1 & 4 & 28 & -- & -- & 1 & -- & -- & .- & -- & -- & 1 & 3 & 1.9 & 4.7 \\
\hline 390 & -- & -- & 19 & -- & -- & .- & -- & -- & -- & -- & -- & -- & -- & 3.4 & -- \\
\hline 400 & -- & -- & 27 & .. & -- & -- & -- & -- & -- & -- & -- & -- & -- & 0.9 & 1.1 \\
\hline 410 & -- & 1 & 37 & - & -- & 1 & -- & -- & -- & -- & -- & -- & -- & 2.1 & 0.2 \\
\hline 420 & 1 & 1 & 35 & -- & 1 & -- & -- & -- & -- & -- & -- & -- & 1 & 0.9 & 1.2 \\
\hline 430 & 2 & 3 & 26 & -- & 2 & -- & 1 & -- & 1 & -- & -- & -- & 1 & 0.9 & 0.7 \\
\hline 440 & 2 & 2 & 28 & -- & 2 & -. & -- & -- & -- & 2 & -- & -- & -- & 5.4 & 1.7 \\
\hline 450 & 1 & 3 & 14 & -- & -- & -- & -- & -- & -- & -- & -- & 2 & 2 & 1.1 & 0.8 \\
\hline 460 & -- & 1 & 17 & -- & -- & -- & -- & - & -- & -- & -- & -- & 1 & 3.1 & 3.7 \\
\hline 470 & - & -- & 15 & -- & -- & -- & -- & -- & -- & -- & - & -- & -- & 4.3 & 3.3 \\
\hline 480 & 1 & 1 & 12 & -- & -- & -- & 1 & - & -- & -- & -- & -- & 1 & 8.1 & 1.7 \\
\hline 490 & -- & -- & 2 & -- & -- & -- & -- & -- & -- & -- & -- & -- & -- & 3.2 & 2.6 \\
\hline 500 & - & 1 & 20 & -- & 1 & -- & -- & -- & -- & -- & -- & -- & -- & 6.6 & 2.9 \\
\hline 510 & -- & -- & 1 & -- & -- & -- & -- & -- & -- & -- & -- & -- & -- & 1.9 & 0.8 \\
\hline 520 & -- & 1 & 23 & -- & -- & -- & -- & -- & -. & -- & -- & -- & 1 & 4.2 & 1.5 \\
\hline
\end{tabular}


Table F-1: Measured Fracture Data for 10-foot Composite Intervals (Continued)

[N-natural, I-indeterminate, $\mathrm{C}$-coring-induced, $\mathrm{V}$-vug or void; dip classes are 10-degree intervals ending with the indicated value. Source: DTN SNF29041993002.069]

\begin{tabular}{|c|c|c|c|c|c|c|c|c|c|c|c|c|c|c|c|}
\hline \multirow{2}{*}{$\begin{array}{l}\text { Depth to } \\
\text { Base of } \\
\text { Interval } \\
\text { (feet) }\end{array}$} & \multicolumn{4}{|c|}{ Type of Fracture } & \multicolumn{9}{|c|}{ Dip of Fracture (degrees) } & \multirow{2}{*}{$\begin{array}{l}\text { Lost } \\
\text { Core } \\
\text { (feet) }\end{array}$} & \multirow{2}{*}{$\begin{array}{c}\text { Rubble } \\
\text { (feet) }\end{array}$} \\
\hline & $\mathbf{N}$ & $\mathbf{I}$ & c & $\mathbf{v}$ & 10 & 20 & 30 & 40 & 50 & 60 & 70 & 80 & 90 & & \\
\hline 530 & -- & -- & 19 & -- & -- & -- & -- & - & -- & -- & -- & - & -- & 4.4 & 1.1 \\
\hline 540 & -- & 2 & 16 & -- & -- & -- & -- & -- & -- & -- & -- & -- & 2 & 5.5 & 3.8 \\
\hline 550 & -- & -- & 2 & -- & -- & - & -- & -- & -- & -- & -- & -- & -. & 2.9 & 2.1 \\
\hline 560 & -- & 3 & 16 & -- & -- & -- & -- & -- & -- & -- & -- & -- & 3 & 6.3 & 2.5 \\
\hline 570 & -- & -- & 9 & -- & -- &.- & -- & -- & -- & -- & -- & -- & -. & 5.0 & 2.5 \\
\hline 580 & -- & -- & 10 & -- & -- & -- & -- & -- & -- & -- & -- & - & -- & 3.5 & 1.4 \\
\hline 590 & -- & 1 & 22 & -. & 1 & -- & -- & - & -- & -- & -- & -- & -- & 2.8 & 1.1 \\
\hline 600 & -- & 1 & 26 & -- & - & -- & -- & -. & -- & -- & -- & -- & 1 & 2.2 & 2.4 \\
\hline 610 & - & -- & 26 & -- & - & -- & -. & -- & -- & -- & -- & -- & -- & 5.5 & 2.4 \\
\hline 620 & -- & -- & 13 & -- & -- & -- & -- & -- & .. & -- & -- & -- & -- & 6.9 & 0.3 \\
\hline 630 & -- & 2 & 13 & 2 & -- & -- & -- & -- & 1 & -- & -- & - & 1 & 4.5 & 1.7 \\
\hline 640 & -- & 2 & 16 & -- & 1 & -- & -- & -- & -. & -- & -- & -. & 1 & 7.1 & 1.9 \\
\hline 650 & -- & 3 & 1 & -- & 2 & - & -- & -- & -. & -- & 1 & -. & -- & 3.9 & 2.4 \\
\hline 660 & -- & 3 & 17 & -- & -- & -. & 1 & -- & .. & -- & 1 & - & 1 & 4.5 & 1.2 \\
\hline 670 & -- & 4 & 16 & 3 & -- & -- & 1 & -- & 2 & -- & -- & -. & 1 & 3.7 & 0.1 \\
\hline 680 & 1 & -- & 23 & 1 & -- & -- & .. & -- & -- & 1 & -- & -- & -- & 3.3 & 0.8 \\
\hline 690 & - & 3 & 25 & -- & -- & -- & -- & -- & 1 & -. & -- & -- & 2 & 3.1 & 1.6 \\
\hline 700 & 1 & 1 & 21 & 1 & -- & -- & -- & -- & -- & -- & -- & -- & 2 & 1.6 & 0.6 \\
\hline 710 & -- & 2 & 35 & -- & 1 & -- & -- & -- & -- & -- & -- & -- & 1 & 1.0 & 2.4 \\
\hline 720 & -- & 6 & 26 & 2 & & -- & -- & -- & -. & -- & -- & - & 6 & 1.3 & 1.4 \\
\hline 730 & 3 & 2 & 23 & 1 & 1 & - & -- & 1 & -- & -. & -- & 1 & 2 & 3.1 & 0.8 \\
\hline 740 & -- & 4 & 18 & -- & 1 & 1 & - & -- & - & .. & -- & 2 & -- & 1.5 & 3.5 \\
\hline 750 & 13 & 10 & 9 & -- & 4 & 1 & 2 & 1 & 6 & 5 & -- & 3 & 1 & 2.4 & 2.3 \\
\hline 760 & 8 & 8 & 12 & -- & 5 & -- & -- & 1 & 1 & 3 & 2 & 2 & 2 & 1.1 & 0.5 \\
\hline 770 & 10 & 4 & 6 & 2 & 7 & 1 & 2 & -- & -- & -- & 1 & 1 & 2 & 0.5 & 1.8 \\
\hline 780 & 6 & 1 & 7 & 1 & 2 & 1 & -- & 1 & 2 & -- & -. & 1 & -- & 6.3 & 2.9 \\
\hline 790 & 1 & - & 2 & -- & -- & -- & -- & -. & -- & -- & -. & -- & 1 & 2.4 & 2.0 \\
\hline 800 & 4 & 1 & 24 & 1 & -- & -- & -- & -- & 1 & -- & -. & -- & 4 & 0.5 & 1.9 \\
\hline 810 & 5 & 4 & 21 & -- & 1 & -- & -- & 3 & 2 & -- & -- & 1 & 2 & 0.6 & 1.6 \\
\hline 820 & 2 & 5 & 22 & -- & -- & -- & - & -- & -- & -- & 2 & 3 & 2 & 0.0 & 0.4 \\
\hline 830 & 9 & 3 & 10 & -- & 2 & 1 & -- & -- & - & 1 & 3 & 3 & 2 & 0.0 & 0.3 \\
\hline 840 & 6 & 2 & 8 & -- & 2 & -- & - & -- & -- & -- & 2 & 2 & 2 & 0.5 & 0.3 \\
\hline 850 & 4 & -- & 19 & -- & 1 & 1 & -- & -- & -- & -. & -- & -- & 2 & 2.5 & 0.2 \\
\hline 860 & 8 & 5 & 18 & -- & 3 & 1 & 1 & -- & 1 & 1 & -- & 1 & 5 & 7.3 & 1.6 \\
\hline 870 & 1 & 1 & 6 & -- & -- & -- & -- & -- & -. & - & -- & 1 & 1 & 6.8 & 1.8 \\
\hline 880 & 2 & -- & 10 & -- & -- & -- & -- & -- & -. & -- & -- & 1 & 1 & 8.0 & 1.5 \\
\hline 890 & -- & -- & 3 & -- & -- & -- & -- & -. & -- & -- & -- & -- & - & 7.8 & 0.8 \\
\hline 900 & -- & 1 & 9 & -- & 1 & -- & -- & -- & -- & -- & -- & -- & -- & 4.4 & 2.6 \\
\hline 910 & 1 & 3 & 18 & -- & -- & -- & -- & - & -- & -- & 1 & -- & 3 & 10.0 & - \\
\hline 920 & -- & -- & -- & -- & -- & -- & -- & -- & -. & -- & -- & -- & -- & 4.9 & 2.6 \\
\hline 930 & 1 & 5 & 15 & -- & 3 & -- & -- & -- & -- & -- & -- & -- & 3 & 3.3 & 2.6 \\
\hline 940 & 3 & 2 & 18 & -- & 2 & -- & -- & -- & -- & -- & 1 & 2 & & 5.6 & 0.6 \\
\hline 950 & -- & 2 & 18 & -. & -- & -- & -- & - & -. & -- & - & 1 & 1 & 5.5 & 1.3 \\
\hline 960 & 4 & 1 & 17 & -- & 1 & - & -- & -- & -- & -- & - & 1 & 3 & 3.1 & 1.4 \\
\hline 970 & 1 & 4 & 21 & -. & 2 & -- & -- & - & -. & -- & -- & -. & 3 & 5.4 & 3.2 \\
\hline 980 & 1 & 1 & 10 & -- & - & -- & -- & - & -- & -- & - & -- & 2 & 2.0 & 1.8 \\
\hline 990 & 2 & 4 & 26 & - & -- & -- & -- & -- & -- & 1 & 1 & 2 & 2 & 2.8 & 2.1 \\
\hline
\end{tabular}


Table F-1: Measured Fracture Data for 10-foot Composite Intervals (Continued)

[N-natural, I-indeterminate, $\mathrm{C}$-coring-induced, $\mathrm{V}$-vug or void; dip classes are 10-degree intervals ending with the indicated value. Source: DTN SNF29041993002.069]

\begin{tabular}{|c|c|c|c|c|c|c|c|c|c|c|c|c|c|c|c|}
\hline \multirow{2}{*}{$\begin{array}{l}\text { Depth to } \\
\text { Base of } \\
\text { Interval } \\
\text { (feet) }\end{array}$} & \multicolumn{4}{|c|}{ Type of Fracture } & \multicolumn{9}{|c|}{ Dip of Fracture (degrees) } & \multirow{2}{*}{$\begin{array}{l}\text { Lost } \\
\text { Core } \\
\text { (feet) }\end{array}$} & \multirow{2}{*}{$\begin{array}{l}\text { Rubble } \\
\text { (feet) }\end{array}$} \\
\hline & $\mathbf{N}$ & 1 & C & v & 10 & 20 & 30 & 40 & 50 & 60 & 70 & 80 & 90 & & \\
\hline 1000 & - & - & 25 & -- & -- & -- & -- & -- & -- & -- & -- & -- & -- & 6.4 & 1.0 \\
\hline 1010 & -- & 1 & 19 & -- & 1 & -- & -- & -. & -. & -- & -- & -- & -- & 6.3 & 1.1 \\
\hline 1020 & -- & 2 & 17 & 1 & -- & -- & -- & -- & -- & -- & -- & -- & 2 & 4.3 & 2.0 \\
\hline 1030 & 2 & 1 & 16 & 4 & -- & .- & -- & -- & -- & -- & -- & -- & 3 & 1.8 & 1.0 \\
\hline 1040 & -- & 3 & 27 & -- & 1 & -- & 1 & -- & -. & -- & -- & 1 & -- & 1.1 & 1.6 \\
\hline 1050 & 5 & 4 & 15 & 2 & 5 & 1 & -- & -- & -- & 1 & 2 & -- & -- & 3.4 & 1.5 \\
\hline 1060 & 4 & -- & 19 & 1 & -- & -- & -- & 1 & -- & -- & 1 & -- & 2 & 0.4 & 2.2 \\
\hline 1070 & 2 & 7 & 28 & .- & 2 & -- & 1 & 1 & -- & -- & 1 & 1 & 3 & 6.2 & 1.5 \\
\hline 1080 & 1 & 2 & 11 & -- & -- & -- & 1 & -- & -- & -- & -- & 1 & 1 & 4.3 & 4.4 \\
\hline 1090 & 2 & 2 & 9 & -- & 2 & -- & -- & -- & -- & -- & -- & -- & 2 & 2.2 & 2.9 \\
\hline 1100 & 4 & 5 & 18 & -- & 3 & -- & -- & -- & 1 & -- & 1 & 2 & 2 & 0.9 & 1.6 \\
\hline 1110 & 1 & 6 & 15 & -- & 3 & 1 & -- & -- & -- & -- & 1 & 1 & 1 & 1.8 & 1.3 \\
\hline 1120 & -- & - & 18 & 1 & -- & -- & -- & -- & -- & -- & -- & -- & -- & 0.6 & 3.1 \\
\hline 1130 & 2 & 3 & 17 & 1 & 1 & -- & -- & -- & 3 & -- & -- & -- & 1 & 3.9 & 1.7 \\
\hline 1140 & 4 & 5 & 14 & -- & 1 & -- & -- & -- & -- & 1 & -- & -- & 7 & 0.7 & 1.5 \\
\hline 1150 & 4 & 3 & 30 & -- & 3 & I & -- & -- & -- & -- & -- & -- & 3 & 2.2 & 2.8 \\
\hline 1160 & 7 & 1 & 22 & -- & 1 & -- & -- & -- & -- & -- & 1 & -- & 6 & 1.0 & 1.2 \\
\hline 1170 & 1 & 3 & 27 & 2 & -- & -- & -- & -- & -- & 2 & 1 & -. & 1 & 2.2 & 2.5 \\
\hline 1180 & -- & 10 & 20 & -- & -- & -- & -- & 1 & 3 & -- & 1 & -- & 5 & 2.2 & 3.3 \\
\hline 1190 & 1 & 5 & 21 & -- & 1 & 1 & -- & -- & -- & -. & 1 & -- & 3 & 2.7 & 2.5 \\
\hline 1200 & 4 & 3 & 17 & -- & 1 & 1 & -- & 1 & - & -- & -- & 2 & 2 & 2.6 & 1.2 \\
\hline 1210 & 8 & 8 & 14 & -- & 1 & 7 & 1 & -- & -- & -- & -- & -- & 7 & 2.6 & 2.1 \\
\hline 1220 & 7 & 7 & 7 & -- & 1 & 2 & 4 & -- & -- & -- & 3 & 1 & 3 & 3.3 & 2.2 \\
\hline 1230 & 6 & 3 & 13 & 1 & 4 & -- & 1 & -- & -- & -- & -- & -- & 4 & 2.7 & 2.4 \\
\hline 1240 & 5 & 2 & 24 & -- & 3 & -- & -- & -- & -- & -- & -- & 2 & 2 & 2.8 & 2.3 \\
\hline 1250 & 1 & 4 & 23 & -- & 4 & - & -- & -- & -- & -- & -- & -- & 1 & 1.6 & 0.3 \\
\hline 1260 & 8 & 2 & 25 & -- & 2 & -- & -- & -- & -- & -- & -- & 2 & 6 & 4.7 & 1.8 \\
\hline 1270 & 7 & 2 & 13 & -- & 2 & -- & 1 & -- & -- & -- & -- & 2 & 4 & 0.9 & 2.3 \\
\hline 1280 & 13 & 3 & 16 & -- & 10 & 1 & & -- & -- & -- & 1 & 1 & 3 & 3.7 & 1.6 \\
\hline 1290 & 8 & 2 & 9 & 2 & 3 & -- & 2 & -- & 1 & 1 & -- & -- & 3 & 3.0 & 2.0 \\
\hline 1300 & 5 & 3 & 16 & 2 & 2 & -- & 1 & -- & -- & - & 1 & -- & 4 & 1.7 & 1.4 \\
\hline 1310 & 5 & 9 & 28 & -- & 5 & -- & -- & - & -- & -- & 3 & 4 & 2 & 4.1 & 1.8 \\
\hline 1320 & 5 & 14 & 2 & -- & 14 & 1 & 2 & -- & -- & -- & -- & 1 & 1 & 4.8 & 2.6 \\
\hline 1330 & 2 & 8 & 3 & -- & 7 & -- & -- & 1 & -- & -- & -- & 1 & 1 & 0.0 & 2.9 \\
\hline 1340 & 5 & 13 & 22 & -- & 6 & 1 & 1 & 1 & 3 & 1 & 1 & 2 & 2 & 5.2 & 2.6 \\
\hline 1350 & 1 & 3 & 10 & -- & -- & -- & 1 & $=$ & -- & -- & -- & -- & 3 & -- & -- \\
\hline
\end{tabular}


Appendix G: Laboratory Material Properties 
Table G-1: Laboratory Material Properties and Water Contents Measured on Core Samples from Drill Hole USW SD-9

[Measurements reported by L.E. Flint, U.S. Geological Survey Hydrologic Research Facility; DTN No. GS950308312231.004. J. Curtis and C. Vidano, analysts. Sample number consists of "SD9-" plus depth in feet]

\begin{tabular}{|c|c|c|c|c|c|c|c|c|c|c|c|c|}
\hline \multirow[b]{2}{*}{$\begin{array}{l}\text { Depth } \\
\text { (feet) }\end{array}$} & \multicolumn{6}{|c|}{ Relative Humidity Oven Dried } & \multicolumn{6}{|c|}{$105^{\circ} \mathrm{C}$ Oven-Dried } \\
\hline & $\begin{array}{c}\text { Dry Bulk } \\
\text { Density } \\
\left(\mathrm{g} / \mathrm{cm}^{\prime}\right)\end{array}$ & $\begin{array}{l}\text { Porosity } \\
\left(\mathrm{cm}^{1} / \mathrm{cm}^{3}\right)\end{array}$ & $\begin{array}{l}\text { Particle } \\
\text { Density } \\
\left(\mathrm{g}^{\prime} \mathrm{cm}^{\prime}\right)\end{array}$ & $\begin{array}{c}\text { Grav. } \\
\text { Water } \\
\text { Content } \\
(\mathrm{g} / \mathrm{g})\end{array}$ & $\begin{array}{c}\text { Vol. } \\
\text { Water } \\
\text { Content } \\
\left(\mathrm{cm}^{3} / \mathrm{cm}^{3}\right)\end{array}$ & $\begin{array}{c}\text { Relative } \\
\text { Satn. }\end{array}$ & $\begin{array}{l}\text { Dry Bulk } \\
\text { Density } \\
\left(\mathrm{g} / \mathrm{cm}^{3}\right)\end{array}$ & $\begin{array}{l}\text { Porosity } \\
\left(\mathrm{cm}^{3} / \mathrm{cm}^{3}\right)\end{array}$ & $\begin{array}{l}\text { Particle } \\
\text { Density } \\
\text { (g/cm })\end{array}$ & $\begin{array}{c}\text { Grav. } \\
\text { Water } \\
\text { Content } \\
(\mathrm{g} / \mathrm{g})\end{array}$ & $\begin{array}{c}\text { Vol. } \\
\text { Water } \\
\text { Content } \\
\left.\text { (cm } \text { cm }^{3} / \mathrm{cm}^{3}\right)\end{array}$ & $\begin{array}{c}\text { Relative } \\
\text { Satn. }\end{array}$ \\
\hline 56.6 & 1.59 & 0.286 & 2.22 & 0.173 & 0.275 & 0.962 & 1.42 & 0.452 & 2.59 & 0.310 & 0.441 & 0.976 \\
\hline 59.4 & 1.95 & 0.121 & 2.22 & 0.062 & 0.120 & 0.992 & 1.80 & 0.268 & 2.46 & 0.148 & 0.267 & 0.996 \\
\hline 61.6 & 1.83 & 0.167 & 2.20 & 0.089 & 0.163 & 0.974 & 1.67 & 0.328 & 2.49 & 0.194 & 0.324 & 0.987 \\
\hline 64.9 & 1.94 & 0.133 & 2.24 & 0.053 & 0.102 & 0.767 & 1.84 & 0.237 & 2.41 & 0.112 & 0.206 & 0.869 \\
\hline 67.9 & 1.92 & 0.146 & 2.25 & 0.076 & 0.146 & 0.994 & 1.84 & 0.228 & 2.38 & 0.123 & 0.227 & 0.996 \\
\hline 71.0 & 1.76 & 0.227 & 2.28 & 0.114 & 0.201 & 0.886 & 1.69 & 0.299 & 2.41 & 0.161 & 0.273 & 0.914 \\
\hline 73.8 & 1.69 & 0.256 & 2.27 & 0.149 & 0.252 & 0.985 & 1.63 & 0.311 & 2.37 & 0.188 & 0.307 & 0.988 \\
\hline 77.0 & 1.58 & 0.255 & 2.13 & 0.129 & 0.205 & 0.802 & 1.54 & 0.297 & 2.19 & 0.159 & 0.246 & 0.829 \\
\hline 80.0 & 1.45 & 0.335 & 2.19 & 0.145 & 0.211 & 0.629 & 1.41 & 0.376 & 2.26 & 0.178 & 0.252 & 0.670 \\
\hline 82.9 & 1.41 & 0.372 & 2.25 & 0.121 & 0.171 & 0.460 & 1.37 & 0.413 & 2.34 & 0.155 & 0.212 & 0.514 \\
\hline 86.4 & 1.41 & 0.362 & 2.21 & 0.127 & 0.179 & 0.495 & 1.37 & 0.398 & 2.28 & 0.156 & 0.215 & 0.540 \\
\hline 88.3 & 1.43 & 0.351 & 2.20 & 0.122 & 0.174 & 0.494 & 1.38 & 0.396 & 2.28 & 0.158 & 0.218 & 0.551 \\
\hline 94.8 & 0.97 & 0.569 & 2.24 & 0.333 & 0.322 & 0.566 & 0.92 & 0.619 & 2.40 & 0.406 & 0.372 & 0.601 \\
\hline 97.7 & 1.26 & 0.427 & 2.20 & 0.125 & 0.158 & 0.369 & 1.23 & 0.453 & 2.25 & 0.149 & 0.184 & 0.406 \\
\hline 100.4 & 1.29 & 0.413 & 2.20 & 0.109 & 0.141 & 0.341 & 1.27 & 0.433 & 2.24 & 0.127 & 0.161 & 0.372 \\
\hline 104.0 & 1.38 & 0.367 & 2.18 & 0.102 & 0.141 & 0.383 & 1.36 & 0.387 & 2.22 & 0.118 & 0.161 & 0.415 \\
\hline 107.2 & 1.40 & 0.363 & 2.19 & 0.121 & 0.169 & 0.465 & 1.37 & 0.387 & 2.24 & 0.140 & 0.192 & 0.497 \\
\hline 110.4 & 1.47 & 0.310 & 2.13 & 0.125 & 0.184 & 0.592 & 1.45 & 0.332 & 2.17 & 0.142 & 0.205 & 0.619 \\
\hline 113.2 & 1.51 & 0.292 & 2.13 & 0.124 & 0.187 & 0.638 & 1.49 & 0.311 & 2.16 & 0.138 & 0.205 & 0.660 \\
\hline 115.7 & 1.53 & 0.262 & 2.07 & 0.106 & 0.162 & 0.618 & 1.50 & 0.289 & 2.11 & 0.126 & 0.189 & 0.654 \\
\hline 118.9 & 1.53 & 0.270 & 2.09 & 0.147 & 0.224 & 0.830 & 1.51 & 0.290 & 2.12 & 0.162 & 0.244 & 0.841 \\
\hline 122.0 & 1.49 & 0.287 & 2.08 & 0.131 & 0.195 & 0.679 & 1.47 & 0.304 & 2.11 & 0.144 & 0.212 & 0.697 \\
\hline 125.3 & 1.49 & 0.304 & 2.15 & 0.100 & 0.149 & 0.489 & 1.48 & 0.323 & 2.18 & 0.114 & 0.168 & 0.519 \\
\hline 133.5 & 1.42 & 0.335 & 2.13 & 0.093 & 0.132 & 0.395 & 1.39 & 0.357 & 2.17 & 0.111 & 0.154 & 0.432 \\
\hline 137.3 & 1.43 & 0.347 & 2.19 & 0.090 & 0.128 & 0.370 & 1.40 & 0.373 & 2.24 & 0.111 & 0.155 & 0.415 \\
\hline 140.4 & 1.40 & 0.357 & 2.18 & 0.088 & 0.123 & 0.345 & 1.37 & 0.384 & 2.23 & 0.109 & 0.150 & 0.390 \\
\hline 142.7 & 1.59 & 0.310 & 2.30 & 0.088 & 0.139 & 0.448 & 1.56 & 0.337 & 2.35 & 0.106 & 0.165 & 0.491 \\
\hline 152.2 & 1.54 & 0.308 & 2.23 & 0.082 & 0.126 & 0.409 & 1.50 & 0.353 & 2.32 & 0.114 & 0.171 & 0.484 \\
\hline 155.0 & 1.31 & 0.412 & 2.23 & 0.133 & 0.174 & 0.423 & 1.23 & 0.493 & 2.42 & 0.208 & 0.255 & 0.518 \\
\hline 157.8 & 1.14 & 0.477 & 2.19 & 0.146 & 0.167 & 0.350 & 1.10 & 0.518 & 2.29 & 0.188 & 0.208 & 0.401 \\
\hline 160.7 & 1.09 & 0.490 & 2.13 & 0.132 & 0.144 & 0.294 & 1.07 & 0.508 & 2.17 & 0.152 & 0.162 & 0.320 \\
\hline
\end{tabular}


Table G-1: Laboratory Material Properties and Water Contents Measured on Core Samples from Drill Hole USW SD-9 (Continued)

[Measurements reported by L.E. Fint, U.S. Geological Survey Hydrologic Research Facility; DTN No. GS950308312231.004. J. Curtis and C. Vidano, analysts. Sample number consists of "SD9-" plus depth in feet]

\begin{tabular}{|c|c|c|c|c|c|c|c|c|c|c|c|c|}
\hline \multirow[b]{2}{*}{$\begin{array}{l}\text { Depth } \\
\text { (feet) }\end{array}$} & \multicolumn{6}{|c|}{ Relative Humidity Oven Dried } & \multicolumn{6}{|c|}{$105^{\circ} \mathrm{C}$ Oven-Dried } \\
\hline & $\begin{array}{l}\text { Dry Bulk } \\
\text { Density } \\
\text { (g/cm³) }\end{array}$ & $\begin{array}{l}\text { Porosity } \\
\left(\mathrm{cm}^{3} / \mathrm{cm}^{3}\right)\end{array}$ & $\begin{array}{l}\text { Particle } \\
\text { Density } \\
\text { (g/cm })\end{array}$ & $\begin{array}{c}\text { Grav. } \\
\text { Water } \\
\text { Content } \\
(\mathbf{g} / \mathbf{g})\end{array}$ & $\begin{array}{c}\text { Vol. } \\
\text { Water } \\
\text { Content } \\
\left(\mathrm{cm}^{3} / \mathrm{cm}^{3}\right)\end{array}$ & $\begin{array}{c}\text { Relative } \\
\text { Satn. }\end{array}$ & $\begin{array}{l}\text { Dry Bulk } \\
\text { Density } \\
\text { (g/cm³) }\end{array}$ & $\begin{array}{l}\text { Porosity } \\
\left(\mathrm{cm}^{3} / \mathrm{cm}^{3}\right)\end{array}$ & $\begin{array}{l}\text { Particle } \\
\text { Density } \\
\text { (g/cm³) }\end{array}$ & $\begin{array}{c}\text { Grav. } \\
\text { Water } \\
\text { Content } \\
(\mathbf{g} / \mathbf{g})\end{array}$ & $\begin{array}{c}\text { Vol. } \\
\text { Water } \\
\text { Content } \\
\left(\mathrm{cm}^{3} / \mathrm{cm}^{3}\right)\end{array}$ & $\begin{array}{c}\text { Relative } \\
\text { Satn. }\end{array}$ \\
\hline 163.8 & 1.09 & 0.456 & 2.01 & 0.117 & 0.128 & 0.281 & 1.08 & 0.470 & 2.04 & 0.132 & 0.142 & 0.302 \\
\hline 169.5 & 1.19 & 0.427 & 2.07 & 0.117 & 0.139 & 0.325 & 1.17 & 0.440 & 2.10 & 0.129 & 0.152 & 0.345 \\
\hline 172.8 & 1.23 & 0.411 & 2.09 & 0.106 & 0.131 & 0.318 & 1.22 & 0.426 & 2.12 & 0.119 & 0.145 & 0.342 \\
\hline 185.5 & 1.07 & 0.463 & 1.99 & 0.102 & 0.108 & 0.234 & 1.06 & 0.471 & 2.00 & 0.110 & 0.116 & 0.247 \\
\hline 187.8 & 1.11 & 0.485 & 2.16 & 0.095 & 0.106 & 0.218 & 1.10 & 0.501 & 2.20 & 0.112 & 0.122 & 0.244 \\
\hline 209.2 & 1.11 & 0.478 & 2.12 & 0.124 & 0.138 & 0.289 & 1.10 & 0.490 & 2.15 & 0.137 & 0.151 & 0.307 \\
\hline 212.1 & 1.13 & 0.452 & 2.06 & 0.115 & 0.130 & 0.288 & 1.11 & 0.468 & 2.09 & 0.132 & 0.147 & 0.314 \\
\hline 214.6 & 1.16 & 0.445 & 2.10 & 0.123 & 0.143 & 0.321 & 1.15 & 0.460 & 2.13 & 0.137 & 0.158 & 0.343 \\
\hline 217.8 & 1.14 & 0.442 & 2.05 & 0.124 & 0.142 & 0.321 & 1.13 & 0.458 & 2.08 & 0.139 & 0.157 & 0.343 \\
\hline 220.6 & 1.17 & 0.410 & 1.99 & 0.127 & 0.149 & 0.364 & 1.15 & 0.429 & 2.02 & 0.145 & 0.168 & 0.392 \\
\hline 224.0 & 1.10 & 0.452 & 2.01 & 0.125 & 0.138 & 0.305 & 1.08 & 0.478 & 2.07 & 0.153 & 0.165 & 0.344 \\
\hline 230.0 & 1.40 & 0.347 & 2.15 & 0.067 & 0.093 & 0.269 & 1.36 & 0.389 & 2.23 & 0.099 & 0.135 & 0.347 \\
\hline 232.8 & 1.13 & 0.478 & 2.16 & 0.108 & 0.121 & 0.254 & 1.09 & 0.512 & 2.24 & 0.143 & 0.156 & 0.305 \\
\hline 238.6 & 1.02 & 0.508 & 2.08 & 0.123 & 0.125 & 0.247 & 1.00 & 0.527 & 2.12 & 0.144 & 0.144 & 0.274 \\
\hline 241.8 & 1.10 & 0.460 & 2.04 & 0.087 & 0.096 & 0.208 & 1.06 & 0.503 & 2.13 & 0.131 & 0.139 & 0.276 \\
\hline 245.8 & 0.98 & 0.501 & 1.97 & 0.120 & 0.118 & 0.235 & 0.97 & 0.509 & 1.99 & 0.130 & 0.126 & 0.248 \\
\hline 247.8 & 1.06 & 0.516 & 2.20 & 0.109 & 0.116 & 0.225 & 1.04 & 0.539 & 2.26 & 0.134 & 0.139 & 0.258 \\
\hline 251.1 & 1.06 & 0.509 & 2.17 & 0.109 & 0.116 & 0.229 & 1.05 & 0.527 & 2.21 & 0.129 & 0.135 & 0.256 \\
\hline 256.8 & 1.18 & 0.480 & 2.28 & 0.137 & 0.162 & 0.337 & 1.14 & 0.520 & 2.38 & 0.177 & 0.202 & 0.388 \\
\hline 260.3 & 1.16 & 0.479 & 2.22 & 0.131 & 0.151 & 0.316 & 1.10 & 0.540 & 2.38 & 0.194 & 0.213 & 0.394 \\
\hline 262.7 & 1.13 & 0.470 & 2.13 & 0.159 & 0.180 & 0.383 & 1.11 & 0.485 & 2.16 & 0.175 & 0.195 & 0.402 \\
\hline 265.9 & 1.52 & 0.284 & 2.13 & 0.122 & 0.186 & 0.657 & 1.51 & 0.298 & 2.15 & 0.133 & 0.201 & 0.674 \\
\hline 270.8 & 2.37 & 0.038 & 2.46 & 0.011 & 0.025 & 0.675 & 2.36 & 0.040 & 2.46 & 0.012 & 0.028 & 0.698 \\
\hline 278.0 & 2.50 & 0.011 & 2.52 & 0.003 & 0.007 & 0.611 & 2.49 & 0.022 & 2.54 & 0.007 & 0.017 & 0.802 \\
\hline 280.6 & 2.46 & 0.015 & 2.50 & 0.003 & 0.007 & 0.451 & 2.44 & 0.031 & 2.52 & 0.009 & 0.022 & 0.722 \\
\hline 283.6 & 2.40 & 0.041 & 2.50 & 0.012 & 0.029 & 0.712 & 2.38 & 0.061 & 2.53 & 0.021 & 0.049 & 0.806 \\
\hline 286.9 & 2.40 & 0.033 & 2.48 & 0.008 & 0.019 & 0.565 & 2.37 & 0.058 & 2.52 & 0.018 & 0.043 & 0.750 \\
\hline 290.9 & 2.40 & 0.034 & 2.49 & 0.005 & 0.011 & 0.321 & 2.38 & 0.056 & 2.52 & 0.014 & 0.033 & 0.587 \\
\hline 292.9 & 2.39 & 0.045 & 2.50 & 0.014 & 0.034 & 0.751 & 2.37 & 0.068 & 2.54 & 0.024 & 0.057 & 0.836 \\
\hline 298.9 & 2.34 & 0.054 & 2.47 & 0.016 & 0.037 & 0.681 & 2.30 & 0.094 & 2.54 & 0.034 & 0.077 & 0.819 \\
\hline 308.0 & 2.14 & 0.133 & 2.47 & 0.042 & 0.090 & 0.675 & 2.11 & 0.166 & 2.53 & 0.058 & 0.122 & 0.739 \\
\hline
\end{tabular}


Table G-1: Laboratory Material Properties and Water Contents Measured on Core Samples from Drill Hole USW SD-9 (Continued)

[Measurements reported by L.E. Flint, U.S. Geological Survey Hydrologic Research Facility; DTN No. GS950308312231.004. J. Curtis and C. Vidano, analysts. Sample number consists of "SD9-" plus depth in feet]

\begin{tabular}{|c|c|c|c|c|c|c|c|c|c|c|c|c|}
\hline \multirow[b]{2}{*}{$\begin{array}{l}\text { Depth } \\
\text { (feet) }\end{array}$} & \multicolumn{6}{|c|}{ Relative Humidity Oven Dried } & \multicolumn{6}{|c|}{$105^{\circ} \mathrm{C}$ Oven-Dried } \\
\hline & $\begin{array}{l}\text { Dry Bulk } \\
\text { Density } \\
\text { (g/cm') }\end{array}$ & $\begin{array}{l}\text { Porosity } \\
\left(\mathrm{cm}^{3 /} / \mathrm{cm}^{3}\right)\end{array}$ & $\begin{array}{l}\text { Particle } \\
\text { Density } \\
\left(\mathrm{g} / \mathrm{cm}^{3}\right)\end{array}$ & $\begin{array}{c}\text { Grav. } \\
\text { Water } \\
\text { Content } \\
(g / g)\end{array}$ & $\begin{array}{c}\text { Vol. } \\
\text { Water } \\
\text { Content } \\
\left(\mathrm{cm}^{3} / \mathrm{cm}^{3}\right)\end{array}$ & $\begin{array}{c}\text { Relative } \\
\text { Satn. }\end{array}$ & $\begin{array}{l}\text { Dry Bulk } \\
\text { Density } \\
\text { (g/cm³) }\end{array}$ & $\begin{array}{l}\text { Porosity } \\
\left(\mathrm{cm}^{3} / \mathrm{cm}^{3}\right)\end{array}$ & $\begin{array}{l}\text { Particle } \\
\text { Density } \\
\left.\text { ( } \mathrm{g} / \mathrm{cm}^{3}\right)\end{array}$ & $\begin{array}{c}\text { Grav. } \\
\text { Water } \\
\text { Content } \\
(\mathbf{g} / g)\end{array}$ & $\begin{array}{c}\text { Vol. } \\
\text { Water } \\
\text { Content } \\
\left(\mathbf{c m}^{3} / \mathbf{c m}^{3}\right)\end{array}$ & $\begin{array}{c}\text { Relative } \\
\text { Satn. }\end{array}$ \\
\hline 313.5 & 2.32 & 0.076 & 2.51 & 0.020 & 0.046 & 0.606 & 2.30 & 0.100 & 2.55 & 0.031 & 0.070 & 0.702 \\
\hline 317.1 & 2.37 & 0.064 & 2.54 & 0.017 & 0.041 & 0.644 & 2.35 & 0.085 & 2.57 & 0.026 & 0.062 & 0.731 \\
\hline 323.0 & 2.07 & 0.193 & 2.57 & 0.043 & 0.088 & 0.456 & 2.06 & 0.201 & 2.58 & 0.046 & 0.095 & 0.476 \\
\hline 326.0 & 2.23 & 0.125 & 2.55 & 0.031 & 0.068 & 0.546 & 2.21 & 0.143 & 2.58 & 0.039 & 0.086 & 0.602 \\
\hline 329.5 & 2.25 & 0.112 & 2.53 & 0.029 & 0.065 & 0.583 & 2.24 & 0.126 & 2.56 & 0.036 & 0.080 & 0.631 \\
\hline 330.9 & 2.09 & 0.188 & 2.57 & 0.040 & 0.084 & 0.445 & 2.08 & 0.197 & 2.59 & 0.044 & 0.092 & 0.468 \\
\hline 335.3 & 2.21 & 0.129 & 2.54 & 0.028 & 0.061 & 0.476 & 2.20 & 0.142 & 2.56 & 0.034 & 0.075 & 0.525 \\
\hline 338.0 & 2.18 & 0.148 & 2.56 & 0.029 & 0.063 & 0.423 & 2.17 & 0.160 & 2.58 & 0.034 & 0.074 & 0.464 \\
\hline 341.2 & 2.08 & 0.186 & 2.56 & 0.036 & 0.075 & 0.405 & 2.07 & 0.195 & 2.57 & 0.040 & 0.084 & 0.430 \\
\hline 344.2 & 2.21 & 0.141 & 2.57 & 0.029 & 0.065 & 0.458 & 2.20 & 0.152 & 2.59 & 0.034 & 0.076 & 0.497 \\
\hline 350.1 & 2.12 & 0.178 & 2.58 & 0.037 & 0.078 & 0.435 & 2.11 & 0.186 & 2.59 & 0.040 & 0.085 & 0.457 \\
\hline 352.8 & 2.19 & 0.155 & 2.60 & 0.035 & 0.076 & 0.491 & 2.19 & 0.165 & 2.62 & 0.039 & 0.086 & 0.521 \\
\hline 359.5 & 2.18 & 0.143 & 2.55 & 0.041 & 0.090 & 0.627 & 2.18 & 0.150 & 2.56 & 0.044 & 0.096 & 0.642 \\
\hline 365.1 & 2.15 & 0.161 & 2.56 & 0.035 & 0.075 & 0.464 & 2.14 & 0.168 & 2.57 & 0.038 & 0.082 & 0.487 \\
\hline 376.5 & 2.19 & 0.148 & 2.57 & 0.036 & 0.079 & 0.534 & 2.18 & 0.155 & 2.58 & 0.039 & 0.086 & 0.554 \\
\hline 380.4 & 2.15 & 0.158 & 2.56 & 0.036 & 0.078 & 0.493 & 2.14 & 0.169 & 2.58 & 0.041 & 0.089 & 0.526 \\
\hline 382.4 & 2.20 & 0.135 & 2.55 & 0.036 & 0.080 & 0.591 & 2.20 & 0.138 & 2.55 & 0.038 & 0.083 & 0.602 \\
\hline 385.3 & 2.20 & 0.140 & 2.56 & 0.035 & 0.077 & 0.551 & 2.19 & 0.148 & 2.57 & 0.039 & 0.085 & 0.576 \\
\hline 388.8 & 2.22 & 0.132 & 2.55 & 0.043 & 0.096 & 0.728 & 2.21 & 0.138 & 2.57 & 0.046 & 0.102 & 0.739 \\
\hline $395.1^{\prime}$ & 2.21 & 0.132 & 2.54 & 0.037 & 0.082 & 0.622 & 2.20 & 0.143 & 2.56 & 0.042 & 0.092 & 0.649 \\
\hline 398.6 & 2.23 & 0.117 & 2.53 & 0.035 & 0.079 & 0.670 & 2.22 & 0.130 & 2.55 & 0.041 & 0.091 & 0.701 \\
\hline 404.5 & 2.22 & 0.124 & 2.54 & 0.037 & 0.083 & 0.665 & 2.21 & 0.137 & 2.56 & 0.043 & 0.095 & 0.696 \\
\hline 407.5 & 2.23 & 0.118 & 2.52 & 0.038 & 0.084 & 0.714 & 2.21 & 0.134 & 2.55 & 0.046 & 0.101 & 0.749 \\
\hline 410.0 & 2.24 & 0.110 & 2.52 & 0.036 & 0.080 & 0.730 & 2.23 & 0.122 & 2.54 & 0.041 & 0.092 & 0.757 \\
\hline 413.0 & 2.27 & 0.098 & 2.52 & 0.031 & 0.071 & 0.721 & 2.26 & 0.113 & 2.54 & 0.038 & 0.085 & 0.756 \\
\hline 415.6 & 2.27 & 0.096 & 2.51 & 0.031 & 0.071 & 0.747 & 2.25 & 0.111 & 2.54 & 0.039 & 0.087 & 0.782 \\
\hline 419.1 & 2.25 & 0.108 & 2.52 & 0.034 & 0.077 & 0.709 & 2.23 & 0.123 & 2.55 & 0.041 & 0.092 & 0.744 \\
\hline 421.6 & 2.26 & 0.096 & 2.49 & 0.032 & 0.073 & 0.759 & 2.24 & 0.115 & 2.53 & 0.041 & 0.092 & 0.800 \\
\hline 425.1 & 2.28 & 0.087 & 2.49 & 0.031 & 0.071 & 0.814 & 2.26 & 0.106 & 2.53 & 0.040 & 0.090 & 0.848 \\
\hline 430.3 & 2.29 & 0.083 & 2.50 & 0.030 & 0.068 & 0.820 & 2.27 & 0.101 & 2.53 & 0.038 & 0.086 & 0.852 \\
\hline 433.8 & 2.24 & 0.102 & 2.49 & 0.034 & 0.077 & 0.750 & 2.22 & 0.120 & 2.52 & 0.043 & 0.094 & 0.787 \\
\hline
\end{tabular}


Table G-1: Laboratory Material Properties and Water Contents Measured on Core Samples from Drill Hole USW SD-9 (Continued)

[Measurements reported by L.E. Fint, U.S. Geological Survey Hydrologic Research Facility; DTN No. GS950308312231.004. J. Curtis and C. Vidano, analysts. Sample number consists of "SD9-" plus depth in feet]

\begin{tabular}{|c|c|c|c|c|c|c|c|c|c|c|c|c|}
\hline \multirow[b]{2}{*}{$\begin{array}{l}\text { Depth } \\
\text { (feet) }\end{array}$} & \multicolumn{6}{|c|}{ Relative Humidity Oven Dried } & \multicolumn{6}{|c|}{$105^{\circ} \mathrm{C}$ Oven-Dried } \\
\hline & $\begin{array}{c}\text { Dry Bulk } \\
\text { Density } \\
\text { (g/cm })\end{array}$ & $\begin{array}{l}\text { Porosity } \\
\left(\mathrm{cm}^{3} / \mathrm{cm}^{3}\right)\end{array}$ & $\begin{array}{l}\text { Particle } \\
\text { Density } \\
\text { (g/cm })\end{array}$ & $\begin{array}{c}\text { Grav. } \\
\text { Water } \\
\text { Content } \\
(\mathbf{g} / \mathbf{g})\end{array}$ & $\begin{array}{c}\text { Vol. } \\
\text { Water } \\
\text { Content } \\
\left(\mathrm{cm}^{3} / \mathrm{cm}^{3}\right)\end{array}$ & $\begin{array}{c}\text { Relative } \\
\text { Satn. }\end{array}$ & $\begin{array}{l}\text { Dry Bulk } \\
\text { Density } \\
\text { (g/cm³) }\end{array}$ & $\begin{array}{l}\text { Porosity } \\
\left(\mathrm{cm}^{3} / \mathrm{cm}^{3}\right)\end{array}$ & $\begin{array}{l}\text { Particle } \\
\text { Density } \\
\left(\mathrm{g} / \mathrm{cm}^{3}\right)\end{array}$ & $\begin{array}{c}\text { Grav. } \\
\text { Water } \\
\text { Content } \\
(\mathbf{g} / \mathbf{g})\end{array}$ & $\begin{array}{c}\text { Vol. } \\
\text { Water } \\
\text { Content } \\
\left(\mathrm{cm}^{3} / \mathrm{cm}^{3}\right)\end{array}$ & $\begin{array}{c}\text { Relative } \\
\text { Satn. }\end{array}$ \\
\hline 436.8 & 2.25 & 0.097 & 2.49 & 0.032 & 0.071 & 0.728 & 2.23 & 0.115 & 2.52 & 0.040 & 0.089 & 0.770 \\
\hline 439.9 & 2.23 & 0.106 & 2.50 & 0.033 & 0.073 & 0.687 & 2.21 & 0.125 & 2.53 & 0.042 & 0.092 & 0.734 \\
\hline 445.8 & 2.29 & 0.083 & 2.50 & 0.026 & 0.060 & 0.725 & 2.27 & 0.103 & 2.53 & 0.035 & 0.080 & 0.779 \\
\hline 452.1 & 2.24 & 0.099 & 2.48 & 0.032 & 0.072 & 0.727 & 2.21 & 0.125 & 2.53 & 0.045 & 0.098 & 0.785 \\
\hline 454.7 & 2.20 & 0.104 & 2.46 & 0.034 & 0.074 & 0.708 & 2.18 & 0.130 & 2.50 & 0.046 & 0.100 & 0.765 \\
\hline 457.8 & 2.17 & 0.118 & 2.46 & 0.042 & 0.092 & 0.776 & 2.14 & 0.145 & 2.50 & 0.055 & 0.118 & 0.817 \\
\hline 466.6 & 2.13 & 0.139 & 2.47 & 0.051 & 0.109 & 0.785 & 2.10 & 0.168 & 2.53 & 0.066 & 0.138 & 0.823 \\
\hline 475.9 & 2.13 & 0.138 & 2.47 & 0.053 & 0.114 & 0.826 & 2.11 & 0.162 & 2.51 & 0.065 & 0.138 & 0.852 \\
\hline 478.9 & 2.23 & 0.097 & 2.47 & 0.040 & 0.088 & 0.911 & 2.21 & 0.120 & 2.51 & 0.050 & 0.111 & 0.928 \\
\hline 484.9 & 2.12 & 0.139 & 2.47 & 0.048 & 0.101 & 0.728 & 2.10 & 0.163 & .2 .51 & 0.060 & 0.125 & 0.768 \\
\hline 490.3 & 2.17 & 0.123 & 2.48 & 0.045 & 0.098 & 0.797 & 2.15 & 0.144 & 2.51 & 0.055 & 0.119 & 0.826 \\
\hline 500.5 & 2.14 & 0.138 & 2.48 & 0.048 & 0.102 & 0.740 & 2.12 & 0.157 & 2.52 & 0.057 & 0.121 & 0.772 \\
\hline 504.3 & 2.12 & 0.144 & 2.47 & 0.054 & 0.114 & 0.791 & 2.10 & 0.166 & 2.51 & 0.065 & 0.136 & 0.819 \\
\hline 511.9 & 2.02 & 0.183 & 2.48 & 0.053 & 0.107 & 0.585 & 2.00 & 0.202 & 2.51 & 0.063 & 0.126 & 0.624 \\
\hline 514.8 & 2.08 & 0.164 & 2.48 & 0.046 & 0.096 & 0.586 & 2.06 & 0.181 & 2.51 & 0.055 & 0.113 & 0.625 \\
\hline 518.0 & 2.10 & 0.153 & 2.48 & 0.045 & 0.094 & 0.613 & 2.08 & 0.171 & 2.51 & 0.054 & 0.112 & 0.655 \\
\hline 523.8 & 2.08 & 0.162 & 2.49 & 0.051 & 0.106 & 0.657 & 2.07 & 0.179 & 2.52 & 0.060 & 0.123 & 0.689 \\
\hline 530.7 & 2.03 & 0.172 & 2.45 & 0.056 & 0.114 & 0.662 & 2.01 & 0.192 & 2.49 & 0.067 & 0.134 & 0.697 \\
\hline 538.9 & 2.10 & 0.146 & 2.46 & 0.051 & 0.106 & 0.727 & 2.08 & 0.166 & 2.50 & 0.061 & 0.126 & 0.759 \\
\hline 553.0 & 2.11 & 0.143 & 2.47 & 0.049 & 0.104 & 0.728 & 2.09 & 0.164 & 2.50 & 0.060 & 0.125 & 0.763 \\
\hline 557.6 & 2.19 & 0.119 & 2.49 & 0.043 & 0.095 & 0.794 & 2.17 & 0.137 & 2.52 & 0.052 & 0.113 & 0.821 \\
\hline 560.8 & 2.07 & 0.156 & 2.46 & 0.057 & 0.118 & 0.755 & 2.04 & 0.188 & 2.51 & 0.073 & 0.150 & 0.797 \\
\hline 568.8 & 2.07 & 0.164 & 2.48 & 0.053 & 0.110 & 0.669 & 2.05 & 0.188 & 2.52 & 0.065 & 0.134 & 0.712 \\
\hline 575.1 & 2.08 & 0.164 & 2.48 & 0.055 & 0.115 & 0.703 & 2.05 & 0.186 & 2.52 & 0.067 & 0.137 & 0.738 \\
\hline 577.36 & 2.10 & 0.154 & 2.48 & 0.053 & 0.110 & 0.716 & 2.08 & 0.177 & 2.52 & 0.064 & 0.133 & 0.753 \\
\hline 580.9 & 2.08 & 0.163 & 2.49 & 0.055 & 0.114 & 0.697 & 2.06 & 0.184 & 2.53 & 0.065 & 0.134 & 0.731 \\
\hline 586.8 & 2.07 & 0.167 & 2.48 & 0.052 & 0.107 & 0.639 & 2.04 & 0.188 & 2.52 & 0.062 & 0.128 & 0.680 \\
\hline 589.5 & 2.02 & 0.156 & 2.39 & 0.058 & 0.116 & 0.747 & 2.00 & 0.176 & 2.43 & 0.069 & 0.137 & 0.776 \\
\hline 593 & 2.13 & 0.147 & 2.49 & 0.050 & 0.107 & 0.729 & 2.10 & 0.167 & 2.53 & 0.061 & 0.128 & 0.763 \\
\hline 596.4 & 2.10 & 0.153 & 2.48 & 0.055 & 0.116 & 0.757 & 2.08 & 0.174 & 2.52 & 0.066 & 0.137 & 0.787 \\
\hline 599.0 & 2.07 & 0.168 & 2.49 & 0.057 & 0.118 & 0.699 & 2.05 & 0.188 & 2.53 & 0.067 & 0.137 & 0.731 \\
\hline
\end{tabular}


Table G-1: Laboratory Material Properties and Water Contents Measured on Core Samples from Drill Hole USW SD-9 (Continued) [Measurements reported by L.E. Fint, U.S. Geological Survey Hydrologic Research Facility; DTN No. GS950308312231.004. J. Curtis and C. Vidano, analysts. Sample number consists of "SD9-" plus depth in feet]

\begin{tabular}{|c|c|c|c|c|c|c|c|c|c|c|c|c|}
\hline \multirow[b]{2}{*}{$\begin{array}{l}\text { Depth } \\
\text { (feet) }\end{array}$} & \multicolumn{6}{|c|}{ Relative Humidity Oven Dried } & \multicolumn{6}{|c|}{$105^{\circ} \mathrm{C}$ Oven-Drled } \\
\hline & $\begin{array}{l}\text { Dry Bulk } \\
\text { Density } \\
\text { (g/cm })\end{array}$ & $\begin{array}{l}\text { Porosity } \\
\left(\mathrm{cm}^{3} / \mathrm{cm}^{3}\right)\end{array}$ & $\begin{array}{c}\text { Particle } \\
\text { Density } \\
\left(\mathrm{g} / \mathrm{cm}^{3}\right)\end{array}$ & $\begin{array}{l}\text { Grav. } \\
\text { Water } \\
\text { Content } \\
\text { (g/g) }\end{array}$ & $\begin{array}{c}\text { Vol. } \\
\text { Water } \\
\text { Content } \\
\left(\mathrm{cm}^{3} / \mathrm{cm}^{3}\right)\end{array}$ & $\begin{array}{c}\text { Relative } \\
\text { Satn. }\end{array}$ & $\begin{array}{l}\text { Dry Bulk } \\
\text { Density } \\
\left(\mathrm{g} / \mathrm{cm}^{3}\right)\end{array}$ & $\begin{array}{l}\text { Porosity } \\
\left(\mathrm{cm}^{3} / \mathrm{cm}^{3}\right)\end{array}$ & $\begin{array}{l}\text { Particle } \\
\text { Density } \\
\left(\mathrm{g} / \mathrm{cm}^{3}\right)\end{array}$ & $\begin{array}{l}\text { Grav. } \\
\text { Water } \\
\text { Content } \\
\text { (g/g) }\end{array}$ & $\begin{array}{c}\text { Vol. } \\
\text { Water } \\
\text { Content } \\
\left(\mathrm{cm}^{3} / \mathrm{cm}^{3}\right)\end{array}$ & $\begin{array}{c}\text { Relative } \\
\text { Satn. }\end{array}$ \\
\hline 602.8 & 2.06 & 0.178 & 2.50 & 0.054 & 0.110 & 0.620 & 2.04 & 0.199 & 2.54 & 0.064 & 0.131 & 0.660 \\
\hline 605.1 & 2.07 & 0.167 & 2.49 & 0.057 & 0.119 & 0.713 & 2.05 & 0.189 & 2.53 & 0.069 & 0.141 & 0.747 \\
\hline 608.1 & 2.05 & 0.174 & 2.48 & 0.064 & 0.131 & 0.752 & 2.02 & 0.196 & 2.52 & 0.076 & 0.153 & 0.780 \\
\hline 611.9 & 2.07 & 0.170 & 2.49 & 0.051 & 0.106 & 0.623 & 2.05 & 0.191 & 2.53 & 0.062 & 0.127 & 0.664 \\
\hline 614.2 & 2.05 & 0.182 & 2.51 & 0.059 & 0.121 & 0.661 & 2.03 & 0.201 & 2.54 & 0.068 & 0.139 & 0.692 \\
\hline 617.9 & 2.11 & 0.153 & 2.49 & 0.055 & 0.116 & 0.758 & 2.09 & 0.174 & 2.53 & 0.066 & 0.137 & 0.788 \\
\hline 627.4 & 2.13 & 0.142 & 2.48 & 0.054 & 0.115 & 0.812 & 2.11 & 0.163 & 2.52 & 0.065 & 0.137 & 0.837 \\
\hline 628.7 & 2.15 & 0.140 & 2.50 & 0.052 & 0.111 & 0.794 & 2.13 & 0.162 & 2.54 & 0.062 & 0.133 & 0.822 \\
\hline 632.0 & 2.10 & 0.150 & 2.48 & 0.061 & 0.129 & 0.858 & 2.08 & 0.172 & 2.51 & 0.072 & 0.150 & 0.875 \\
\hline 647.4 & 2.14 & 0.130 & 2.46 & 0.047 & 0.100 & 0.774 & 2.12 & 0.155 & 2.51 & 0.060 & 0.126 & 0.811 \\
\hline 650.1 & 2.22 & 0.105 & 2.48 & 0.043 & 0.095 & 0.901 & 2.20 & 0.125 & 2.52 & 0.052 & 0.115 & 0.917 \\
\hline 658.6 & 2.22 & 0.106 & 2.48 & 0.043 & 0.095 & 0.902 & 2.20 & 0.127 & 2.52 & 0.053 & 0.117 & 0.919 \\
\hline 664.9 & 2.20 & 0.117 & 2.49 & 0.046 & 0.100 & 0.861 & 2.18 & 0.137 & 2.53 & 0.055 & 0.121 & 0.882 \\
\hline 671.9 & 2.15 & 0.140 & 2.50 & 0.052 & 0.112 & 0.805 & 2.13 & 0.159 & 2.54 & 0.062 & 0.132 & 0.829 \\
\hline 680.7 & 2.09 & 0.166 & 2.51 & 0.055 & 0.114 & 0.686 & 2.08 & 0.184 & 2.54 & 0.063 & 0.132 & 0.716 \\
\hline 682.7 & 2.15 & 0.142 & 2.50 & 0.047 & 0.101 & 0.711 & 2.13 & 0.161 & 2.53 & 0.056 & 0.120 & 0.746 \\
\hline 690.8 & 2.07 & 0.168 & 2.49 & 0.052 & 0.108 & 0.645 & 2.05 & 0.187 & 2.52 & 0.062 & 0.127 & 0.681 \\
\hline 693.8 & 2.17 & 0.116 & 2.45 & 0.051 & 0.110 & 0.946 & 2.14 & 0.137 & 2.48 & 0.061 & 0.131 & 0.955 \\
\hline 698.0 & 2.18 & 0.119 & 2.48 & 0.047 & 0.103 & 0.860 & 2.16 & 0.142 & 2.52 & 0.058 & 0.126 & 0.882 \\
\hline 700.2 & 2.15 & 0.138 & 2.49 & 0.053 & 0.114 & 0.823 & 2.13 & 0.157 & 2.53 & 0.062 & 0.133 & 0.845 \\
\hline 707.3 & 2.13 & 0.146 & 2.49 & 0.057 & 0.122 & 0.832 & 2.10 & 0.167 & 2.53 & 0.068 & 0.142 & 0.853 \\
\hline 709.7 & 2.15 & 0.137 & 2.50 & 0.054 & 0.117 & 0.851 & 2.13 & 0.158 & 2.53 & 0.065 & 0.138 & 0.870 \\
\hline 712.8 & 2.04 & 0.192 & 2.53 & 0.066 & 0.136 & 0.707 & 2.03 & 0.208 & 2.56 & 0.075 & 0.152 & 0.730 \\
\hline 715 & 2.26 & 0.084 & 2.47 & 0.036 & 0.081 & 0.965 & 2.24 & 0.108 & 2.51 & 0.047 & 0.105 & 0.972 \\
\hline 717.6 & 2.23 & 0.096 & 2.46 & 0.038 & 0.086 & 0.892 & 2.20 & 0.123 & 2.51 & 0.051 & 0.113 & 0.916 \\
\hline 721.8 & 2.11 & 0.147 & 2.48 & 0.060 & $0: 128$ & 0.870 & 2.09 & 0.170 & 2.52 & 0.072 & 0.151 & 0.888 \\
\hline 725.0 & 2.16 & 0.129 & 2.48 & 0.055 & 0.119 & 0.918 & 2.14 & 0.153 & 2.52 & 0.067 & 0.142 & 0.930 \\
\hline 727.1 & 2.16 & 0.130 & 2.48 & 0.056 & 0.121 & 0.932 & 2.14 & 0.153 & 2.52 & 0.068 & 0.144 & 0.943 \\
\hline 730.5 & 2.25 & 0.087 & 2.47 & 0.037 & 0.082 & 0.945 & 2.22 & 0.115 & 2.51 & 0.049 & 0.110 & 0.958 \\
\hline 733.9 & 2.23 & 0.100 & 2.48 & 0.039 & 0.087 & 0.874 & 2.20 & 0.127 & 2.52 & 0.052 & 0.115 & 0.901 \\
\hline 736.6 & 2.20 & 0.115 & 2.48 & 0.047 & 0.103 & 0.896 & 2.18 & 0.135 & 2.52 & 0.057 & 0.123 & 0.911 \\
\hline
\end{tabular}


Table G-1: Laboratory Material Properties and Water Contents Measured on Core Samples from Drill Hole USW SD-9 (Continued)

[Measurements reported by L.E. Flint, U.S. Geological Survey Hydrologic Research Facility; DTN No. GS950308312231.004. J. Curtis and C. Vidano, analysts. Sample number consists of "SD9-" plus depth in feet]

\begin{tabular}{|c|c|c|c|c|c|c|c|c|c|c|c|c|}
\hline \multirow[b]{2}{*}{$\begin{array}{l}\text { Depth } \\
\text { (feet) }\end{array}$} & \multicolumn{6}{|c|}{ Relative Humidity Oven Dried } & \multicolumn{6}{|c|}{$105^{\circ} \mathrm{C}$ Oven-Dried } \\
\hline & $\begin{array}{c}\text { Dry Bulk } \\
\text { Density } \\
\left(\mathrm{g} / \mathrm{cm}^{3}\right)\end{array}$ & $\begin{array}{l}\text { Porosity } \\
\left(\mathrm{cm}^{3} / \mathrm{cm}^{3}\right)\end{array}$ & $\begin{array}{c}\text { Particle } \\
\text { Density } \\
\left(\mathrm{g} / \mathrm{cm}^{3}\right)\end{array}$ & $\begin{array}{c}\text { Grav. } \\
\text { Water } \\
\text { Content } \\
\text { (g/g) }\end{array}$ & $\begin{array}{c}\text { Vol. } \\
\text { Water } \\
\text { Content } \\
\left(\mathrm{cm}^{3} / \mathrm{cm}^{3}\right)\end{array}$ & $\begin{array}{c}\text { Relative } \\
\text { Satn. }\end{array}$ & $\begin{array}{l}\text { Dry Bulk } \\
\text { Density } \\
\text { (g/cm³) }\end{array}$ & $\begin{array}{l}\text { Porosity } \\
\left(\mathrm{cm}^{3} / \mathrm{cm}^{3}\right)\end{array}$ & $\begin{array}{l}\text { Particle } \\
\text { Density } \\
\text { (g/cm })\end{array}$ & $\begin{array}{c}\text { Grav. } \\
\text { Water } \\
\text { Content } \\
\text { (g/g) }\end{array}$ & $\begin{array}{c}\text { Vol. } \\
\text { Water } \\
\text { Content } \\
\left(\mathrm{cm}^{3} / \mathrm{cm}^{3}\right)\end{array}$ & $\begin{array}{c}\text { Relative } \\
\text { Satn. }\end{array}$ \\
\hline 742.6 & 2.28 & 0.081 & 2.48 & 0.032 & 0.073 & 0.904 & 2.25 & 0.106 & 2.52 & 0.044 & 0.098 & 0.926 \\
\hline 746.7 & 2.30 & 0.075 & 2.49 & 0.029 & 0.066 & 0.886 & 2.28 & 0.098 & 2.52 & 0.039 & 0.089 & 0.913 \\
\hline 750.1 & 2.27 & 0.085 & 2.48 & 0.034 & 0.077 & 0.911 & 2.24 & 0.113 & 2.52 & 0.047 & 0.105 & 0.933 \\
\hline 755.6 & 2.27 & 0.083 & 2.47 & 0.025 & 0.056 & 0.675 & 2.23 & 0.116 & 2.53 & 0.040 & 0.089 & 0.766 \\
\hline 759.2 & 2.28 & 0.081 & 2.48 & 0.034 & 0.078 & 0.966 & 2.25 & 0.108 & 2.52 & 0.047 & 0.105 & 0.974 \\
\hline 764.5 & 2.32 & 0.062 & 2.48 & 0.026 & 0.060 & 0.971 & 2.30 & 0.087 & 2.52 & 0.037 & 0.086 & 0.980 \\
\hline 767.9 & 2.24 & 0.098 & 2.49 & 0.037 & 0.083 & 0.854 & 2.22 & 0.121 & 2.53 & 0.048 & 0.107 & 0.882 \\
\hline 771.4 & 2.30 & 0.076 & 2.49 & 0.028 & 0.066 & 0.867 & 2.28 & 0.101 & 2.53 & 0.040 & 0.091 & 0.901 \\
\hline 774.3 & 2.20 & 0.110 & 2.47 & 0.048 & 0.105 & 0.958 & 2.17 & 0.135 & 2.51 & 0.060 & 0.130 & 0.966 \\
\hline 777.0 & 2.27 & 0.083 & 2.48 & 0.035 & 0.080 & 0.967 & 2.25 & 0.105 & 2.52 & 0.045 & 0.102 & 0.974 \\
\hline 779.7 & 2.27 & 0.089 & 2.49 & 0.032 & 0.072 & 0.813 & 2.25 & 0.107 & 2.52 & 0.040 & 0.091 & 0.846 \\
\hline 794.6 & 2.23 & 0.120 & 2.53 & 0.048 & 0.107 & 0.890 & 2.21 & 0.137 & 2.56 & 0.056 & 0.123 & 0.904 \\
\hline 797.8 & 2.20 & 0.133 & 2.53 & 0.059 & 0.131 & 0.980 & 2.18 & 0.147 & 2.56 & 0.066 & 0.145 & 0.982 \\
\hline 800.8 & 2.19 & 0.135 & 2.53 & 0.056 & 0.122 & 0.906 & 2.17 & 0.151 & 2.56 & 0.064 & 0.139 & 0.916 \\
\hline 804.1 & 2.18 & 0.131 & 2.51 & 0.051 & 0.112 & 0.851 & 2.16 & 0.149 & 2.54 & 0.060 & 0.129 & 0.868 \\
\hline 807.5 & 2.23 & 0.111 & 2.51 & 0.044 & 0.099 & 0.892 & 2.21 & 0.128 & 2.53 & 0.052 & 0.116 & 0.907 \\
\hline 810.5 & 2.26 & 0.092 & 2.49 & 0.034 & 0.078 & 0.842 & 2.24 & 0.112 & 2.52 & 0.044 & 0.098 & 0.870 \\
\hline 814.3 & 2.30 & 0.073 & 2.48 & 0.026 & 0.059 & 0.807 & 2.28 & 0.094 & 2.52 & 0.035 & 0.080 & 0.850 \\
\hline 818.0 & 2.24 & 0.099 & 2.49 & 0.041 & 0.092 & 0.934 & 2.22 & 0.121 & 2.53 & 0.052 & 0.115 & 0.946 \\
\hline 821.7 & 2.28 & 0.078 & 2.48 & 0.032 & 0.073 & 0.931 & 2.26 & 0.104 & 2.52 & 0.044 & 0.098 & 0.948 \\
\hline 825.0 & 2.28 & 0.080 & 2.48 & 0.030 & 0.068 & 0.855 & 2.26 & 0.103 & 2.52 & 0.040 & 0.091 & 0.887 \\
\hline 827.6 & 2.27 & 0.086 & 2.48 & 0.035 & 0.079 & 0.921 & 2.24 & 0.110 & 2.52 & 0.046 & 0.103 & 0.939 \\
\hline 831.1 & 2.27 & 0.083 & 2.47 & 0.034 & 0.076 & 0.922 & 2.24 & 0.113 & 2.52 & 0.048 & 0.107 & 0.943 \\
\hline 834.0 & 2.26 & 0.084 & 2.47 & 0.036 & 0.082 & 0.966 & 2.23 & 0.115 & 2.52 & 0.050 & 0.112 & 0.975 \\
\hline 838.0 & 2.28 & 0.080 & 2.48 & 0.032 & 0.074 & 0.914 & 2.25 & 0.107 & 2.52 & 0.044 & 0.100 & 0.935 \\
\hline 841.2 & 2.24 & 0.096 & 2.48 & 0.038 & 0.085 & 0.889 & 2.22 & 0.120 & 2.52 & 0.049 & 0.109 & 0.911 \\
\hline 843.9 & 2.28 & 0.077 & 2.48 & 0.029 & 0.066 & 0.851 & 2.26 & 0.103 & 2.52 & 0.040 & 0.091 & 0.888 \\
\hline 847.2 & 2.26 & 0.100 & 2.52 & 0.038 & 0.085 & 0.852 & 2.25 & 0.118 & 2.55 & 0.046 & 0.103 & 0.875 \\
\hline 849.6 & 2.18 & 0.135 & 2.52 & 0.048 & 0.104 & 0.775 & 2.16 & 0.149 & 2.54 & 0.055 & 0.119 & 0.797 \\
\hline 853.4 & 2.23 & 0.113 & 2.51 & 0.043 & 0.095 & 0.843 & 2.21 & 0.130 & 2.54 & 0.051 & 0.112 & 0.863 \\
\hline 859.0 & 2.28 & 0.094 & 2.52 & 0.040 & 0.092 & 0.974 & 2.27 & 0.112 & 2.55 & 0.048 & 0.110 & 0.978 \\
\hline
\end{tabular}


Table G-1: Laboratory Material Properties and Water Contents Measured on Core Samples from Drill Hole USW SD-9 (Continued)

[Measurements reported by L.E. Flint, U.S. Geological Survey Hydrologic Research Facility; DTN No. GS950308312231.004. J. Curtis and C. Vidano, analysts. Sample number consists of "SD9-" plus depth in feet]

\begin{tabular}{|c|c|c|c|c|c|c|c|c|c|c|c|c|}
\hline \multirow[b]{2}{*}{$\begin{array}{l}\text { Depth } \\
\text { (feet) }\end{array}$} & \multicolumn{6}{|c|}{ Relative Humidity Oven Dried } & \multicolumn{6}{|c|}{$105^{\circ} \mathrm{C}$ Oven-Drled } \\
\hline & $\begin{array}{l}\text { Dry Bulk } \\
\text { Density } \\
\left(\mathrm{g} / \mathrm{cm}^{3}\right)\end{array}$ & $\begin{array}{l}\text { Porosity } \\
\left(\mathrm{cm}^{3} / \mathrm{cm}^{3}\right)\end{array}$ & $\begin{array}{l}\text { Particle } \\
\text { Density } \\
\left(\mathrm{g} / \mathrm{cm}^{3}\right)\end{array}$ & $\begin{array}{c}\text { Grav. } \\
\text { Water } \\
\text { Content } \\
(\mathbf{g} / \mathbf{g})\end{array}$ & $\begin{array}{c}\text { Vol. } \\
\text { Water } \\
\text { Content } \\
\left(\mathrm{cm}^{3} / \mathrm{cm}^{3}\right)\end{array}$ & $\begin{array}{c}\text { Relative } \\
\text { Satn. }\end{array}$ & $\begin{array}{l}\text { Dry Bulk } \\
\text { Density } \\
\left(\mathrm{g} / \mathrm{cm}^{3}\right)\end{array}$ & $\begin{array}{l}\text { Porosity } \\
\left(\mathrm{cm}^{3} / \mathrm{cm}^{3}\right)\end{array}$ & $\begin{array}{l}\text { Particle } \\
\text { Density } \\
\left(\mathrm{g} / \mathrm{cm}^{3}\right)\end{array}$ & $\begin{array}{c}\text { Grav. } \\
\text { Water } \\
\text { Content } \\
\text { (g/g) }\end{array}$ & $\begin{array}{c}\text { Vol. } \\
\text { Water } \\
\text { Content } \\
\left(\mathrm{cm}^{3} / \mathrm{cm}^{3}\right)\end{array}$ & $\begin{array}{c}\text { Relative } \\
\text { Satn. }\end{array}$ \\
\hline 865.3 & 2.24 & 0.108 & 2.51 & 0.044 & 0.098 & 0.907 & 2.22 & 0.126 & 2.54 & 0.052 & 0.116 & 0.920 \\
\hline 879.6 & 2.31 & 0.102 & 2.57 & 0.045 & 0.104 & 1.020 & 2.30 & 0.117 & 2.60 & 0.052 & 0.119 & 1.017 \\
\hline 888.8 & 2.16 & 0.148 & 2.53 & 0.053 & 0.115 & 0.774 & 2.14 & 0.163 & 2.56 & 0.061 & 0.130 & 0.794 \\
\hline 897.0 & 2.30 & 0.089 & 2.53 & 0.035 & 0.080 & 0.898 & 2.29 & 0.103 & 2.55 & 0.041 & 0.094 & 0.913 \\
\hline 899.5 & 2.30 & 0.096 & 2.54 & 0.036 & 0.082 & 0.854 & 2.28 & 0.113 & 2.57 & 0.044 & 0.099 & 0.877 \\
\hline 905.8 & 2.33 & 0.083 & 2.54 & 0.032 & 0.074 & 0.886 & 2.31 & 0.100 & 2.57 & 0.039 & 0.091 & 0.905 \\
\hline 921.9 & 2.25 & 0.121 & 2.56 & 0.043 & 0.096 & 0.794 & 2.23 & 0.137 & 2.58 & 0.050 & 0.112 & 0.818 \\
\hline 924.2 & 2.20 & 0.136 & 2.54 & 0.044 & 0.098 & 0.717 & 2.18 & 0.150 & 2.57 & 0.051 & 0.112 & 0.743 \\
\hline 936.1 & 2.16 & 0.160 & 2.57 & 0.054 & 0.116 & 0.728 & 2.15 & 0.173 & 2.59 & 0.060 & 0.129 & 0.748 \\
\hline 938.9 & 2.25 & 0.113 & 2.54 & 0.041 & 0.092 & 0.812 & 2.24 & 0.127 & 2.57 & 0.047 & 0.106 & 0.833 \\
\hline 944.6 & 2.22 & 0.125 & 2.54 & 0.044 & 0.099 & 0.787 & 2.20 & 0.139 & 2.56 & 0.051 & 0.113 & 0.809 \\
\hline 948.0 & 2.22 & 0.118 & 2.52 & 0.042 & 0.094 & 0.796 & 2.21 & 0.134 & 2.55 & 0.050 & 0.110 & 0.821 \\
\hline 954.0 & 2.35 & 0.074 & 2.53 & 0.027 & 0.064 & 0.865 & 2.33 & 0.093 & 2.57 & 0.036 & 0.083 & 0.893 \\
\hline 958.1 & 2.20 & 0.129 & 2.53 & 0.045 & 0.100 & 0.776 & 2.18 & 0.145 & 2.55 & 0.053 & 0.116 & 0.801 \\
\hline 962.6 & 2.35 & 0.071 & 2.53 & 0.024 & 0.056 & 0.791 & 2.33 & 0.090 & 2.56 & 0.032 & 0.075 & 0.835 \\
\hline 968.7 & 2.23 & 0.109 & 2.50 & 0.041 & 0.091 & 0.837 & 2.21 & 0.127 & 2.54 & 0.049 & 0.109 & 0.860 \\
\hline 971.9 & 2.28 & 0.095 & 2.52 & 0.030 & 0.068 & 0.716 & 2.26 & 0.114 & 2.55 & 0.039 & 0.087 & 0.764 \\
\hline 975.5 & 2.26 & 0.096 & 2.50 & 0.038 & 0.087 & 0.910 & 2.25 & 0.114 & 2.53 & 0.047 & 0.106 & 0.925 \\
\hline 981.0 & 2.21 & 0.120 & 2.51 & 0.043 & 0.095 & 0.793 & 2.19 & 0.137 & 2.54 & 0.051 & 0.112 & 0.819 \\
\hline 984.7 & 2.20 & 0.120 & 2.50 & 0.041 & 0.089 & 0.742 & 2.19 & 0.138 & 2.53 & 0.049 & 0.107 & 0.775 \\
\hline 986.6 & 2.19 & 0.126 & 2.50 & 0.043 & 0.094 & 0.744 & 2.17 & 0.144 & 2.53 & 0.052 & 0.112 & 0.776 \\
\hline 995.7 & 2.17 & 0.131 & 2.50 & 0.049 & 0.106 & 0.809 & 2.16 & 0.148 & 2.53 & 0.057 & 0.123 & 0.832 \\
\hline 1003.0 & 2.12 & 0.153 & 2.50 & 0.049 & 0.103 & 0.672 & 2.10 & 0.170 & 2.53 & 0.057 & 0.120 & 0.704 \\
\hline 1007.3 & 2.25 & 0.102 & 2.51 & 0.035 & 0.079 & 0.781 & 2.23 & 0.121 & 2.54 & 0.044 & 0.099 & 0.816 \\
\hline 1012.3 & 2.18 & 0.140 & 2.53 & 0.047 & 0.102 & 0.731 & 2.16 & 0.156 & 2.56 & 0.055 & 0.119 & 0.759 \\
\hline 1017.2 & 2.31 & 0.085 & 2.53 & 0.033 & 0.076 & 0.886 & 2.29 & 0.104 & 2.56 & 0.041 & 0.094 & 0.906 \\
\hline 1023.8 & 2.30 & 0.087 & 2.52 & 0.034 & 0.078 & 0.890 & 2.28 & 0.104 & 2.55 & 0.041 & 0.094 & 0.908 \\
\hline 1028.9 & 2.26 & 0.111 & 2.54 & 0.040 & 0.090 & 0.810 & 2.24 & 0.128 & 2.57 & 0.048 & 0.107 & 0.834 \\
\hline 1033.1 & 2.30 & 0.095 & 2.54 & 0.037 & 0.086 & 0.903 & 2.28 & 0.112 & 2.57 & 0.045 & 0.103 & 0.917 \\
\hline 1035.1 & 2.21 & 0.126 & 2.53 & 0.052 & 0.116 & 0.922 & 2.20 & 0.142 & 2.56 & 0.060 & 0.132 & 0.931 \\
\hline 1038.8 & 2.28 & 0.100 & 2.54 & 0.042 & 0.095 & 0.950 & 2.27 & 0.117 & 2.57 & 0.050 & 0.112 & 0.957 \\
\hline
\end{tabular}


Table G-1: Laboratory Material Properties and Water Contents Measured on Core Samples from Drill Hole USW SD-9 (Continued)

[Measurements reported by L.E. Flint, U.S. Geological Survey Hydrologic Research Facility; DTN No. GS950308312231.004. J. Curtis and C. Vidano, analysts. Sample number consists of "SD9-" plus depth in feet]

\begin{tabular}{|c|c|c|c|c|c|c|c|c|c|c|c|c|}
\hline \multirow[b]{2}{*}{$\begin{array}{l}\text { Depth } \\
\text { (feet) }\end{array}$} & \multicolumn{6}{|c|}{ Relative Humidity Oven Dried } & \multicolumn{6}{|c|}{$105^{\circ} \mathrm{C}$ Oven-Dried } \\
\hline & $\begin{array}{c}\text { Dry Bulk } \\
\text { Density } \\
\text { (g/cm³) }\end{array}$ & $\begin{array}{l}\text { Porosity } \\
\left(\mathrm{cm}^{2} / \mathrm{cm}^{\prime}\right)\end{array}$ & $\begin{array}{l}\text { Particle } \\
\text { Density } \\
\left.\text { (g/ } \mathrm{cm}^{3}\right)\end{array}$ & $\begin{array}{c}\text { Grav. } \\
\text { Water } \\
\text { Content } \\
(\mathbf{g} / g)\end{array}$ & $\begin{array}{c}\text { Vol. } \\
\text { Water } \\
\text { Content } \\
\left(\mathrm{cm}^{3} / \mathrm{cm}^{3}\right)\end{array}$ & $\begin{array}{c}\text { Relative } \\
\text { Satn. }\end{array}$ & $\begin{array}{l}\text { Dry Bulk } \\
\text { Density } \\
\left(\mathrm{g} / \mathrm{cm}^{3}\right)\end{array}$ & $\begin{array}{l}\text { Porosity } \\
\left(\mathrm{cm}^{7} / \mathrm{cm}^{\top}\right)\end{array}$ & $\begin{array}{l}\text { Particle } \\
\text { Density } \\
\left(\mathrm{g} / \mathrm{cm}^{\prime}\right)\end{array}$ & $\begin{array}{c}\text { Grav. } \\
\text { Water } \\
\text { Content } \\
\text { (g/g) }\end{array}$ & $\begin{array}{c}\text { Vol. } \\
\text { Water } \\
\text { Content } \\
\left(\mathrm{cm}^{2} / \mathrm{cm}^{2}\right)\end{array}$ & $\begin{array}{c}\text { Relative } \\
\text { Satn. }\end{array}$ \\
\hline 1041.0 & 2.25 & 0.113 & 2.54 & 0.045 & 0.102 & 0.895 & 2.23 & 0.130 & 2.57 & 0.053 & 0.118 & 0.908 \\
\hline 1044.2 & 2.27 & 0.101 & 2.53 & 0.039 & 0.088 & 0.874 & 2.26 & 0.118 & 2.56 & 0.047 & 0.105 & 0.892 \\
\hline 1047.2 & 2.29 & 0.096 & 2.53 & 0.039 & 0.089 & 0.932 & 2.27 & 0.112 & 2.56 & 0.047 & 0.106 & 0.942 \\
\hline 1050.2 & 2.29 & 0.099 & 2.54 & 0.038 & 0.086 & 0.871 & 2.27 & 0.115 & 2.57 & 0.045 & 0.103 & 0.889 \\
\hline 1053.6 & 2.32 & 0.087 & 2.54 & 0.037 & 0.086 & 0.985 & 2.30 & 0.105 & 2.57 & 0.045 & 0.104 & 0.987 \\
\hline 1055.8 & 2.31 & 0.087 & 2.53 & 0.034 & 0.079 & 0.909 & 2.29 & 0.105 & 2.56 & 0.042 & 0.097 & 0.924 \\
\hline 1064.8 & 2.29 & 0.091 & 2.52 & 0.038 & 0.087 & 0.958 & 2.28 & 0.109 & 2.55 & 0.046 & 0.105 & 0.965 \\
\hline 1068.1 & 2.21 & 0.126 & 2.53 & 0.046 & 0.101 & 0.798 & 2.19 & 0.142 & 2.56 & 0.053 & 0.117 & 0.821 \\
\hline 1070.4 & 2.05 & 0.193 & 2.54 & 0.077 & 0.158 & 0.821 & 2.04 & 0.206 & 2.57 & 0.084 & 0.171 & 0.833 \\
\hline 1076.7 & 2.32 & 0.089 & 2.54 & 0.035 & 0.082 & 0.920 & 2.30 & 0.106 & 2.57 & 0.043 & 0.099 & 0.933 \\
\hline 1080.1 & 2.31 & 0.090 & 2.54 & 0.032 & 0.075 & 0.837 & 2.30 & 0.107 & 2.57 & 0.040 & 0.092 & 0.863 \\
\hline 1086.4 & 2.32 & 0.091 & 2.56 & 0.036 & 0.084 & 0.918 & 2.31 & 0.107 & 2.59 & 0.043 & 0.100 & 0.930 \\
\hline 1091.1 & 2.30 & 0.103 & 2.56 & 0.039 & 0.089 & 0.863 & 2.28 & 0.118 & 2.59 & 0.046 & 0.104 & 0.881 \\
\hline 1095.4 & 2.33 & 0.085 & 2.55 & 0.031 & 0.071 & 0.840 & 2.31 & 0.105 & 2.58 & 0.039 & 0.091 & 0.870 \\
\hline 1098.4 & 2.21 & 0.128 & 2.53 & 0.041 & 0.091 & 0.712 & 2.19 & 0.145 & 2.56 & 0.049 & 0.108 & 0.744 \\
\hline 1101.3 & 2.19 & 0.133 & 2.52 & 0.046 & 0.100 & 0.757 & 2.17 & 0.148 & 2.55 & 0.053 & 0.115 & 0.781 \\
\hline 1104.1 & 2.10 & 0.169 & 2.53 & 0.048 & 0.101 & 0.596 & 2.09 & 0.183 & 2.55 & 0.055 & 0.114 & 0.625 \\
\hline 1106.4 & 2.27 & 0.105 & 2.53 & 0.035 & 0.080 & 0.761 & 2.25 & 0.121 & 2.56 & 0.043 & 0.096 & 0.793 \\
\hline 1110.3 & 2.18 & 0.140 & 2.53 & 0.047 & 0.102 & 0.729 & 2.16 & 0.155 & 2.56 & 0.054 & 0.117 & 0.755 \\
\hline 1113.5 & 2.19 & 0.134 & 2.53 & 0.043 & 0.094 & 0.706 & 2.17 & 0.150 & 2.56 & 0.051 & 0.110 & 0.737 \\
\hline 1116.0 & 2.18 & 0.138 & 2.53 & 0.048 & 0.104 & 0.749 & 2.16 & 0.154 & 2.55 & 0.055 & 0.119 & 0.775 \\
\hline 1119.2 & 2.16 & 0.143 & 2.52 & 0.050 & 0.108 & 0.755 & 2.15 & 0.158 & 2.55 & 0.057 & 0.123 & 0.778 \\
\hline 1125.1 & 2.09 & 0.177 & 2.54 & 0.068 & 0.142 & 0.806 & 2.08 & 0.190 & 2.56 & 0.075 & 0.156 & 0.819 \\
\hline 1128.6 & 2.20 & 0.130 & 2.53 & 0.052 & 0.114 & 0.877 & 2.19 & 0.145 & 2.56 & 0.059 & 0.129 & 0.890 \\
\hline 1133.6 & 2.24 & 0.113 & 2.53 & 0.040 & 0.090 & 0.799 & 2.23 & 0.129 & 2.56 & 0.048 & 0.107 & 0.825 \\
\hline 1139.6 & 2.20 & 0.131 & 2.53 & 0.050 & 0.110 & 0.840 & 2.19 & 0.146 & 2.56 & 0.057 & 0.125 & 0.856 \\
\hline 1142.0 & 2.24 & 0.116 & 2.53 & 0.047 & 0.105 & 0.903 & 2.22 & 0.131 & 2.56 & 0.054 & 0.120 & 0.914 \\
\hline 1146.1 & 2.24 & 0.114 & 2.53 & 0.044 & 0.098 & 0.863 & 2.22 & 0.130 & 2.56 & 0.052 & 0.115 & 0.880 \\
\hline 1149.0 & 2.33 & 0.076 & 2.52 & 0.028 & 0.065 & 0.865 & 2.31 & 0.094 & 2.55 & 0.036 & 0.083 & 0.891 \\
\hline 1152.7 & 2.25 & 0.111 & 2.53 & 0.042 & 0.095 & 0.855 & 2.23 & 0.127 & 2.56 & 0.050 & 0.111 & 0.874 \\
\hline 1158.5 & 2.22 & 0.120 & 2.53 & 0.037 & 0.083 & 0.690 & 2.21 & 0.135 & 2.55 & 0.044 & 0.098 & 0.724 \\
\hline
\end{tabular}


Table G-1: Laboratory Material Properties and Water Contents Measured on Core Samples from Drill Hole USW SD-9 (Continued)

[Measurements reported by L.E. Flint, U.S. Geological Survey Hydrologic Research Facility; DTN No. GS950308312231.004. J. Curtis and C. Vidano, analysts. Sample number consists of "SD9-" plus depth in feet]

\begin{tabular}{|c|c|c|c|c|c|c|c|c|c|c|c|c|}
\hline \multirow[b]{2}{*}{$\begin{array}{l}\text { Depth } \\
\text { (feet) }\end{array}$} & \multicolumn{6}{|c|}{ Relative Humidity Oven Dried } & \multicolumn{6}{|c|}{$105^{\circ} \mathrm{C}$ Oven-Dried } \\
\hline & $\begin{array}{l}\text { Dry Bulk } \\
\text { Density } \\
\left(\mathrm{g} / \mathrm{cm}^{3}\right)\end{array}$ & $\begin{array}{l}\text { Porosity } \\
\left(\mathrm{cm}^{1} / \mathrm{cm}^{3}\right)\end{array}$ & $\begin{array}{l}\text { Particle } \\
\text { Density } \\
\text { (g/cm })\end{array}$ & $\begin{array}{c}\text { Grav. } \\
\text { Water } \\
\text { Content } \\
(g / g)\end{array}$ & $\begin{array}{c}\text { Vol. } \\
\text { Water } \\
\text { Content } \\
\left(\mathrm{cm}^{3} / \mathrm{cm}^{3}\right)\end{array}$ & $\begin{array}{c}\text { Relative } \\
\text { Satn. }\end{array}$ & $\begin{array}{l}\text { Dry Bulk } \\
\text { Density } \\
\left(\mathrm{g} / \mathrm{cm}^{3}\right)\end{array}$ & $\begin{array}{c}\text { Porosity } \\
\left(\mathrm{cm}^{3} / \mathrm{cm}^{3}\right)\end{array}$ & $\begin{array}{l}\text { Particle } \\
\text { Density } \\
\left(\mathrm{g} / \mathrm{cm}^{3}\right)\end{array}$ & $\begin{array}{c}\text { Grav. } \\
\text { Water } \\
\text { Content } \\
(\mathbf{g} / \mathbf{g})\end{array}$ & $\begin{array}{c}\text { Vol. } \\
\text { Water } \\
\text { Content } \\
\left(\mathrm{cm}^{3} / \mathrm{cm}^{3}\right)\end{array}$ & $\begin{array}{c}\text { Relative } \\
\text { Satn. }\end{array}$ \\
\hline 1161.1 & 2.20 & 0.126 & 2.52 & 0.049 & 0.109 & 0.864 & 2.18 & 0.141 & 2.54 & 0.057 & 0.124 & 0.879 \\
\hline 1163.8 & 2.26 & 0.100 & 2.51 & 0.037 & 0.083 & 0.828 & 2.24 & 0.117 & 2.54 & 0.044 & 0.100 & 0.853 \\
\hline 1166.6 & 2.23 & 0.112 & 2.51 & 0.043 & 0.096 & 0.862 & 2.22 & 0.128 & 2.54 & 0.051 & 0.112 & 0.879 \\
\hline 1170.5 & 2.20 & 0.140 & 2.56 & 0.052 & 0.114 & 0.813 & 2.19 & 0.153 & 2.58 & 0.058 & 0.127 & 0.830 \\
\hline 1172.8 & 2.32 & 0.092 & 2.55 & 0.035 & 0.081 & 0.880 & 2.30 & 0.113 & 2.59 & 0.045 & 0.103 & 0.903 \\
\hline 1179.0 & 2.29 & 0.103 & 2.55 & 0.039 & 0.090 & 0.868 & 2.26 & 0.124 & 2.58 & 0.049 & 0.110 & 0.890 \\
\hline 1186.2 & 2.28 & 0.113 & 2.57 & 0.038 & 0.086 & 0.758 & 2.26 & 0.129 & 2.59 & 0.045 & 0.101 & 0.787 \\
\hline 1189.1 & 2.30 & 0.104 & 2.56 & 0.037 & 0.086 & 0.827 & 2.28 & 0.120 & 2.59 & 0.045 & 0.102 & 0.850 \\
\hline 1193.6 & 2.32 & 0.091 & 2.55 & 0.035 & 0.081 & 0.886 & 2.30 & 0.114 & 2.60 & 0.045 & 0.104 & 0.908 \\
\hline 1200.2 & 2.21 & 0.137 & 2.56 & 0.050 & 0.111 & 0.812 & 2.20 & 0.151 & 2.58 & 0.057 & 0.125 & 0.829 \\
\hline 1203.0 & 2.34 & 0.082 & 2.55 & 0.032 & 0.074 & 0.906 & 2.32 & 0.105 & 2.59 & 0.042 & 0.097 & 0.926 \\
\hline 1208.4 & 2.32 & 0.083 & 2.54 & 0.032 & 0.073 & 0.878 & 2.30 & 0.102 & 2.57 & 0.040 & 0.092 & 0.901 \\
\hline 1211.9 & 2.33 & 0.089 & 2.56 & 0.034 & 0.080 & 0.906 & 2.31 & 0.106 & 2.59 & 0.042 & 0.098 & 0.921 \\
\hline 1215.0 & 2.32 & 0.091 & 2.55 & 0.034 & 0.079 & 0.876 & 2.30 & 0.111 & 2.58 & 0.043 & 0.100 & 0.899 \\
\hline 1220.6 & 2.19 & 0.142 & 2.55 & 0.056 & 0.123 & 0.864 & 2.17 & 0.159 & 2.58 & 0.064 & 0.139 & 0.878 \\
\hline 1224.4 & 2.33 & 0.089 & 2.56 & 0.033 & 0.077 & 0.867 & 2.31 & 0.111 & 2.59 & 0.043 & 0.099 & 0.893 \\
\hline 1229.8 & 2.32 & 0.095 & 2.57 & 0.033 & 0.077 & 0.805 & 2.31 & 0.111 & 2.59 & 0.040 & 0.093 & 0.834 \\
\hline 1233.2 & 2.15 & 0.161 & 2.56 & 0.072 & 0.154 & 0.959 & 2.14 & 0.175 & 2.59 & 0.079 & 0.169 & 0.963 \\
\hline 1235.5 & 2.28 & 0.110 & 2.56 & 0.037 & 0.084 & 0.764 & 2.26 & 0.128 & 2.59 & 0.045 & 0.102 & 0.796 \\
\hline 1242.0 & 2.16 & 0.154 & 2.55 & 0.053 & 0.115 & 0.745 & 2.14 & 0.170 & 2.58 & 0.061 & 0.131 & 0.769 \\
\hline 1244.6 & 2.33 & 0.084 & 2.54 & 0.031 & 0.072 & 0.865 & 2.31 & 0.104 & 2.58 & 0.040 & 0.093 & 0.892 \\
\hline 1250.7 & 2.37 & 0.069 & 2.55 & 0.026 & 0.061 & 0.886 & 2.35 & 0.093 & 2.59 & 0.036 & 0.085 & 0.916 \\
\hline 1253.8 & 2.27 & 0.105 & 2.54 & 0.036 & 0.081 & 0.777 & 2.25 & 0.125 & 2.57 & 0.045 & 0.102 & 0.813 \\
\hline 1257.0 & 2.34 & 0.077 & 2.54 & 0.029 & 0.067 & 0.869 & 2.32 & 0.099 & 2.57 & 0.038 & 0.089 & 0.898 \\
\hline 1262.6 & 2.33 & 0.084 & 2.54 & 0.027 & 0.063 & 0.751 & 2.31 & 0.102 & 2.57 & 0.035 & 0.082 & 0.797 \\
\hline 1269.2 & 2.37 & 0.067 & 2.54 & 0.025 & 0.059 & 0.874 & 2.34 & 0.091 & 2.58 & 0.035 & 0.083 & 0.907 \\
\hline 1272.1 & 2.35 & 0.075 & 2.54 & 0.028 & 0.066 & 0.873 & 2.33 & 0.099 & 2.59 & 0.038 & 0.090 & 0.904 \\
\hline 1274.8 & 2.35 & 0.078 & 2.55 & 0.028 & 0.065 & 0.837 & 2.32 & 0.102 & 2.59 & 0.038 & 0.089 & 0.875 \\
\hline 1278.3 & 2.35 & 0.080 & 2.55 & 0.028 & 0.065 & 0.818 & 2.32 & 0.104 & 2.59 & 0.039 & 0.090 & 0.861 \\
\hline 1281.6 & 2.35 & 0.074 & 2.54 & 0.028 & 0.066 & 0.893 & 2.33 & 0.098 & 2.58 & 0.039 & 0.090 & 0.919 \\
\hline 1284.8 & 2.24 & 0.117 & 2.54 & 0.040 & 0.090 & 0.769 & 2.22 & 0.136 & 2.57 & 0.049 & 0.109 & 0.801 \\
\hline
\end{tabular}


Table G-1: Laboratory Material Properties and Water Contents Measured on Core Samples from Drill Hole USW SD-9 (Continued)

[Measurements reported by L.E. Flint, U.S. Geological Survey Hydrologic Research Facility; DTN No. GS950308312231.004. J. Curtis and C. Vidano, analysts. Sample number consists of "SD9-" plus depth in feet]

\begin{tabular}{|c|c|c|c|c|c|c|c|c|c|c|c|c|}
\hline \multirow[b]{2}{*}{$\begin{array}{l}\text { Depth } \\
\text { (feet) }\end{array}$} & \multicolumn{6}{|c|}{ Relative Humidity Oven Dried } & \multicolumn{6}{|c|}{$105^{\circ} \mathrm{C}$ Oven-Dried } \\
\hline & $\begin{array}{l}\text { Dry Bulk } \\
\text { Density } \\
\text { (g/cm³) }\end{array}$ & $\begin{array}{l}\text { Porosity } \\
\left(\mathrm{cm}^{3} / \mathrm{cm}^{3}\right)\end{array}$ & $\begin{array}{c}\text { Particle } \\
\text { Density } \\
\left(\mathrm{g} / \mathrm{cm}^{3}\right)\end{array}$ & $\begin{array}{c}\text { Grav. } \\
\text { Water } \\
\text { Content } \\
(\mathbf{g} / \mathbf{g})\end{array}$ & $\begin{array}{c}\text { Vol. } \\
\text { Water } \\
\text { Content } \\
\left(\mathrm{cm}^{3} / \mathrm{cm}^{3}\right)\end{array}$ & $\begin{array}{c}\text { Relative } \\
\text { Satn. }\end{array}$ & $\begin{array}{l}\text { Dry Bulk } \\
\text { Density } \\
\text { (g/cm') }\end{array}$ & $\begin{array}{l}\text { Porosity } \\
\left(\mathrm{cm}^{3} / \mathrm{cm}^{3}\right)\end{array}$ & $\begin{array}{l}\text { Particle } \\
\text { Density } \\
\text { ( }\left(\mathrm{g} / \mathrm{cm}^{3}\right)\end{array}$ & $\begin{array}{c}\text { Grav. } \\
\text { Water } \\
\text { Content } \\
(g / g)\end{array}$ & $\begin{array}{c}\text { Vol. } \\
\text { Water } \\
\text { Content } \\
\left(\mathrm{cm}^{3} / \mathrm{cm}^{3}\right)\end{array}$ & $\begin{array}{c}\text { Relative } \\
\text { Satn. }\end{array}$ \\
\hline 1289.9 & 2.38 & 0.065 & 2.55 & 0.024 & 0.056 & 0.860 & 2.36 & 0.085 & 2.58 & 0.032 & 0.076 & 0.892 \\
\hline 1296.2 & 2.36 & 0.071 & 2.54 & 0.027 & 0.065 & 0.910 & 2.34 & 0.092 & 2.57 & 0.036 & 0.085 & 0.930 \\
\hline 1299.8 & 2.33 & 0.077 & 2.53 & 0.029 & 0.068 & 0.882 & 2.31 & 0.102 & 2.57 & 0.040 & 0.092 & 0.910 \\
\hline 1302.5 & 2.37 & 0.062 & 2.53 & 0.024 & 0.058 & 0.935 & 2.35 & 0.084 & 2.57 & 0.034 & 0.080 & 0.953 \\
\hline 1304.9 & 2.34 & 0.079 & 2.54 & 0.031 & 0.072 & 0.917 & 2.31 & 0.103 & 2.58 & 0.042 & 0.096 & 0.936 \\
\hline 1308.4 & 2.29 & 0.096 & 2.53 & 0.041 & 0.094 & 0.976 & 2.26 & 0.124 & 2.58 & 0.054 & 0.121 & 0.981 \\
\hline 1311.1 & 2.30 & 0.085 & 2.52 & 0.038 & 0.087 & 1.020 & 2.28 & 0.112 & 2.56 & 0.050 & 0.114 & 1.015 \\
\hline 1317.3 & 2.24 & 0.101 & 2.49 & 0.028 & 0.063 & 0.620 & 2.22 & 0.118 & 2.52 & 0.036 & 0.080 & 0.674 \\
\hline 1320.3 & 2.36 & 0.061 & 2.52 & 0.023 & 0.054 & 0.886 & 2.34 & 0.082 & 2.55 & 0.032 & 0.075 & 0.914 \\
\hline 1323.4 & 2.31 & 0.078 & 2.50 & 0.032 & 0.074 & 0.958 & 2.28 & 0.104 & 2.55 & 0.044 & 0.101 & 0.969 \\
\hline 1331.9 & 2.31 & 0.077 & 2.50 & 0.032 & 0.074 & 0.962 & 2.29 & 0.099 & 2.54 & 0.042 & 0.096 & 0.971 \\
\hline 1335.1 & 2.35 & 0.066 & 2.51 & 0.029 & 0.069 & 1.034 & 2.32 & 0.090 & 2.55 & 0.040 & 0.092 & 1.025 \\
\hline 1337.6 & 2.23 & 0.103 & 2.49 & 0.042 & 0.093 & 0.907 & 2.21 & 0.127 & 2.53 & 0.053 & 0.117 & 0.925 \\
\hline 1347.6 & 2.32 & 0.069 & 2.49 & 0.024 & 0.056 & 0.821 & 2.30 & 0.092 & 2.53 & 0.035 & 0.080 & 0.866 \\
\hline 1349.6 & 2.41 & 0.043 & 2.52 & 0.016 & 0.039 & 0.904 & 2.39 & 0.065 & 2.56 & 0.025 & 0.061 & 0.936 \\
\hline 1352.4 & 2.31 & 0.067 & 2.48 & 0.026 & 0.060 & 0.888 & 2.29 & 0.088 & 2.51 & 0.035 & 0.081 & 0.915 \\
\hline 1355.2 & 2.31 & 0.064 & 2.47 & 0.024 & 0.055 & 0.856 & 2.28 & 0.091 & 2.51 & 0.036 & 0.081 & 0.897 \\
\hline 1358.7 & 2.30 & 0.073 & 2.48 & 0.028 & 0.065 & 0.891 & 2.27 & 0.095 & 2.51 & 0.038 & 0.087 & 0.917 \\
\hline 1361.6 & 2.27 & 0.101 & 2.53 & 0.038 & 0.087 & 0.867 & 2.26 & 0.114 & 2.55 & 0.045 & 0.101 & 0.883 \\
\hline 1365.2 & 2.31 & 0.019 & 2.36 & 0.008 & 0.018 & 0.932 & 2.28 & 0.047 & 2.40 & 0.020 & 0.045 & 0.972 \\
\hline 1368.0 & 2.36 & 0.007 & 2.38 & 0.002 & 0.005 & 0.723 & 2.35 & 0.013 & 2.38 & 0.005 & 0.011 & 0.855 \\
\hline 1370.6 & 2.35 & 0.014 & 2.38 & 0.005 & 0.012 & 0.875 & 2.35 & 0.014 & 2.38 & 0.005 & 0.012 & 0.873 \\
\hline 1374.3 & 2.35 & 0.010 & 2.38 & 0.003 & 0.008 & 0.725 & 2.35 & 0.016 & 2.38 & 0.006 & 0.013 & 0.819 \\
\hline 1377.5 & 2.36 & 0.007 & 2.38 & 0.002 & 0.005 & 0.686 & 2.35 & 0.013 & 2.38 & 0.004 & 0.011 & 0.823 \\
\hline 1380.3 & 2.36 & 0.009 & 2.38 & 0.003 & 0.007 & 0.815 & 2.35 & 0.015 & 2.39 & 0.006 & 0.014 & 0.891 \\
\hline 1382.0 & 2.36 & 0.007 & 2.38 & 0.002 & 0.005 & 0.704 & 2.36 & 0.012 & 2.38 & 0.004 & 0.010 & 0.833 \\
\hline 1385.9 & 2.36 & 0.008 & 2.38 & 0.003 & 0.008 & 0.991 & 2.35 & 0.015 & 2.39 & 0.006 & 0.015 & 0.995 \\
\hline 1388.3 & 2.36 & 0.006 & 2.38 & 0.002 & 0.004 & 0.679 & 2.36 & 0.011 & 2.38 & 0.004 & 0.009 & 0.824 \\
\hline 1392.2 & 2.34 & 0.010 & 2.37 & 0.003 & 0.007 & 0.678 & 2.34 & 0.016 & 2.38 & 0.006 & 0.013 & 0.798 \\
\hline 1394.7 & 2.36 & 0.007 & 2.38 & 0.002 & 0.005 & 0.776 & 2.36 & 0.011 & 2.38 & 0.004 & 0.010 & 0.858 \\
\hline 1401.1 & 2.36 & 0.009 & 2.38 & 0.002 & 0.005 & 0.500 & 2.35 & 0.014 & 2.38 & 0.004 & 0.009 & 0.668 \\
\hline
\end{tabular}


Table G-1: Laboratory Material Properties and Water Contents Measured on Core Samples from Drill Hole USW SD-9 (Continued)

[Measurements reported by L.E. Flint, U.S. Geological Survey Hydrologic Research Facility; DTN No. GS950308312231.004. J. Curtis and C. Vidano, analysts. Sample number consists of "SD9-" plus depth in feet]

\begin{tabular}{|c|c|c|c|c|c|c|c|c|c|c|c|c|}
\hline \multirow[b]{2}{*}{$\begin{array}{l}\text { Depth } \\
\text { (feet) }\end{array}$} & \multicolumn{6}{|c|}{ Relative Humidity Oven Dried } & \multicolumn{6}{|c|}{$105^{\circ} \mathrm{C}$ Oven-Dried } \\
\hline & $\begin{array}{l}\text { Dry Bulk } \\
\text { Density } \\
\text { (g/cm') }\end{array}$ & $\begin{array}{l}\text { Porosity } \\
\left(\mathrm{cm}^{1} / \mathrm{cm}^{3}\right)\end{array}$ & $\begin{array}{l}\text { Particle } \\
\text { Density } \\
\text { (g/cm })\end{array}$ & $\begin{array}{c}\text { Grav. } \\
\text { Water } \\
\text { Content } \\
\text { (g/g) }\end{array}$ & $\begin{array}{c}\text { Vol. } \\
\text { Water } \\
\text { Content } \\
\left(\mathrm{cm}^{3} / \mathrm{cm}^{3}\right)\end{array}$ & $\begin{array}{c}\text { Relative } \\
\text { Satn. }\end{array}$ & $\begin{array}{l}\text { Dry Bulk } \\
\text { Density } \\
\text { (g/cm })\end{array}$ & $\begin{array}{l}\text { Porosity } \\
\left(\mathrm{cm}^{3} / \mathrm{cm}^{3}\right)\end{array}$ & $\begin{array}{l}\text { Particle } \\
\text { Density } \\
\left(\mathrm{g} / \mathrm{cm}^{3}\right)\end{array}$ & $\begin{array}{c}\text { Grav. } \\
\text { Water } \\
\text { Content } \\
(\mathbf{g} / \mathbf{g})\end{array}$ & $\begin{array}{c}\text { Vol. } \\
\text { Water } \\
\text { Content } \\
\left(\mathrm{cm}^{3} / \mathrm{cm}^{3}\right)\end{array}$ & $\begin{array}{c}\text { Relative } \\
\text { Satn. }\end{array}$ \\
\hline 1403.5 & 2.34 & 0.008 & 2.36 & 0.002 & 0.005 & 0.646 & 2.33 & 0.015 & 2.37 & 0.005 & 0.012 & 0.799 \\
\hline 1406.6 & 2.33 & 0.015 & 2.36 & 0.005 & 0.011 & 0.761 & 2.32 & 0.022 & 2.38 & 0.008 & 0.019 & 0.844 \\
\hline 1410.1 & 2.33 & 0.015 & 2.37 & 0.005 & 0.011 & 0.726 & 2.32 & 0.023 & 2.38 & 0.008 & 0.019 & 0.830 \\
\hline 1412.7 & 2.33 & 0.014 & 2.36 & 0.004 & 0.010 & 0.722 & 2.32 & 0.025 & 2.38 & 0.009 & 0.021 & 0.844 \\
\hline 1415.5 & 2.32 & 0.014 & 2.36 & 0.005 & 0.012 & 0.811 & 2.31 & 0.027 & 2.37 & 0.010 & 0.024 & 0.897 \\
\hline 1418.5 & 2.26 & 0.036 & 2.34 & 0.012 & 0.028 & 0.764 & 2.24 & 0.054 & 2.37 & 0.020 & 0.046 & 0.842 \\
\hline 1425.3 & 1.94 & 0.132 & 2.23 & 0.040 & 0.079 & 0.594 & 1.89 & 0.177 & 2.30 & 0.065 & 0.123 & 0.696 \\
\hline 1427.4 & 1.84 & 0.176 & 2.23 & 0.059 & 0.108 & 0.612 & 1.81 & 0.204 & 2.27 & 0.075 & 0.135 & 0.665 \\
\hline 1430.9 & 1.64 & 0.266 & 2.24 & 0.067 & 0.111 & 0.416 & 1.60 & 0.308 & 2.31 & 0.095 & 0.152 & 0.495 \\
\hline 1433.4 & 2.01 & 0.053 & 2.12 & 0.019 & 0.037 & 0.708 & 1.90 & 0.158 & 2.26 & 0.075 & 0.143 & 0.903 \\
\hline 1437.3 & 2.31 & 0.028 & 2.38 & 0.010 & 0.023 & 0.846 & 2.31 & 0.031 & 2.38 & 0.011 & 0.026 & 0.861 \\
\hline 1440.2 & 1.89 & 0.181 & 2.30 & 0.066 & 0.125 & 0.687 & 1.85 & 0.222 & 2.37 & 0.089 & 0.165 & 0.744 \\
\hline 1443.3 & 1.53 & 0.322 & 2.26 & 0.117 & 0.180 & 0.559 & 1.47 & 0.385 & 2.39 & 0.166 & 0.244 & 0.632 \\
\hline 1445.2 & 1.75 & 0.219 & 2.24 & 0.092 & 0.161 & 0.735 & 1.70 & 0.271 & 2.33 & 0.126 & 0.213 & 0.786 \\
\hline 1448.5 & 1.56 & 0.305 & 2.24 & 0.118 & 0.183 & 0.602 & 1.51 & 0.349 & 2.33 & 0.151 & 0.228 & 0.653 \\
\hline 1450.9 & 1.44 & 0.375 & 2.30 & 0.155 & 0.222 & 0.592 & 1.40 & 0.410 & 2.37 & 0.183 & 0.257 & 0.626 \\
\hline 1454.2 & 1.51 & 0.326 & 2.24 & 0.196 & 0.296 & 0.907 & 1.45 & 0.389 & 2.37 & 0.248 & 0.359 & 0.922 \\
\hline 1458.2 & 1.73 & 0.177 & 2.10 & 0.099 & 0.171 & 0.966 & 1.60 & 0.301 & 2.29 & 0.184 & 0.295 & 0.980 \\
\hline 1460.2 & 1.70 & 0.213 & 2.16 & 0.119 & 0.202 & 0.947 & 1.58 & 0.332 & 2.37 & 0.203 & 0.321 & 0.966 \\
\hline 1463.0 & 1.74 & 0.185 & 2.13 & 0.105 & 0.183 & 0.988 & 1.61 & 0.314 & 2.34 & 0.194 & 0.312 & 0.993 \\
\hline 1467.0 & 1.54 & 0.297 & 2.20 & 0.185 & 0.285 & 0.960 & 1.44 & 0.400 & 2.40 & 0.269 & 0.388 & 0.970 \\
\hline 1467.9 & 1.87 & 0.135 & 2.16 & 0.072 & 0.134 & 0.998 & 1.75 & 0.257 & 2.35 & 0.147 & 0.257 & 0.999 \\
\hline 1469.8 & 1.85 & 0.153 & 2.18 & 0.088 & 0.162 & 1.063 & 1.71 & 0.286 & 2.40 & 0.173 & 0.295 & 1.034 \\
\hline 1473.0 & 1.84 & 0.158 & 2.19 & 0.087 & 0.160 & 1.008 & 1.72 & 0.282 & 2.39 & 0.165 & 0.284 & 1.005 \\
\hline 1478.8 & 1.75 & 0.200 & 2.19 & 0.109 & 0.191 & 0.955 & 1.64 & 0.309 & 2.38 & 0.183 & 0.300 & 0.971 \\
\hline 1481.8 & 1.95 & 0.106 & 2.18 & 0.055 & 0.107 & 1.008 & 1.82 & 0.232 & 2.37 & 0.128 & 0.233 & 1.004 \\
\hline 1485.1 & 1.75 & 0.186 & 2.15 & 0.105 & 0.184 & 0.990 & 1.63 & 0.308 & 2.35 & 0.188 & 0.307 & 0.994 \\
\hline 1488.5 & 1.55 & 0.282 & 2.16 & 0.161 & 0.249 & 0.884 & 1.44 & 0.392 & 2.37 & 0.250 & 0.360 & 0.917 \\
\hline 1493.1 & 1.65 & 0.233 & 2.15 & 0.138 & 0.227 & 0.973 & 1.53 & 0.348 & 2.35 & 0.223 & 0.342 & 0.982 \\
\hline 1496.5 & 1.62 & 0.242 & 2.14 & 0.146 & 0.236 & 0.977 & 1.51 & 0.355 & 2.34 & 0.232 & 0.349 & 0.984 \\
\hline 1499.6 & 1.54 & 0.276 & 2.13 & 0.164 & 0.253 & 0.915 & 1.43 & 0.388 & 2.34 & 0.255 & 0.365 & 0.940 \\
\hline
\end{tabular}


Table G-1: Laboratory Material Properties and Water Contents Measured on Core Samples from Drill Hole USW SD-9 (Continued)

[Measurements reported by L.E. Fint, U.S. Geological Survey Hydrologic Research Facility; DTN No. GS950308312231.004. J. Curtis and C. Vidano, analysts. Sample number consists of "SD9-" plus depth in feet]

\begin{tabular}{|c|c|c|c|c|c|c|c|c|c|c|c|c|}
\hline \multirow[b]{2}{*}{$\begin{array}{l}\text { Depth } \\
\text { (feet) }\end{array}$} & \multicolumn{6}{|c|}{ Relative Humidity Oven Dried } & \multicolumn{6}{|c|}{$105^{\circ} \mathrm{C}$ Oven-Dried } \\
\hline & $\begin{array}{l}\text { Dry Bulk } \\
\text { Density } \\
\text { (g/cm³) }\end{array}$ & $\begin{array}{l}\text { Porosity } \\
\left(\mathrm{cm}^{3} / \mathrm{cm}^{3}\right)\end{array}$ & $\begin{array}{c}\text { Particle } \\
\text { Density } \\
\left(g / \mathrm{cm}^{3}\right)\end{array}$ & $\begin{array}{c}\text { Grav. } \\
\text { Water } \\
\text { Content } \\
(\mathbf{g} / \mathbf{g})\end{array}$ & $\begin{array}{c}\text { Vol. } \\
\text { Water } \\
\text { Content } \\
\left(\mathrm{cm}^{3} / \mathrm{cm}^{3}\right)\end{array}$ & $\begin{array}{c}\text { Relative } \\
\text { Satn. }\end{array}$ & $\begin{array}{l}\text { Dry Bulk } \\
\text { Density } \\
\left(\mathrm{g}^{\prime} / \mathrm{cm}^{3}\right)\end{array}$ & $\begin{array}{l}\text { Porosity } \\
\left(\mathrm{cm}^{3} / \mathrm{cm}^{3}\right)\end{array}$ & $\begin{array}{l}\text { Particle } \\
\text { Density } \\
\text { (g/cm })\end{array}$ & $\begin{array}{c}\text { Grav. } \\
\text { Water } \\
\text { Content } \\
\text { (g/g) }\end{array}$ & $\begin{array}{c}\text { Vol. } \\
\text { Water } \\
\text { Content } \\
\left(\mathrm{cm}^{3} / \mathrm{cm}^{3}\right)\end{array}$ & $\begin{array}{c}\text { Relative } \\
\text { Satn. }\end{array}$ \\
\hline 1501.2 & 1.58 & 0.271 & 2.16 & 0.157 & 0.248 & 0.913 & 1.47 & 0.378 & 2.36 & 0.241 & 0.354 & 0.937 \\
\hline 1504.9 & 1.70 & 0.218 & 2.17 & 0.124 & 0.210 & 0.965 & 1.58 & 0.329 & 2.36 & 0.203 & 0.321 & 0.977 \\
\hline 1508.2 & 1.67 & 0.237 & 2.19 & 0.137 & 0.229 & 0.963 & 1.56 & 0.341 & 2.37 & 0.212 & 0.332 & 0.974 \\
\hline 1511.4 & 1.63 & 0.255 & 2.19 & 0.150 & 0.246 & 0.963 & 1.53 & 0.358 & 2.38 & 0.228 & 0.349 & 0.974 \\
\hline 1514.1 & 1.77 & 0.168 & 2.13 & 0.095 & 0.168 & 1.000 & 1.65 & 0.281 & 2.30 & 0.170 & 0.281 & 1.000 \\
\hline 1517.7 & 1.65 & 0.244 & 2.18 & 0.147 & 0.242 & 0.990 & 1.54 & 0.351 & 2.38 & 0.226 & 0.349 & 0.993 \\
\hline 1521.7 & 1.63 & 0.249 & 2.18 & 0.147 & 0.240 & 0.961 & 1.53 & 0.356 & 2.37 & 0.227 & 0.346 & 0.973 \\
\hline 1523.5 & 1.63 & 0.250 & 2.17 & 0.154 & 0.250 & 1.000 & 1.52 & 0.355 & 2.36 & 0.233 & 0.355 & 1.000 \\
\hline 1526.4 & 1.63 & 0.249 & 2.17 & 0.145 & 0.236 & 0.949 & 1.53 & 0.352 & 2.35 & 0.222 & 0.339 & 0.964 \\
\hline 1529.7 & 1.64 & 0.240 & 2.16 & 0.139 & 0.227 & 0.946 & 1.53 & 0.349 & 2.35 & 0.219 & 0.336 & 0.963 \\
\hline 1532.1 & 1.57 & 0.283 & 2.19 & 0.157 & 0.246 & 0.871 & 1.47 & 0.383 & 2.38 & 0.236 & 0.347 & 0.905 \\
\hline 1538.6 & 1.70 & 0.217 & 2.17 & 0.124 & 0.210 & 0.970 & 1.60 & 0.322 & 2.35 & 0.198 & 0.315 & 0.979 \\
\hline 1540.9 & 1.72 & 0.211 & 2.18 & 0.123 & 0.211 & 1.000 & 1.62 & 0.312 & 2.35 & 0.192 & 0.312 & 1.000 \\
\hline 1544.1 & 1.61 & 0.261 & 2.18 & 0.153 & 0.246 & 0.943 & 1.51 & 0.361 & 2.36 & 0.229 & 0.346 & 0.959 \\
\hline 1547.4 & 1.76 & 0.195 & 2.18 & 0.108 & 0.190 & 0.977 & 1.65 & 0.302 & 2.36 & 0.181 & 0.298 & 0.985 \\
\hline 1550.5 & 1.60 & 0.268 & 2.19 & 0.157 & 0.251 & 0.937 & 1.50 & 0.370 & 2.38 & 0.236 & 0.353 & 0.955 \\
\hline 1553.8 & 1.62 & 0.266 & 2.20 & 0.156 & 0.251 & 0.947 & 1.51 & 0.368 & 2.39 & 0.234 & 0.354 & 0.961 \\
\hline 1556.7 & 1.67 & 0.238 & 2.19 & 0.131 & 0.218 & 0.916 & 1.57 & 0.337 & 2.37 & 0.202 & 0.317 & 0.940 \\
\hline 1560.1 & 1.70 & 0.227 & 2.20 & 0.127 & 0.215 & 0.946 & 1.60 & 0.325 & 2.37 & 0.196 & 0.313 & 0.962 \\
\hline 1562.2 & 1.70 & 0.226 & 2.19 & 0.128 & 0.218 & 0.962 & 1.60 & 0.327 & 2.37 & 0.199 & 0.318 & 0.974 \\
\hline 1565.6 & 1.70 & 0.215 & 2.17 & 0.124 & 0.211 & 0.981 & 1.60 & 0.317 & 2.34 & 0.195 & 0.313 & 0.987 \\
\hline 1569.1 & 1.70 & 0.221 & 2.18 & 0.126 & 0.213 & 0.963 & 1.59 & 0.325 & 2.36 & 0.199 & 0.316 & 0.975 \\
\hline 1572.3 & 1.78 & 0.189 & 2.19 & 0.104 & 0.185 & 0.982 & 1.68 & 0.289 & 2.36 & 0.170 & 0.285 & 0.988 \\
\hline 1574.8 & 1.69 & 0.235 & 2.21 & 0.128 & 0.217 & 0.923 & 1.59 & 0.335 & 2.40 & 0.199 & 0.317 & 0.946 \\
\hline 1578.0 & 1.68 & 0.236 & 2.20 & 0.131 & 0.220 & 0.932 & 1.58 & 0.333 & 2.37 & 0.201 & 0.317 & 0.952 \\
\hline 1580.7 & 1.69 & 0.229 & 2.19 & 0.128 & 0.216 & 0.943 & 1.59 & 0.328 & 2.36 & 0.199 & 0.315 & 0.961 \\
\hline 1584.0 & 1.55 & 0.292 & 2.19 & 0.171 & 0.265 & 0.909 & 1.45 & 0.390 & 2.38 & 0.250 & 0.363 & 0.932 \\
\hline 1586.6 & 1.78 & 0.188 & 2.19 & 0.106 & 0.188 & 0.997 & 1.65 & 0.309 & 2.40 & 0.187 & 0.309 & 0.998 \\
\hline 1590.0 & 1.60 & 0.261 & 2.17 & 0.163 & 0.262 & 1.001 & 1.50 & 0.360 & 2.35 & 0.239 & 0.360 & 1.000 \\
\hline 1592.8 & 1.63 & 0.255 & 2.18 & 0.143 & 0.232 & 0.911 & 1.52 & 0.356 & 2.37 & 0.219 & 0.333 & 0.936 \\
\hline 1595.8 & 1.60 & 0.272 & 2.19 & 0.143 & 0.228 & 0.838 & 1.50 & 0.367 & 2.37 & 0.216 & 0.323 & 0.880 \\
\hline
\end{tabular}


Table G-1: Laboratory Material Properties and Water Contents Measured on Core Samples from Drill Hole USW SD-9 (Continued)

[Measurements reported by L.E. Flint, U.S. Geological Survey Hydrologic Research Facility; DTN No. GS950308312231.004. J. Curtis and C. Vidano, analysts. Sample number consists of "SD9-" plus depth in feet]

\begin{tabular}{|c|c|c|c|c|c|c|c|c|c|c|c|c|}
\hline \multirow[b]{2}{*}{$\begin{array}{l}\text { Depth } \\
\text { (feet) }\end{array}$} & \multicolumn{6}{|c|}{ Relative Humidity Oven Dried } & \multicolumn{6}{|c|}{$105^{\circ} \mathrm{C}$ Oven-Dried } \\
\hline & $\begin{array}{l}\text { Dry Bulk } \\
\text { Density } \\
\text { (g/cm })\end{array}$ & $\begin{array}{l}\text { Porosity } \\
\left(\mathrm{cm}^{3} / \mathrm{cm}^{3}\right)\end{array}$ & $\begin{array}{l}\text { Particle } \\
\text { Density } \\
\text { (g/cm })\end{array}$ & $\begin{array}{c}\text { Grav. } \\
\text { Water } \\
\text { Content } \\
(\mathbf{g} / \mathbf{g})\end{array}$ & $\begin{array}{c}\text { Vol. } \\
\text { Water } \\
\text { Content } \\
\left(\mathrm{cm}^{3} / \mathrm{cm}^{3}\right)\end{array}$ & $\begin{array}{c}\text { Relative } \\
\text { Satn. }\end{array}$ & $\begin{array}{l}\text { Dry Bulk } \\
\text { Density } \\
\left(\mathrm{g} / \mathrm{cm}^{3}\right)\end{array}$ & $\begin{array}{l}\text { Porosity } \\
\left(\mathrm{cm}^{3} / \mathrm{cm}^{3}\right)\end{array}$ & $\begin{array}{l}\text { Particle } \\
\text { Density } \\
\left(\mathrm{g} / \mathrm{cm}^{3}\right)\end{array}$ & $\begin{array}{l}\text { Grav. } \\
\text { Water } \\
\text { Content } \\
(\mathbf{g} / \mathbf{g})\end{array}$ & $\begin{array}{c}\text { Vol. } \\
\text { Water } \\
\text { Content } \\
\left(\mathrm{cm}^{3} / \mathrm{cm}^{3}\right)\end{array}$ & $\begin{array}{c}\text { Relative } \\
\text { Satn. }\end{array}$ \\
\hline 1598.3 & 1.95 & 0.110 & 2.19 & 0.061 & 0.119 & 1.082 & 1.84 & 0.220 & 2.36 & 0.124 & 0.229 & 1.041 \\
\hline 1601.9 & 1.55 & 0.285 & 2.17 & 0.141 & 0.219 & 0.767 & 1.46 & 0.382 & 2.36 & 0.216 & 0.315 & 0.826 \\
\hline 1602.8 & 1.70 & 0.208 & 2.15 & 0.092 & 0.157 & 0.754 & 1.60 & 0.312 & 2.32 & 0.163 & 0.260 & 0.835 \\
\hline 1605.7 & 1.66 & 0.231 & 2.16 & 0.108 & 0.178 & 0.771 & 1.56 & 0.328 & 2.33 & 0.176 & 0.275 & 0.838 \\
\hline 1610.4 & 1.57 & 0.282 & 2.19 & 0.145 & 0.228 & 0.807 & 1.47 & 0.379 & 2.37 & 0.220 & 0.324 & 0.856 \\
\hline 1612.6 & 1.64 & 0.241 & 2.16 & 0.143 & 0.235 & 0.974 & 1.55 & 0.336 & 2.33 & 0.213 & 0.330 & 0.982 \\
\hline 1615.2 & 1.48 & 0.315 & 2.17 & 0.177 & 0.263 & 0.836 & 1.39 & 0.406 & 2.34 & 0.255 & 0.354 & 0.873 \\
\hline 1617.5 & 1.57 & 0.279 & 2.18 & 0.170 & 0.268 & 0.961 & 1.48 & 0.372 & 2.36 & 0.244 & 0.361 & 0.971 \\
\hline 1621.2 & 1.62 & 0.247 & 2.15 & 0.119 & 0.192 & 0.777 & 1.52 & 0.345 & 2.32 & 0.191 & 0.290 & 0.840 \\
\hline 1623.8 & 1.66 & 0.235 & 2.17 & 0.135 & 0.224 & 0.955 & 1.57 & 0.331 & 2.34 & 0.205 & 0.320 & 0.968 \\
\hline 1627.1 & 1.60 & 0.262 & 2.17 & 0.141 & 0.226 & 0.863 & 1.50 & 0.358 & 2.35 & 0.214 & 0.323 & 0.900 \\
\hline 1632.0 & 1.61 & 0.255 & 2.16 & 0.154 & 0.248 & 0.971 & 1.52 & 0.352 & 2.34 & 0.227 & 0.344 & 0.979 \\
\hline 1635.1 & 1.62 & 0.253 & 2.17 & 0.126 & 0.204 & 0.805 & 1.52 & 0.356 & 2.35 & 0.203 & 0.307 & 0.861 \\
\hline 1638.1 & 1.58 & 0.271 & 2.16 & 0.166 & 0.262 & 0.966 & 1.48 & 0.365 & 2.34 & 0.240 & 0.356 & 0.975 \\
\hline 1641.2 & 1.58 & 0.266 & 2.16 & 0.167 & 0.264 & 0.992 & 1.49 & 0.362 & 2.33 & 0.242 & 0.360 & 0.994 \\
\hline 1643.7 & 1.64 & 0.238 & 2.15 & 0.144 & 0.236 & 0.994 & 1.54 & 0.336 & 2.32 & 0.217 & 0.335 & 0.996 \\
\hline 1646.5 & 1.61 & 0.256 & 2.17 & 0.152 & 0.245 & 0.954 & 1.51 & 0.354 & 2.34 & 0.226 & 0.342 & 0.966 \\
\hline 1649.4 & 1.61 & 0.258 & 2.17 & 0.152 & 0.245 & 0.949 & 1.51 & 0.356 & 2.35 & 0.226 & 0.343 & 0.963 \\
\hline 1652.7 & 1.57 & 0.275 & 2.17 & 0.174 & 0.273 & 0.996 & 1.48 & 0.368 & 2.34 & 0.249 & 0.367 & 0.997 \\
\hline 1655.7 & 1.60 & 0.262 & 2.16 & 0.161 & 0.257 & 0.982 & 1.50 & 0.357 & 2.34 & 0.235 & 0.353 & 0.987 \\
\hline 1658.7 & 1.64 & 0.241 & 2.16 & 0.144 & 0.235 & 0.979 & 1.54 & 0.338 & 2.33 & 0.216 & 0.333 & 0.985 \\
\hline 1661.7 & 1.59 & 0.262 & 2.16 & 0.164 & 0.261 & 0.996 & 1.50 & 0.353 & 2.32 & 0.234 & 0.351 & 0.997 \\
\hline 1664.8 & 1.64 & 0.239 & 2.16 & 0.144 & 0.236 & 0.985 & 1.55 & 0.332 & 2.32 & 0.212 & 0.328 & 0.989 \\
\hline 1667.6 & 1.62 & 0.252 & 2.17 & 0.155 & 0.251 & 0.994 & 1.53 & 0.345 & 2.33 & 0.225 & 0.344 & 0.996 \\
\hline 1670.4 & 1.64 & 0.238 & 2.15 & 0.142 & 0.233 & 0.980 & 1.55 & 0.333 & 2.32 & 0.212 & 0.328 & 0.986 \\
\hline 1671.6 & 1.63 & 0.246 & 2.17 & 0.145 & 0.238 & 0.967 & 1.54 & 0.338 & 2.33 & 0.214 & 0.330 & 0.976 \\
\hline 1674.5 & 1.65 & 0.235 & 2.16 & 0.139 & 0.230 & 0.980 & 1.56 & 0.328 & 2.32 & 0.207 & 0.323 & 0.985 \\
\hline 1677.4 & 1.63 & 0.245 & 2.16 & 0.148 & 0.242 & 0.989 & 1.54 & 0.338 & 2.32 & 0.218 & 0.336 & 0.992 \\
\hline 1680.3 & 1.61 & 0.257 & 2.17 & 0.144 & 0.233 & 0.906 & 1.51 & 0.357 & 2.35 & 0.220 & 0.333 & 0.933 \\
\hline 1683.6 & 1.57 & 0.277 & 2.17 & 0.171 & 0.268 & 0.968 & 1.47 & 0.372 & 2.34 & 0.247 & 0.363 & 0.976 \\
\hline 1686.2 & 1.70 & 0.209 & 2.15 & 0.118 & 0.201 & 0.962 & 1.61 & 0.305 & 2.31 & 0.185 & 0.297 & 0.974 \\
\hline
\end{tabular}


Table G-1: Laboratory Material Properties and Water Contents Measured on Core Samples from Drill Hole USW SD-9 (Continued)

[Measurements reported by L.E. Fint, U.S. Geological Survey Hydrologic Research Facility; DTN No. GS950308312231.004. J. Curtis and C. Vidano, analysts. Sample number consists of "SD9-" plus depth in feet]

\begin{tabular}{|c|c|c|c|c|c|c|c|c|c|c|c|c|}
\hline \multirow[b]{2}{*}{$\begin{array}{l}\text { Depth } \\
\text { (feet) }\end{array}$} & \multicolumn{6}{|c|}{ Relative Humidity Oven Dried } & \multicolumn{6}{|c|}{$105^{\circ} \mathrm{C}$ Oven-Dried } \\
\hline & $\begin{array}{l}\text { Dry Bulk } \\
\text { Density } \\
\left(\mathrm{g} / \mathrm{cm}^{3}\right)\end{array}$ & 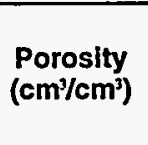 & $\begin{array}{l}\text { Particle } \\
\text { Density } \\
\text { (g/cm) }\end{array}$ & $\begin{array}{c}\text { Grav. } \\
\text { Water } \\
\text { Content } \\
(g / g)\end{array}$ & $\begin{array}{c}\text { Vol. } \\
\text { Water } \\
\text { Content } \\
\left(\mathrm{cm}^{3} / \mathrm{cm}^{3}\right)\end{array}$ & $\begin{array}{c}\text { Relative } \\
\text { Satn. }\end{array}$ & $\begin{array}{l}\text { Dry Bulk } \\
\text { Density } \\
\text { (g/cm³) }\end{array}$ & $\begin{array}{l}\text { Porosity } \\
\left(\mathrm{cm}^{3} / \mathrm{cm}^{3}\right)\end{array}$ & $\begin{array}{l}\text { Particle } \\
\text { Density } \\
\text { (g/cm³) }\end{array}$ & $\begin{array}{c}\text { Grav. } \\
\text { Water } \\
\text { Content } \\
\text { (g/g) }\end{array}$ & $\begin{array}{c}\text { Vol. } \\
\text { Water } \\
\text { Content } \\
\left(\mathrm{cm}^{3} / \mathrm{cm}^{3}\right)\end{array}$ & $\begin{array}{c}\text { Relative } \\
\text { Satn. }\end{array}$ \\
\hline 1689.1 & 1.55 & 0.286 & 2.17 & 0.180 & 0.279 & 0.977 & 1.46 & 0.379 & 2.35 & 0.255 & 0.372 & 0.982 \\
\hline 1692.6 & 1.62 & 0.254 & 2.17 & 0.153 & 0.248 & 0.976 & 1.52 & 0.349 & 2.34 & 0.225 & 0.343 & 0.982 \\
\hline 1695.6 & 1.58 & 0.270 & 2.17 & 0.164 & 0.259 & 0.959 & 1.48 & 0.370 & 2.35 & 0.242 & 0.358 & 0.970 \\
\hline 1699.0 & 1.59 & 0.269 & 2.17 & 0.165 & 0.262 & 0.972 & 1.49 & 0.367 & 2.35 & 0.242 & 0.360 & 0.979 \\
\hline 1702.0 & 1.63 & 0.246 & 2.16 & 0.148 & 0.240 & 0.976 & 1.54 & 0.341 & 2.33 & 0.218 & 0.335 & 0.983 \\
\hline 1704.7 & 1.61 & 0.256 & 2.17 & 0.152 & 0.246 & 0.961 & 1.52 & 0.351 & 2.34 & 0.225 & 0.341 & 0.972 \\
\hline 1707.8 & 1.62 & 0.254 & 2.17 & 0.154 & 0.249 & 0.980 & 1.52 & 0.351 & 2.34 & 0.227 & 0.346 & 0.986 \\
\hline 1710.8 & 1.63 & 0.249 & 2.16 & 0.150 & 0.244 & 0.982 & 1.53 & 0.344 & 2.33 & 0.222 & 0.340 & 0.987 \\
\hline 1713.7 & 1.64 & 0.244 & 2.17 & 0.146 & 0.239 & 0.980 & 1.54 & 0.340 & 2.34 & 0.217 & 0.335 & 0.986 \\
\hline 1717.1 & 1.65 & 0.239 & 2.17 & 0.142 & 0.234 & 0.979 & 1.55 & 0.339 & 2.35 & 0.215 & 0.334 & 0.985 \\
\hline 1719.7 & 1.70 & 0.215 & 2.16 & 0.124 & 0.211 & 0.981 & 1.60 & 0.312 & 2.33 & 0.193 & 0.308 & 0.987 \\
\hline 1723.1 & 1.68 & 0.232 & 2.18 & 0.137 & 0.229 & 0.990 & 1.57 & 0.337 & 2.37 & 0.213 & 0.334 & 0.993 \\
\hline 1725.9 & 1.69 & 0.223 & 2.18 & 0.132 & 0.224 & 1.005 & 1.60 & 0.319 & 2.35 & 0.200 & 0.320 & 1.003 \\
\hline 1729.1 & 1.66 & 0.241 & 2.19 & 0.144 & 0.239 & 0.988 & 1.56 & 0.341 & 2.37 & 0.216 & 0.338 & 0.991 \\
\hline 1731.4 & 1.66 & 0.239 & 2.18 & 0.141 & 0.234 & 0.976 & 1.56 & 0.340 & 2.36 & 0.214 & 0.334 & 0.983 \\
\hline 1734.7 & 1.84 & 0.164 & 2.20 & 0.088 & 0.161 & 0.981 & 1.74 & 0.261 & 2.36 & 0.148 & 0.258 & 0.988 \\
\hline 1737.7 & 1.69 & 0.223 & 2.18 & 0.130 & 0.220 & 0.987 & 1.60 & 0.315 & 2.34 & 0.195 & 0.312 & 0.991 \\
\hline 1743.9 & 1.59 & 0.266 & 2.16 & 0.170 & 0.270 & 1.017 & 1.50 & 0.351 & 2.31 & 0.236 & 0.355 & 1.013 \\
\hline 1746.8 & 1.61 & 0.282 & 2.24 & 0.170 & 0.274 & 0.971 & 1.52 & 0.371 & 2.42 & 0.239 & 0.363 & 0.978 \\
\hline 1749.8 & 1.66 & 0.254 & 2.22 & 0.147 & 0.243 & 0.957 & 1.57 & 0.342 & 2.38 & 0.211 & 0.331 & 0.968 \\
\hline 1753.0 & 1.61 & 0.277 & 2.23 & 0.167 & 0.270 & 0.975 & 1.53 & 0.359 & 2.39 & 0.230 & 0.353 & 0.981 \\
\hline 1756.0 & 1.67 & 0.254 & 2.24 & 0.140 & 0.234 & 0.921 & 1.58 & 0.340 & 2.40 & 0.202 & 0.319 & 0.941 \\
\hline 1762.2 & 1.65 & 0.257 & 2.23 & 0.152 & 0.251 & 0.979 & 1.57 & 0.341 & 2.38 & 0.214 & 0.336 & 0.984 \\
\hline 1765.3 & 1.92 & 0.150 & 2.26 & 0.080 & 0.153 & 1.017 & 1.83 & 0.239 & 2.40 & 0.132 & 0.241 & 1.011 \\
\hline 1767.8 & 1.79 & 0.202 & 2.24 & 0.113 & 0.202 & 1.003 & 1.71 & 0.287 & 2.39 & 0.168 & 0.287 & 1.002 \\
\hline 1770.5 & 1.79 & 0.192 & 2.22 & 0.112 & 0.200 & 1.044 & 1.69 & 0.296 & 2.40 & 0.180 & 0.304 & 1.028 \\
\hline 1774.5 & 1.84 & 0.162 & 2.19 & 0.086 & 0.157 & 0.972 & 1.75 & 0.251 & 2.33 & 0.141 & 0.246 & 0.982 \\
\hline 1776.8 & 1.85 & 0.150 & 2.18 & 0.082 & 0.153 & 1.014 & 1.76 & 0.245 & 2.33 & 0.141 & 0.248 & 1.009 \\
\hline 1779.9 & 1.82 & 0.205 & 2.29 & 0.112 & 0.203 & 0.989 & 1.75 & 0.275 & 2.41 & 0.156 & 0.273 & 0.992 \\
\hline 1782.8 & 1.88 & 0.152 & 2.22 & 0.080 & 0.150 & 0.984 & 1.78 & 0.255 & 2.39 & 0.142 & 0.253 & 0.990 \\
\hline 1786.4 & 1.72 & 0.243 & 2.28 & 0.139 & 0.240 & 0.985 & 1.65 & 0.312 & 2.40 & 0.186 & 0.308 & 0.989 \\
\hline
\end{tabular}


Table G-1: Laboratory Material Properties and Water Contents Measured on Core Samples from Drill Hole USW SD-9 (Continued)

[Measurements reported by L.E. Flint, U.S. Geological Survey Hydrologic Research Facility; DTN No. GS950308312231.004. J. Curtis and C. Vidano, analysts. Sample number consists of "SD9-" plus depth in feet]

\begin{tabular}{|c|c|c|c|c|c|c|c|c|c|c|c|c|}
\hline \multirow[b]{2}{*}{$\begin{array}{l}\text { Depth } \\
\text { (feet) }\end{array}$} & \multicolumn{6}{|c|}{ Relative Humidity Oven Drled } & \multicolumn{6}{|c|}{$105^{\circ} \mathrm{C}$ Oven-Dried } \\
\hline & $\begin{array}{l}\text { Dry Bulk } \\
\text { Density } \\
\text { (g/cm³) }\end{array}$ & $\begin{array}{l}\text { Porosity } \\
\left(\mathrm{cm}^{3} / \mathrm{cm}^{3}\right)\end{array}$ & $\begin{array}{c}\text { Particle } \\
\text { Density } \\
\left(\mathrm{g} / \mathrm{cm}^{3}\right)\end{array}$ & $\begin{array}{c}\text { Grav. } \\
\text { Water } \\
\text { Content } \\
\text { (g/g) }\end{array}$ & $\begin{array}{c}\text { Vol. } \\
\text { Water } \\
\text { Content } \\
\left(\mathrm{cm}^{3} / \mathrm{cm}^{3}\right)\end{array}$ & $\begin{array}{c}\text { Relative } \\
\text { Satn. }\end{array}$ & $\begin{array}{l}\text { Dry Bulk } \\
\text { Density } \\
\text { (g/cm })\end{array}$ & $\begin{array}{l}\text { Porosity } \\
\left(\mathrm{cm}^{3} / \mathrm{cm}^{3}\right)\end{array}$ & $\begin{array}{l}\text { Particle } \\
\text { Density } \\
\left(\mathrm{g} / \mathrm{cm}^{3}\right)\end{array}$ & $\begin{array}{c}\text { Grav. } \\
\text { Water } \\
\text { Content } \\
(\mathbf{g} / \mathbf{g})\end{array}$ & $\begin{array}{c}\text { Vol. } \\
\text { Water } \\
\text { Content } \\
\left(\mathrm{cm}^{3} / \mathrm{cm}^{3}\right)\end{array}$ & $\begin{array}{c}\text { Relative } \\
\text { Satn. }\end{array}$ \\
\hline 1788.8 & 1.90 & 0.177 & 2.31 & 0.094 & 0.179 & 1.011 & 1.83 & 0.252 & 2.44 & 0.139 & 0.254 & 1.008 \\
\hline 1791.6 & 1.88 & 0.176 & 2.29 & 0.092 & 0.173 & 0.986 & 1.81 & 0.252 & 2.42 & 0.138 & 0.249 & 0.990 \\
\hline 1795,4 & 1.81 & 0.201 & 2.27 & 0.114 & 0.207 & 1.031 & 1.72 & 0.288 & 2.42 & 0.171 & 0.294 & 1.021 \\
\hline 1798.1 & 1.87 & 0.192 & 2.32 & 0.100 & 0.188 & 0.979 & 1.81 & 0.254 & 2.43 & 0.138 & 0.250 & 0.984 \\
\hline 1803.9 & 2.01 & 0.166 & 2.42 & 0.082 & 0.165 & 0.989 & 1.95 & 0.229 & 2.53 & 0.116 & 0.227 & 0.992 \\
\hline 1806.8 & 2.09 & 0.171 & 2.52 & 0.080 & 0.167 & 0.977 & 2.04 & 0.220 & 2.62 & 0.106 & 0.216 & 0.982 \\
\hline 1811.0 & 2.05 & 0.196 & 2.55 & 0.094 & 0.193 & 0.985 & 2.00 & 0.239 & 2.63 & 0.118 & 0.237 & 0.988 \\
\hline 1813.2 & 2.01 & 0.194 & 2.50 & 0.096 & 0.194 & 1.000 & 1.96 & 0.248 & 2.61 & 0.127 & 0.248 & 1.000 \\
\hline 1816.6 & 2.08 & 0.159 & 2.47 & 0.078 & 0.161 & 1.015 & 2.01 & 0.227 & 2.60 & 0.114 & 0.229 & 1.010 \\
\hline 1822.6 & 1.77 & 0.204 & 2.23 & 0.107 & 0.189 & 0.928 & 1.68 & 0.293 & 2.38 & 0.165 & 0.279 & 0.950 \\
\hline 1825.0 & 1.68 & 0.258 & 2.27 & 0.154 & 0.258 & 1.000 & 1.61 & 0.334 & 2.41 & 0.208 & 0.333 & 1.000 \\
\hline 1827.8 & 1.72 & 0.233 & 2.24 & 0.135 & 0.233 & 0.999 & 1.64 & 0.312 & 2.39 & 0.190 & 0.312 & 0.999 \\
\hline 1831.0 & 1.75 & 0.220 & 2.24 & 0.122 & 0.213 & 0.965 & 1.67 & 0.298 & 2.38 & 0.174 & 0.290 & 0.974 \\
\hline 1834.0 & 1.81 & 0.191 & 2.23 & 0.100 & 0.181 & 0.949 & 1.73 & 0.273 & 2.37 & 0.153 & 0.263 & 0.964 \\
\hline 1837.0 & 1.78 & 0.208 & 2.25 & 0.112 & 0.199 & 0.956 & 1.70 & 0.284 & 2.38 & 0.161 & 0.275 & 0.968 \\
\hline 1839.7 & 1.74 & 0.229 & 2.26 & 0.128 & 0.222 & 0.969 & 1.66 & 0.313 & 2.41 & 0.184 & 0.305 & 0.977 \\
\hline 1842.8 & 1.74 & 0.237 & 2.28 & 0.133 & 0.232 & 0.977 & 1.66 & 0.316 & 2.43 & 0.187 & 0.310 & 0.983 \\
\hline 1845.9 & 1.76 & 0.224 & 2.27 & 0.119 & 0.210 & 0.938 & 1.68 & 0.302 & 2.41 & 0.172 & 0.289 & 0.954 \\
\hline 1848.9 & 1.70 & 0.252 & 2.27 & 0.141 & 0.239 & 0.949 & 1.62 & 0.326 & 2.41 & 0.193 & 0.313 & 0.961 \\
\hline 1851.7 & 1.18 & 0.474 & 2.24 & 0.236 & 0.277 & 0.585 & 1.11 & 0.538 & 2.41 & 0.306 & 0.341 & 0.634 \\
\hline 1854.8 & 1.63 & 0.279 & 2.27 & 0.165 & 0.270 & 0.966 & 1.56 & 0.356 & 2.42 & 0.222 & 0.346 & 0.973 \\
\hline 1857.7 & 1.58 & 0.308 & 2.28 & 0.184 & 0.291 & 0.946 & 1.51 & 0.381 & 2.44 & 0.241 & 0.364 & 0.956 \\
\hline 1860.5 & 1.77 & 0.215 & 2.25 & 0.117 & 0.208 & 0.967 & 1.69 & 0.292 & 2.39 & 0.168 & 0.285 & 0.976 \\
\hline 1863.7 & 1.83 & 0.169 & 2.20 & 0.086 & 0.158 & 0.936 & 1.75 & 0.254 & 2.34 & 0.139 & 0.243 & 0.957 \\
\hline 1866.9 & 1.67 & 0.264 & 2.27 & 0.155 & 0.258 & 0.978 & 1.58 & 0.346 & 2.42 & 0.215 & 0.341 & 0.983 \\
\hline 1869.7 & 1.51 & 0.390 & 2.48 & 0.249 & 0.376 & 0.966 & 1.51 & 0.395 & 2.49 & 0.253 & 0.381 & 0.967 \\
\hline 1872.6 & 1.59 & 0.354 & 2.47 & 0.191 & 0.304 & 0.858 & 1.59 & 0.357 & 2.47 & 0.193 & 0.307 & 0.859 \\
\hline 1875.8 & 1.70 & 0.332 & 2.55 & 0.179 & 0.306 & 0.921 & 1.70 & 0.337 & 2.56 & 0.183 & 0.310 & 0.922 \\
\hline 1878.6 & 1.65 & 0.352 & 2.55 & 0.198 & 0.326 & 0.926 & 1.65 & 0.358 & 2.56 & 0.202 & 0.332 & 0.927 \\
\hline 1884.9 & 1.67 & 0.354 & 2.59 & 0.201 & 0.337 & 0.952 & 1.67 & 0.360 & 2.61 & 0.206 & 0.343 & 0.953 \\
\hline 1887.8 & 1.68 & 0.347 & 2.58 & 0.196 & 0.329 & 0.947 & 1.67 & 0.355 & 2.59 & 0.201 & 0.337 & 0.948 \\
\hline
\end{tabular}


Table G-1: Laboratory Material Properties and Water Contents Measured on Core Samples from Drill Hole USW SD-9 (Continued)

[Measurements reported by L.E. Flint, U.S. Geological Survey Hydrologic Research Facility; DTN No. GS950308312231.004. J. Curtis and C. Vidano, analysts. Sample number consists of "SD9-" plus depth in feet]

\begin{tabular}{|c|c|c|c|c|c|c|c|c|c|c|c|c|}
\hline \multirow[b]{2}{*}{$\begin{array}{l}\text { Depth } \\
\text { (feet) }\end{array}$} & \multicolumn{6}{|c|}{ Relative Humidity Oven Dried } & \multicolumn{6}{|c|}{$105^{\circ} \mathrm{C}$ Oven-Dried } \\
\hline & $\begin{array}{c}\text { Dry Bulk } \\
\text { Density } \\
\left(\mathrm{g} / \mathrm{cm}^{3}\right)\end{array}$ & $\begin{array}{l}\text { Porosity } \\
\left(\mathrm{cm}^{3} / \mathrm{cm}^{3}\right)\end{array}$ & $\begin{array}{c}\text { Particle } \\
\text { Density } \\
\left(\mathrm{g} / \mathrm{cm}^{3}\right)\end{array}$ & $\begin{array}{c}\text { Grav. } \\
\text { Water } \\
\text { Content } \\
\text { (g/g) }\end{array}$ & $\begin{array}{c}\text { Vol. } \\
\text { Water } \\
\text { Content } \\
\left(\mathrm{cm}^{3} / \mathrm{cm}^{3}\right)\end{array}$ & $\begin{array}{c}\text { Relative } \\
\text { Satn. }\end{array}$ & $\begin{array}{l}\text { Dry Bulk } \\
\text { Density } \\
\left(\mathrm{g} / \mathrm{cm}^{3}\right)\end{array}$ & $\begin{array}{l}\text { Porosity } \\
\left(\mathrm{cm}^{3} / \mathrm{cm}^{3}\right)\end{array}$ & $\begin{array}{l}\text { Particle } \\
\text { Density } \\
\left(\mathrm{g} / \mathrm{cm}^{3}\right)\end{array}$ & $\begin{array}{c}\text { Grav. } \\
\text { Water } \\
\text { Content } \\
(\mathrm{g} / \mathrm{g})\end{array}$ & $\begin{array}{c}\text { Vol. } \\
\text { Water } \\
\text { Content } \\
\left(\mathrm{cm}^{3} / \mathbf{c m}^{3}\right)\end{array}$ & $\begin{array}{c}\text { Relative } \\
\text { Satn. }\end{array}$ \\
\hline 1890.6 & 1.71 & 0.340 & 2.59 & 0.192 & 0.328 & 0.963 & 1.70 & 0.350 & 2.61 & 0.199 & 0.337 & 0.964 \\
\hline 1892.8 & 1.72 & 0.338 & 2.59 & 0.188 & 0.323 & 0.956 & 1.71 & 0.346 & 2.61 & 0.194 & 0.331 & 0.957 \\
\hline 1895.9 & 1.72 & 0.333 & 2.59 & 0.169 & 0.291 & 0.872 & 1.71 & 0.343 & 2.61 & 0.175 & 0.301 & 0.876 \\
\hline 1900.0 & 1.77 & 0.315 & 2.59 & 0.155 & 0.274 & 0.869 & 1.76 & 0.327 & 2.62 & 0.162 & 0.285 & 0.874 \\
\hline 1903.0 & 1.80 & 0.302 & 2.58 & 0.159 & 0.286 & 0.947 & 1.79 & 0.315 & 2.61 & 0.167 & 0.299 & 0.950 \\
\hline 1905.8 & 1.79 & 0.303 & 2.57 & 0.156 & 0.280 & 0.924 & 1.78 & 0.315 & 2.60 & 0.164 & 0.292 & 0.927 \\
\hline 1909.4 & 1.79 & 0.309 & 2.58 & 0.165 & 0.295 & 0.956 & 1.78 & 0.320 & 2.61 & 0.173 & 0.306 & 0.958 \\
\hline 1912 & 1.80 & 0.305 & 2.59 & 0.164 & 0.296 & 0.969 & 1.79 & 0.316 & 2.62 & 0.172 & 0.307 & 0.970 \\
\hline 1917.7 & 1.80 & 0.304 & 2.59 & 0.166 & 0.299 & 0.986 & 1.79 & 0.315 & 2.62 & 0.174 & 0.311 & 0.986 \\
\hline 1920.7 & 1.80 & 0.303 & 2.58 & 0.166 & 0.300 & 0.990 & 1.79 & 0.314 & 2.61 & 0.174 & 0.311 & 0.991 \\
\hline 1924.0 & 1.82 & 0.295 & 2.58 & 0.158 & 0.287 & 0.973 & 1.81 & 0.305 & 2.60 & 0.164 & 0.297 & 0.974 \\
\hline 1926.8 & 1.83 & 0.291 & 2.58 & 0.157 & 0.286 & 0.985 & 1.82 & 0.301 & 2.60 & 0.163 & 0.297 & 0.986 \\
\hline 1929.9 & 1.82 & 0.296 & 2.58 & 0.158 & 0.287 & 0.971 & 1.81 & 0.305 & 2.60 & 0.164 & 0.297 & 0.972 \\
\hline 1932.9 & 1.84 & 0.289 & 2.58 & 0.156 & 0.287 & 0.993 & 1.83 & 0.297 & 2.60 & 0.161 & 0.295 & 0.993 \\
\hline 1936.0 & 1.83 & 0.293 & 2.58 & 0.158 & 0.289 & 0.987 & 1.82 & 0.303 & 2.60 & 0.165 & 0.299 & 0.987 \\
\hline 1939.5 & 1.87 & 0.274 & 2.57 & 0.148 & 0.277 & 1.008 & 1.85 & 0.288 & 2.60 & 0.157 & 0.290 & 1.008 \\
\hline 1943.1 & 1.89 & 0.266 & 2.58 & 0.150 & 0.283 & 1.065 & 1.88 & 0.281 & 2.61 & 0.159 & 0.298 & 1.062 \\
\hline 1945.5 & 1.89 & 0.263 & 2.57 & 0.137 & 0.259 & 0.985 & 1.88 & 0.279 & 2.60 & 0.146 & 0.275 & 0.985 \\
\hline 1948.0 & 1.90 & 0.261 & 2.57 & 0.135 & 0.255 & 0.979 & 1.88 & 0.276 & 2.60 & 0.144 & 0.270 & 0.980 \\
\hline 1951.4 & 1.88 & 0.269 & 2.57 & 0.140 & 0.262 & 0.974 & 1.86 & 0.284 & 2.60 & 0.149 & 0.277 & 0.975 \\
\hline 1953.6 & 1.88 & 0.269 & 2.57 & 0.145 & 0.273 & 1.014 & 1.86 & 0.284 & 2.61 & 0.155 & 0.288 & 1.013 \\
\hline 1957.1 & 1.93 & 0.247 & 2.56 & 0.126 & 0.243 & 0.984 & 1.91 & 0.263 & 2.60 & 0.135 & 0.259 & 0.985 \\
\hline 1960.7 & 1.94 & 0.242 & 2.56 & 0.123 & 0.240 & 0.990 & 1.92 & 0.258 & 2.59 & 0.133 & 0.256 & 0.991 \\
\hline 1963.2 & 1.96 & 0.233 & 2.56 & 0.116 & 0.228 & 0.981 & 1.95 & 0.250 & 2.59 & 0.126 & 0.245 & 0.982 \\
\hline 1966.1 & 1.96 & 0.235 & 2.56 & 0.119 & 0.233 & 0.992 & 1.94 & 0.252 & 2.59 & 0.129 & 0.250 & 0.992 \\
\hline 1968.6 & 1.97 & 0.228 & 2.55 & 0.114 & 0.225 & 0.987 & 1.95 & 0.245 & 2.59 & 0.124 & 0.242 & 0.988 \\
\hline 1971.6 & 1.99 & 0.213 & 2.53 & 0.106 & 0.210 & 0.986 & 1.97 & 0.232 & 2.57 & 0.116 & 0.229 & 0.987 \\
\hline 1975.0 & 1.99 & 0.206 & 2.51 & 0.102 & 0.202 & 0.982 & 1.96 & 0.234 & 2.57 & 0.117 & 0.230 & 0.984 \\
\hline 1977.6 & 1.96 & 0.218 & 2.50 & 0.117 & 0.229 & 1.052 & 1.93 & 0.239 & 2.54 & 0.129 & 0.250 & 1.048 \\
\hline 1981.0 & 1.88 & 0.249 & 2.50 & 0.132 & 0.249 & 0.998 & 1.86 & 0.270 & 2.54 & 0.145 & 0.270 & 0.998 \\
\hline 1983.8 & 1.81 & 0.273 & 2.50 & 0.149 & 0.271 & 0.991 & 1.79 & 0.294 & 2.54 & 0.163 & 0.292 & 0.992 \\
\hline
\end{tabular}


Table G-1: Laboratory Material Properties and Water Contents Measured on Core Samples from Drill Hole USW SD-9 (Continued)

[Measurements reported by L.E. Flint, U.S. Geological Survey Hydrologic Research Facility; DTN No. GS950308312231.004. J. Curtis and C. Vidano, analysts. Sample number consists of "SD9-" plus depth in feet]

\begin{tabular}{|c|c|c|c|c|c|c|c|c|c|c|c|c|}
\hline \multirow[b]{2}{*}{$\begin{array}{l}\text { Depth } \\
\text { (feet) }\end{array}$} & \multicolumn{6}{|c|}{ Relative Humidity Oven Dried } & \multicolumn{6}{|c|}{$105^{\circ} \mathrm{C}$ Oven-Dried } \\
\hline & $\begin{array}{l}\text { Dry Bulk } \\
\text { Density } \\
\left(\mathrm{g}^{\prime} / \mathrm{cm}^{3}\right)\end{array}$ & $\begin{array}{l}\text { Porosity } \\
\left(\mathrm{cm}^{3} / \mathrm{cm}^{3}\right)\end{array}$ & $\begin{array}{l}\text { Particle } \\
\text { Density } \\
\left(\mathrm{g}^{\prime} / \mathrm{cm}^{3}\right)\end{array}$ & $\begin{array}{c}\text { Grav. } \\
\text { Water } \\
\text { Content } \\
(g / g)\end{array}$ & $\begin{array}{c}\text { Vol. } \\
\text { Water } \\
\text { Content } \\
\left(\mathrm{cm}^{3} / \mathrm{cm}^{3}\right)\end{array}$ & $\begin{array}{c}\text { Relative } \\
\text { Satn. }\end{array}$ & $\begin{array}{l}\text { Dry Bulk } \\
\text { Density } \\
\left(\mathrm{g} / \mathrm{cm}^{3}\right)\end{array}$ & $\begin{array}{l}\text { Porosity } \\
\left(\mathrm{cm}^{3} / \mathrm{cm}^{3}\right)\end{array}$ & $\begin{array}{l}\text { Particle } \\
\text { Density } \\
\left(\text { g/cm } / \mathrm{cm}^{3}\right)\end{array}$ & $\begin{array}{c}\text { Grav. } \\
\text { Water } \\
\text { Content } \\
(\mathbf{g} / \mathbf{g})\end{array}$ & $\begin{array}{c}\text { Vol. } \\
\text { Water } \\
\text { Content } \\
\left(\mathrm{cm}^{3} / \mathrm{cm}^{3}\right)\end{array}$ & $\begin{array}{l}\text { Relative } \\
\text { Satn. }\end{array}$ \\
\hline 1986.8 & 1.81 & 0.268 & 2.48 & 0.148 & 0.268 & 0.997 & 1.79 & 0.290 & 2.52 & 0.162 & 0.289 & 0.998 \\
\hline 1989.6 & 1.78 & 0.282 & 2.48 & 0.158 & 0.281 & 0.997 & 1.76 & 0.303 & 2.52 & 0.172 & 0.303 & 0.997 \\
\hline 1993.0 & 1.80 & 0.268 & 2.45 & 0.146 & 0.262 & 0.977 & 1.77 & 0.292 & 2.50 & 0.162 & 0.286 & 0.979 \\
\hline 1996.3 & 1.81 & 0.261 & 2.45 & 0.143 & 0.258 & 0.988 & 1.79 & 0.279 & 2.48 & 0.154 & 0.275 & 0.988 \\
\hline 1999.0 & 1.80 & 0.265 & 2.44 & 0.145 & 0.260 & 0.982 & 1.78 & 0.283 & 2.48 & 0.157 & 0.278 & 0.983 \\
\hline 2002.3 & 1.84 & 0.240 & 2.41 & 0.127 & 0.233 & 0.971 & 1.79 & 0.286 & 2.51 & 0.156 & 0.279 & 0.975 \\
\hline 2005.0 & 1.83 & 0.234 & 2.39 & 0.124 & 0.227 & 0.969 & 1.79 & 0.274 & 2.47 & 0.149 & 0.267 & 0.974 \\
\hline 2007.8 & 1.84 & 0.222 & 2.37 & 0.122 & 0.224 & 1.009 & 1.77 & 0.295 & 2.51 & 0.168 & 0.297 & 1.007 \\
\hline 2010.6 & 1.80 & 0.228 & 2.33 & 0.120 & 0.217 & 0.952 & 1.73 & 0.294 & 2.45 & 0.163 & 0.283 & 0.963 \\
\hline 2013.8 & 1.74 & 0.252 & 2.33 & 0.140 & 0.244 & 0.967 & 1.67 & 0.321 & 2.46 & 0.187 & 0.312 & 0.974 \\
\hline 2016.8 & 1.88 & 0.189 & 2.32 & 0.098 & 0.184 & 0.973 & 1.79 & 0.280 & 2.48 & 0.154 & 0.275 & 0.982 \\
\hline 2019.8 & 1.73 & 0.253 & 2.31 & 0.141 & 0.243 & 0.962 & 1.66 & 0.320 & 2.44 & 0.187 & 0.310 & 0.970 \\
\hline 2022.9 & 1.78 & 0.231 & 2.31 & 0.126 & 0.223 & 0.967 & 1.70 & 0.303 & 2.45 & 0.174 & 0.296 & 0.975 \\
\hline 2025.7 & 1.68 & 0.273 & 2.32 & 0.161 & 0.271 & 0.994 & 1.62 & 0.339 & 2.45 & 0.209 & 0.338 & 0.995 \\
\hline 2028.7 & 1.81 & 0.221 & 2.32 & 0.120 & 0.217 & 0.983 & 1.73 & 0.296 & 2.46 & 0.169 & 0.293 & 0.987 \\
\hline 2031.9 & 1.79 & 0.226 & 2.31 & 0.115 & 0.207 & 0.917 & 1.72 & 0.297 & 2.45 & 0.162 & 0.279 & 0.937 \\
\hline 2035.4 & 1.74 & 0.244 & 2.31 & 0.135 & 0.236 & 0.970 & 1.67 & 0.314 & 2.44 & 0.183 & 0.307 & 0.977 \\
\hline 2038.1 & 1.69 & 0.271 & 2.32 & 0.157 & 0.265 & 0.977 & 1.62 & 0.339 & 2.45 & 0.205 & 0.333 & 0.982 \\
\hline 2041.2 & 1.71 & 0.272 & 2.34 & 0.145 & 0.248 & 0.910 & 1.64 & 0.335 & 2.47 & 0.189 & 0.311 & 0.927 \\
\hline 2044.0 & 1.77 & 0.236 & 2.32 & 0.131 & 0.231 & 0.980 & 1.70 & 0.304 & 2.45 & 0.176 & 0.299 & 0.984 \\
\hline 2047.3 & 1.70 & 0.262 & 2.31 & 0.151 & 0.258 & 0.984 & 1.64 & 0.332 & 2.45 & 0.200 & 0.327 & 0.987 \\
\hline 2050.0 & 1.72 & 0.255 & 2.31 & 0.140 & 0.242 & 0.949 & 1.65 & 0.324 & 2.45 & 0.188 & 0.311 & 0.960 \\
\hline 2053.0 & 1.73 & 0.246 & 2.30 & 0.136 & 0.236 & 0.960 & 1.66 & 0.316 & 2.43 & 0.184 & 0.306 & 0.969 \\
\hline 2056.0 & 1.73 & 0.247 & 2.29 & 0.139 & 0.241 & 0.977 & 1.66 & 0.318 & 2.43 & 0.189 & 0.313 & 0.982 \\
\hline 2058.9 & 1.75 & 0.243 & 2.31 & 0.136 & 0.237 & 0.976 & 1.67 & 0.319 & 2.45 & 0.187 & 0.313 & 0.982 \\
\hline 2062.0 & 1.63 & 0.293 & 2.30 & 0.188 & 0.306 & 1.043 & 1.55 & 0.368 & 2.46 & 0.245 & 0.380 & 1.034 \\
\hline 2065.0 & 1.70 & 0.261 & 2.31 & 0.151 & 0.257 & 0.984 & 1.63 & 0.336 & 2.46 & 0.204 & 0.332 & 0.988 \\
\hline 2067.8 & 1.68 & 0.273 & 2.30 & 0.159 & 0.266 & 0.975 & 1.60 & 0.345 & 2.45 & 0.211 & 0.338 & 0.980 \\
\hline 2070.8 & 1.70 & 0.264 & 2.30 & 0.151 & 0.256 & 0.971 & 1.62 & 0.336 & 2.45 & 0.202 & 0.329 & 0.977 \\
\hline 2074.0 & 1.71 & 0.257 & 2.30 & 0.146 & 0.250 & 0.973 & 1.63 & 0.331 & 2.44 & 0.198 & 0.324 & 0.979 \\
\hline 2077.0 & 1.75 & 0.241 & 2.30 & 0.135 & 0.235 & 0.973 & 1.67 & 0.316 & 2.44 & 0.185 & 0.310 & 0.980 \\
\hline
\end{tabular}


Table G-1: Laboratory Material Properties and Water Contents Measured on Core Samples from Drill Hole USW SD-9 (Continued)

[Measurements reported by L.E. Flint, U.S. Geological Survey Hydrologic Research Facility; DTN No. GS950308312231.004. J. Curtis and C. Vidano, analysts. Sample number consists of "SD9-" plus depth in feet]

\begin{tabular}{|c|c|c|c|c|c|c|c|c|c|c|c|c|}
\hline \multirow[b]{2}{*}{$\begin{array}{l}\text { Depth } \\
\text { (feet) }\end{array}$} & \multicolumn{6}{|c|}{ Relative Humidity Oven Dried } & \multicolumn{6}{|c|}{$105^{\circ} \mathrm{C}$ Oven-Dried } \\
\hline & $\begin{array}{l}\text { Dry Bulk } \\
\text { Density } \\
\text { (g/cm³) }\end{array}$ & $\begin{array}{l}\text { Porosity } \\
\left(\mathrm{cm}^{3} / \mathrm{cm}^{3}\right)\end{array}$ & $\begin{array}{l}\text { Particle } \\
\text { Density } \\
\left(\mathrm{g} / \mathrm{cm}^{3}\right)\end{array}$ & $\begin{array}{l}\text { Grav. } \\
\text { Water } \\
\text { Content } \\
\text { (g/g) }\end{array}$ & $\begin{array}{c}\text { Vol. } \\
\text { Water } \\
\text { Content } \\
\left(\mathrm{cm}^{3} / \mathrm{cm}^{3}\right)\end{array}$ & $\begin{array}{c}\text { Relative } \\
\text { Satn. }\end{array}$ & $\begin{array}{l}\text { Dry Bulk } \\
\text { Density } \\
\left(\mathrm{g} / \mathrm{cm}^{3}\right)\end{array}$ & $\begin{array}{l}\text { Porosity } \\
\left(\mathrm{cm}^{3} / \mathrm{cm}^{3}\right)\end{array}$ & $\begin{array}{l}\text { Particle } \\
\text { Density } \\
\text { (g/cm })\end{array}$ & $\begin{array}{c}\text { Grav. } \\
\text { Water } \\
\text { Content } \\
\text { (g/g) }\end{array}$ & $\begin{array}{c}\text { Vol. } \\
\text { Water } \\
\text { Content } \\
\left(\mathrm{cm}^{3} / \mathrm{cm}^{3}\right)\end{array}$ & $\begin{array}{c}\text { Relative } \\
\text { Satn. }\end{array}$ \\
\hline 2080.0 & 1.78 & 0.223 & 2.29 & 0.127 & 0.226 & 1.010 & 1.70 & 0.301 & 2.43 & 0.178 & 0.303 & 1.008 \\
\hline 2083.0 & 1.78 & 0.224 & 2.29 & 0.123 & 0.219 & 0.979 & 1.70 & 0.300 & 2.43 & 0.173 & 0.295 & 0.984 \\
\hline 2085.7 & 1.76 & 0.234 & 2.29 & 0.131 & 0.230 & 0.985 & 1.68 & 0.308 & 2.43 & 0.181 & 0.305 & 0.988 \\
\hline 2089.2 & 1.75 & 0.235 & 2.28 & 0.131 & 0.230 & 0.980 & 1.67 & 0.311 & 2.43 & 0.183 & 0.307 & 0.985 \\
\hline 2092.1 & 1.77 & 0.227 & 2.29 & 0.126 & 0.222 & 0.981 & 1.69 & 0.307 & 2.44 & 0.179 & 0.303 & 0.986 \\
\hline 2094.9 & 1.79 & 0.216 & 2.29 & 0.117 & 0.210 & 0.973 & 1.72 & 0.293 & 2.43 & 0.167 & 0.287 & 0.980 \\
\hline 2098.0 & 1.81 & 0.204 & 2.27 & 0.115 & 0.207 & 1.019 & 1.72 & 0.292 & 2.43 & 0.172 & 0.296 & 1.013 \\
\hline 2101.2 & 1.81 & 0.210 & 2.30 & 0.112 & 0.204 & 0.970 & 1.73 & 0.291 & 2.44 & 0.165 & 0.285 & 0.979 \\
\hline 2103.5 & 1.83 & 0.178 & 2.22 & 0.095 & 0.174 & 0.981 & 1.74 & 0.263 & 2.36 & 0.149 & 0.259 & 0.987 \\
\hline 2106.6 & 1.80 & 0.198 & 2.24 & 0.110 & 0.198 & 0.998 & 1.72 & 0.281 & 2.39 & 0.163 & 0.280 & 0.999 \\
\hline 2109.6 & 1.81 & 0.194 & 2.25 & 0.106 & 0.191 & 0.988 & 1.72 & 0.280 & 2.40 & 0.161 & 0.278 & 0.991 \\
\hline 2113.1 & 1.81 & 0.189 & 2.24 & 0.104 & 0.189 & 1.000 & 1.73 & 0.275 & 2.38 & 0.159 & 0.275 & 1.000 \\
\hline 2116.2 & 1.79 & 0.205 & 2.25 & 0.114 & 0.203 & 0.988 & 1.71 & 0.287 & 2.39 & 0.167 & 0.285 & 0.991 \\
\hline 2118.9 & 1.81 & 0.184 & 2.22 & 0.099 & 0.180 & 0.979 & 1.72 & 0.270 & 2.36 & 0.154 & 0.266 & 0.986 \\
\hline 2121.5 & 1.67 & 0.260 & 2.26 & 0.153 & 0.256 & 0.982 & 1.59 & 0.341 & 2.41 & 0.212 & 0.337 & 0.986 \\
\hline 2124.4 & 1.76 & 0.213 & 2.23 & 0.119 & 0.208 & 0.981 & 1.68 & 0.296 & 2.38 & 0.174 & 0.292 & 0.986 \\
\hline 2127.8 & 1.75 & 0.221 & 2.25 & 0.126 & 0.220 & 0.993 & 1.67 & 0.302 & 2.39 & 0.180 & 0.300 & 0.995 \\
\hline 2131.0 & 1.78 & 0.203 & 2.23 & 0.112 & 0.200 & 0.986 & 1.69 & 0.292 & 2.39 & 0.171 & 0.290 & 0.991 \\
\hline 2133.9 & 1.76 & 0.214 & 2.24 & 0.120 & 0.210 & 0.981 & 1.68 & 0.296 & 2.38 & 0.174 & 0.292 & 0.986 \\
\hline 2137.1 & 1.82 & 0.187 & 2.24 & 0.103 & 0.188 & 1.002 & 1.74 & 0.271 & 2.38 & 0.157 & 0.272 & 1.001 \\
\hline 2140.0 & 1.77 & 0.204 & 2.22 & 0.112 & 0.198 & 0.971 & 1.68 & 0.290 & 2.37 & 0.169 & 0.285 & 0.980 \\
\hline 2143.0 & 1.82 & 0.184 & 2.23 & 0.099 & 0.180 & 0.980 & 1.73 & 0.272 & 2.38 & 0.155 & 0.269 & 0.986 \\
\hline 2146.0 & 1.79 & 0.207 & 2.26 & 0.112 & 0.201 & 0.972 & 1.71 & 0.289 & 2.41 & 0.165 & 0.283 & 0.980 \\
\hline 2149.0 & 1.72 & 0.231 & 2.24 & 0.128 & 0.221 & 0.957 & 1.64 & 0.310 & 2.38 & 0.183 & 0.301 & 0.968 \\
\hline 2151.8 & 1.75 & 0.225 & 2.26 & 0.127 & 0.222 & 0.990 & 1.68 & 0.302 & 2.40 & 0.179 & 0.299 & 0.992 \\
\hline 2155.0 & 1.77 & 0.211 & 2.25 & 0.119 & 0.210 & 0.998 & 1.70 & 0.289 & 2.39 & 0.171 & 0.289 & 0.999 \\
\hline 2157.8 & 1.69 & 0.241 & 2.23 & 0.140 & 0.237 & 0.984 & 1.61 & 0.325 & 2.38 & 0.200 & 0.321 & 0.988 \\
\hline 2161.0 & 1.77 & 0.211 & 2.25 & 0.118 & 0.209 & 0.992 & 1.69 & 0.293 & 2.39 & 0.172 & 0.291 & 0.994 \\
\hline 2164.0 & 1.77 & 0.215 & 2.25 & 0.121 & 0.214 & 0.996 & 1.68 & 0.298 & 2.40 & 0.176 & 0.297 & 0.997 \\
\hline 2166.8 & 1.66 & 0.255 & 2.23 & 0.152 & 0.253 & 0.992 & 1.58 & 0.338 & 2.38 & 0.213 & 0.336 & 0.994 \\
\hline 2170.0 & 1.68 & 0.249 & 2.24 & 0.147 & 0.248 & 0.995 & 1.60 & 0.332 & 2.40 & 0.207 & 0.331 & 0.996 \\
\hline
\end{tabular}


Table G-1: Laboratory Material Properties and Water Contents Measured on Core Samples from Drill Hole USW SD-9 (Continued)

[Measurements reported by L.E. Flint, U.S. Geological Survey Hydrologic Research Facility; DTN No. GS950308312231.004. J. Curtis and C. Vidano, analysts. Sample number consists of "SD9-" plus depth in feet]

\begin{tabular}{|c|c|c|c|c|c|c|c|c|c|c|c|c|}
\hline \multirow[b]{2}{*}{$\begin{array}{l}\text { Depth } \\
\text { (feet) }\end{array}$} & \multicolumn{6}{|c|}{ Relative Humidity Oven Dried } & \multicolumn{6}{|c|}{$105^{\circ} \mathrm{C}$ Oven-Dried } \\
\hline & $\begin{array}{c}\text { Dry Bulk } \\
\text { Density } \\
\text { (g/cm })\end{array}$ & $\begin{array}{l}\text { Porosity } \\
\left(\mathrm{cm}^{3} / \mathrm{cm}^{3}\right)\end{array}$ & $\begin{array}{l}\text { Particle } \\
\text { Density } \\
\text { (g/cm })\end{array}$ & $\begin{array}{c}\text { Grav. } \\
\text { Water } \\
\text { Content } \\
(\mathbf{g} / \mathbf{g})\end{array}$ & $\begin{array}{c}\text { Vol. } \\
\text { Water } \\
\text { Content } \\
\left(\mathrm{cm}^{3} / \mathrm{cm}^{3}\right)\end{array}$ & $\begin{array}{c}\text { Relative } \\
\text { Satn. }\end{array}$ & $\begin{array}{l}\text { Dry Bulk } \\
\text { Density } \\
\text { (g/cm })\end{array}$ & $\begin{array}{l}\text { Porosity } \\
\left(\mathrm{cm}^{3} / \mathrm{cm}^{3}\right)\end{array}$ & $\begin{array}{l}\text { Particle } \\
\text { Density } \\
\text { (g/cm })\end{array}$ & $\begin{array}{c}\text { Grav. } \\
\text { Water } \\
\text { Content } \\
(g / g)\end{array}$ & $\begin{array}{c}\text { Vol. } \\
\text { Water } \\
\text { Content } \\
\left(\mathrm{cm}^{3} / \mathrm{cm}^{3}\right)\end{array}$ & $\begin{array}{c}\text { Relative } \\
\text { Satn. }\end{array}$ \\
\hline 2172.8 & 1.78 & 0.197 & 2.22 & 0.110 & 0.195 & 0.989 & 1.70 & 0.281 & 2.36 & 0.164 & 0.278 & 0.992 \\
\hline 2175.9 & 1.78 & 0.201 & 2.23 & 0.112 & 0.200 & 0.993 & 1.70 & 0.285 & 2.38 & 0.167 & 0.284 & 0.995 \\
\hline 2179.0 & 1.74 & 0.231 & 2.27 & 0.130 & 0.226 & 0.979 & 1.66 & 0.312 & 2.42 & 0.184 & 0.307 & 0.984 \\
\hline 2181.7 & 1.74 & 0.229 & 2.25 & 0.131 & 0.227 & 0.991 & 1.66 & 0.307 & 2.39 & 0.184 & 0.305 & 0.993 \\
\hline 2185.0 & 1.77 & 0.210 & 2.24 & 0.118 & 0.209 & 0.997 & 1.69 & 0.291 & 2.38 & 0.172 & 0.290 & 0.998 \\
\hline 2187.6 & 1.80 & 0.197 & 2.24 & 0.108 & 0.195 & 0.989 & 1.72 & 0.278 & 2.38 & 0.161 & 0.276 & 0.992 \\
\hline 2190.9 & 1.78 & 0.199 & 2.23 & 0.110 & 0.196 & 0.983 & 1.70 & 0.282 & 2.37 & 0.163 & 0.278 & 0.988 \\
\hline 2193.7 & 1.74 & 0.229 & 2.26 & 0.130 & 0.227 & 0.990 & 1.67 & 0.305 & 2.40 & 0.181 & 0.303 & 0.993 \\
\hline 2196.9 & 1.77 & 0.215 & 2.25 & 0.120 & 0.212 & 0.988 & 1.69 & 0.294 & 2.39 & 0.172 & 0.291 & 0.991 \\
\hline 2199.9 & 1.77 & 0.215 & 2.25 & 0.118 & 0.209 & 0.970 & 1.68 & 0.298 & 2.40 & 0.173 & 0.292 & 0.978 \\
\hline 2202.6 & 1.77 & 0.222 & 2.27 & 0.125 & 0.222 & 0.999 & 1.70 & 0.288 & 2.39 & 0.169 & 0.288 & 0.999 \\
\hline 2206.0 & 1.78 & 0.206 & 2.24 & 0.116 & 0.206 & 1.000 & 1.71 & 0.275 & 2.36 & 0.161 & 0.275 & 1.000 \\
\hline 2208.8 & 1.75 & 0.221 & 2.25 & 0.125 & 0.219 & 0.990 & 1.69 & 0.287 & 2.37 & 0.169 & 0.285 & 0.992 \\
\hline 2211.9 & 1.77 & 0.214 & 2.25 & 0.117 & 0.207 & 0.966 & 1.70 & 0.283 & 2.37 & 0.162 & 0.275 & 0.974 \\
\hline 2214.6 & 1.77 & 0.211 & 2.25 & 0.119 & 0.211 & 0.999 & 1.70 & 0.283 & 2.37 & 0.166 & 0.283 & 0.999 \\
\hline 2217.9 & 1.81 & 0.188 & 2.22 & 0.102 & 0.184 & 0.983 & 1.73 & 0.267 & 2.36 & 0.153 & 0.264 & 0.988 \\
\hline 2221.1 & 1.81 & 0.180 & 2.21 & 0.099 & 0.179 & 0.995 & 1.73 & 0.264 & 2.35 & 0.152 & 0.263 & 0.996 \\
\hline
\end{tabular}


Table G-2: Porosity and Saturated Hydraulic Conductivity Values Measured on Core Samples from Drill Hole USW SD-9

[Measurements reported by L.E. Flint, U.S. Geological Survey Hydrologic Research Facility; DTN No. GS950608312231.006. Ksat - saturated hydraulic conductivity.

Sample number consists of "SD9-" plus depth in feet. nf-no measurable flow]

\begin{tabular}{|c|c|c|c|}
\hline $\begin{array}{l}\text { Depth } \\
\text { (feet) }\end{array}$ & $\begin{array}{l}\text { Porosity } \\
\left(\mathrm{cm}^{3} / \mathrm{cm}^{3}\right)\end{array}$ & $\begin{array}{c}\text { Ksat } \\
(\mathrm{m} / \mathrm{sec})\end{array}$ & Notes \\
\hline 56.9 & 0.177 & $8.63 \mathrm{E}-11$ & \\
\hline 61.8 & 0.171 & $1.06 \mathrm{E}-11$ & \\
\hline 71.3 & 0.210 & $1.85 \mathrm{E}-10$ & (a) \\
\hline 77.2 & 0.270 & $9.60 \mathrm{E}-09$ & \\
\hline 83.1 & 0.357 & 8.79E-07 & \\
\hline 88.6 & 0.359 & $4.87 \mathrm{E}-07$ & \\
\hline 100.7 & 0.379 & $3.66 \mathrm{E}-07$ & \\
\hline 107.5 & 0.310 & $2.01 \mathrm{E}-07$ & \\
\hline 113.4 & 0.281 & 5.87E-08 & \\
\hline 116.0 & 0.265 & $2.45 \mathrm{E}-08$ & \\
\hline 122.3 & 0.297 & 4.32E-08 & \\
\hline 133.0 & 0.346 & $1.02 \mathrm{E}-06$ & \\
\hline 137.6 & 0.333 & 8.19E-07 & \\
\hline 151.7 & 0.324 & $1.20 \mathrm{E}-06$ & \\
\hline 154.5 & 0.403 & $1.41 \mathrm{E}-06$ & \\
\hline 160.9 & 0.465 & $1.74 \mathrm{E}-06$ & \\
\hline 173.0 & 0.426 & 1.61E-06 & \\
\hline 209.5 & 0.489 & $1.74 \mathrm{E}-06$ & \\
\hline 217.3 & 0.438 & 7.62E-07 & \\
\hline 232.3 & 0.483 & $5.06 \mathrm{E}-07$ & \\
\hline 238.1 & 0.592 & $1.87 \mathrm{E}-06$ & \\
\hline 246.0 & 0.581 & $7.46 \mathrm{E}-06$ & \\
\hline 247.4 & 0.491 & $5.68 \mathrm{E}-06$ & \\
\hline 259.7 & 0.538 & 2.19E-06 & \\
\hline 278.3 & 0.016 & 2.33E-08 & (b) \\
\hline 287.1 & 0.041 & nf & \\
\hline 291.1 & 0.030 & nf & \\
\hline 308.3 & 0.140 & $4.77 \mathrm{E}-10$ & \\
\hline 323.2 & 0.133 & $1.83 \mathrm{E}-09$ & \\
\hline 335.6 & 0.117 & $9.43 \mathrm{E}-10$ & \\
\hline 359.1 & 0.109 & $2.04 \mathrm{E}-09$ & \\
\hline 385.6 & 0.124 & $1.99 \mathrm{E}-08$ & \\
\hline
\end{tabular}

Table G-2: Porosity and Saturated Hydraulic Conductivity Values Measured on Core Samples from Drill Hole USW SD-9 (Continued)

[Measurements reported by L.E. Flint, U.S. Geological Survey Hydrologic Research Facility; DTN No. GS950608312231.006. Ksat - saturated hydraulic conductivity.

Sample number consists of "SD9-" plus depth in feet. nf-no measurable flow]

\begin{tabular}{|c|c|c|c|}
\hline $\begin{array}{l}\text { Depth } \\
\text { (feet) }\end{array}$ & $\begin{array}{l}\text { Porosity } \\
\left(\mathrm{cm}^{3} / \mathrm{cm}^{3}\right)\end{array}$ & $\begin{array}{c}\text { Ksat } \\
(\mathrm{m} / \mathrm{sec})\end{array}$ & Notes \\
\hline 388.1 & 0.143 & $5.04 \mathrm{E}-09$ & \\
\hline 395.4 & 0.125 & $2.30 \mathrm{E}-10$ & \\
\hline 405.1 & 0.098 & $8.30 \mathrm{E}-11$ & \\
\hline 415.0 & 0.114 & $6.14 \mathrm{E}-11$ & \\
\hline 429.8 & 0.091 & $4.22 \mathrm{E}-09$ & (b) \\
\hline 439.5 & 0.082 & nf & \\
\hline 455.0 & 0.096 & $\mathrm{nf}$ & \\
\hline 479.1 & 0.094 & nf & \\
\hline 512.4 & 0.146 & $1.07 \mathrm{E}-10$ & \\
\hline 552.6 & 0.115 & $1.31 \mathrm{E}-10$ & \\
\hline 577.6 & 0.114 & $1.17 \mathrm{E}-10$ & \\
\hline 599.2 & 0.132 & $6.82 \mathrm{E}-11$ & \\
\hline 627.0 & 0.130 & $3.39 \mathrm{E}-10$ & \\
\hline 650.1 & 0.108 & 2.07E-09 & \\
\hline 658.2 & 0.094 & $3.87 \mathrm{E}-11$ & \\
\hline 672.2 & 0.117 & $3.65 \mathrm{E}-11$ & \\
\hline 682.9 & 0.145 & $8.53 \mathrm{E}-11$ & \\
\hline 697.4 & 0.110 & $7.12 \mathrm{E}-11$ & \\
\hline 707.6 & 0.105 & $2.34 \mathrm{E}-11$ & \\
\hline 721.2 & 0.090 & $1.71 \mathrm{E}-11$ & \\
\hline 730.8 & 0.094 & nf & \\
\hline 746.9 & 0.073 & nf & \\
\hline 777.2 & 0.081 & $\mathrm{nf}$ & \\
\hline 798.0 & 0.112 & 8.31E-10 & (c) \\
\hline 818.2 & 0.069 & nf & \\
\hline 834.3 & 0.086 & nf & \\
\hline 849.8 & 0.186 & $3.99 \mathrm{E}-09$ & \\
\hline 865.5 & 0.092 & $6.71 \mathrm{E}-11$ & \\
\hline 899.9 & 0.085 & $5.22 \mathrm{E}-11$ & \\
\hline 944.9 & 0.087 & $5.43 \mathrm{E}-11$ & \\
\hline 975.8 & 0.070 & $1.18 \mathrm{E}-11$ & \\
\hline
\end{tabular}


Table G-2: Porosity and Saturated Hydraulic Conductivity Values Measured on Core Samples from Drill Hole USW SD-9 (Continued) [Measurements reported by L.E. Flint, U.S. Geological Survey Hydrologic Research Facility; DTN No. GS950608312231.006. Ksat - saturated hydraulic conductivity. Sample number consists of "SD9-" plus depth in feet. nf-no measurable flow]

\begin{tabular}{|c|c|c|c|}
\hline $\begin{array}{l}\text { Depth } \\
\text { (feet) }\end{array}$ & $\begin{array}{l}\text { Porosity } \\
\left(\mathrm{cm}^{3} / \mathrm{cm}^{3}\right)\end{array}$ & $\begin{array}{c}\text { Ksat } \\
(\mathrm{m} / \mathrm{sec})\end{array}$ & Notes \\
\hline 1012.6 & 0.092 & $6.94 \mathrm{E}-11$ & \\
\hline 1035.5 & 0.085 & nf & \\
\hline 1086.0 & 0.090 & nf & \\
\hline 1105.9 & 0.104 & $3.94 \mathrm{E}-11$ & \\
\hline 1142.2 & 0.109 & $4.38 \mathrm{E}-10$ & \\
\hline 1166.2 & 0.085 & $\mathrm{nf}$ & \\
\hline 1200.5 & 0.082 & $\mathrm{nf}$ & \\
\hline 1224.6 & 0.092 & $8.08 \mathrm{E}-09$ & (d) \\
\hline 1256.5 & 0.087 & nf & \\
\hline 1285.0 & 0.097 & $5.61 \mathrm{E}-10$ & (d) \\
\hline 1308.1 & 0.083 & $\mathrm{nf}$ & \\
\hline 1335.3 & 0.067 & $\mathrm{nf}$ & \\
\hline 1440.5 & 0.139 & $1.04 \mathrm{E}-10$ & \\
\hline 1444.7 & 0.277 & 8.70E-08 & \\
\hline 1459.7 & 0.173 & $\mathrm{nf}$ & \\
\hline 1466.7 & 0.215 & nf & \\
\hline 1473.3 & 0.178 & nf & \\
\hline 1478.3 & 0.118 & $\mathrm{nf}$ & \\
\hline 1501.8 & 0.266 & $6.57 \mathrm{E}-11$ & \\
\hline 1488.0 & 0.325 & nf & \\
\hline 1513.6 & 0.213 & $1.78 \mathrm{E}-11$ & \\
\hline 1526.7 & 0.267 & $\mathrm{nf}$ & \\
\hline 1547.9 & 0.248 & $2.12 \mathrm{E}-11$ & \\
\hline 1569.3 & 0.245 & $7.23 \mathrm{E}-12$ & \\
\hline 1583.5 & 0.226 & $1.27 \mathrm{E}-11$ & \\
\hline 1617.8 & 0.278 & $3.00 \mathrm{E}-11$ & \\
\hline 1643.9 & 0.258 & $1.44 \mathrm{E}-11$ & \\
\hline 1671.9 & 0.249 & $5.68 \mathrm{E}-11$ & \\
\hline 1698.4 & 0.335 & $8.86 \mathrm{E}-11$ & \\
\hline 1720.0 & 0.229 & nf & \\
\hline 1768.1 & 0.216 & nf & \\
\hline
\end{tabular}

Table G-2: Porosity and Saturated Hydraulic Conductivity Values Measured on Core Samples from Drill Hole USW SD-9 (Continued) [Measurements reported by L.E. Flint, U.S. Geological Survey Hydrologic Research Facility; DTN No. GS950608312231.006. Ksat - saturated hydraulic conductivity. Sample number consists of "SD9-" plus depth in feet. nf-no measurable flow]

\begin{tabular}{lccc}
\hline $\begin{array}{l}\text { Depth } \\
\text { (feet) }\end{array}$ & $\begin{array}{c}\text { Porosity } \\
\left(\mathrm{cm}^{3} / \mathrm{cm}^{3}\right)\end{array}$ & $\begin{array}{c}\text { Ksat } \\
(\mathrm{m} / \mathrm{sec})\end{array}$ & Notes \\
\hline 1789.0 & 0.177 & nf & \\
1811.2 & 0.170 & $8.88 \mathrm{E}-11$ & $(\mathrm{e})$ \\
1837.2 & 0.198 & nf & \\
1851.0 & 0.303 & $2.45 \mathrm{E}-10$ & \\
1860.8 & 0.261 & $5.94 \mathrm{E}-11$ & \\
1896.1 & 0.333 & $1.16 \mathrm{E}-07$ & \\
1927.0 & 0.314 & $3.04 \mathrm{E}-09$ & \\
1956.5 & 0.252 & $2.05 \mathrm{E}-09$ & \\
1977.1 & 0.212 & $1.08 \mathrm{E}-10$ & \\
1989.8 & 0.294 & $4.40 \mathrm{E}-10$ & \\
2017.0 & 0.260 & $5.37 \mathrm{E}-11$ & \\
2040.6 & 0.247 & $3.43 \mathrm{E}-11$ & \\
2077.2 & 0.233 & $1.90 \mathrm{E}-11$ & \\
2095.1 & 0.206 & $1.92 \mathrm{E}-11$ & \\
2118.4 & 0.173 & nf & \\
2145.5 & 0.214 & $1.02 \mathrm{E}-11$ & \\
2158.0 & 0.216 & $4.83 \mathrm{E}-11$ & \\
2179.2 & 0.222 & $8.79 \mathrm{E}-11$ & \\
2206.2 & 0.217 & $1.34 \mathrm{E}-10$ & \\
\hline
\end{tabular}

a. Sample thinner than specification; Ksat may not be valid

b. Sample exhibited high flow but low porosity; pumice or lithophysae may be conducting flow

c. Anomalously high porosity sample

d. Sample is fractured; Ksat is probably too high for matrix

e. Anomalously low flow for high-porosity sample 
Yucca Mountain Site Characterization Project

SAND96-2030 Distribution List

D. A. Dreyfus (RW-1)

Director

OCRWM

US Department of Energy

1000 Independence Avenue SW

Washington, DC 20585

1

L. H. Barrett (RW-2)

Acting Deputy Director

OCRWM

US Department of Energy

1000 Independence Avenue SW

Washington, DC 20585

S. Rousso (RW-40)

Office of Storage and Transportation

OCRWM

US Department of Energy

1000 Independence Avenue SW

Washington, DC 20585

1 R. A. Milner (RW-30)

Office of Program Management and Integration

OCRWM

US Department of Energy

1000 Independence Avenue SW

Washington, DC 20585

1 D. R. Elle, Director

Environmental Protection Division

DOE Nevada Field Office

US Department of Energy

P.O. Box 98518

Las Vegas, NV 89193-8518

1 T. Wood (RW-14)

Contract Management Division

OCRWM

US Department of Energy

1000 Independence Avenue SW

Washington, DC 20585

5 Victoria F. Reich, Librarian

Nuclear Waste Technical Review Board

1100 Wilson Blvd., Suite 910

Arlington, VA 22209

$5 \quad$ Wesley Barnes, Project Manager

Yucca Mountain Site Characterization Office

US Department of Energy

P.O. Box 98608--MS 523

Las Vegas, NV 89193-8608

1 Steve Hanauer (RW-2)

\section{OCRWM}

U. S. Department of Energy

1000 Independence Ave.

Washington, DC 20585
1 Director, Public Affairs Office

c/o Technical Information Resource Center

DOE Nevada Operations Office

US Department of Energy

P.O. Box 98518

Las Vegas, NV 89193-8518

10 Technical Information Officer

DOE Nevada Operations Office

US Department of Energy

P.O. Box 98518

Las Vegas, NV 89193-8518

1 J. R. Dyer, Deputy Project Manager

Yucca Mountain Site Characterization Office

US Department of Energy

P.O. Box 98608 -- MS 523

Las Vegas, NV 89193-88608

$5 \quad$ M.C. Tynan

U.S. Department of Energy

P. O. Box 98608; MS-523

Las Vegas, NV 87193-8608

1 Repository Licensing \& Quality

Assurance

Project Directorate

Division of Waste Management, MS T7J-9

US NRC

Washington, DC 20555

1

Senior Project Manager for Yucca

Mountain

Repository Project Branch

Division of Waste Management, MS T7J-9

US NRC

Washington, DC 20555

$5 \quad$ NRC Document Control Desk

Division of Waste Management, MS T7J-9

US NRC

Washington, DC 20555

1 Chad Glenn

NRC Site Representative

301 E Stewart Avenue, Room 203

Las Vegas, NV 89101

5

Center for Nuclear Waste

Regulatory Analyses

Southwest Research Institute

6220 Culebra Road

Drawer 28510

San Antonio, TX 78284

1

Robert L. Strickler

Vice President \& General Manager

TRW Environmental Safety Systems, Inc.

2650 Park Tower Dr.

Vienna, VA 22180 
101 Convention Center Drive Las Vegas, NV 89109

\section{3}

Chris Lewis

YMP Sample Management Facility

CWRMS M\&O; MS-719

101 Convention Center Drive

Las Vegas, NV 89109

1 Dale A. Engstrom

Spectra Research Institute

2201 Buena Vista, SE; Ste. 300

Albuquerque, NM 87106

$\begin{array}{lll} & \text { MS } & \\ 2 & 1330 & \begin{array}{l}\text { B. Pierson, 6811 } \\ \text { 10O/WBS123274/SAND95-2080/NQ }\end{array} \\ 20 & 1330 & \text { WMT Library, 6752 } \\ 5 & 1324 & \text { C.A. Rautman, 6115 } \\ 1 & 1324 & \text { S.A. McKenna, 6115 } \\ 1 & 1324 & \text { W.P. Zelinski, 6115 } \\ 1 & 1325 & \text { N.S. Brodsky, 6852 } \\ 1 & 1325 & \text { R.E. Finley, 6852 } \\ 1 & 1326 & \text { H.A. Dockery, 6851 } \\ 1 & 1326 & \text { S.J. Altman, 6851 } \\ 1 & 1326 & \text { B.W. Arnold, 6851 } \\ 1 & 1326 & \text { R.W. Barnard, 6851 } \\ 1 & 1326 & \text { G.E. Barr, 6851 } \\ 1 & 1326 & \text { N.D. Francis } \\ 1 & 1326 & \text { J.H. Gauthier } \\ 1 & 1326 & \text { M.L. Wilson } \\ 1 & 1325 & \text { L.S. Costin, 6852 } \\ 5 & 1399 & \text { C. Lum, 6853 } \\ 1 & & \\ 5 & 9018 & \text { Central Technical Files, 8523-2 } \\ 2 & 0899 & \text { Technical Library, 4414 } \\ & 0100 & \text { Review and Approval Desk, 7613-2 } \\ & & \text { For DOE/OSTI }\end{array}$

